\title{
VERHANDELINGEI
}

VAN HET KONINKLIJK INSTITUUT VOOR TAAL-, LAND- EN VOLKENKUNDE

\author{
DEEL XIV
}

\section{RAFFLES' IDEAS ON THE LAND RENT SYSTEM IN JAVA AND THE}

MACKENZIE LAND TENURE COMMISSION

BY

\author{
JOHN BASTIN
}

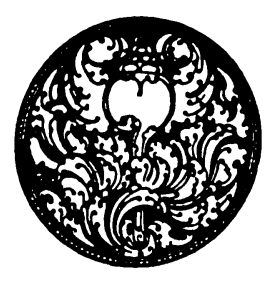

'S.GRAVENHAGE - MARTINUS NIJHOFF - 
John Bastin - 978-90-04-28636-8

Downloaded from Brill.com๑4/26/2023 $01: 25: 59 \mathrm{PM}$

via free access 
Contents . . . . . . . . . . . . . . . . . . . . . . . vii

Preface . . . . . . . . . . . . . . . . . . . . . . . ix

List of Abbreviations . . . . . . . . . . . . . . . . . . . xii

I LAND REVENUE IN BRITISH INDIA AND JAVA . . . . 1

Land Revenue in Bengal . . . . . . . . . . . . . . . 1

Munro and the Ryotwari System . . . . . . . . . . . . 5

Minto's support of Permanent Zamindari Settlements . . . . . 7

Munro and the victory of the Ryotwari System . . . . . . . 9

The Bengal Revenue System and Dirk van Hogendorp . . . . 11

II THE BEGINNINGS OF THE LAND RENT SYSTEM IN JAVA 15

Minto's Instructions on Land Reform . . . . . . . . . . 15

The Appointment of the Mackenzie Land Tenure Commission . . 18

The Early Meetings of the Mackenzie Commission . . . . . . 23

Raffles realizes that reform must proceed slowly . . . . . . . 27

Raffles recognizes Chinese proprietorship in the Oosthoek . . . 30

The first Land Settlement - Bantam . . . . . . . . . . 33

Crawfurd on the Sultan's Territories . . . . . . . . . . . 36

Raffles suggests the Bantam Settlement for the rest of Java . . . 39

Raffles informs Lord Minto about Land Reform . . . . . . . 40

Continuation of Contingents and Forced Deliveries . . . . . . 42

III IDEAS ON REFORM . . . . . . . . . . . . . . . 49

Hope, Muntinghe and Goldbach . . . . . . . . . . . . 49

Knops and Lawick van Pabst's Report "Java as it is, 8 as it may be" 55

Christiani's Advice . . . . . . . . . . . . . . . . . 61

Rothenbühler's Report . . . . . . . . . . . . . . . . 62

Mackenzie's Report . . . . . . . . . . . . . . . . . 68

The Mackenzie Commission and the Sale of Lands . . . . . . 70

IV THE SALE OF LANDS . . . . . . . . . . . . . . . 72

The Deteriorating Finances of Java . . . . . . . . . . . 72

The Lands Sold . . . . . . . . . . . . . . . . . . . 80

(a) The Batavian Regencies and Krawang . . . . . . 80

(b) Semarang . . . . . . . . . . . . . . . . 86

(c) Surabaya . . . . . . . . . . . . . . . . . . . . $\quad .88$

The Financial Results of the Sale . . . . . . . . . . . .88

The Question of Forced Services on the Private Estates . . . . 89

V THE EARLY LAND RENT SETTLEMENTS IN THE

TRANSFERRED DISTRIC'TS AND BANTAM 1812-1813 . . 93

The Transferred Districts . . . . . . . . . . . . . . . 94

Patjitan . . . . . . . . . . . . . . . . . . . 95

Kedu . . . . . . . . . . . . . . . . . . . . . . 99

Djapan . . . . . . . . . . . . . . . . . . . . . 101

Wirasaba . . . . . . . . . . . . . . . . . . . . 102

Djipang . . . . . . . . . . . . . . . . . . . . . 102

Wirosari . . . . . . . . . . . . . . . . . 103 
Page

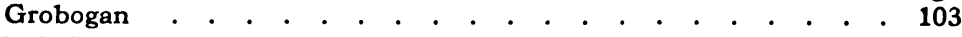

Pekalongan . . . . . . . . . . . . . . . . . . . . 104

Bantam . . . . . . . . . . . . . . . . . . . . 105

VI MINUTES AND REPORTS ON THE LAND RENT SYSTEM 1813113

Raffles' Minute of May 28, 1813 . . . . . . . . . . . . 115

Raffles' Minute of June 14, 1813 . . . . . . . . . . . . 116

Crawfurd's Report on Land Tenures . . . . . . . . . . . 118

Muntinghe raises objections . . . . . . . . . . . . . . 119

Raffles aware of objections . . . . . . . . . . . . . . 120

Mackenzie leaves Java, and the Land Tenure Commission ends

its work . . . . . . . . . . . . . . . . . . . . . 121

VII THE VILLAGE LAND RENT SETTLEMENTS OF 1813 . . . 127

Tjirebon . . . . . . . . . . . . . . . . . . . . . 127

Tegal, Brebes and Pemalang . . . . . . . . . . . . . . 131

Semarang, Kendal and Demak . . . . . . . . . . . . . 132

Djapara, Djuwana, Pati and Kudus . . . . . . . . . . . 134

Surabaya, Gresik, Sidayu, Lamongan, Bangil and Pasuruan . . . 136

Besuki, Probolinggo, Panarukan, Puger and Banjuwangi . . . . 137

Raffles reports on the introduction of the land rent system

throughout Java . . . . . . . . . . . . . . . . . . 143

VIII RAFFLES' CONVERSION TO THE RYOTWARI SYSTEM . . 146

Mackenzie's Influence on Raffles . . . . . . . . . . . . 149

Dirk van Hogendorp and Raffles . . . . . . . . . . . . 150

The Influence of Muntinghe on Raffles' Ideas . . . . . . . . 154

Raffles' Conversion to the Ryotwari System . . . . . . . . 155

IX THE LAND RENT ASSESSMENTS OF 1813 . . . . . . . 163

Tjirebon . . . . . . . . . . . . . . . . . . . . . 163

Tegal, Brebes and Pemalang . . . . . . . . . . . . . . 163

Pekalongan, Ulujami and Batang . . . . . . . . . . . . 164

Kedu . . . . . . . . . . . . . . . . . . . . . . 167

Grobogan, Djipang and Wirosari . . . . . . . . . . . . 169

Semarang, Kendal and Demak . . . . . . . . . . . . . 170

Pasuruan . . . . . . . . . . . . . . . . . . . . . 171

Besuki, Probolinggo, Fanarukan, Puger and Banjuwangi . . . . 173

Surabaya and Gresik . . . . . . . . . . . . . . . . 174

Rembang, Lasem and Tuban . . . . . . . . . . . . . . 174

Djapara, Djuwana, Pati and Kudus . . . . . . . . . . . 175

X IDEAS AND REACTIONS . . . . . . . . . . . . . . 177

Raffles' Revenue Instructions . . . . . . . . . . . . . 177

Bengal's reaction to Raffles' Reforms . . . . . . . . . . 179

Raffles defends the new System . . . . . . . . . . . . . 182

The Priangan System . . . . . . . . . . . . . . . . 184

BIBLIOGRAPHY . . . . . . . . . . . . . . . . 188 


\section{PREFACE}

This study was suggested by $\operatorname{Dr} H$. R. C. Wright's article "Muntinghe's Advice to Raffles on the Land Question in Java"." It does not pretend to be exhaustive. I have not examined the working of the land rent system during the British administration, ${ }^{2}$ nor, indeed, have I carried the story further than the early months of 1814. I hope that at some future date it may be possible to analyse the system during the years $1814-1816$. For that reason, I have not developed the theme, so ably stated by Professor D. $\mathbf{H}$. Burger, of the penetration of a money economy into the native society during Raffles' Government, ${ }^{3}$ nor have I examined Furnivall's related argument that the industrial position of England at the beginning of the 19th century necessitated an increase in the welfare and consuming power of the Javanese. ${ }^{4}$ The English land tax, ${ }^{5}$ the ideas of Adam Smith, Sir James Stuart, Sinclair and other Political Economists of the 18th century, and the pervasive humanitarian influence engendered by the writings of Montesquieu, Voltaire and Raynal, all properly fall within the scope of my subject. Yet I have treated none of these questions. I have merely examined the effect of local influences in Java upon the development of Raffles' thought

1 Bijd. T.L.V., (1952), Vol. 108, pp. 220-247.

2 The various reports of the Dutch Residents to the Commissioners-General in 1816 and 1817 have been published, and these give a valuable first-hand account of how the land rent system was functioning at the time of the Dutch restoration. Deventer, S. van, Bijdragen tot de kennis van het Landelijk Stelsel op Java, (1865-6), I, pp. 259 et seq. (Hereafter cited L.S.); Deventer, M. L. van, Het Nederlandsch Gezag over Java en Onderhoorigheden sedert 1811, (1891), I. (Hereafter cited N.G.). See also, Kemp, P. H. van der, Java's Landelijk Stelsel 1817-1819, (1916), for a detailed examination of the working of the system during the years immediately following the British administration, and Norman, H. D. Levyssohn, De Britische Heerschappij over Java en Onderhoorigheden, (1811-1816), (1857), pp. 182 et seq. for a good short account of the system during Raffles' period.

3 Burger, D. H., De Ontsluiting van Java's Binnenland voor het Wereld Verkeer, (1939), pp. 55 et seq.

4 Furnivall, J. S., Netherlands India, A Study of Plural Economy, (1944), 68.

5 A recent study which deals with this subject, Ward, W. R., The English Land Tax in the Eighteenth Century, (1953). 
- the discoveries made by the Mackenzie Commissioners regarding land tenures, and the theories propounded by certain Dutchmen for a reform in the colonial system during the first two years of British rule. These theories reflected, in general, the whole Van HogendorpNederburgh controversy of the previous decade.

Dutch historians have referred incidentally to the Mackenzie Commission, and have hinted at its importance. ${ }^{\theta}$ But these references have been vague, and sometimes astray. In the following pages, I have attempted to examine in some detail the results of the Commission's investigations into the land tenures of Java. In part, therefore, the study is a development of Van Vollenhoven's theme of the pioneering rôle played by Raffles, Muntinghe, Crawfurd and others in the discovery of the Adatrecht of Java. ${ }^{7}$

A word about money values, weights and measures. Three monetary terms have been employed in the text - Spanish dollars, Rix dollars (Rijksdaalders) and Java Rupees. The number of stivers in each, may be reckoned as 66,48 and 30 respectively. In some cases, which I have indicated, Sp. drs. have been calculated at the recognized Dutch rate of 64 stivers. Generally speaking, a Sp. dr. may be regarded as the equivalent of 5 English shillings in Raffles' time, and a Java Rupee as half a crown. Sp. drs. can be converted to J. Rs. by calculating 1,000 Sp. drs. as the equivalent of 2,200 J. Rs. Weights and measures are more difficult to standardize, and the reader should refer to Appendix $\mathbf{M}$ in Raffles' History of Java. ${ }^{8}$

For the sake of convenience, English plural forms of Javanese words have been used throughout, for example, Bekels, instead of Bekel's, sawahs, instead of sawah's, and so on. In some cases, I have retained the old English form, such as hamats instead of amet's, to avoid confusion.

Many people have helped me in the writing of this book. I am particularly indebted to the officers of the India Office Library, London; the Algemeen Rijksarchief, The Hague; and the University

6 Stapel, F. W., edit. Geschiedenis van Nederlandsch Indië, (1938-40), V, 116; Gelpke, J. H. F. Sollewijn, Gegevens voor een nieuwe LandrenteRegeling...., (1885), Introd. De Haan, F., Priangan, De Preanger-Regentschappen onder het Nederlandsch Bestuur tot 1811, (1910-12), II, Bijlage L, pp. 680 et seq. has published some material relating to the Commission.

7 Vollenhoven, C. van, De Ontdekking van het Adatrecht, (1928), pp. 19-34. See also "Raffles' Landrente en het Adatrecht", Het Adatrecht van Nederlandsch-Indië, (1918-33), III, pp. 554-8.

8 Vol. II, pp. cclviii-cclx. (Hereafter referred to as $H$. of J.) 
Library, Leiden. I wish to thank the Board of the Koninklijk Instituut voor Taal-, Land- en Volkenkunde for making the publication of this study possible, and the Netherlands Ministry of Education, Arts and Sciences, and the Trustees of the Services Canteens Trust Fund, Australia, for scholarships which have enabled me to study at Leiden. I offer my sincerest thanks to Professor Dr A. A. Cense, Professor Dr F. D. K. Bosch, Profeśsor Dr C. C. Berg, Professor Dr E. M. Uhlenbeck, Professor Dr V. E. Korn, Professor Dr Th. J. G. Locher, Dr H. J. de Graaf, Dr P. Voorhoeve and Mr F. J. J. Bezier. I should like to thank especially Professor Dr J. H. Boeke, Professor Dr W. Ph. Coolhaas, Professor V. T. Harlow and Miss Johanna Felhoen Kraal for much help and advice. Lastly, but by no means least, I thank my wife for her patience and understanding during the preparation and writing of this study.

J. B. 


\section{LIST OF ABBREVIATIONS}

\section{(a) PUBLISHED WORKS :}

Bijd. T.L.V. - Bijdragen tot de Taal-, Land- en Volkenkunde van NederlandschIndië, ('s-Gravenhage).

D.N.B. - Dictionary of National Biography, (London, 1893).

Eindresumé - Eindresumé Onderzoek naar de Rechten van den Inlander op den Grond op Java en Madoera, (Batavia, 1876-96), 3 vols.

H. of J. - Raffles, T. S., History of Java, (London, 1817), 2 vols.

Gillespie Charges - An untitled volume of documents relating to the charges preferred by Gillespie and Blagrave against Raffles. The documents were printed at Batavia in 1815 for private circulation by Raffles.

Deventer, S. van, L.S. - Bijdragen tot de kennis van het Landelijk Stelsel op Java, (Zalt-Bommel, 1865-6), 3 vols.

Lady Raffles, Memoir - Memoir of the Life and Public Services of Sir Thomas Stamford Raffles, F. R. S. \&6c., (London, 1830).

Deventer, M. L. van, N.G. - Het Nederlandsch Gezag over Java en Onderhoorigheden sedert 1811, ('s-Gravenhage, 1891), Vol. 1. (Volume II was never published).

De Haan, F., "Personalia" - "Personalia der periode van het Engelsch bestuur over Java 1811-1816", Bijd. T.L.V., (1935), Vol. 92, pp. 477-681.

De Haan, F., Priangan, "Personalia", is to be distinguished from the above.

Daendels, H. W., Staat - Staat der Nederlandsche Oostindische Bezittingen, onder het Bestuur van ... Herman Willem Daendels, ... in de jaren 18081811, ('s-Gravenhage, 1814), 1 vol. + 3 Bijlagen.

Sub. - Substance of a Minute recorded by the Honourable Thomas Stamford Raffles... on the 11th February 1814; on the Introduction of an Improved System of Internal Management and the Establishment of a Land Rental on the Island of Java...., (London, 1814).

\section{(b) MANUSCRIPTS :}

Add. Mss. - Additional Manuscripts in the British Museum, London.

Java - Java Factory Records in the India Office Library, London.

Mack. Coll., (Class) - Mackenzie Collection (Class) in the India Office Library.

Mack. Coll., (Misc.) - Mackenzie Collection (Miscellaneous) in the India Office Library.

Mack. Coll., (Pr.) - Mackenzie Collection (Private) in the India Office Library. 


\section{LAND REVENUE IN BRITISH INDIA AND JAVA}

Raffles' ideas on the land rent system in Java can be understood only against the background of the revenue administration in British India during the closing decades of the eighteenth and the early years of the nineteenth centuries. Yet in saying that, we admit a much more complex subject into the discussion than that of the land rent system itself. The scope of these introductory remarks about British India, therefore, must be limited to the broad differences between the Zamindari and Ryotwari systems of revenue collection, particularly in relation to the conflict which developed during Lord Minto's Governor-Generalship concerning the relative merits of the systems. It is important that we understand Minto's views on the subject of land revenue, because Minto had a considerable influence upon the development of Raffles' ideas on the land rent system in Java.

\section{Land Revenue in Bengal.}

The grant of the Diwani to the East India Company by the Mughal Emperor in 1765 gave the Company the right to collect the revenues of Bengal, Bihar and Orissa. ${ }^{1}$ In return the Emperor received twenty six lacs of Rupees per annum. ${ }^{2}$ It was, of course, impossible for the Company to collect its revenue directly from the $R$ yots (cultivators), and so in the early years the revenue administration was left in Mughal hands. ${ }^{3}$ In 1769 the Company made a

1 Muir, R., The Making of British India 1756-1858, (1923), pp. 84-5; Firminger, W. K., The Fifth Report from the Select Committee of the House of Commons on the Affairs of the East India Company, (1917), I, Intro. cliii. (Hereafter cited as Fifth Report, or Firminger for his introductory remarks.) Diwani means the property of the officer in charge of the Revenue Department.

2 Firminger, W. K., I, cliii; Baden-Powell, B. H., The Land-Systems of British India, (1892), I, 391.

3 Harington, J. H., An Elementary Analysis of the Laws and Regulations onacted by the Governor General in Council, at Fort William in Bengal, (1814-15), II, 3. 
valiant effort to prepare a rent roll and to enquire into land titles, ${ }^{4}$ but two years later, when the Directors decided that the Company would stand forth as its own Diwan, ${ }^{5}$ the enquiries made by the Supervisors had produced few trustworthy results. In 1772 a Committee of Circuit was therefore instructed to farm out the lands to the highest bidders for a period of five years. ${ }^{b}$ The results of this farming system were far from encouraging, ${ }^{7}$ and the Bengal Council soon came to realize that a different method of assessment and collection would have to be devised.

During the 1770's Philip Francis began advocating a fixed settlement with the Zamindars. ${ }^{8}$ In a Minute of December 1776 he contended that "the lands are not the property of the East India Company, but of the zemindars and other classes of natives, who owe nothing to Government, but a fixed portion of the new produce". ${ }^{9}$ Hasting opposed the rigidity of this proposal. Although he recognized the importance of forming settlements with the Zamindars, ${ }^{10}$ he strongly supported the claims of the Ryots. "[W] hile the ryot pays his rent", he asserted, "11 "the zamindar has no right to dispossess him; nor can the zamindar, by any legal right, exact a higher rent from him than his pottah prescribes". Francis, however, published the Council debates in England, ${ }^{12}$ and soon began to win adherents to his view that the Zamindars, whom he described as the landed gentry of Bengal, were being annihilated by the policy of the Bengal Government under Hastings. ${ }^{13}$ The Directors themselves were not won immediately by Francis' arguments. They demanded more information before leases were granted in perpetuity. ${ }^{14}$

Annual settlements were made with the $Z$ amindars during the years $1777-80,{ }^{15}$ but arrears in rents continued. ${ }^{16}$ In 1881 an attempt

4 Ibid., pp. 3-6.

5 Ibid., 11; Firminger, W. K., I, ccv; Baden-Powell, B. H., op. cit., I, 393.

(6) Harington, J. H., op. cit., II, 12; Firminger, W. K., I, ccxiii.

Harington, J. H., op. cit., II, pp. 13 et seq.

\& Firminger, W. K., I, ccci.

9 Cited loc. cit.

10 Ibid., I, cccii.

11 Cited loc. cit. A "pottah", or more properly pattā, was a lease.

12 Ibid., I, pp. cccii-iii.

13 Ibid., I, ccciii.

14 Ascoli, F. D., Early Revenue History of Bengal and the Fifth Report, 1812, (1917), 35.

15 Fifth Report, I, 10; Baden-Powell, B. H., op. cit., I, 397.

11 Fifth Report, I, 10. 
was made to reform the collection of revenue by the re-appointment of British Collectors, and the granting of leases for periods up to three years. ${ }^{17}$ In 1884 the proprietary rights of the Zamindars received official recognition, when Pitt's India Act (24 Geo III, c. xxv) ${ }^{18}$ authorized the establishment of permanent rules for the payment of tributes, rents and services from the Zamindars and other Indian landholders. ${ }^{19}$ Two years later instructions were issued to Cornwallis to proceed to Calcutta as Governor-General, and to commence the introduction of a decennial settlement, ultimately to be made perpetual, with the Zamindars. ${ }^{20}$

Much opposition was aroused both in England and India to the recognition of proprietary rights among the Zamindars. James Grant published his Political Survey of the Northern Circars at the end of $1784,{ }^{21}$ in which he argued that the Zamindar was only an official of the state, and that the proprietary rights to the soil were vested in the Sovereign. This view came under attack in 1788 when Shore brilliantly, though somewhat erroneously, contended that the land belonged to the Zamindars, and the rents to the Sovereign. ${ }^{22}$ Some modern scholars, citing the laws of Manu, have found more justice in Grant's views than those of Shore. ${ }^{23}$ Others claim that the laws of Manu recognized private property, and allowed the Sovereign only a proportion of the crop. ${ }^{24}$ The word Zamindar itself means "landholder", being derived from the Persian "Zamin" meaning "land", and "dar" meaning "a holder". ${ }^{25}$ Under the Mughal administration in Bengal, the Zamindars had been drawn from all classes of society, and granted lands in lieu of salaries. Their offices were, therefore, offical ones, although there was a tendency under Mughal rule for them to become hereditary. ${ }^{26}$ This tendency was strengthened during the decline of the Mughal Government. Proprietary rights to the ground, however, were apparently never granted to them. The term

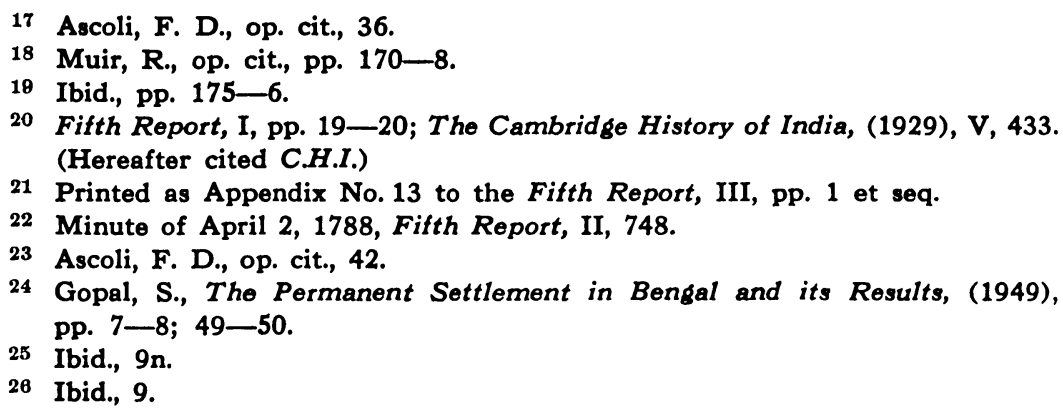


Zamindar, of course, covers so many descriptions of landholders that any discussion of this vexed question of proprietary rights in general terms becomes rather absurd. ${ }^{27}$ Even so, the general insecurity of their tenures was illustrated in 1865 when the Calcutta High Court handed down a judgement which denied the absolute right of the Zamindars to their lands. ${ }^{28}$ And this was seventy two years after those rights had been offically recognized and declared permanent by the Government!

Cornwallis made the permanent settlement with the Zamindars in $1793,{ }^{29}$ three years after they had been issued with decennial leases. ${ }^{30}$ Cornwallis was not so much a supporter of the Zamindars' claims to proprietary rights as has often been asserted, although he did think their claims were better than others. ${ }^{31}$ Nor was he blind to their oppressions. ${ }^{32}$ But he was enamoured of the concept of permanence, which he thought would bring blessings to everyone, not only to the Zamindars. "The security of property", he informed the Directors in August $1799,{ }^{33}$ " . . and the certainty which each individual will now feel of being allowed to enjoy the fruits of his own labours, must operate uniformly as incitements to exertion and industry". He subscribed to the view of the Directors that it was "an object of perpetual settlement that it should secure to the great body of the ryots the same equity and certainty as to the amount of their rents, and the same undisturbed enjoyment of the fruits of their industry which we mean to give to the zemindars themselves". ${ }^{34}$ Shore stated in 1796 that the boon conferred upon the Zamindars by the perpetual settlement had not been at the expense of the Ryots. The rights of the Ryots had been fully

See Ramsbotham, R. B., Studies in the Land Revenue History of Bengal 1769-1787, (1926), pp. 3-4. The most frequently cited definition of a Zamindar under the Mughal constitution, was that given by Harington, and cited by Seton-Karr, W. S., The Marquess Cornwallis, (1890), pp. 34-5. The first two lines of Harington's definition will suffice here. "The Zamindár appears to be a Landholder of a peculiar description, not definable by any single term in our language."

Ascoli, F. D., op. cit., 43; Gopal, S., op. cit., 43.

Fifth Report, I, pp. 35-6; C.H.I., V, pp. 450-1.

30

V, 449; Baden-Powell, B. H., op. cit., I, pp. 399-400.

33 Cornwallis to the Directors, August 2, 1789, Keith, A. B., Spoeches \& Documents on Indian Policy 1750-1921, (1922), 158.

34 Letter to Bengal, September 19, 1792, cited Gopal, S., op. cit., 38. 
protected and secured under the settlement. ${ }^{35}$

How far the permanent settlement in Bengal achieved these aims need not be discussed here. ${ }^{30}$ What at least can be said in its favour was that it produced surplus revenues for the Bengal Government, at a time when the other Presidencies were confronted with large deficits. ${ }^{37}$ The success of the permanent settlement in this respect convinced the Directors that its blessings should be extended. In August 1798, Wellesley gave instructions to the Madras Government to examine the reasons for its financial distress, and expressed the wish that any reform in the southern Presidency should be connected with the introduction of a system of revenue collection similar to that in Bengal. ${ }^{38}$ In the following year direct orders were issued to the Madras Council to introduce permanent Zamindari settlements into the territories under its control. ${ }^{39}$

\section{Munro and the Ryotwari System.}

As a result of the Mysore wars, extensive territories had come under the jurisdiction of the Madras Government. In 1792 Bárámahal and parts of Madura were ceded to the Company. The cession of Coimbatore and Kánara followed in 1799, and that of Malabar in $1801 .^{40}$ In 1800 the districts originally transferred from Mysore to the Nizam were ceded to the Company, and became known as the Ceded Districts.

When the Bárámahal was acquired in 1792, Cornwallis wished to extend the Bengal system there, and he appointed military officers under Captain Alexander Read to undertake the task. ${ }^{41}$ Among Read's assistants was Lieutenant Thomas Munro, who was to become the leading exponent of the principles of the revenue

Minute by Shore, February 1796, cited in Chairs to Mr. Canning, August 2, 1817, Correspondence between Court of Directors \& Board of Commissioners for India, Vol. 3. (India Office Library.) Gopal, S., op. cit., gives a good short account of the weaknesses of the system.

37 Ibid., 26.

38 Bengal to Madras, August 6, 1798, Fifth Report, I, 207.

39 Baden-Powell, B. H., op. cit., III, 17.

40 A complete list of the cessions is to be found in Fifth Report, I, pp. $221-2$.

41 C.H.I., V, 467; Fifth Report, I, pp. 233 et seq.; Baden-Powell, B. H., op. cit., III, pp. 34 et seq.; Ruthnaswamy, M., Some Influences that made the British Administrative System in India, (1939), pp. 284 et seq.; Bradshaw, J., Sir Thomas Munro and the British Settlement of the Madras Presidency, (1894), pp. 61 et seq. 
system which was established in the Bárámahal. ${ }^{42}$ That system, which became known by the term Ryotwari, developed only gradually. In the absence of Zamindars, at least in the Bengal sense, ${ }^{43}$ Read granted annual leases to the village headmen. ${ }^{44}$ But he soon became convinced that the granting of such leases for specified lands at fixed rents was wrong. ${ }^{45}$ As his surveys progressed, he saw the possibility of assessing each field separately, and allowing the $R$ yot full freedom of cultivating his field or surrendering it. ${ }^{46}$ Leases were granted individually to the $R$ yots with simple titles. ${ }^{47}$ Assessments depended upon exact and detailed surveys of the land. ${ }^{48}$ These principles were incorporated in Read's proclamation of $1798 .^{4 \theta}$

Munro remained in the Bárámahal until 1799, but after the fall of Seringapatam in that year, he was appointed to take charge of Kánara. ${ }^{50}$ There he was confirmed in his opinion that the Ryotwari system was the indigenous system of Southern India. ${ }^{51}$ In October of the following year, he was entrusted with the administration of the Ceded Districts, where he remained until 1807. It was not his intention at first to commence a Ryotwari settlement in those Districts. He thought that a just calculation of the existing assessment would suffice. ${ }^{52}$ Leases were therefore granted to the village headmen. ${ }^{53}$ But after 1802 he commenced surveys as a means of arriving at detailed and exact assessments. Munro's defence of the Ryotwar, or Kulwár, system is worth citing in full, because it explains many of the principles upon which it was based. ${ }^{54}$

When a district has been surveyed and the rent of every field permanently fixed, the kulwár Settlement becomes extremely

On Munro, Gleig, G. R., The Life of ... Sir Thomas Munro, (1830), 3 vols; Arbuthnot, Sir A., Major-General Sir Thomas Munro: Selections from his Minutes, \&cc., (1881), 2 vols. I have not had access to the latter work.

54 Cited Baden-Powell, B. H., op. cit., III, 43. 
simple; for all that is required is to ascertain what fields are occupied by each raiyat, and to enter them with the fixed rents attached to them, in his patta; their aggregate constitutes his rent (revenue) for the year. He cannot be called on for more, but he may obtain an abatement in case of poverty or extraordinary losses. He has the advantage of knowing in the beginning of the season... the fixed rents of the different fields which he cultivates....

The kulwár Settlement, though it may appear tedious when compared to the village one, is, however, not only better calculated to realize the revenue, but is, on the whole, a saving of time, because when it is once made there is no further trouble: but in the village Settlement there is so much room for malversation, for many disputes between pátels [headmen] and the raiyats about extra collections on the one hand and the withholding of rents on the other, that more time is consumed in inquiring into these matters than in the original Settlement.

Munro went on to observe that an essential feature of the Ryotwari system was the employment of native officers in the revenue administration. ${ }^{56}$ This feature, together with the difficulties occasioned by the detailed surveys, became the pegs upon which later criticism of the system was hung.

While Munro was engaged in his surveys of the Ceded Districts, the orders of Wellesley and the Directors for the introduction of a Zamindari system into the Madras provinces were being implemented. It was introduced into the Northern Circars and the Jagir with facility, ${ }^{56}$ and into the Bárámahal, although not with as much success. ${ }^{57}$ In October 1807, Munro left India for England. He hoped, among other things, that he might publicize the injustice of extending the Bengal revenue system to Southern India. Three months previously, Minto had succeeded Wellesley as Governor-General.

\section{Minto's support of Permanent Zamindari Settlements.}

Minto had hardly time to acquaint himself with the principles of the Bengal revenue system before he had to deal with a recalcitrant revenue Committee which had been ordered to carry into effect the regulations for a permanent Zamindari settlement in the

See Ruthnaswamy, M., op. cit., pp. 313-5. 
Conquered and Ceded Provinces. In their report of April 13, $1808,{ }^{58}$ the Commissioners, R. W. Cox and H. St. G. Tucker, opposed the settlement in perpetuity upon various grounds, but mainly because they thought the proprietary rights to the ground were not clear, were, in fact, contested. The members of the Bengal Council strenuously resisted this opposition to their instructions. Colebrooke argued with intense feeling for a permanent $Z$ amindari settlement. ${ }^{5 \theta}$

It is of the utmost importance, it is essential for the safety of the state, to conciliate the great body of landed proprietors; to attach to the British Government that class of persons whose influence is most permanent and most extensive; to render it their palpable interest to uphold the permanence of the British domination; to give them a valuable stake in the present administration of the country. This can be in no other way accomplished, but by creating for the proprietors or possessors of the soil a beneficial interest, which emanating from the British Government, would increase with its duration. The landholders enjoying their estates under a moderate assessment fixed in perpetuity, are not ignorant that a change of government would be followed by the exaction of an enhanced assessment.

... I allude to the Zemindars, who are unquestionably the persons possessing most natural influence and effective power over the minds of the people; it is only by conferring on them the benefit of a permanent assessment of the land revenue, [that] that great body, consisting not of a few individuals, but of the numerous landholders of the country, may be suddenly and effectually gained.

Colebrooke was supported in his stand by the other Councillors, ${ }^{80}$ and also by Minto, although he did not minute on the subject. ${ }^{61}$ During September 1808, all the documents relating to the difference of opinion between the Commissioners and the Council were forwarded to the Court for consideration. A covering despatch expressed the uncompromising opinion of the Councillors that after allowing "to $\mathrm{Mr}$. Cox and Mr. Tucker all possible credit, for the motives by

Selection of Papers from the Records at East-India House, relating to the Revenue, Police, and Civil and Criminal Justice, under the Company's Governments in India, (1820), I, pp. 6-44. (Hereafter cited as Selection of Papers.)

59 Minute by Colebrooke, no date, but 1808, Ibid., pp. 50-1.

60 Minute by Lumsden, June 11, 1808, Ibid., pp. 55-61.

61 Extract Revenue Letter from Bengal, September 15, 1808, Ibid., 69. 
which they were influenced ... their report has not occasioned any alteration in the sentiments which we before entertained, with respect to the immediate establishment of a permanent settlement in the Ceded and Conquered Provinces". ${ }^{22}$ Unfortunately the despatch with its enclosures were lost, and it was not until November 1811 that the Directors had an opportunity of considering the Commissioners' report. ${ }^{63}$

Munro and the victory of the Ryotwari System.

In the meantime, Munro was meeting with some success in London in winning support for the Ryotwari system. He had become friendly with James Cumming, who was head of the Revenue and Judicial Department of the Board of Commissioners, and so secured opportunities to express his views in influential circles. ${ }^{64}$ Munro made a favourable impression upon the Select Committee of the House of Commons, which had been appointed in 1808 to consider East Indian affairs, and support began to develop for his views in the Direction. On February 27, 1810, the Directors gave specific orders to the Bengal Government not to establish a permanent settlement of the revenue in the Ceded and Conquered Provinces, ${ }^{65}$ and in November of the following year, they expressed their opinion that an immediate perpetual settlement there "would be premature, supposing the arrangement otherwise to be completely unexceptionable; that it would be attended ultimately with a large sacrifice of revenue; that they were by no means sufficiently acquainted, either with the resources of the country, or with the rights and ancient customs of the different classes of landholders to venture upon a step of so much importance". ${ }^{86}$ The reference to the loss of revenue was to the fear that the Company would lose by any permanent settlement if money values continued to fall.

During July 1812, the Select Committee of the House of Commons issued its Fifth Report, and this publicly called into question the wisdom and justice of the whole principle of permanence in revenue settlements. The publication of the Report, which had been

62 Loc. cit.

63 Harington, J. H., op. cit., II, 336.

64 Philips, C. H., The East India Company 1784-1834, (1940), 202.

65 Despatches to Bengal, LIII, despatch of February 27, 1810, cited Ibid., 202.

86 Cited Harington, J. H., op. cit., II, 337. 
drafted by Munro's friend Cumming, marked the victory of the $R$ yotwari system over its Bengal counterpart. ${ }^{67}$

It appears to the Committee, from the examinations which they have made into the effects of the ryot-war principle of settlement, throughout the modern possessions of the Company under the Madras presidency, that it has greatly improved the situation of the cultivator, by limiting the bounds of the public assessment, and adjusting the actual demand on each person subject to such assessments, according to his ability to satisfy it; by relieving him from the oppressive exactions of the native revenue officers, and securing him in the protection of his property and rights. So favourable a change in their condition, has necessarily excited a confidence among the ryots, in the equity and justice of the Company's government; ... while the natural consequences have been, that the ryots have received a new incentive to industry, cultivation has been gradually extended, by which an augmentation of the public revenue has been yielded, without an increase of assessment.

On December 16, the Directors reversed their orders for the introduction of Zamindari settlements into the Madras provinces, and stated that wherever that system had not been introduced, "the principle of the raiyatwárí system ... shall be acted upon". ${ }^{88}$ Three months earlier they had informed Minto ${ }^{68}$

We cannot admit the policy of realizing the Government revenues by the means of farmers, who... have no other interest in the soil than is derived from their contract. Our own opinion is, that the farming system is oppressive to the contributors, and must be ultimately injurious to the resources of the country; and we therefore give a decided preference to a detailed collection of the revenue [from] the cultivators of the land, by the native cutcherry servants, acting under the immediate authority and superintendence of the European collectors. This mode of administration is, no doubt, troublesome from its details in the early period of its operation; but the labour is considerably diminished, when the rents are once adjusted and the rights of all parties are defined.

To carry the indignity further, the Directors forwarded a number

67 Fifth Report, I, 236.

38 Cited Baden-Powell, B. H., op. cit., III, 32.

n9 Extract Revenue Letter to Bengal, September 9, 1812, Selection of Papers, I, 68. 
of documents relating to Munro's settlement of the Ceded Districts. ${ }^{70}$ "We are particularly desirous of impressing upon your minds", the Court stated, ${ }^{71}$ "the importance of making yourselves thoroughly acquainted with the nature and principles of ryotwar settlement, and with the right and proper course to be pursued in the first introduction of it into a district, before you proceed to the adoption of measures for that purpose, persuaded as we are, that the success of your endeavours, and the extent of the advantages to be derived from the gradual extension of the system, as far as local considerations will admit, to the Ceded and Conquered Provinces, will greatly depend on the manner in which you set about this important, and to your revenue servants on the establishment, perfectly new undertaking".

The Bengal Council reacted sharply to the suggestion of extending the Ryotwari system to the Ceded Provinces. ${ }^{72}$ Minto himself thought that permanent Zamindari settlements were desirable. He believed, as Cornwallis had done, that the granting of permanent and defined rights to the Zamindars resulted in a degree of permanence to the Ryots themselves. But Minto's support of the system was not based upon any idealistic notions concerning the Zamindars themselves. He realized that they were far from being the benevolent task-masters which some supporters of the Bengal revenue system had represented them to be. ${ }^{73}$ Minto was no doctrinaire in his attitude towards the Zamindars, and this, as we shall see, had an important consequence when he came to deal with the Regents in Java.

\section{The Bengal Revenue System and Dirk van Hogendorp.}

The success of the English E.I.C. in drawing large land revenues from Bengal did not pass unobserved by Dutchmen. At the same time as Cornwallis arrived at Calcutta, Dirk van Hogendorp entered upon his duties as Second Resident of the Dutch factory at Patna.$^{74}$ Van Hogendorp soon became an ardent admirer of the British principles of administration, especially of the Bengal

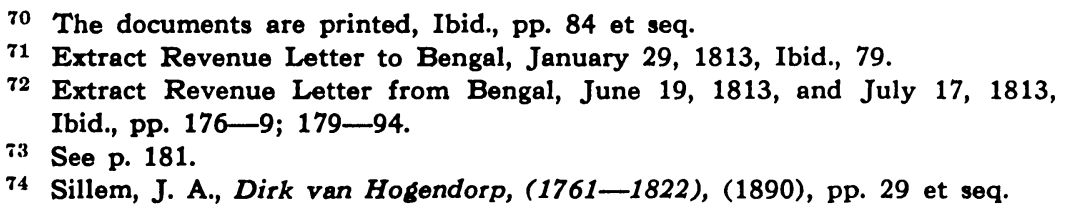


revenue system. ${ }^{75}$ He met Cornwallis himself and was favourably impressed. He wrote to his brother on October 18, 1786: ${ }^{76}$

Last week, together with Titzingh and van Haugwitz, I paid the first official visit to Lord Cornwallis. His Lordship received us with exceptional politeness and friendliness. We spent all day with him, and dined with him together with the members of the Council at Calcutta. He is making many changes and consolidations, which the English do not altogether like. Through his high birth and position in England, he cares nothing for patronage and protection, and because of his wealth and great income, he is not to be bought for money. He thus seems to be the right man to repair the decadent affairs of the English Company ....

In short, he appears to have much knowledge of affairs and a firm intention to look for all abuses, and root them out by the stem. We have been here at Calcutta ten days, and during that time I have had the opportunity of making the acquaintance of many people of great intelligence. Among others with Colonel Ross, General Adjutant, and first secretary of Lord Cornwallis.

When Van Hogendorp left Patna for Java at the end of 1788, he carried with him ideas which were to reach their maturity ten years later, when he published the Berigt. ${ }^{77}$

There is to be found in most of Van Hogendorp's writings high praise for the English administration in Bengal. He contrasted the wisdom of the English in drawing territorial revenues from their possessions to that of the Dutch, who pursued a narrow and exclusive policy of trade.

The English have, by a better administration, by the granting of property of land to its inhabitants, and by separating the administration and the revenues of those possessions from the commercial interests, and bringing them under a separate direction, made their territorial possessions of very much greater importance and profit, whereas we, by adhering to the old system and making the commercial interests the

75 Platteel, P. J., De Grondslagen der Constitutie van Nederlandsch-Indië, (1936), pp. 29 et seq.

76 Du Perron, E. - De Roos, "Correspondentie van Dirk van Hogendorp met zijn Broeder Gijsbert Karel”, Bijd. T.L.V., (1943), Vol. 102, p. 150.

77 Berigt van den tegenwoordigen toestand der Bataafsche Bezittingen in OostIndiën ...., (1799). It was republished in 1800. All following references are to the 1799 edition. 
main object, have neglected entirely our territorial possessions. ${ }^{78}$

Van Hogendorp's main proposal for a reform of the colonial system in Java was the introduction of a territorial revenue, of which the main part was to consist of a land tax. ${ }^{79} \mathrm{He}$ wanted the Javanese "feudal system" 80 abolished, the lands surveyed and classified according to fertility, ${ }^{81}$ and then parcelled out to the Javanese in full property. ${ }^{82}$ The Javanese were to be granted freedom of cultivation, ${ }^{83}$ but in return were to pay a yearly tax on their lands. ${ }^{84}$ Van Hogendorp thought that this land tax would at first be paid in kind, but that ultimately it would be possible to collect it in cash. ${ }^{85}$ He estimated that it would produce a yearly revenue of at least two and a half millions of Rix drs. ${ }^{86}$ In order to prove the feasibility of his plan, he cited the experience of the English in Bengal. ${ }^{87}$ But his proposals for surveys and individual allotment of lands were more akin to the principles of Munro's Ryotwari system than to those of Cornwallis.

There is a striking similarity between Van Hogendorp's ideas and those of Raffles, and later we shall attempt to trace the exact influence which he had upon Raffles. ${ }^{88}$ For the moment, it should be noted that Van Hogendorp's proposals did not appeal to the Commision which was appointed in 1802 to consider the question of colonial reform in Java. Under the astute management of $\mathbf{S}$. C. Nederburgh who was Van Hogendorp's main opponent, ${ }^{89}$ the Com-

See pp. 150-4. Ottow, S. J., De Oorsprong der Conservatieve Richting, (1937), 55, dismisses both Raffles and Van Hogendorp as "publicists" and "wordpedlars".

89 There also existed an intense personal antagonism between the two men. See my "The Rivalry between Dirk van Hogendorp and S. C. Nederburgh", 
missioners issued a report which stated that the time was not ripe for any dangerous experiments with Javanese society. ${ }^{90}$ They denied the relevance of the British experience in Bengal to the situation in Java. ${ }^{91}$ However, Van Hogendorp's ideas were behind Daendels' experiment of a regulated land system in Tjirebon, ${ }^{82}$ and they can be found to varying degrees in the reports which were submitted to Raffles by various Dutchmen, especially by Muntinghe, ${ }^{83}$ during the early years of the British administration of Java.

Indonesië, (July, 1953), Vol. 7, No. 1, pp. 80-5 for a sidelight upon this subject.

mo De Commissie tot de Oost-Indische Zaken, aan Het Staatsbewind der Bataafsche Republiek, August 31, 1803, Mijer, P., Verzameling van Instructiën, Ordonnanciën en Regelementen voor de Regering van NederlandschIndië...., (1848), pp. 129-30.

91 Ibid., 133 et seq. For various accounts of Van Hogendorp and the 1803 Commission, Klerck, E. S. de, History of the Netherlands East Indies, (1938), II, 10; Day, C., The Policy and Administration of the Dutch in Java, (1904), pp. 134 et seq.; Graaf, H. J. de, Geschiedenis van Indonesië, (1949), pp. 358-61; Welderen Rengers, D. W. van, The Failure of a Liberal Colonial Policy Netherlands East Indies, 1816-1830, (1947), pp. 14-6; Furnivall, J. S., op. cit., pp. 56-64; Encyclopaedie van Nederlandsch-Indië, (18951905), II, p. 46-7. Vlekke, B. H. M., Nusantara, (1945), pp. 222 et seq.

92 Deventer, S. van, L.S., I, pp. 38-44; Daendels, H. W., Staat der Nederlandsche Oostindische Bezittingen, onder het Bestuur van... Herman Willem Daendels...., (1814), Bijlagen II, Organique Stukken, Cheribon, No. 2. (Hereafter cited as Staat.)

93 Veth, P. J., Java, Geographisch, Ethnologisch, Historisch, (1896-1907), II, 333, stated that the reform of the Java administration, in which Muntinghe had played a not inconsiderable part, often rested upon ideas which Van Hogendorp had previously developed. But see pp. 152-3 below for a discussion of Muntinghe's attitude to Van Hogendorp. 


\section{THE BEGINNINGS \\ OF THE LAND RENT SYSTEM IN JAVA}

\section{Minto's Instructions on Land Reform.}

Raffles was appointed Lieutenant-Governor of Java by Minto's commission of September 11, 1811. ${ }^{1}$ In a proclamation of the same date announcing the appointment, his Lordship outlined the general principles which were to guide the new administration. On the question of the Dutch economic system, he stated: ${ }^{2}$

The vexatious system of monopoly which is understood to have hithertofore prevailed in some instances to an oppressive and inconvenient extent, will be revised, and a more beneficial and politic principle of administration will be taken into consideration as soon, and to such extent, as full information on the subject can be obtained, as established usage and habit may admit, and as may be consistent with a due regard to the health and morals of the people.

During the remaining five weeks which he spent on the island, Minto diligently collected as much information on the state of Java as was possible, especially relating to the question of land tenures. "I applied myself with as much assiduity", he wrote later, "in a very short interval admitted, to obtain a knowledge of the tenures $\&$ conditions under which landed property was held through all the gradations from the Landlord down to the husbandman \& actual cultivator, of the soil of the coffee $\&$ other lands cultivated by public officers \& servants on behalf of the Government itself, of the system of exactions of grain $\&$ other produce in kind at arbitrary $\&$ inadequate prices, commonly known by the name of contingents." Minto's

1 Boulger, D. C., The Life of Sir Stamford Raffles, (1899), 136.

2 Lady Raffles, Memoir, 103. The draft of the proclamation is in Raffles Collection, III, No. 21.

3 Minute by Minto, August 3, 1813, Bengal Civil Colonial Consultations, August 16, 1813. 
information was based upon first hand reports from the Residencies, but he probably gathered more helpful information from the Dutchmen Muntinghe and Cranssen, who had been appointed to the Java Council. ${ }^{4}$

On the day prior to his departure for Bengal, Minto presented Raffles with the following instructions for a reform in the revenue administration of Java. ${ }^{5}$

The late System was that of farming the revenues of every description. The Chinese were the farmers \& from the circumstances of the country at large, had got exclusive possession of the farms.

The vicious nature of this System is obvious, and has been felt both by the Government $\&$ the subject.

A sudden and general transition from this plan, to collection by the officers of Government is not practicable; but the utmost efforts should be made to establish the latter system with the least practicable delay.

It has already been put in activity in the port of Batavia, and may probably be extended to the Export and Import duties at the principal ports on the North Coast, and at Sourabaya, at an early period.

I should hope that the new mode of collection may become in a great degree general by the beginning of the ensuing half year. ...

The revenue of coffee is obtained by a profit on the exclusive culture and sale of that commodity.

The whole system appears to me vicious.

First the actual culture of the land on account of Government.

Secondly, the monopoly of the sale and exportation.

To remedy the first inconvenience must probably be a slow process, and will require much enquiry and reflexion, as well as a cautious and gradual execution.

Government should throw the coffec lands into the hands of private industry. This cannot yet be accomplished by sales in perpetuity subject to quit rents for the indemnification of Government. There is not private capital enough at present for

4 Minto stated that his "considerable body of information" was procured from both "written \&o oral" sources, loc. cit.

5 The instructions are dated October 18, 1811, and form Enclosure 3 of Minute by Minto, Ibid. Part of the instructions were printed by Raffles in Gillespie Charges, Appendix RR, pp. 269-70. They also appear in Anon., Official and Secret Papers Relating to the Sale of Lands and Other Subjocto During the British Administration of Java, (1883), pp. 1-2. Italics mine. 
such an operation; but it may be invited from without, and I hope will accumulate within, at no distant period.

Leases for moderate periods appear to me the best way of commencing this process, but even this should in the present state of society and of industry be attempted only gradually. Let one or two lots of thase lands be let for any number of years thought advisable, say ten, on the terms and conditions to be hereafter approved of. And as a step also towards a departure from the monopoly, let the coffee of those farms be saleable by, and for the benefit of, the farmer, and exported on a proper duty.

Contingents ${ }^{6}$ of rice, and indeed of other produce, have been hitherto required of the cultivator by Government at an arbitrary price.

This also is a vicious system to be abandoned as soon as possible.

An abolition of the contingent, a perfect freedom in the cultivation and sale of rice, will soon render it unnecessary for Government to provide immense stores of grain for the food of the people whom a free market will supply without the intervention or providence of authority. This system of contingents did not originate in a mere solicitude for the supply of the people, but was a measure at once of finance and control to enable Government to derive revenue from a high price imposed on the consumer, and to keep the whole body of the people dependent on its pleasure for subsistence.

I recommend a radical reform in this branch to the serious and early attention of Government.

The principle of encouraging industry in the cultivation and improvement of land by creating an interest in the effects and fruits of that industry, can be effected in Java only by a fundamental change in the whole system of landed property and tenure.

A wide field, but a somewhat distant one, is open to this great and interesting improvement. The discussion of the subject, however, may be safely, and must be necessarily, delayed till the investigation it requires is more complete. I shall transmit such thoughts as I have entertained and such hopes as I have indulged on this grand object of amelioration, but I am to request the aid of all the information and all the lights the Island can afford.

On this branch nothing must be done that is not mature;

6 Most of the last part of the instructions is printed in $H$. of J., I, 153; Lady Raffles, Memoir, 212; and Sub., pp. 4-5.

7 Compare Minto to the Secret Committee, October 5, 1811: "[T]he whole system of property is vicious, and adverse alike to the Interest of Government and People". Bengal Secret Lotters, Vol. 13. 
because the change is too extensive to be suddenly or ignorantly attempted. But fixed and immutable principles of the human character, and of human association, assure me of ultimate, and I hope not remote success in views that are consonant with every motive of action that operate on Men, and are justified by the practice and experience of every flourishing country in the world.

I shall abstain under the present circumstances from all instruction, and from further discussion on a subject reserved for future enquiry and deliberation.

In separate orders, Minto forbade the Residents at Solo and Yogyakarta from deriving any advantage from the farms of birds'-nests, and they were instructed to come to some arrangement with the Courts for vesting the farms in the Company. ${ }^{8}$ They were to superintend the collections of the farms, and were to be granted a small commission on the net proceeds. ${ }^{9}$

Minto's instructions on the revenue system were not precise, nor indeed were they meant to be. They were, he said later, ${ }^{10}$ "intended only as a sketch which his [Raffles'] knowledge of my general views and his own research, discernment $\&$ prudence afforded the assurance of his filling up as perfectly and as quickly as zeal, guided by sound discretion, could enable him to perform so great and delicate a task."

\section{The Appointment of the Mackenzie Land Tenure Commission.}

Immediately after Minto's departure, Raffles commenced the reorganization of the administration. On October 22, he appointed a Committee under the presidency of the two Dutch members of Council to register all the documents and records in the archives in Java, and to this Committee added Lieutenant-Colonel Colin Mackenzie. ${ }^{11}$ The latter was soon to become an important instrument in Raffles' land reforms.

Mackenzie had acted as Chief Engineer of the British expedition to Java, and his detailed reports on the disposition of the DutchFrench military forces before the invasion had contributed substan-

s Order dated October 18, 1811. Enclosure 1 of Minute by Minto, August 3, 1813, op. cit.

Hoc. cit.

10 Minute by Minto, August 3, 1813, op. cit.

11 "Report and Journal... of Lieutt. Colonel Mackenzie....", Mack. Coll., (Pr.), Vol. 14, No. 15b. See also De Haan, F., "Personalia", 600. 
tially to its success. ${ }^{12}$ After the fall of Meester Cornelis, he had sought Minto's permission to remain on the island in order to collect various Dutch records, and investigate the state of the country. When the Governor-General agreed, Raffles eagerly availed himself of Mackenzie's services. Before he had joined the Java expedition, Mackenzie had had many years of survey experience in British India. He had conducted the exacting survey of Mysore, and at the time of the Java invasion was Surveyor-General on the Madras Establishment. He knew both Read and Munro, the supporters of the Ryotwari system, and it has been assumed that it was Mackenzie who gave Raffles the ideas for this particular type of revenue settlement. ${ }^{13}$ We will return to this question later. For the moment let us consider Mackenzie's activities during the early months of the British administration of Java.

In order to obtain information about agricultural and economic conditions in Java, Raffles, on November 18, began circulating to present and past officials certain queries to which he demanded prompt answers. ${ }^{14}$ Permission was given to use the archives in the preparation of the answers, and the officials were to collect the opinions of their subordinates on the various questions. ${ }^{15}$ At the end of the month, Mackenzie left Batavia for a personal investigation of the districts along the North East Coast, and the Residents were instructed to furnish him with all the information he required. ${ }^{16}$ In order to speed the investigation another questionnaire relating to problems of land tenure, was circulated in the middle of December to the various civil authorities on the island. ${ }^{17}$ Before there was time

12 Many of the reports are in Mack. Coll., (Pr.), Vol. 14. See also Mackenzie, W. C., Colonel Colin Mackenzie, First Surveyor-General of India, (1952), pp. 101-122. I have taken some of my facts about Mackenzie from D.N.B., (1893), Vol. XXXV, pp. 138-9; Blagden, C. O., Catalogue of Manuscripts in European Languages belonging to the Library of the India Office. The Mackenzie Collections, (1916), Vol. I, Part I, Preface and Introduction, pp. vii-xoxii.

13 Dodwell, H. H., "The Straits Settlements, 1815-1863", Cambridge History of the British Empire, (1940), Vol. II, Chapter XVI, 596.

14 De Haan, F., Priangan, (1910-12), II, Appendix L, 680.

15 Loc. cit.

16 Loc. cit.; and De Haan, F., "Personalia", 600.

17 "Heads of a Memoir of the Regentship or District of - in Java intended for obtaining a complete Geographical \& Statistical View of the Island communicated for circulation by Lieutt. Colonel Mackenzie", Mack. Coll., (Pr.), Vol. 14, No. 16 (iv). De Haan, F., Priangan, II, 680, wrongly stated that the questionnaire was circulated in November. 
for any replies to come in, however, Raffles decided to appoint an offical Commission to investigate the whole subject. In January instructions in Dutch were addressed to F. J. Rothenbühler, J. Knops and $P$. $H$. van Lawick van Pabst ${ }^{18}$ to act under Mackenzie's presidency, and to consider how the existing revenue system could be replaced by one of free trade and cultivation. Joint instructions in English were issued to the Commission on January 21, and in these Raffles showed clearly in which direction he expected the enquiry to proceed. ${ }^{10}$

It now becomes necessary that Government should consider the inhabitants, without reference to bare mercantile profits, and to connect the sources of the revenues with the general prosperity of the Colony.

The system of monopoly and obligation to deliver products at stipulated prices, and of contingents, cannot be viewed otherwise than a check to industry and in opposition to the general prosperity of the community, and it must be equally prejudicial and dangerous to subject the chiefs and Regents of the Javanese to an imposition in money by which the population are exposed to any consequent levy of taxes which the Regents may lay upon them.

It is, therefore, the wish of Government that this system should in process of time be abolished, and that a free trade and free cultivation, accompanied by such regular and fixed taxes as may be sufficient to defray the necessary expenses of the Colony, should be substituted in lieu thereof.

But at the same time that Government indulge the hope that such a change may eventually be made, they are satisfied that the same cannot be attempted but by degrees and a progressive system of improvement.

With a view of effecting this general change at as early a period as practicable, and which I hope may in a few years be considerably proceeded on, I have deemed it expedient to appoint you a Committee under the following instructions ....

It is known in general with respect to the object of your inquiry that the native Regents dispose in a very arbitrary manner of the lands and principally of the rice fields in their districts.

18 For details of these three, De Haan, F., "Personalia", pp. 634; $5918593-4$. On Rothenbühler, Ketjen, E., "Levensbericht van F. J. Rothenbühler", Verh. Bat. Gen. van Kunsten en Wetenschappen, (1881), Vol. XLI, pp. 71-3.

19 Java Public Consultations, January 21, 1812. There is another copy in Mack. Coll., (Pr.), Vol. 35, No. 2. The instructions have been published by Wright, H. R. C., "Muntinghe's Advice to Raffles....", op. cit., pp. 222-5. 
That they distribute important shares of them to their relations and other persons in whom they are interested, and that a certain portion thereof is set aside for the use of those inhabitants or villagers who are employed in the forced culture of coffee or in other feudal services. But it is not in such general statements that my present intention will be answered. I flatter myself that in your report I shall find a satisfactory elucidation on the following points.

Whether in fact the common Javanese looks upon his Regent as the early proprietor of the soil, with a right to appropriate to himself all the fruits thereof, or whether on the contrary, he thinks himself qualified and entitled with his fellow inhabitants of his Dessah or village to the possession and use of those lands by paying only a certain share of the fruits to his chiefs? What dispositions of the Regents respecting the lands and their tenure and produce are considered by the common Javanese as perfectly legal and what as contrary to custom? ... Whether the existing possession of, and disposition over, the products of these grounds, do not prove that there subsists a certain right of property upon the grounds in the common Javanese?

Is it practicable to introduce a right of property on the lands and in what manner may the same be effected with the most facility?

Is it not practicable in such an event to satisfy the Regents by giving to them an actual property in a certain part of their districts only, granting the remainder of the lands in property to Javanese or to Europeans or to both indifferently?

Would it be most useful to divide the property in such cases in great, or small, parcels?

In the event of its being judged most eligible to divide the lands into large properties, could not the rice fields be easiest divided among the principal natives who are in rank next to the Regents, and the other inhabitants of those lands be employed on the terms of tenants or farmers, with fixed limitations respecting the term and hire of each farm, the manner of giving notice to quit, and the cases in which forfeiture of rent shall take place, in the same manner as such regulations exist in Europe?

On the contrary, would it not be advisable that the grounds which are already employed for the cultivation of coffee by Government and otherwise, and other parts of the country, should be granted in property to Europeans?

In that case, could not the cultivation of such lands or plantations be carried on by fixing on each property or parcel a certain number of Javanese families or villagers who should have no share in the property, but whose subsistence might be sufficiently ensured by their being granted the produce by the way of farm or paying a rent - or could not their industry 
be sufficiently encouraged by ensuring to them by a Resolution of Government fixed daily wages for their labour to be demanded and given, and prohibiting all punishments and acts of oppression on the side of the landlord?

Could not the voluntary labour of those people be further ensured by their being left under the superintendence of their native headmen, who may in such cases continue and be the person through whom the landlords may direct the services of the labourers?

Is not the possibility of such a direction demonstrated by the manner in which at present certain villages and countries are employed in the cultivation of coffee for Government, in the felling of timber in the forests, in the salt-pans, and birdnest cliffs? Could not the difficulty which exists from those people at present depending entirely or partly for their reward on the possession of a certain number of rice fields, be removed by giving to each parcel of property in land a certain extent of low ground calculated for the culture of rice, sufficient for the subsistence of the cultivators?

By what means the private property of land, if the introduction of the same be thought practicable, might be most easily and advantageously transferred either to Javanese or Europeans?

Whether the same could not be most advantageously transferred to the Javanese on condition of the payment of a yearly ground-rent to Government, calculated on the actual value of the lot?

Or whether the same, on the contrary, could not be most advantageously transferred to Europeans by public sale, after an accurate survey, measurement and valuation of the same lands should be made by Government, as well to foreigners as to the inhabitants of the colony?

What are the first steps which might be taken to serve as a proof how far the introduction of such a system of property of ground and of free cultivation is likely to answer?

And whether these steps could not in the first instance be most safely undertaken in the neighbourhood of the two principal towns of Java - Samarang and Surabaya -, where the European power will always be at hand to check any unexpected consequences that may arise? ....

By what means Government may under such a system of property of ground, free trade and free cultivation be indemnified for the loss of monopoly, forced deliveries of produce, and contingents?... What are at present in each Regency the nature and amount of the taxes which are paid by the Javanese, whether in kind or in money, to their chiefs and Regents, and in the event of its being considered that the Javanese have not yet the faculty to bear a sufficient tax to 
be levied in money, whether in that case they could not be subjected partly to a tax in kind, payable optionally in money?

The questions which Raffles set for the Commission show clearly the influence of Minto's instructions and hint at some sort of Zamindari settlement for the sawahs - a Zamindari settlement, however, in which the Regents were not to play the part of Zamindars. ${ }^{20}$

\section{The Early Meetings of the Mackenzie Commission.}

The members of the Land Commission met for the first time on February 8, 1812, near Surabaya. They decided that the best way for the Commission to proceed in its task was for the members to engage in a personal inspection of Java, "as the opinions of the Landdrosts, Regents $\&$ others interested in the results, cannot be alone sufficiently relied on". ${ }^{21}$ Rothenbühler was appointed to investigate the Eastern Districts from Tuban to the Oosthoek; Knops from Tuban to Pekalongan, and Lawick van Pabst from Pekalongan to the Priangan, including Tjirebon. The results of the individual investigations were then to be considered by the Commission as a whole, and eventually forwarded to the Government. A letter was addressed to Raffles asking permission for the Commission to divide in this manner. ${ }^{22}$

Mackenzie himself was opposed to the breaking-up of the Commission. He would have preferred the members to have visited each district together, as this had been his experience of the Committee of Circuit on the Madras Establishment. But the Dutch members insisted that it would be only by close individual investigations that any useful information would be obtained. Mackenzie acquiesced finally because, as he told Raffles, ${ }^{23}$ he had been impressed by the exertions of individuals, particularly of Read in the Bárámahal and

20 This qualification must be made to Wright, H. R. C., "Muntinghe's Advice to Raffles....", op. cit., 225.

21 "Minutes of the Committee on the State \& Amelioration of Java 1812-13", February 8, 1812, Mack. Coll., (Pr.), Vol. 35, No. 1. Another copy is in Bongal Civil Colonial Consultations, March 19, 1814.

22 Mackenzie to Raffles, February 9, 1812, "Letter Book [of the] Commission", Mack. Coll., (Pr.), Vol. 35, No. 21, Letter No. 1; and Java Public Consultations, February 21, 1812.

23 "Commission for the Affairs of Java - Report of the President", August 11, 1812, Mack. Coll., (Pr.), Vol. 35, No. 20. 
Munro in Kánara and in the Ceded Districts, in analysing the mode of revenue collection in British India. Mackenzie's proposal for periodical meetings of the Commission at some central point for personal communication between the members was also over-ruled by the Dutch members. They thought that such meetings would hinder the actual work of the investigation. ${ }^{24}$

The Commission met for a second time at Surabaya on February 9 , when it was decided that the Dutch members would prepare Heads of Enquiry to facilitate the investigation..$^{25}$ Mackenzie suggested that the queries already circulated by the Government to the civil authorities in November and December should be referred to on such points as were suitable for the investigation, and that Raffles should be requested to forward any replies for the information of the Commission.

When the Commission reassembled a week later to consider the drafts of the Heads of Enquiry, Mackenzie agreed to have them translated into English, and circulated to the Civil Commissioners and other authorities on the island. ${ }^{26}$ De Haan has published an almost complete list of the Queries, but wrongly attributed their authorship to Raffles. ${ }^{27}$ An English version of the original Dutch Queries is in the Mackenzie Collection, (Private), Vol. 35, No. $4 .^{28}$

The Commission adjourned on February 17, pending the arrival of Raffles' permission that the Commission could divide. In the meantime, Mackenzie and Knops travelled to Banjuwangi "for the purpose of obtaining a general view of the country"; ${ }^{28}$ Lawick van Pabst returned to Djapara, and Rothenbühler remained at Surabaya to have the Queries copied for circulation.

Raffles readily granted permission for the Commission to breakup, but insisted that before it did so, the members should first answer the general question contained in their instructions, - whether or not a change in the existing system of trade and cultivation in Java

24 Loc. cit.

25 "Minutes of the Committee....", op. cit., February 9, 1812.

26 Ibid., February 16, 1812.

27 De Haan, F., Priangan, II, 681. The Queries are on pp. 683 et seq.

28 Another English copy is in Bengal Civil Colonial Consultations, March 19, 1814. In some cases the English Queries are fuller than those published by De Haan. Some of the Dutch Queries are in Eindresumé, II, Bijlage NN, pp. 166-75. Queries in Malay were also circulated.

29 "Minutes of the Committee....", op. cit., February 16, 1812. 
was possible. "As the superior ability $\&$ information of the Gentlemen composing the Committee," he wrote, ${ }^{30}$ "afford sufficient grounds to believe that they are already adequately prepared to discuss the principal point of the Investigation, namely to ascertain the possibility or impossibility of adopting a different system of agriculture \& commerce, I have no doubt you will be able to treat this question with every important consideration previous to separation." Raffles was doubtless anxious to show Minto that something concrete was being attempted in the way of land reform, but his letter displays not only an impatience for a programme of reform, but also a rather doctrinaire attitude to the whole investigation. On February 17, he burdened the Commission with the additional task of investigating all applications made by individuals for the purchase of lands in the neighbourhood of Semarang and Surabaya. ${ }^{31}$

When the Commission met at Pasuruan on March 9 to consider Raffles' requests, the Dutch members replied to the first rather abruptly. "[Although] a change might be made in the Commerce \& Agriculture directed by the wisdom of Government," they stated, ${ }^{32}$ "... it is impossible at this moment for [us] to declare in what \& which manner that ought to be fixed." The Commissioners agreed, however, that some investigation of the lands about Surabaya and Semarang would have to be made if sales were contemplated, and Mackenzie prepared a "Memorandum" of questions which they would have to keep in mind during this investigation. ${ }^{33}$ The "Memorandum" showed Mackenzie's awareness of the dangers of disposing of lands, so far as their occupants were concerned. On March 22, the Commission again discussed the subject of the Surabaya lands. ${ }^{34}$ Two days earlier the Dutch members had handed

30 Raffles to Mackenzie and the other members of the Committee, February 17, 1812, Mack. Coll., (Pr.), Vol. 35, No. 3.

31 "Report of the President....", op. cit.

32 "Minutes of the Committee....", op. cit., March 9, 1812. This opinion was conveyed to Raffles in a letter of March 26, "Letter Book [of the] Commission", op. cit., Letter No. 5.

33 "Memorandum by the President for the Members proceeding to Soorabaya", Mack. Coll., (Pr.), Vol.35, No.6. Note question 5: "Will any individuals suffer by the sale of these lands; to what extent, \& what compensation has been usually made in such cases to persons occupying the lands?....". A Report answering these queries is in Ibid., No. 8. See also "Report of the President....", op. cit.

34 "Minutes of the Committee...", op. cit., March 22, 1812; and "Report of the President....", op. cit. 
in a long "Advice" ${ }^{35}$ on this and other questions relating to reform. They pointed out that they could hardly advise if lands at Surabaya and Semarang should be transferred to individuals, because Raffles had stated in their instructions that such questions were not to be decided upon until the conditions of tenure and cultivation had been carefully investigated. It seemed further implied in these instructions that until the general question regarding free trade and cultivation had been answered, no transfer of lands to individuals was to take place. If it was now the intention of the Government to dispose of lands during the current year, then the Commission could hardly advise on a decision which had already been taken. They thought that until they had come to some conclusions about the question of free trade and cultivation "the lands ought to be kept in some degree on the present footing in order to leave the opportunity to the Native Regents to deliver to government the taxes to which they are bound; for tho' it is true . . they could be provisionally released from a part of their taxes, who is the man that can give exactly ... what are the real charges \& revenues of the Native Regents?" 36 There was, they said, "a dark cloud" spread over the whole subject. Moreover, care would have to be taken if sales of land were eventually decided upon, to make certain that purchasers possessed enough capital to invest in their properties, otherwise little would be achieved in the way of improving cultivation. An investigation would be necessary before such a sale to determine

(i) what proportion of the produce on the private estates the people would be required to pay to the proprietors,

(ii) what quantities of land should be set aside for the sustenance of the Regents and chiefs,

(iii) what lands should form the Ommelanden of the towns, and (iv) the fertility and cultivation of the lands proposed to be sold.

This investigation, the Commissioners concluded, would require much time, and divert their attention away from the more fundamental question regarding free cultivation. They suggested that the Commission should continue to receive applications for the purchase of lands, but that they should reserve their judgement about the

\footnotetext{
35 "Advice given in by the Members of the Commission on the 20th March 1812", Mack. Coll., (Pr.), Vol. 35, No. 13.

30

Loc. cit.
} 
applications until they had submitted a comprehensive report on the matter of free trade and cultivation. ${ }^{37}$

In a covering letter of March 26 in which the "Advice" was forwarded, ${ }^{38}$ they referred to Raffles' request that they should commit themselves to a definite statement about a new system of cultivation before they separated for their individual investigations. "We have considered it," they wrote, "[but] are unanimously of the general opinion that altho' a change in the trade \& culture may be most desirable \& necessary, we cannot as yet determine on any manner how it could be immediately effected". They hoped that Raffles would agree to "the expediency of further investigation previous to [a] final decision on so important a subject", and informed him that although they would carry out individual investigations, they would meet as a combined Commission to draw up a comprehensive report on a new system of cultivation. In the meantime, they requested that Javanese writers be attached to the Commission to facilitate their work. They separated finally, after a meeting at Surabaya on April $7 .^{39}$

\section{Raffles realizes that reform must proceed slowly.}

The unwillingness of the members of the Mackenzie Commission to commit themselves to any doctrinaire programme of reform, made Raffles realize that land reform would have to proceed slowly. At this time, he himself had no panacea for Java's ills, and although he showed some impatience in demanding from the Commission suggestions for reform, he was doubtless content to continue the old system of monopoly, forced deliveries and contingents. Raffles had not yet felt the financial pressure caused by a failure of exports, and the consequent depreciation in the paper currency. On March 19,1812 , he had written privately to the Chairman of Directors of the E.I.C. giving a rosy picture of Java, but complained of the difficulty "of applying what may be considered as the more enlightened principles of the British Government". ${ }^{40}$

37 By this time twenty eight applications for land had been received by the Commission. One was from De Wilde for the purchase of part of Bandung. See p. 83.

38 Members of the Commission to Raffles, March 26, 1812, "Letter Book [of the] Commission", op. cit., Letter No. 5.

39 "Minutes of the Committee....", op. cit., April 7, 1812.

40 Raffles to the Chairman of Directors, March 19, 1812, Java, Vol. 67. Parts of this despatch are in Lady Raffles, Memoir, pp. 105-6. 
"The great quantity of Prize Property and particularly of Coffee which still remains on this Island", he wrote, "renders any change in the present System of Coffee culture, as recommended by Lord Minto, impracticable, but I have great hopes that the accomplishment of the grand plan of amelioration in this and other respects respecting the agriculture and cultivation of this Island is not far distant. I have an intelligent Committee of which Colonel Colin Mackenzie... [is] President, now sitting in the Eastern Part of the Island, and from the result of their labours I trust to be possessed of such additional lights as may lead eventually to a complete change of the present system of landed property, without which little can be expected".

The two important points upon which Raffles wanted the Mackenzie Commission's opinions were

(i) the exact rights of the Regents to their lands, and

(ii) whether these rights could be satisfied by granting them small estates, and so permit the remainder to be distributed as private property either to the Javanese and/or to the Europeans.

During the early part of 1812 , although he knew of the theoretical claims of the Company to the sovereignty of the ground in its own districts, Raffles was not certain how far usage had given the Regents a proprietary right to the soil. He expressed his private opinion to Minto that the "Chiefs and Regents ... may be considered in the light of extensive Landlords who deliver to Government the cash and rice ... for the use and right of the Districts entrusted to their charge". 41 And in his letter of March 19 to the Chairman of Directors he had explained that

with the exception of the estates in the neighbourhood of Batavia, and of a few lately sold at Sourabaya, the whole landed property in Java is held on an acknowledged feudal tenure. The Soosoohonan and Sultan are the lords paramount in their districts; and although the Company are literally so in the districts properly termed the Company's provinces, the power is transferred universally to the Regents, who on condition of furnishing a certain quota or contingent of produce, and in some cases of money, and rendering with their people

41 Raffles to Minto, January 29, 1812, Java Public Consultations, February 1, 1812. Italics mine. 
certain feudal service when required, are possessed of absolute authority within their respective districts. ${ }^{42}$

Because of these supposed rights, Raffles thought that caution would be necessary in attempting a plan of reform. "Although a material change may be gradually introduced," he informed the Secret Committee of the E.I.C. on March 25,43 "and an entire change of System eventually contemplated, it will be evident that a sudden alteration in this System would be, if not impossible, at least highly dangerous, and that therefore the revenues of the Island will, at least for some years to come, be closely connected and entirely dependent on its mercantile management under the Honble. East India Company." Therefore, when Raffles presented his first financial estimates to Minto at the end of January 1812, he based them upon the assumption of a continuation of contingents and forced deliveries. ${ }^{44}$ He estimated that the contingents of rice would amount to 20,000 koyans, and coffee to 130,000 pikuls. On the latter produce he calculated a profit of $25 \% .^{45} \mathrm{He}$ also expected high profits from the Government sales of opium, from a monopoly of Amboina spices, which he hoped would be shipped via Batavia, and from customs and mercantile speculations, including a voyage to Japan. ${ }^{46}$ But in order to secure immediate finance for his administration, Raffles suggested to Minto that a partial sale of lands be made for "the encouragement of cultivation". ${ }^{47}$

Minto's instructions on the subject of the coffee lands had become fairly general knowledge by 1812 , and many applications from both European and Chinese had been received by the Government for parcels of land all over the island. These had been forwarded to the Mackenzie Commission for consideration. In the meantime, Raffles had to make up his mind about a sale of lands which had already taken place under Daendels' administration. This was the sale of Besuki, Panarukan and Probolinggo to the Chinese.

42 Raffles to the Chairman of Directors, March 19, 1812, op. cit.

43 Raffles to the Secret Committee, March 25, 1812, Java, Vol. 67.

44 Raffles to Minto, January 29, 1812, op. cit.

45 Loc. cit.

46 On Raffles' commercial ventures to Japan, Paske-Smith, M., Report on Japan to the Secret Committee of the English East India Company, 1812-1816, (1929).

47 Raffles to Minto, January 29, 1812, op. cit. 
In the middle of 1810 , Daendels had disposed of the lands of Besuki and Panarukan to the Captain China of Surabaya, Han Tjan Pit. The lands had previously been rented to him for life. The sum which he agreed to pay for the purchase of the lands was $400,000 \mathrm{Sp}$. drs., a quarter more than the estimate made by the Government Committee appointed to value the lands. Payment was to be made by Han Tjan Pit assuming the Government's debts at Surabaya, and by paying the remainder in instalments. ${ }^{48}$

The success of the sale encouraged Daendels to dispose of Probolinggo which produced only scanty revenues. The brother of Han Tjan Pit, Han Kiko, the Captain China of Pasuruan, offered 600,000 Sp. drs. for the district, but under the final terms agreed to pay one million Rix drs. to the Government in twenty instalments of 50,000 Rix drs. each. To gain an immediate financial benefit from the sale, Daendels issued a paper currency to the value of the total sale, and proposed to withdraw it in proportion to the amounts of half-yearly instalments paid by the Chinese. Discount on the notes was stricly forbidden, but the exceptions made by the Government Treasury in receiving this paper for payment, and its unacceptability in the Principalities, resulted in a sharp depreciation. By the time the British arrived in Java, the paper money had depreciated to $50 \%$ of its original value.

Minto helped restore some degree of confidence in the paper currency when he recognized it as a circulating medium, and fixed its value by proclamation at $61 / 2 \mathrm{Rix}$. drs. paper to $1 \mathrm{Sp}$. dr. silver. But specie was in short supply, and the shipments of prize property and the payment of the military forces in silver, accentuated its scarcity, and caused a further depreciation.

During the early months of his administration, Raffles had to decide whether he would recognize Daendels' sales in the Oosthoek. The recognition of the paper currency by the Government did not necessarily mean recognition of the sale of lands. Raffles therefore sought the advice of various Dutchmen on the question. One of these, P. A. Goldbach, who had lived twenty years in Java, and had much

48 For further details on this subject, see my "The Chinese Estates in East Java during the British Administration", to be published in Indonesië, during 1954, and Wright, H. R. C., "Improvement in the East Indies", The Cambridge Journal, (August, 1953), Vol. VI, No. 11, pp. 688-94. 
experience in the Oosthoek, warned the Civil Commissioner, H. Hope, in December 1811: ${ }^{\mathrm{s0}}$

[I]f there be a place where riot and rebellion may be apprehended, it is at Probolingo, where there are still a number of relations of the former Regent, and who through his removal are deprived of the best rice fields, and dessas, on which they lived in indolence, and whose discontent with the Landholder has already been very evident....

Besides this, the Landholder has dismissed a great number of Chiefs, who however they may have been in prosperity, are now feeling the want and means to maintain themselves, and their families; and who express the greatest dissatisfaction at the Chinaman Landholder of Probolingo.

The Regents themselves, he admitted, had proved hopelessly indolent and contributed little to the prosperity of the districts, and so the Chinese had withdrawn the desas and fields from their control. But the proprietors had introduced new taxes, and hardship had resulted. The best solution, Goldbach thought, was for the Government to remove the Chinese, and administer the country directly.

Goldbach wrote to Raffles on March 8, outlining in detail his idea of establishing European proprietors in the Oosthoek. "If the lands of ... Java's Oost[hoek] were the property of Europeans", he wrote, ${ }^{51}$ "it is most certain that they would be the source of great wealth". But he advised caution in disposing of them. Lands heavily populated should not be sold, and any peasants who suffered by the sale should be adequately compensated. The Regents, if they continued to be useful, should also be provided with a reasonable subsistence. "So long as the regents still remain, they could proportionably be indemnified for the loss of their revenues by the sale of grounds, in the paying of recognition money, and contingents, or they might receive a salary from Government, with [an] addition [of] some dessas, from whence they could have the people for their pomp and service; in which case the poll money,... the farm money,... and that which is paid by the Javanese to the regents out of the produce of the ground, could be collected by the drost or others". ${ }^{22}$ Goldbach admitted the dangers of European proprietorship

50 Goldbach to Hope, December 1, 1811, Java Public Consultations, March 7, 1812.

51 Goldbach to Raffles, March 8, 1812, Mack. Coll., (Pr.), Vol. 13, No. 6.

52 Loc. cit. 
in causing hardship to the people, as he had already had experience of the matter on the private estates in the Batavia Ommelanden. He thought it would be necessary, therefore, for the Government to establish regulations preventing oppression by the proprietors. Although Goldbach's advice did not have any influence on Raffles' decision to recognize Chinese proprietorship in the Oosthoek, as it did not reach him until some days after he had taken that decision, it apparently exerted some influence on his ideas about the question of dispensing with the services of the Regents and compensating them with parcels of land.

In reporting to Minto his recognition of Daendels' sale of Probolinggo, Raffles stated that he had taken the decision only after mature consideration.

In the course of my investigation into the transaction, I have by no means been inattentive to the serious arguments, and objections ... to the possession of so large a tract of land by one proprietor, a Chinese, but the present was not the only instance in which a similar grant had been made, and there did not appear any adequate ground for annulling so formal, and legal a sale, (which in one point of view might be considered as an experiment of Private Industry against the feudal system, which so generally exists throughout the Island) to be put in competition with the permanent advantage to be derived..$^{53}$

At the time of Raffles' decision to recognize the Probolinggo sale, $950,000 \mathrm{Rix}$ drs. were still in circulation on the security of the sale. If Raffles had repudiated the sale, he would not only have had to make arrangements for the withdrawal of this sum but would also have had to find compensation for the proprietor. Such a task, of course, was impossible, and so Raffles accepted the lesser of two evils. Lord Minto eventually approved the decision, reflecting that "this sale of public lands to a private purchaser is an approach at least towards a more general revolution in the tenure of landed

53 Raffles to Minto, March 7, 1812, Java Public Consultations, March 7, 1812. Italics mine. Compare Daendels' rationalization of the sale of Probolinggo. The native administration of the district, he wrote, "[was] a bar to any experiments being made in Husbandry, it being confirmed by experience that great and useful experiments in agricultural pursuits may be only expected from free, and unlimited possession". (Daendels to the Minister of Marine and Colonies, December 1810. I have followed an English translation in Java Public Consultations, March 7, 1812.) 
property, and a step in the transition so much to be desired from that vicious system which has so long shackled and repressed improvement by dependent and precarious possession in every district, and indeed, in every field or garden in Java, to that scheme of secure and independent property, the ameliorating powers of which display themselves so happily in every quarter of the world where it is enjoyed". 54

\section{The first Land Settlement - Bantam.}

Among the applications for leases and purchases of lands sent to the Government during the early months of 1812, was one forwarded through Yule, the Resident of Bantam. The application was for a decennial lease of land lying to the north of the Great Bantam Road, bounded on the east and west by the Tjikandi and Onderandir Rivers. Because the lands were "almost entirely in a state of nature", Yule had given some encouragement to the applicant, and had suggested that he make a definite offer to the Government for the lease. ${ }^{55}$ The members of the Council considered Yule's request on April 16, but resolved that although they were "desirous of throwing into the hands of private Industry a considerable portion of the waste or ill cultivated lands upon the Island", they could not decide on the matter until they had further particulars. ${ }^{56}$

Yule forwarded more information about the applicant some days later. The prospective lessee, it appeared, was a Chinese, who wished to extend sugar-cane cultivation in Bantam, and erect mills for its manufacture. He also wanted to establish a bazaar for the sale of his surplus, and hoped eventually to supply the Batavian market. Although he had offered only "loose and indefinite" terms, ${ }^{57}$ Yule asked whether the Government proposed to encourage "so industrious and productive a race" as the Chinese in Bantam. "Under the present Revenue System," he wrote, ${ }^{58}$ "I fear that Bantam will yield but little or nothing. The country of all others on the Island appears to me susceptible of the highest

54 Minto to Raffles, June 5, 1813, Ibid., October 15, 1813. Compare Minto to the Court, July 31, 1813, Bengal Political Letters Received, Vol. 10; and in Bengal Letters Received, Vol. 66.

55 Yule to Davidson, March 24, 1812, Java Public Consultations, April 16, 1812.

5 Java Public Consultations, April 16, 1812.

57 Yule to Blagrave, April 20, 1812, Java Public Consultations, April 22, 1812.

58 Loc. cit. 
degree of cultivation, and under proper regulations there is no doubt but a considerable revenue will be derived from it. I am little qualified, however, to point out improvements in this line, and only wish to have the sentiments of Government with respect to the propriety of granting (either to Chinamen or Natives) leases for fixed periods. And in what proportion to the annual produce the rents ought to be calculated in the event of such leases being agreed to."

The Government decided against accepting the Chinese application.

[T] he late unsettled situation of ... Bantam renders it ... unadvisable that the proposal should be accepted, the nature and oppressive character of the Chinese in general having so often been experienced in this Colony as the principal cause of disturbances and insurrections among the Natives, that the same consequences are to be dreaded from their settlement as proprietors of so large a tract of ground as is comprehended between the Rivers. ${ }^{58}$

The Government's objection to Chinese proprietorship was also transmitted to the Mackenzie Commission.

In the meantime, acting on instructions from Raffles, Yule had removed Pangeran Ahmat from Bantam, and established Sultan Bagus Mohamed, originally appointed by Daendels, in charge of the Highlands. ${ }^{60}$ His jurisdiction was limited to those districts, and two Regents were placed in control of the Lowlands. In effecting these measures, Yule attempted to avoid all appearances of introducing anything of a revolutionary change, and proceeded as if the decisions made were his own, and not those of the Government. ${ }^{61}$ After publicly restoring the Sultan to the dignities which he had enjoyed before Pangeran Ahmat's usurpations, Yule asked Raffles to fix the establishments and salaries of the two Regents of the Lowlands, and to suggest what proportion of the annual produce of the lands should be

58 Java Public Consultations, April 22, 1812.

i;) Pangeran Ahmat was a man of low birth, who had gathered many malcontents about him when Daendels appointed Bagus Mohamed to the throne. The Pangeran had afforded help to the British blockading fleet, and so received a pardon by the British Government. But his ambition was the sultanate, and he soon came into conflict with Yule.

(it Raffles to Minto, May 1, 1812, Java, Vol. 68. Another copy of this despatch is in Mack. Coll., (Pr.), Vol. 13, No. 7. 
collected for the Government. ${ }^{62}$ Raffles thought the favourable situation in Bantam now afforded "a fair occasion for making an attempt at a preliminary step towards the introduction of an Improved Tenure of Land and real property amongst the Inhabitants of Java". ${ }^{83} \mathrm{He}$ did not consider that he was bound to restore to the various relations of the last three Sultans of Bantam the whole of the property of which they had been dispossessed by Daendels and Pangeran Ahmat.

[But] as a new arrangement for the general Tenure of Land is desirable over the whole island, by which, instead of the feudal system under which the Regents hold their respective extensive districts, only an adequate portion of those districts should be granted them either in full property or a long lease, this mode of tenure of land may on the present occasion be tried in the Bantam Districts, and the Resident, Major Yule, be directed to report on the practicability of this measure and to propose a plan for the distribution of certain portions of land to the different Pangerangs and relations of the Sultans in recompense for the districts which they were possessed of formerly. ${ }^{64}$

Raffles was at last advocating a measure of reform which had already been hinted at in the Land Tenure Commission's instructions, and which Goldbach had advised him to adopt. This was to satisfy the claims of the Regents by grantirig them parcels of land, and to lease or sell the remainder to Javanese or European proprietors. For the moment, the Government did not specify what Yule was to do with the lands which would be left after he had made the distribution among the Pangerans and their relations.

As a prelude to the 1813 assessment, Yule seems to have been employed during most of 1812 collecting information about the districts under his charge. Nevertheless, during 1812 a rent in kind was collected in Bantam, although details about it are meagre. Raffles held out no hopes of great financial results from the first collections. He wrote to Minto in May 1812:

The general tranquillity and settlement [of Bantam] under European control is considered an object of sufficient impor-

62 Yule to Raffles, April 18, 1812, Java Public Consultations, April 22, 1812.

63 Java Public Consultations, April 22, 1812.

64 Loc. cit. The passage is cited Eindresumé, II, Bijlage A, 15; and Wright, H. R. C., "Muntinghe's Advice to Raffles....", op. cit., pp. 227-8. The above was a resolution of the whole Council, but it was undoubtedly Raffles' idea. 
tance to supercede at the present moment any view to immediate advantage, but altho' its present resources bear but a small proportion to its necessary expenses, there is every reason to expect that this extensive and fertile country, once reduced to order and system, will not only yield a revenue equal to its charge, but afford to the European Government a profit proportioned to that derived from other Districts of the Island. ${ }^{65}$

\section{Crawfurd on the Sultan's Territories.}

While Raffles was engaged in settling affairs in Bantam, he received from John Crawfurd, the Resident at Yogyakarta, a report entitled "Observations on the Nature and Resources of the Territories under the authority of the Sultan of Mataram". ${ }^{66}$ In this long and extremely competent document, Crawfurd gave Raffles his first authoritative information on agriculture and land tenures in Java. After describing the various methods of dry and wet cultivation, Crawfurd turned to the question of land revenues.

The taxes imposed on agriculture are of three different descriptions. The first is the rent of land, the second a sort of capitation tax levied on the husbandmen, and the third is nearly of the same description..., differing only in its name and amount.

Land Rent (Pajah): ${ }^{67}$ The extravagant prerogatives which the Javanese Princes seem long to have claimed, and the debasement which a course of ages has produced in the minds of the people, would at this day make any other notion of property in the soil, except that which ascribed it to the Sovereign, unintelligible. The Sovereign is the undisputed proprietor. He gives one day and takes back the following, and these vicissitudes are so common and the principle so thoroughly acknowledged, that there is not an acre of land in the country to which the shadow of hereditary right or title could be made. It is, perhaps, in this that the nature of landed

65 Raffles to Minto, May 1, 1812, Java, Vol. 68.

(ii) A copy is in Mack. Coll., (Pr.), Vol. 21, No. 4, but it is undated. However, Raffles sent a copy of the paper to Minto in his despatch of May 1, 1812, Ibid., in which he referred to it as "an excellent paper". It was, therefore, probably forwarded to Raffles by Crawfurd in April. Another copy is in Bengal Civil Colonial Consultations, January 8, 1814.

i7 Javanese Padjeg. This is not only one of the first references to the term "land rent" that Raffles saw, but the whole principle of "hiring" is contained in the term Padjeg. See Encyclopaedie van Ned.-Indië, II, 354, sub "Landrente"; Vollenhoven, C. van, Het Adatrecht van N.I., I, p. 553. 
tenure in Java differs more from that of Bengal, that the ancient authority of the Crown is less broken or diminished in Java, the sovereigns having contracted few obligations from their subjects. On this account, lands have never been given for life, as a reward for services, [thus] laying the foundation of perpetual and hereditary claims.

The whole rent of the lands of the country from property [is] the revenue of the Sovereign, though they do not come into his coffers in the shape of money. A system similar to the Jageer System which prevailed under the Mogul Dynasty of Hindoostan exists under the Government of the Javanese Princes to a much greater length. The noblemen of all classes have allotments of land according to the importance of their trust and employment. All the military are paid in the same way down to the lowest soldier, and even the menial and other servants of the Prince are thus paid, a salary or stipend being very seldom given in any case.

By far the largest proportion of the lands of the country are thus distributed, and the share which the Prince himself holds is inconsiderable.

Whether the Prince hold[s] the lands himself or they lie appropriated as now mentioned, they are most generally farmed to a class of people... under the denomination of Demans, Bukuls and Looras. There are few who farm their own lands; that class of people farm the lands to its peasantry at an advanced rate. It is probable that the office of these people is similar to that of the Zemeendars of India at their first institution before... the Mahomedan Government of that country had fixed the revenues, and... before the power of the Zemeendars themselves was extended by hereditary possessions of their offices. With these subjects, however, I profess to be unacquainted .... ${ }^{68}$

Those who hold immediately from Government usually receive their rent from the farmers in money. The farmers receive it from the husbandmen, sometimes in money and sometimes in kind, where in the latter manner, the usual terms are one half of the crop to the landlord.

The condition of the two last classes is but very indifferent, particularly the husbandmen. The farmers will generally make a profit on each [jung] of three or four Spanish Dollars. Even to enable them to do this they are forced to oppress the people

Italics mine. Crawfurd remarked earlier in his paper: "[T]here is a class of people above the labouring poor that deserve to be mentioned. These, according to the extent of their authority, are called Deman, Bukul or Loora. These men are in fact the Zimeendars of Hindoostan, stript of their hereditary claims." See pp. 118-9. 
who, generally speaking, can gain no more than a bare subsistence.

The same arbitrary conduct which the Sovereign observes to those who receive land from him is practised by those upon the Demans, Bukuls, and Looras, and these exercise the same privilege over the husbandmen. Leases are altogether unknown. $\mathrm{He}$ who gets possession today may be removed tomorrow. Instances of the greatest oppression and injustice originating in this System are of daily occurrence. They are carried to such a length that even the tameness of the Javanese is unable to submit to them, and bloody quarrels are the frequent consequence.

The fear of such results, and some attention to self-interest, appear the only bounds to the tyranny and exactions of the Javanese rulers. The rents are raised at pleasure and fines imposed on every trifling pretext.

Notwithstanding all this, and the indifference, sloth and indolence which such a state of society breeds, a stranger will be surprized to see the rich and fertile appearance of the Country, an appearance indeed, so flattering that it were no easy matter to convey an adequate impression of it. One may travel a hundred miles in this country, and hardly see anything but the most luxuriant cultivation. To the truth of this observation all who have visited Java will bear ample testimony. To account for so extraordinary an appearance, apparently contrary to all principle and experience, it should be remembered that the soil of the country is so uniformly rich and productive, that a man finds it here no difficult matter to provide for a family, that population has consequently increased rapidly, that new land must be necessarily cultivated for the subsistence of these new mouths, and that almost all the labour of the community is bestowed on the soil, because food is indispensable, and there is neither trade nor manufacturers which procure it from abroad.

Crawfurd went on to discuss the other levies imposed on the people, such as the tax on doors, and the contributions demanded for the up-keep of the roads. He concluded that the radical defect of the native administration was that "the labourer not only cannot be sure that he shall enjoy the fruits of his labour, but it is even certain that he shall be plundered of the greatest part of them. He has consequently little inducement to toil for more than a bare subsistence, and idleness makes him the stupid and indolent being which we observe a Javanese in common with all who live in such a state of society to be". The first step towards the improvement of the situation of the peasants, Crawfurd thought, was the granting of 
leases. In time, when capital had been increased, lands could be sold. He had in mind a permanent settlement of the revenue on the Bengal pattern. But he advised Raffles to proceed carefully if this course were adopted, because there was no class in Java who could make similar claims to proprietary rights to the soil as the Zamindars had done. With the security resulting from definite leases, the condition of the Javanese peasant would be much improved.

The fruits of his toil once secured to the labourer, we might reasonably expect rapid improvement in a country with so numerous a population, and where the necessity of providing for a family will soon become an additional spur to industry. It indeed deserves to be remarked that the operation of this last cause has within the memory of many people now alive increased to a surprizing degree the agricultural industry and skill of the Javanese, a circumstance which they themselves do not fail to observe.

Raffles was undoubtedly in receipt of Crawfurd's "Observations" before he ordered Yule to introduce a land lease system in Bantam, and there can be little doubt that it exerted a considerable influence upon his ideas on the question. If nothing else, it removed any doubts which he had regarding the rights of the Regents to their lands. Crawfurd's report convinced Raffles that the rights of the other Regents in Java could be treated in a similar way.

\section{Raffles suggests the Bantam Settlement for the rest of Java.}

On April 22, Raffles wrote to Mackenzie asking him to enquire among the Commission's members how far they thought the principles of the Bantam settlement could be applied throughout Java as a means of improving cultivation, and whether it was advisable to grant lands to the Regents and other chiefs in full property, or long lease, pending the final report of the Commission. ${ }^{69}$ When the query was circulated, the Dutch Commissioners showed some impatience at Raffles' continual pestering. Rothenbühler stated quite bluntly that he knew nothing of Bantam, and would have preferred to have arrived at some solution to the more general question relating to free trade and cultivation, before attempting an answer to the more

ny Raffles' letter to Mackenzie does not exist. Its contents can be gathered from a letter of Mackenzie's to Rothenbühler dated May 7, 1812. "Letter Book [of the] Commission", op. cit., Letter No. 9. 
specific query. Nevertheless, he thought that as the Regents were "in general little fit[ted] for the promotion of diligence 86 industry", ${ }^{70}$ there could be little objection to resigning to them and their families, and other principal chiefs, lands in propery, at least until their deaths. The Government could extend the grants to their heirs if it thought fit. The adoption of such a plan, Rothenbühler argued, would have the advantage of raising the Regent class from idleness by requiring them to take an active interest in their lands. The remaining grounds left after distribution to the Regents should be let or sold, preferably to Europeans, and thereafter sparingly "to such Natives of whose diligence one can be fully assured, as they are ... in general so lazy $\&$ indifferent that little good is to be expected of them in regard to the improvement of agriculture". ${ }^{71}$ Rothenbühler considered that the Chinese, being an industrious race, might have some lands sold to them, but not in great quantities because they oppressed the Javanese. Moreover, their "exorbitant thirst after wealth" could hardly encourage among the people those characteristics of diligence which Raffles had in mind. The Government should always have the right, Rothenbühler concluded, to transfer lands wholly or in part for services rendered.

Lawick van Pabst, in his reply to Raffles, reiterated Rothenbühler's objections to Chinese proprietorship, but stated that he knew nothing of Bantam, so could not offer anything specific in the way of an answer. ${ }^{72} \mathrm{Knops}$ apparently did not reply to Raffles' query.

\section{Raffles informs Lord Minto about Land Reform.}

The early months of the British administration of Java had been a busy time for Raffles. He had not only to master the intricate details of government in the Company's districts, but had also to conclude treaties with the Susuhunan and Sultan. ${ }^{73}$ The result was that he did not have time to tell his patron of his plans for land reform. In February 1812, Minto had written hinting that he would like to hear something on the subject. ${ }^{74}$

\footnotetext{
70 Rothenbühler to Mackenzie, May 30, 1812, "Letters read in Committee on the 12th August 1812", Mack. Coll., (Pr.), Vol. 35, No. 18, Letter No. 6.

71 Loc. cit.

72 Lawick van Pabst to Mackenzie, no date, Ibid., Letter No. 7.

73 Deventer, M. L. van, N.G., pp. 314-9.

74 Minto to Raffles, February 26, 1812, Raffles Collection, I, No. 14.
} 
At the end of January, Raffles had sent an estimate of the proposed revenues of Java, together with some other information to Bengal, but the arrival of Minto's February letter made him take time off to give his superior a full account of the changes which had been effected in the administration. This despatch of May 1, 1812, was one of the longest that Raffles ever wrote. ${ }^{75}$ In it he informed Minto of the measures taken by Yule to pacify Bantam, but he did not refer specifically to the instructions which had been issued on the subject of leasing lands. Instead, he enclosed the whole of the documents relating to the Bantam settlement. Unfortunately they never reached Bengal. ${ }^{76}$ Raffles did, however, enter fully into the question of the rights of the Regents with respect to their lands, and the subject of land tenure generally. The Dutch Company, he explained, had possessed the same rights as the Susuhunan and Sultan, who were regarded as "the ultimate Proprietors of the land" in their own territories. ${ }^{77}$ The Company had, therefore, drawn its revenues and services from the Regents, who in turn had been granted allotments of land. But their tenure was unstable, and Daendels had only theoretically strengthened their rights by issuing them with Government commissions. Raffles condemned Daendels' partial abolition of contingents such as indigo, cotton yarn and pepper, while at the same time he transferred to the Government the right to the extortions formerly practised by the Company's servants. But a measure more pernicious was "that by which the Native Regents were each of them subjected to a contribution in hard cash, while at the same time, the power of levying taxes on the inhabitants of their district was left in their hands." "It would be unnecessary to point out," Raffles continued, "... the source of iniquity and vexation which thereby was opened on the country, and though the dread of an arbitrary power above them, may have restrained the Regents from many an act of oppression to which they were induced by this arrangement, the measure itself seems no less essentially liable to censure". ${ }^{78}$ All these circumstances, Raffles concluded, made him look forward with "impatience" to the report of the Mackenzie Commission. Until that report was available he would reserve any further consideration on the various branches of

75 Raffles to Minto, May 1, 1812, Java, Vol. 68.

70 Bengal Civil Colonial Consultations, January 8, 1814.

77 Raffles to Minto, May 1, 1812, op. cit.

78 Loc. cit. 
the administration, and "in particular, in the Tenure and Regulation of landed property and cultivation, to which my attention has been so immediately directed by Your Lordship". ${ }^{78}$

\section{Continuation of Contingents and Forced Deliveries.}

Raffles' condemnation of Daendels' policy of granting commissions to the Regents, is hard to reconcile with his own actions. He had himself six months previously issued commissions to the Regents in the Jakatra and Preanger Regencies, ${ }^{80}$ and in a private letter to the Chairman of Directors in March, had actually praised Daendels' measures regarding the Regents. ${ }^{81}$ It is possible, perhaps, to explain the inconsistency if we remember that during April, Raffles had become more convinced of the justice and policy of removing the Regents, and compensating them with lands. But although this measure was consistent with Minto's wishes, ${ }^{82}$ Raffles remained content in his May despatch to hint at it, doubtless hoping that he would receive guidance on the matter from the Supreme Authorities. Because reform had to proceed slowly, Raffles told Minto that the system of forced deliveries and contingents would have to be continued, if a colonial revenue was to be expected. Thus, while Raffles criticized Daendels' collection of contingents in money, he nevertheless based his own budgets on the assumption that they would continue to be collected. "The Contingents in money and rice from the Sultans of Cheribon and the different Regents," he wrote to Minto early in June 1812, when he presented an estimate of receipts and disbursements for the financial year 1812/13, "may be considered as the permanent Revenues of the Island, \& calculated upon accordingly. The prosperous state of the Island and the favourableness of the season, added to the security afforded to the Inhabitants, enables these Chieftains to pay their Contingents without default". ${ }^{83}$ In an enclosed estimate, Raffles listed the following as the contingents which could be reckoned as forming part of the revenue

81 Raffles to the Chairman of Directors, March 19, 1812, Java, 67. The relevant passage in the despatch is cited by Wright, H. R. C., "Muntinghe's Advice to Raffles....", op. cit., 226; Lady Raffles, Memoir, 105.

82

83

Loc. cit.

Java Public Consultations, November 23, 1811.

See pp. $181-2$.

Raffles to Minto, June 5, 1812, Java, Vol. 60, Part II. 
for $1812 / 13 .^{84}$ Raffles, in fact, found the utmost difficulty in collecting them, ${ }^{85}$ and the arrears in payment continued to be made by the Regents long after the land rent system had been introduced. In order to give some sort of comparison, the contingents in money and kind, and the forced deliveries ordered by Daendels in 1809 are placed alongside. ${ }^{86}$

\begin{tabular}{|c|c|c|c|c|}
\hline \multicolumn{3}{|c|}{ RAFFLES } & \multicolumn{2}{|c|}{ DAENDELS } \\
\hline Rosents of & $\begin{array}{l}\text { Money } \\
\text { Sp. drs. }{ }^{87}\end{array}$ & Kind & $\begin{array}{l}\text { Money } \\
\text { Sp.drs. }\end{array}$ & Kind \\
\hline $\begin{array}{l}\text { TJIREBON } \\
\text { (the three Sultans } \\
\text { together) }\end{array}$ & 20,250 & $\begin{array}{l}1,650 \text { Koyans of } \\
\text { rice for nothing }\end{array}$ & 24,000 & $\begin{array}{l}1,000 \text { Koyans of } \\
\text { rice for nothing } 80\end{array}$ \\
\hline TEGAL & 5,063 & $\begin{array}{l}\text { 1,400 Koyans of } \\
\text { rice @ } 15 \text { Rix } \\
\text { drs. a Koyan }\end{array}$ & 5,400 & $\begin{array}{c}700 \text { Koyans of rice } \\
@ 15 \text { Rix drs. a } \\
\text { Koyan }\end{array}$ \\
\hline PEMALANG & 1,875 & $\begin{array}{l}375 \text { Koyans of } \\
\text { rice @ } 15 \mathrm{Rix} \\
\text { drs. a Koyan }\end{array}$ & 2,000 & $\begin{array}{c}250 \text { Koyans of rice } \\
@ 15 \text { Rix drs. } \\
\text { Koyan }\end{array}$ \\
\hline BREBES & $1,312^{88}$ & $\begin{array}{c}100 \text { Koyans of } \\
\text { rice @ } 15 \mathrm{Rix} \\
\text { drs. }\end{array}$ & 1,400 & $\begin{array}{l}50 \text { Koyans of rice } \\
\text { @ } 15 \mathrm{Rix} \text { drs. }\end{array}$ \\
\hline PEKALONGAN 88 & 6,750 & $\begin{array}{l}661^{13} / 17 \text { Koyans } \\
\text { of rice @ } 15 \\
\text { Rix drs. }\end{array}$ & 7,200 & $\begin{array}{l}300 \text { Koyans of rice } \\
\text { @ } 15 \text { Rix drs. }\end{array}$ \\
\hline
\end{tabular}

84 "Estimate of the Probable Receipts \& Disbursements of ... Java from the 1st May, 1812, to the 30th April, 1813", dated May 18, 1812, Java, Vol.60, Part II.

85 See p. 115.

86 I have taken these figures from an estimate made by the Accountant-General, Bauer, in April 1812, Bengal Civil Colonial Consultations, January 8, 1814. I have added various details from lists in Mack. Coll., (Pr.), Vol. 26, Nos. 3 \& 4; Vol. 38, No. 2; Java, Vol. 59; Sub., 178.

87 In this table Daendels' Sp. drs. are to be reckoned @ 60 Stivers; Raffles' @ 64.

88 This figure appears as 1,213 in the list in Java, Vol. 60, Part II.

89 In the list in Java, Vol. 60, Part II, the total of rice delivered from the Pekalongan to Kudus Regencies is given as 2,905 Koyans. The detailed figures above are taken from the list in Mack. Coll., (Pr.), Vol. 26, No. 4. The total comes to 2,898 Koyans, and together with 6 Koyans of rice from Adilangu not recorded in the Java, Vol. 60, Part II list, gives us a total of 2,904 Koyans.

90 The list in the Mack. Coll., (Pr.), Vol. 26, No. 3, gives this figure as 2,000 Koyans, which is more likely to be correct. 


\begin{tabular}{|c|c|c|c|c|}
\hline \multicolumn{3}{|c|}{ RAFFLES } & \multicolumn{2}{|r|}{ DAENDELS } \\
\hline Resents of & $\begin{array}{l}\text { Monoy } \\
\text { Sp.drs. }\end{array}$ & Kind & $\begin{array}{l}\text { Money } \\
\text { Sp.drs. }\end{array}$ & Kind \\
\hline BATANG & 3,750 & $\begin{array}{l}49611 / 34 \text { Koyans } \\
\text { of rice @ } 15 \\
\text { Rix drs. }\end{array}$ & 2,000 & $\begin{array}{l}125 \text { Koyans of rice } \\
@ 15 \text { Rix drs. }\end{array}$ \\
\hline SEMARANG & 586 & $\begin{array}{l}40 \text { Koyans of } \\
\text { rice @ } 15 \text { Rix } \\
\text { drs. }\end{array}$ & & \\
\hline KENDAL & - & $\begin{array}{c}100 \text { Koyans of } \\
\text { rice @ } 15 \mathrm{Rix} \\
\text { drs. }\end{array}$ & 22,934 & $\begin{array}{l}1,180 \text { Koyans of } \\
\text { rice @ } 15 \text { Rix drs. }\end{array}$ \\
\hline KALIWUNGU & 1,500 & - & & \\
\hline DEMAK & 5,625 & $\begin{array}{l}1,000 \text { Koyans } \\
\text { of rice @ } 15 \\
\text { Rix drs. }\end{array}$ & - & - \\
\hline DJAPARA & 4,219 & $\begin{array}{c}60 \text { Koyans of } \\
\text { rice @ } 15 \text { Rix } \\
\text { drs. }\end{array}$ & 4,500 & $\begin{array}{l}60 \text { Koyans of rice } \\
\text { rice @ } 15 \text { Rix drs. }\end{array}$ \\
\hline $\begin{array}{l}\text { PATI and } \\
\text { GLONGGONG }\end{array}$ & 5,625 & $\begin{array}{l}400 \text { Koyans of } \\
\text { rice @ } 15 \mathrm{Rix} \\
\text { drs. }\end{array}$ & 6,000 & $\begin{array}{l}385 \text { Koyans of rice } \\
\text { rice @ } 15 \text { Rix drs. }\end{array}$ \\
\hline DJUWANA & 1,875 & $\begin{array}{l}140 \text { Koyans of } \\
\text { rice @ } 15 \mathrm{Rix} \\
\text { drs. }{ }^{.1}\end{array}$ & $\begin{array}{c}2,350 \\
\text { including } \\
\text { Rembang } \\
\text { and } \\
\text { Glong- } \\
\text { gong }\end{array}$ & $\begin{array}{l}205 \text { Koyans of rice } \\
\text { rice@ @ } 15 \text { Rix dra. }\end{array}$ \\
\hline KUDUS & 1,407 & 一 & 1,500 & - \\
\hline SURABAYA & 10,312 & $\begin{array}{l}\text { Same as } \\
\text { Daendels }\end{array}$ & 11,000 & $\begin{array}{l}168 \text { Pikuls of } \\
\text { Gemuti thread, } \\
\text { half @ } 2^{3} / 4 \text { Rix } \\
\text { drs. \& half @ } 3 \\
\text { Rix drs. a Pikul. } \\
800 \text { cans of earth } \\
\text { oil for nothing } \\
1,000 \text { Koyans of } \\
\text { rice for nothing }\end{array}$ \\
\hline
\end{tabular}

91 Raffles estimated that the rice would be sold by the Government @ 30 Sp. drs. a Koyan; earth oil @ 5 Sp.drs. a can; green katjang @ 40 Sp. drs. a Koyan; and coconut oil @100\% profit on the 6 Stivers a can paid for it by the Government. 


\begin{tabular}{|c|c|c|c|c|}
\hline \multicolumn{3}{|c|}{ RAFFLES } & \multicolumn{2}{|c|}{ DAENDELS } \\
\hline Regents of & $\begin{array}{l}\text { Money } \\
\text { Sp.drs. }\end{array}$ & Kind & $\begin{array}{l}\text { Money } \\
\text { Sp.drs. }\end{array}$ & Kind \\
\hline GRESIK & 3,000 & $\begin{array}{l}\text { Same as } \\
\text { Daendels }\end{array}$ & 3,200 & $\begin{array}{c}75 \text { Pikuls of } \\
\text { Gemuti thread @ } \\
3 \text { Rix drs. a Pikul. } \\
180 \text { Koyans of rice } \\
\text { @ 15 Rix drs. a } \\
\text { Koyan }\end{array}$ \\
\hline LAMONGAN & 1,875 & $\begin{array}{l}\text { Same as } \\
\text { Daendels }\end{array}$ & 2,000 & $\begin{array}{c}25 \text { Pikuls of } \\
\text { Gemuti thread @ } \\
3 \text { Rix drs. a Pikul. } \\
220 \text { Koyans of rice } \\
\text { @ } 15 \text { Rix drs. a } \\
\text { Koyan }\end{array}$ \\
\hline PASURUAN & 2,813 & $\begin{array}{l}\text { Same as } \\
\text { Daendels }\end{array}$ & 3,000 & $\begin{array}{l}98 \text { Pikuls of } \\
\text { Gemuti thread, } \\
\text { half @ } 2^{3} / 4 \text { Rix } \\
\text { drs. \& half @ } 3 \\
\text { Rix drs. a Pikul. } \\
110 \text { Koyans of rice } \\
\text { for nothing }\end{array}$ \\
\hline BANGIL & 938 & $\begin{array}{l}\text { Same as } \\
\text { Daendels }\end{array}$ & 1,000 & $\begin{array}{l}36 \text { Pikuls of } \\
\text { Gemuti thread, } \\
\text { half @ } 2^{3} / 4 \text { Rix } \\
\text { drs. \& half @ } 3 \\
\text { Rix drs. a Pikul. } \\
43 \text { Koyans of rice } \\
\text { for nothing }\end{array}$ \\
\hline PUGER & 469 & - & 500 & - \\
\hline BANGKALAN & 6,487 & $\begin{array}{l}12,000 \text { cans of } \\
\text { coconut oil for } \\
\text { nothing }\end{array}$ & 6,000 & $\begin{array}{c}252 \text { Pikuls of } \\
\text { Gemuti thread @ } \\
2^{3} / 4 \text { Rix drs. a } \\
\text { Pikul. 12,000 cans } \\
\text { of coconut oil for } \\
\text { nothing, \& 2,000 } \\
\text { cans@ } 6 \text { Stivers } \\
\text { a can } \\
\end{array}$ \\
\hline
\end{tabular}




\begin{tabular}{|c|c|c|c|c|}
\hline \multicolumn{3}{|c|}{ RAFFLES } & \multicolumn{2}{|c|}{ DAENDELS } \\
\hline Regents of & $\begin{array}{l}\text { Money } \\
\text { Sp.drs. }\end{array}$ & Kind & $\begin{array}{l}\text { Money } \\
\text { Sp.drs. }\end{array}$ & Kind \\
\hline PAMEKASAN & 2,775 & $\begin{array}{l}7,500 \text { cans of } \\
\text { coconut oil for } \\
\text { nothing }\end{array}$ & 2,000 & $\begin{array}{l}65 \text { Pikuls of } \\
\text { Gemuti thread, } \\
\text { half @ } 2^{3} / 4 \text { Rix } \\
\text { drs. \& half @ } 3 \\
\text { Rix drs. a Pikul. } \\
7,500 \text { cans of coco- } \\
\text { nut oil for nothing }\end{array}$ \\
\hline SUMENEP & 6,563 & $\begin{array}{l}200 \text { Pikuls of } \\
\text { Gemuti thread, } \\
\text { half @ } 2^{3} / 4 \text { Rix } \\
\text { drs. } 8 \text { half @ } 3 \\
\text { Rix drs. } 17,500 \\
\text { cans of coconut } \\
\text { oil for nothing, } \\
82,000 \text { cans @ } \\
6 \text { Stivers a can. } \\
80 \text { Koyans of } \\
\text { green katjang } \\
\text { for nothing }\end{array}$ & 7,000 & $\begin{array}{l}252 \text { Pikuls of } \\
\text { Gemuti thread, } \\
\text { half @ } 2^{3} / 4 \text { Rix } \\
\text { drs. \& half @ } 3 \\
\text { Rix drs. a Pikul. } \\
17,000 \text { cans of } \\
\text { coconut oil for } \\
\text { nothing, } 852,000 \\
\text { cans @ } 6 \text { Stivers } \\
\text { a can }\end{array}$ \\
\hline SIDAYU & 4,688 & $\begin{array}{l}\text { Same as } \\
\text { Daendels }\end{array}$ & 5,000 & $\begin{array}{c}50 \text { Pikuls of } \\
\text { Gemuti thread @ } \\
3 \text { Rix drs. a Pikul. } \\
270 \text { Koyans of rice } \\
\text { @ } 15 \text { Rix drs. a } \\
\text { Koyan }\end{array}$ \\
\hline BAWEAN & - & $\begin{array}{l}\text { Same as } \\
\text { Daendels }\end{array}$ & - & $\begin{array}{l}6 \text { Pikuls of Gemuti } \\
\text { thread, half @ } \\
2^{3} / 4 \text { Rix drs. \& } \\
\text { half @ } 3 \text { Rix drs. } \\
\text { a Pikul. 2,500 cans } \\
\text { of coconut oil @ } \\
6 \text { Stivers a can }\end{array}$ \\
\hline BANJUWANGI & - & $\begin{array}{l}\text { Same as } \\
\text { Daendels }\end{array}$ & - & $\begin{array}{l}12 \text { Pikuls of } \\
\text { Gemuti thread @ } \\
3 \text { Rix drs. a Pikul. } \\
50 \text { Koyans of rice } \\
\text { for nothing }\end{array}$ \\
\hline TUBAN & - & - & 1,600 & $\begin{array}{c}60 \text { Koyans of rice } \\
@ 15 \text { Rix drs. a } \\
\text { Koyan }\end{array}$ \\
\hline LASEM & - & - & 3,100 & - \\
\hline
\end{tabular}




\begin{tabular}{|l|c|c||c|c|}
\hline \multicolumn{2}{|c|}{ RAFFLES } & \multicolumn{2}{c|}{ DAENDELS } \\
\hline Regents of & $\begin{array}{c}\text { Money } \\
\text { Sp.drs. }\end{array}$ & Kind & $\begin{array}{c}\text { Money } \\
\text { Sp.drs. }\end{array}$ & Kind \\
\hline WIRADESA & - & - & 2,000 & $\begin{array}{c}100 \text { Koyans of rice } \\
\text { @ 15 Rix drs. a } \\
\text { Koyan }\end{array}$ \\
\hline $\begin{array}{l}\text { Chinese farmer of } \\
\text { ULUJAMI }\end{array}$ & - & - & 4,980 &. \\
\hline
\end{tabular}

At the beginning of 1812 , as we have already seen, Raffles expected to derive large profits from the coffee culture. He had estimated at the end of January that these profits would average about $25 \% .^{92}$ However, in presenting his financial estimates in the following June, he wrote: ${ }^{83}$

The large quantity of Coffee which has been thrown upon the market in consequence of the capture of the Mauritius and Java, added to the state of commerce in Europe, precludes this Government from calculating with any degree of certainty on this hitherto important source of Revenue which in favourable seasons has been known to throw into the Treasury of Java a clear profit of not less than two millions of Spanish Dollars in the year. The price paid to the cultivators... does not exceed three Spanish Dollars the picol, while the sale to the Americans and others was made at from 18 to 20 Spanish Dollars per picol, faster than the crop could be gathered.

Raffles hoped that when the glut had ceased, coffee would find an advantageous market at the Company's sales in England. But without calculating any profits from a peace-time disposal of coffee, or from the sale of spices, which he still hoped would be handled through Batavia, he placed the Java receipts at the ridiculously high figure of 5, 278, $373 \mathrm{Sp}$. drs., and the disbursements at only 631,032 Sp. drs. ${ }^{94} \mathrm{He}$ told Minto that there would be no need for the Java Government to draw bills of credit on Bengal during the ensuing

92 Raffles to Minto, January 29, 1812, Java Public Consultations, February 1, 1812.

93 Same to same, June 5, 1812, Java, Vol. 60, Part II.

94 Loc. cit. 
financial year. ${ }^{95}$ It was this rash promise, later transmitted to the Secret Committee, ${ }^{96}$ which caused Raffles unnecessary trouble later. Minto, of course, welcomed the news, although he cautioned Raffles on his January estimates, pointing out that only a defective collection of the revenue could be expected during the first year of the occupancy of Java ${ }^{97}$ But, he continued, "the evident capacity for improvement which is observable throughout that extensive country encourages a confident hope under the existing Government, that the Island will gradually yield increasing Revenues to the State". ${ }^{98} \mathrm{He}$ agreed in all the circumstances, that there could not be any justification for the Java Government drawing further bills on Bengal.

It was into this impossible position that Raffles had talked himself by the middle of 1812 . Before many weeks had passed, the failure to collect adequate revenues either from articles of export, or from the internal resources of the island, forced him into a drastic programme of reform. There was, besides Minto's instructions for a general reform, the urgent necessity to produce an internal revenue adequate to carry on the administration, and to pay the military forces. There were many ideas current in Java about how the economic system of the island should be reformed, and it is to these that we must now turn our attention.

95 Loc. cit.

96 The above despatch to Minto, together with the financial estimates, was forwarded to the Secret Committee on October 26, 1812, Java, Vol.60, Part II.

97 Minute by Lord Minto, July 4, 1812, Java, Vol. 60, Part II.

98 Loc. cit. 


\section{IDEAS ON REFORM}

\section{Hope, Muntinghe and Goldbach.}

On February 21, 1812, the Java Council considered a letter from H. Hope, the Civil Commissioner for the Eastern Districts. It related to persons desiring pensions from the new Government. Hope thought that a way of satisfying these claimants would be to grant them allowances of rice, coffee, salt and other colonial produce from the Government stores, together with small sums of money to procure other trifling comforts. He concluded:

As the revenue would suffer most essentially by doing away [with] the present system of retailing from the Government Storehouses, because while exportation is so limited, our internal consumption is almost the only mode of disposing of the produce received as Contingents, or as Monopolies by Government, the issue of small quantities [to] pensioners will not produce any additional Establishment. It can be performed by the Establishment already existing in the Storehouses. ${ }^{1}$

The Council expressed surprise at Hope's use of the word "present" to describe the system of retailing from the Government stores, as no orders had been given for such trade. Hope was asked to explain the matter.

Hope's reply was a sensible and convincing argument for the continuation of the system of contingents and forced deliveries. ${ }^{2}$ The quantity of contingent rice delivered annually in the Semarang districts alone was 2,100 koyans, he explained, and sales there were made at three times the original cost. He thought that the E.I.C. would lose considerably if this system of retail were abolished. Further, although the quantity of spices, coffee and other colonial

1 Hope to Raffles, February 12, 1812, Java Public Consultations, February 21, 1812.

2 "Report of Mr. Hope on the Retail System in the East Point of Java", March 9, 1812, Mack. Coll., (Pr.), Vol. 13, No. 9. The Report was addressed to Raffles. The following quotations come from this Report. 
produce consumed on the island was not great, what little there was yielded profits of $300 \%$. On the question of the coffee culture in the Eastern Districts, Hope wrote:

The whole of the trouble of the introduction of the coffee plant is now over, 86 the trees having been planted some time, $\&$ beginning in all places to bear fruit, the inhabitants have lost the antipathy \& horror in which they held its introduction, \& the whole expense \& trouble which now remain are a few Overseers at 20 Spanish Dollars a month to see that the gardens are kept clean.... However small the returns of the sale of coffee may be, it will cover those expenses, 8 the only expense which remains to Government is the original cost of the coffee, the sale of one fifth of which, at the usual price of exportation covers the whole of the expense of Government, \& the remainder in store is so much profit. The coffee being good $\&$ fresh, there is every reason to suppose that Government will be able to dispose of it to advantage at some future period by the command of the India market, \& of the probable change of affairs in Europe; whereas by a contrary method the revenues of Government must suffer most severely.

If the coffee gardens were sold, the valuable monopoly of the produce would be lost, and the Government would have to enter the market as a competitor with private individuals. Moreover, the existing glut of coffee would result in low prices being offered for the gardens.

If a person does purchase a coffee garden, it is with the positive expectation of being able by the bargain to undersell the Company even considerably, as he must be aware that he could not otherwise enter into competition with the Company; 8 consequently the whole consumption of the Island must fall into the hands of the purchasers with the first external commerce of the Island, \& Government, already obliged to reduce its price, will have all their coffee purchased at the usual rate remaining on their hands, except what they have been able to dispose of in coming second in the market.

The proposition of selling the whole of the coffee gardens must follow the objections of disposing of only a part of them, \& the propriety of selling the immense extent of ground which those gardens cover must previously come under consideration, particularly when from the nature of its produce no adequate price can possibly be expected which could anyhow compensate to Government for alienating so large a tract of valuable ground. 
After considering Hope's arguments, the Government decided on March 24 to continue "provisionally" the existing system. ${ }^{3}$ It seems certain that it was Hope's outspoken views, together with the reluctance of the Mackenzie Commission to suggest an immediate method of reform, which convinced Raffles at this time that the contingent system would have to be continued. Raffles passed on Hope's report to Muntinghe for his opinion, and on May 27, the latter presented a long reply. ${ }^{4}$

Muntinghe argued that even if the system of monopoly were more profitable with certain articles of commerce, especially coffee, that did not mean that monopoly should be preferred to one of free trade and cultivation. Thinking of Nederburgh and the 1803 Commission's Report, Muntinghe wrote:

The principal objections made to the introduction of a system of free trade and free cultivation on this island, have been drawn from the indolence of the Javanese, the difficulty of satisfying the native chiefs and Regents under such a system, and the total subversion of order, peace and tranquillity which was represented as a consequence thereof.

To the first objection, he argued that if a person were "deprived of every prerogative, of a right of property, and of every prospect of ameliorating his situation" he would naturally be indolent and impoverished. But if he were granted the right of property, and shown the way to improvement, then he would "display the principles and faculties innate to every human being". Muntinghe thought that the greatest difficulty to be overcome would be arranging compensation for the Regents and the chiefs under such a system. He suggested the following solution.

From the favour which formerly prevailed in giving them any preferment, and from the arbitrary sway which they experienced in the latter instance under the French government, the whole class of these Regents must be deeply impressed with a sense of their precarious situation, and consequently they must be inclined in favour of a permanent settlement, if any such could be made for them.

This settlement, now, I think, it would not be impossible

3 Java Public Consultations, March 24, 1812.

4 Java, Vol. 71, and Mack. Coll., (Pr.), Vol. 13, No. 10; Wright, H. R. C., "Muntinghe's Advice to Raffles....", op. cit., pp. 230-6. 
to make in a manner acceptable to the Regents by granting them in full property, and free from all contributions in kind or in money, for themselves and for their heirs to come, such a portion of the districts now under their control as would yield them a yearly revenue more than equal to their present income - stipulating at the same time that in future they should have no right to levy for themselves any taxes in kind or in money in any other parts of their former territories, but that in compensation of the permanent possession granted to them of their estates, they should be obliged to continue in the same duties of police which they performed before as Regents, and that their next heirs, capable of holding the situation, should always be preferred in case of any vacancy. ${ }^{5}$

If such an arrangement were practicable, there would be no serious obstacles to the introduction of a system of free cultivation and free trade. As the Regents would be restricted under the new system from levying taxes, contingents and other charges outside their estates, these would have to be collected by the Government. There could be no objection in principle to the rights of the Government in proceeding with such a change, since the treaty with Mataram in 1749 had transferred all notions of real property of the land to the Company. Muntinghe continued:

Acting from these principles, Government will instantly perceive and collect all the duties and taxes now levied in cash by the Regents; it may alter, diminish or increase the same as circumstances may require; it may substitute one or more general heads of taxation in lieu thereof, or in any case regulate them and bring them under a system the least oppressive to the community.

In the same manner, Government will enter on the immediate perception on her own account of all the contingencies and other contributions in kind now levied and perceived by the Regents. It may order new surveys in every district, regulate, increase or diminish those contributions accordingly and as it will be found just and equitable.

In the meantime, the Government might from time to time, as the demand warranted it, dispose of parts of these domains, either on short or long leases, or by selling them, on the condition that a proportion of the crop, payable either in kind or money at the option

5 Loc. cit. 
of the possessor, should be delivered yearly to the Government as a rent.

In that manner, the yearly revenues of Government will naturally and insensibly increase with the increasing industry of the cultivator, animated by a more permanent right of possession and by a free disposition of the remaining part of his produce.

He thought that during the first period of the new system, the amount of contingents and contributions in kind might even exceed that yielded under the old system. But soon afterwards, the effects of the introduction of private property, or the security offered by leases, would be felt, and with free trade "it is naturally to be expected that a large proportion of the rent due to Government on the leases granted will be paid in cash instead of in produce, and then probably the period will be near that all the remainder of the contingencies and contributions levied in kind, as far as they are not wanted for the immediate use of Government, may be disposed of by public auction at stated periods, and that thus a new prospect may be opened for private industry and commerce, while at the same time the greatest part of [the] public storehouses, storekeepers, overseers and writers belonging to those establishments may be dispensed with". Until this period, or a time when an increase of trade would produce an adequate circulating medium for the payment of regular wages to the Javanese, Muntinghe advised that only a partial reform be attempted. The whole of the feudal services rendered by the Javanese should be continued, together with the deliveries and contingents in kind, and instead of a permanent settlement with the Regents, the inferior chiefs should be granted portions of rice fields only so long as they remained in office.

Thus the whole of the native establishment and administration might be preserved under the introduction of a system of free trade and free cultivation, and no dangers as to the public peace and tranquillity seem to be threatened by it.

With regard to the coffee cultivation, Muntinghe tended to agree with Hope. He thought it would be useless transferring the coffee gardens to the Javanese because of their aversion to the culture. 
The plantations would soon be in ruins. There was no alternative, therefore, but to continue the monopoly system or to sell the coffee plantations to Europeans in full property. If the latter course were adopted, there would be objections raised to the use of Javanese on the private estates. He considered the best way would be to assign the lands in full property to Europeans, but to continue the existing system of enforcing on each Javanese and his family the cultivation of a certain number of coffee trees. ${ }^{\beta}$ Wages could then be paid either for the quantity of coffee produced, or for the labour rendered. Regulations would have to be established to protect workers on the estates, and accurate surveys taken of the lands which were to be sold. These particulars should then be published and forwarded to the London and Calcutta Exchanges, at least twelve months before the sales.

If these proposals were considered feasible by the Mackenzie Commission, Muntinghe thought the comparative advantages of such a system of free trade and cultivation might be estimated in the following manner.

The present revenues and expenses should be first ascertained, and then on the other hand should be calculated: 1st. The continuance of all contingencies of rice and other articles as long as they do not find an ample compensation in money.

2nd. The continuance of feudal service on public occasions for the same period.

3rd. The continuance of the opium farms just as before.

4th. The Custom House duties considerably increased, on account of the increase of trade and cultivation.

5 th. An additional duty of $3 \%$ on the exportation of articles formerly belonging to the monopoly.

6th. A poll tax at least equal to the double of the present contributions of the Regents.

7th. A land tax at the rate of $1 / 2 \%$ on a capital of at least five millions of Spanish Dollars.

8th. An additional duty of two or three per cent on the transfer and collateral succession of the same capital.

9th. Five millions of Sp. D[rs.] calculated for the sale of coffee plantations, the crop being calculated at 100,000 peculs, on the whole island.

(') Daendels' regulation, which ordered each family to care for 1,000 coffee trees, was still in force in the Batavian and Preanger Regencies. 
And

10th. The reduction in every public department occasioned by the abandoning of the monopoly calculated at [?] Spanish Dollars. ${ }^{7}$

Muntinghe's programme of reform was based upon suggestions contained in the instructions issued to the Land Tenure Commission. His views on the sale of coffee gardens were, however, influenced by Minto's instructions to Raffles.

The idea of distributing parcels of land to the Regents in compensation for losses sustained in the introduction of a new system of cultivation, was now gaining ground in Java. There was still some disagreement about the means of effecting the measure. Goldbach wrote to Mackenzie on May 23, 1812, advising caution with regard to the Regents if the "feudal" system were abolished. "It is true," he wrote, ${ }^{8}$ "that General Daendels proclaimed the Regents to be employees [of] the Government, but this was accepted by very few .... [They] considered their [Regencies] as their property, and in consequence, the Javanese as their subjects". Goldbach, as we have seen, was no supporter of the Regents - "they are of stupid, lazy, haughty and libertine dispositions" ${ }^{\circ}$ - but he understood the danger to be apprehended from a sudden subversion of their status. He thought the best solution was to grant them lands, but not in full property. To prevent any disorders that might result from a disposal of lands to Europeans, Goldbach advised that Daendels' and Janssens' policy of creating Ommelanden of private estates about Surabaya and Semarang should be continued. This policy could then be extended to Gresik, Pasuruan and other towns in Java.

Knops and Lawick van Pabst's Report "Java as it is, \& as it may be".

The members of the Mackenzie Commission had separated on April 7 to investigate the districts of Java allotted to them. Rothenbühler had collected the material for his report on Surabaya by the end of May, ${ }^{10}$ although he did not write it until seven months

7 I have followed the Mack. Coll., (Pr.), Vol. 13, No. 10, copy of Muntinghe's Report. It differs in minor points from that published by Dr. Wright.

* "Letter from Mr. [P. A.] Goldbach ... to Lieutt. Colonel C. Mackenzie.... Suggestions 8 Notices on the Present State \&s proposed Improvement of the Resources, Revenues \& Condition of Java", May 23, 1812, Mack. Coll., (Pr.), Vol. 13, No. 8.

O Loc. cit.

10 Rothenbühler to Mackenzie, May 30, 1812, "Letters read in Committee on the 12th of August 1812", op. cit., Letter No. 6. 
later. ${ }^{11}$ Knops, in the meantime, was busy preparing a report on Demak and Djapara. Mackenzie himself had left Surabaya on April 22, and had travelled through Tuban, Lasem, Rembang, Djuwana, Pati, Kudus and Demak to Semarang, where he arrived on May 4. During his journey he had hastily attempted to confirm the facts in the various reports which had been sent in either by European or native officials. ${ }^{12}$ Mackenzie spent a busy month at Semarang with the affairs of the Commission, for he planned to leave for Batavia in June, and bring the work of the Commission gradually to a close. Raffles, who was anxious to hear of Mackenzie's views on the question of reform, readily assented to this proposal. What was to be the final meeting of the Commission was held at Semarang on June $3 .^{13}$ But before Mackenzie could depart for Batavia, troubles occurred at the Courts, and his services were required in the military operations against Yogyakarta. In order to facilitate the work of the Commission, Raffles had brought with him to Semarang translations of many of Daendels' administrative regulations, together with statistical queries which he had circulated, and various reports received in answer. Mackenzie wrote later that these documents had proved of great service to the Commission. ${ }^{14}$

At the end of June, during Mackenzie's absence at Yogyakarta, Knops and Lawick van Pabst had handed directly to Raffles a long report entitled "Java as it is, \& as it may be". ${ }^{15}$ From this Raffles learned more about the subject of the land tenures of Java, particu-

11 Rothenbühler, F. J., "Rapport van den staat en gesteldheid van het Landschap Sourabaija....", Verh. Bat. Gen. van Kunsten en Wetenschappen, (1881), Vol. XLI, pp. 1-70.

12 "Report of the President....", op. cit.

13 "Minutes of the Committee....", op. cit., June 3, 1812.

14 "Report of the President....", op. cit.

15 "Java zo als het is en zo als het kan zyn - Java as it is, 8 as it may be". The original Dutch copy is in Mack. Coll., (Pr.), Vol. 56, pp. 489. I have followed the somewhat shorter English translation entitled "Summary of a report, on the State of Java, by Messrs Knops \& van Pabst", Mack. Coll., $(P r$.$) , Vol. 24, No. 1. An even shorter version is in Ibid., No. 2. Deventer,$ S. van, L.S., I, 211, wrongly ascribed the authorship of the report to Lawick van Pabst and Rothenbühler. Raffles cited from the report in Sub., pp.126-30; and $H$. of J., I, pp. 141-3.

In a private letter to Mackenzie, dated July 13, 1812, Knops apologized for sending the Report directly to Raffles, without first consulting him, but excused hirnself on the grounds of Mackenzie's absence at Yogyakarta. Knops to Mackenzie, July 13, 1812, Mack. Coll., (Pr.), Vol. 74, No. 42. 
larly of the limitation to the notion that the rights of property were vested in the Sovereign.

"Throughout the whole extent of the Batavian Regentships...", Knops and Lawick van Pabst wrote, "[there] exists pretended property on uncultivated lands. Each dessa has a certain district of these uncultivated lands, where, however, no person may settle without the consent of the inhabitants of that dessa.

In the sawa fields, or cultivated lands, every inhabitant, from the Regent down to the lowest rank, has a share and may act with it in which manner he pleases, either sell, hire out, or otherwise dispose of it, and loses that right only by leaving the village in a clandestine manner.

In the Province of Cheribon, according to the ancient constitution, each district \& dessa, like the Regencies under Batavia, has its own lands, with that difference, however, that whilst those of Batavia are considered as belonging to villages or individuals, here the villages and lands are altogether the pretended property of the chiefs, or of the relations or favorites of the Sultans who even might dispose of the same, with an exception, however, of that part allotted to the common people. Sometimes the Sultans themselves were the owners of dessas \& chiefs of the same, in which case the inhabitants were better treated than in the former instances. If an individual thought himself wronged by his chief, who either sold, hired out or otherwise disposed of his land, he took his revenge, not on the chief, but on the person who held possession of the property."

On the other hand, they continued, no person along the North East Coast could be regarded as a proprietor either of the sawahs or any other lands. "The whole country belongs to government, $\&$ in this light do all the Regents consider it".

After an examination of the actual state of Java, Knops and Lawick van Pabst turned their attention to a method of improving cultivation. Adopting a liberal line, they denied that the Javanese was a lazy, dissembling creature, and argued that even if he were, the reason was to be found in the monopoly conditions enforced by the Dutch Company. They thought that a policy of free trade was bound inevitably to lead to prosperity. "It is an established maxim with the most enlightened statesmen", they maintained, "that restraint in culture and commerce tends to the ruin of that country where it is enforced, and Java fully corroborates the same". The 
main point of their programme of reform was the "colonization, or... making a transfer of lands to individuals, with liberty to cultivate the same, according to their own free will \& judgment". The transference of lands was to be made by sales, which were to be extensive, covering most of the island. These were to be open to Europeans, Javanese, and all foreigners, with the exception of the Chinese. The following conditions, which Knops and Lawick van Pabst laid down for the sales, show what they had in mind.

1. The purchaser of lands becomes entitled to the enjoyment of all taxes and levies formerly paid to Government by the inhabitants. He may lessen the same, but not augment them. 2. He may make advances upon the crop, but shall conform to the regulations [on] interest which Government may be pleased to make. We are aware... that these advances were prohibited ... which was requisite for the sake of great abuses existing at that time. It has, however, been very prejudicial to cultivation, for which reason we propose that it may be again permitted, supposing that every land-owner who requires an advance of paddy for seed knows his interest well enough to determine whether he ought to take it on the conditions it is offered to him or not.

3. The proprietor of the land shall have the right to compel the people to cultivate their ricefields adjoining the villages with such articles of produce as the season, local situation and circumstances shall admit of, and he may deem most profitable. 4. He shall have no authority to deprive any person of his share in the sawa-fields, but may prefer his complaint against those who are careless in [cultivating] them.

5. If he wishes to cultivate those lands which hitherto lay barren, he shall come to an agreement with the people for their work, and reward them either with a share in the produce or with money.

6. The number of chiefs which he may find on the Estate at the time of his becoming proprietor of it, he shall keep, and leave them in the enjoyment of those prerogatives which are granted to them by the regulations. In case one of these is remiss in his duties, the land-owner may complain, and if such a chief be deposed, or in case one happens to die, he may chose another with the concurrence of the Regent, and approbation of the local authority, from amongst the inhabitants of the village to which the former belonged.

When we speak of the proprietors keeping the chiefs we premise that all those that are considered to be superfluous, will be dismissed previous to the sale of the lands.

7. The proprietor shall be at liberty to appoint a Great- 
Mandoor or Surveyor over his Estate whom he may charge with the administration of it. This person will be dependent only on the proprietor, who is obliged, however, to advise the local authority if he were to make a change.

8. The Great-Mandoor is paid by the proprietor, who shall have no authority to allow him a share in the sawa-fields; yet he may assign to him that part of the uncultivated land with which that person may act in the same manner as the proprietor with his own.

9. If a person neglects the cultivation of his land, he shall be deprived of it....

10. All the fruit trees of a campong are the property of the inhabitants.

11. The chiefs and inhabitants are subject to the native Regent as far as concerns public duties, marriages and inheritances, according to regulations that may be made hereafter.

12. The inhabitants of private estates remain subject to public duties and the delivery of horses $\&$ buffaloes for the service of Government, either without payment or for such reward as may be regulated for the people on unsold lands.

13. No proprietor of an Estate shall be at liberty to dispose of the water that is requisite to cultivation....

14. If a proprietor finds it necessary to make water-courses, ditches or drains on the lands of the common people for the benefit of cultivation, they shall be obliged to perform that work without payment....

15. It shall be permitted to the land-owner to make use of the buffaloes, horses, pedatties or carts, of the inhabitants within the limits of his Estate for a reasonable payment, and if they consent, he may also employ them for transport \&rc.

16. He shall not, however, have any claim on the cattle or carts of the people for his services, although he were to offer payment, if they are to perform their own work.

With regard to the coffee plantations, Knops and Lawick van Pabst thought that the following conditions should be established:

A. The purchaser of one or more coffee plantations shall be obliged to receive from each family attached to that culture the produce of 1,000 trees.

B. He is to pay Sp. Drs. 3 for 200 lbs. [of] clean coffee. What he rejects, remains at the disposal of the people, or may be kept by him at half the price, and if any dispute on that account were to happen, the same shall be decided by the local authority.

C. The coffee shall be delivered at the places thereto appointed at present, yet the proprietor may engage the people to carry it elsewhere for a moderate payment. 
D. He is also at liberty to make such other agreements in that respect with his inhabitants to which they voluntarily shall accede.

E. If a family happens to be possessed of more than 1,000 fruitbearing trees, the purchasers of the land shall have no authority to deprive them of the surplus, unless that family is wanting the means to cultivate them properly.

F. A new plantation ought to be laid out as near the Dessas as possible, yet the proprietor of the Estate shall not force the inhabitants into that measure. As long as a family has 1,000 flourishing coffee trees, and it does not appear that in 2 or 3 years hence, the present plantations will be unable to afford a supply, no alteration shall be made.

G. The proprietor is at liberty to take possession of the lands where coffee formerly was planted, and convert them to his own use.

Because of the limited amount of specie in circulation, they proposed either that the lands should be sold by instalments, as in Probolinggo, or that they should be disposed of at moderate rates, and the Government should continue to levy "a land-tax on produce or a rent". During the period before the sales, the Government was to levy a tax on the produce of the lands. This was also to be levied on the unsold lands. "For the sake of avoiding trouble and inconvenience, as well as the uncertainty of the crop"; they wrote, "we might incline to recommend a land-tax; but knowing it to be the intention of Government that the new regulations should be as much as possible consistent with ancient usages, we have preferred a levy on the produce to the land-tax. The former [existed] for ages, the latter would be a novelty". All other taxes and arbitrary levies were, therefore, to be abolished, and the Government was to introduce a capitation tax. This, together with the tax on produce, was to be collected by special officers appointed for the purpose, to be called Collectors and Deputy Collectors. The former were to be in charge of several Regencies, while their Deputies were to superintend the collections of the capitation and produce taxes in one Regency only. As a method of improving cultivation, the Collectors were to be authorized to make advances on the crops.

Knops and Lawick van Pabst paid special attention to the position of the Regents in their new system. They were, in general, to remain the chief officers in their districts, but were to be shorn of their real power. Those not required in the administration were to be compensated with lands while those who were retained 
were to be treated in a similar way to the purchasers. They were, however, to retain their police powers, and be responsible for the good order of their districts.

Finally, free trade was suggested. "If no particular reasons are prevailing [to] the contrary", they wrote, "we would propose free trade \& navigation to be permitted from all ports and places on this Island to other foreign parts, as it cannot but tend to general advantage. To a permission of that kind the inhabitants will have the justest claim, as soon as free culture has been admitted of, in order that they may find means to export such articles of produce as in their opinion might be turned to a favorable account at a foreign market".

Raffles found much that was interesting in this report, and later, as we shall see, adopted certain of its recommendations. He accepted Knops and Lawick van Pabst's findings about land tenure in the Batavian Regencies and $T$ jirebon. But like them, he thought that the claims made by the people in those districts constituted only a "pretence" to property, and did not invalidate the general proposition outlined by Crawfurd that theoretically the Sovereign possessed the rights of free disposal throughout the island. Knops and Lawick van Pabst's report found Raffles in a generous mood, for on July 22 he attached clerks to the Commission, and granted travelling costs to its members. Mackenzie to his annoyance, was still refused a personal salary for his work on the Commission.

\section{Christiani's Advice.}

In the meantime, Raffles had forwarded Hope and Muntinghe's opinions on the question of introducing free trade and cultivation to Diederik Christiani. Although Christiani had little experience of affairs in Java, he showed wisdom in cautioning Raffles against any hasty disposal of lands to individuals. He believed that a system based on monopoly was "hateful $\&$ averse to the liberty of the subject", ${ }^{16}$ and thought that one of free trade was preferable. But he considered that the times were not ripe for such a startling change. The Government might control the export of rice to avert famine if the sawahs were sold, but other than this, it could hardly in justice regulate the disposal of produce from these lands. In the existing circumstances, therefore, he thought a continuation of the system of

Christiani to Raffles, July 31, 1812, Mack. Coll., (Pr.), Vol. 13, No. 12. 
rice contingents, rather than the levying of a money tax, would best serve the needs of the Government. So far as the coffee and pepper cultures were concerned, Christiani pointed out that as there was no market in British India, Europe or America, a sale of the gardens would be unwise. "I am ... of opinion," he concluded, ${ }^{17}$ "that it is not now either practicable or advisable to sell or even to attempt the sale of the coffee plantations, nor could I wish a free trade to be granted in coffee, pepper \& spices until a change in the political relations of Europe were to take place. Until then, therefore, the retailing trade may be turned to the best advantage that is possible".

\section{Rothenbühler's Report.}

On July 26, 1812, Mackenzie asked Rothenbühler to submit a report on his investigations to satisfy Raffles' impatience for a programme of reform. ${ }^{18}$ After a curt acknowledgment of Mackenzie's letter, Rothenbühler produced a long report on August $6 .{ }^{19} \mathrm{He}$ began this with a devastating criticism of the system of native government in Java.

The Regents, Rothenbühler said, were a great burden to the ordinary man because instead of fulfilling their obligations to consider the welfare of their districts, they acted under the impression that they themselves were the actual owners of the lands. Their extortions were copied by their subordinate chiefs, with the result that the original levies were increased beyond the point where the Javanese could meet them. In the Surabaya districts alone, the people had to pay eight regular taxes, which left little for their own sustenance. In addition, there were the arbitrary demands which often caused greater hardship than the regular taxes. The involved native administration in the Regencies meant that the European authorities never heard of oppressions, and could never persuade the people to come forward with their complaints. He admitted that the Javanese looked upon their chiefs with veneration, but said that

17 Loc. cit.

18 Mackenzie to Rothenbühler, July 26, 1812, "Letter Book [of the] Commission", op. cit., Letter No. 13.

19 There are two Dutch copies of this Report in the Baud Collection, (Rijksarchief, The Hague). No. 1,002. I have followed the English version in Mack Coll., (Pr.), Vol. 24, No. 3, entitled "Report of Mr. Rothenbühler a Member of the Commission at Sourabaya, Translated from the Dutch". 
they well knew that "the Sovereign alone is the rightful Lord of the Land, who has the power to take those Regents out of their situation if necessary". The existing system of administration was very disadvantageous to the Government, and served no other use "than to furnish to a number of lazy Regents $\&$ their attendants 86 family \& other chiefs, the means of living in luxury". The endless oppressions were most harmful to cultivation, and therefore, to the welfare of the colony. "It is in consequence more than time", Raffles was told, ". . . that an end is put to this monstrous system of Government. Humanity looks forward with pleasure to this step, [and] Government has the fullest right to it, whose interest it is particularly [to affect]".

Rothenbühler contended that no mere reform of the existing system would be satisfactory. What was wanted was a sweeping reform on the following principles:

i. The Regents and chiefs to be divested of their power.

ii. Full property in the ground to be established throughout the island, with free cultivation and free trade.

iii. Forced labour, deliveries and contingents to be abolished.

iv. The Javanese to be allowed "a proper degree of freedom and good treatment".

Recalling Nederburgh's opposition to van Hogendorp's proposals, Rothenbühler wrote:

I know very well, that many persons of understanding differ in opinion with me on this subject, 8 affirm that the introduction of such a total change if not impossible, is at least most dangerous \& difficult in execution. In the different arguments they produce to support their opinion, they principally count the attachment of the Javanese to his Regent $\&$ other chiefs, \& his detestation of everything not agreeable to the old customs, $\&$ the regulations made by his fathers.

This would be a sufficient objection, if it were true, but this was not the case.

[H] owever great the respect of the Javanese may be for his Regent \& chiefs, \& how[ever] little the [possession] of education permits him to complain against his superiors, the many removals to other places..., prove at least this much, that he wants not the hearty desire to see himself delivered from such a severe government not to occasion a tumult when 
this change shall be made, when he sees that Government has no other intention in the introduction of such a total change, but to prevent in future his being continually oppressed.

Rothenbühler admitted that there were difficulties to be faced, but these should not be over-rated in the present case where there was such an "absolute necessity" to establish a new system of cultivation. The dismissal of the Regents would not cause much trouble judging from Daendels' experience. Nevertheless he advised that their removal should not be effected too suddenly, for "perhaps the common Javanese by want of penetration of the real intention...., following the nature of all slaves \& oppressed people, would not have confidence enough in what Government would tell him..., 8 would possibly take up the idea that this change would be extended to his religion, morals \& customs". The dismissal of the Regents should, therefore, begin slowly in those districts where there were towns and forts, because in such places it would be easier to convince the people of the necessity of the step. Compensation should be afforded the Regents in grants of land. These should be large enough to yield a yearly revenue of between 2,000 and 3,000 Rix drs. for an Adipati; 1,000 to 2,000 Rix drs. for a Tumenggung, and so on down to the Mantris, whose lands should give them a yearly revenue of from $\mathbf{4 0}$ to $\mathbf{8 0} \mathrm{Rix}$ drs. The remaining chiefs would have to fend for themselves, as they had when the Probolinggo lands were sold by Daendels in 1810 . Full property rights should not be conferred on the Regents. The Government, instead, should reserve its right of increasing or decreasing the amounts to the relations when a Regent died. Such grants of land to the Regents, would have the advantage "of making a great number of lazy people employ themselves for the improvement of the Commonwealth, because their subsistence from the public being taken away, they will be obliged at least to watch over the good cultivation of the lands allowed to them, $\&$ to treat their subordinates in a friendly $\&$ just manner, in order to prevent their running away, by which they would lose the greatest part of their subsistence". An alternative to this arrangement would be to give the Regents the above sums in cash. But he thought this solution would not have the same advantage of making them into an active class of cultivators. In the remaining lands, the Government was to introduce property in the soil, and grant freedom of cultivation.

Rothenbühler contended that it would be necessary to sell these 
remaining lands in full property, otherwise the Government would have to administer the districts itself, and this could only be done through the Regents. Lands, of course, might be leased, but this would occasion much trouble since they would all have to be surveyed - an impossible task. Besides, leases would result in fresh abuses on the part of the lessees, who would not have a true interest in the lands and their population. "[E]ach man is more or less ruled by his passions $\&$ desires", he said, " $\$$. . . every man does not think equally delicately about the means of satisfying them".

At the same time that lands were sold to individuals, it would be necessary to establish free trade (except opium) and cultivation. Rothenbühler did not think lands should be given to the Javanese, because of the difficulty of dividing them among the peasants. Besides, the Javanese possessed no capital, and very little stock to work the lands. They were, moreover, indolent.

I am convinced that if once the Javanese has land in his possession $\&$ is left to himself without any restriction, he will not work any more than is absolutely necessary for him \& his family, whose wants are besides of very little consequence - a poor bamboo house covered with ... leaves, a handkerchief \& some few cloths for him \& his wife, \& a small quantity of rice or Turkey-corn boiled in water, with some vegetables, \& sometimes a small quantity of fish, this is all ... he wants. Lazy by nature, \& effeminate by education, the Javanese seems only to exist to live in indolence, occupying himself ... by sleeping or sitting alongside a river, contemplating the current of the water, or if he is inclined, taking some fish for his dinner without ever feeling the desire to ameliorate his fate by work.

Under these circumstances, Rothenbühler thought that lands should be sold only to Europeans. Some few parcels might be granted to those Javanese "whose good conduct \& activity" demanded recognition. But they would have to find their own capital to make purchases of the lands.

Rothenbühler advised a slow disposal, the Government first making certain that the European purchasers possessed enough surplus capital to develop their estates. He thought that the coffee gardens in the Eastern Districts should be sold, except those in Banjuwangi which were under cultivation by convicts. The djati forests and their desas should be reserved for the use of the Govern- 
ment, although some of the poorly timbered lots should be sold. After two years, the salt-pans, birds'-nest rocks, pearl fisheries and sugar-cane fields should also be disposed of, if suitable offers were made for them. The bazaars and tollgates, on the other hand, were to be reserved by the Government, and farmed out yearly to the highest bidder.

In order to secure good prices for the lands, Rothenbühler advised that they be sold by public auction, and prices kept high by selling in small lots, every two or three months. Any unsold lands might then be farmed to the Javanese, on condition that they could be withdrawn and sold at a future date. He thought that these lands should be farmed to the Petinggis, who were elected by the villagers. ${ }^{20}$ This would save the Government the necessity of dividing the lands among the people, and the Petinggis could simply act under the magistrates and drosts. The Petinggis should collect from the inhabitants of the villages:

i. $1 / 2$ of the rice harvest on good lands, and $1 / 3$ on the others. This could be received in money, if necessary.

ii. The same proportions of other produce planted in the place of rice, but this to be accepted only in money.

iii. $1 / 3$ of the produce of second crops, to be paid in money.

iv. $1 / 3$ of the profits from the forests, fishing-places, $8 \mathrm{rc}$. to be paid in money.

v. A Poll Tax to be regulated according to the circumstances of the people, but to be generally reckoned at $4 \mathrm{~J}$. Rs. p.a. for each family who occupied $1 / 4$ of a jung of land. A family possessing less than this amount of land was to pay $2 \mathrm{~J}$. Rs. p.a., and those who possessed only fruit trees $1 \mathrm{~J}$. R. p.a.

Rothenbühler thought that in the Kampongs situated near the towns, whose inhabitants were engaged mainly in trade, a general Poll Tax should be levied, ranging from $4 \mathrm{Sp}$. drs. p.a. for merchants, goldsmiths and so on, down to $1 \mathrm{Sp}$. dr. for the common man.

In connection with the sale of lands to Europeans, Rothenbühler advised Raffles to lay down the following conditions:

1. Purchasers to have proprietary rights forever, with freedom of disposal.

2. Purchasers to have freedom of cultivation, except the opium poppy.

20) See p. 157. Rothenbühler stated the same fact in his "Rapport van den staat en gesteldheid van het Landschap Sourabaija....", op cit., 16. 
3. Purchasers to have a free sale of produce.

4. Purchasers to have the right to make new roads on their lands.

5. Purchasers to have full rights to establish markets and bazaars on their lands.

6. Purchasers to have the right of subdivision of their grounds among the Javanese on the estates.

7. The people to be subject to the proprietors in all matters of justice but the proprietors not to be given the right of punishment, this to be left to the magistrate.

8. The proprietors to have the right to force the Javanese to cultivate the pieces of land allotted to them, provided the work allotted be not excessive.

9. The proprietors to have the right to exact private services from the people on the estates for the conversion of waste lands into cultivated areas, and so on. Such services, however, only to be rendered by men between the ages of 18 and 50, and calculated on the basis of the rice fields allotted to them. The proprietors only to use the Javanese praus, cattle \&c. if paid for.

10. The proprietors to have the right of levying a yearly Poll Tax on the inhabitants on their estates. This Tax to be regulated by law.

11. The proprietors not to remove chiefs from their estates, but these chiefs, including the Regents, to have no jurisdiction over the Javanese, unless the proprietors specifically allow this.

12. The proprietors not to establish monopoly conditions on their estates, the people to have the right of disposing of any surplus produce. All coffee, however, to be delivered to the proprietors at a payment of $4 \frac{1}{2} \mathrm{Rix}$ drs. per pikul of $225 \mathrm{lbs}$.

13. The proprietors not to have the right of preventing the Javanese from appealing to their priests to settle disputes, nor to interfere in their religious customs.

14. The proprietors to keep all public roads \&c. on their estates in good order. Proprietors to have the right to demand the necessary services from the people under their charge for this work.

15. The proprietors to provide victuals \&6c. for Government troops passing through their lands.

16. The proprietors to furnish all coolies, horses, carts \&c. for the transport of troops, any payment rendered by the Government to be distributed among the peasants called upon for service.

17. The proprietors to provide all labour for the Government's use in erection of public works on a similar basis. 
Under these conditions, Rothenbühler thought that all the former forced deliveries, contingents, and services should cease. However, if the Government wished to purchase some of the produce from the private estates this could be arranged by a contract. He suggested that the new system of proprietorship should be introduced into the western part of the island, except Tjirebon and Batavia, which he left for Knops and Lawick van Pabst's consideration. It could then be extended gradually into the rest of Java.

\section{Mackenzie's Report.}

Rothenbühler's report was submitted to Mackenzie in Dutch. There was some delay in having it translated, and Raffles did not receive a copy until October 2. In the meantime, on August 11, Mackenzie had prepared a report of his own, in which he outlined the proceedings of the Commission. This interim report ${ }^{21}$ contained no ideas for a reform of the system of cultivation, only the dogmatic assertion, soon to be usefully employed by Raffles, ${ }^{22}$ that the proprietary rights to the ground in Java were vested in the Sovereign.

"From every source of enquiry I could personally refer to", Mackenzie informed Raffles, "it has been constantly reported by natives as well as Europeans that the right of Property has been invariably considered solely in the Sovereign or State. This reply has been given in the Districts of the Native Chiefs where no sale of lands is permitted, $\&$ in the territories of the European Government, the same prevailed until of late years to the Eastward... which I introduce only to remark that excepting these partial sales of late years by the Colonial Government, the sale of lands do not appear to have been practised or known to the Native Government in the East of Java, at least since the introduction of the Koran ....

Whether any other System prevailed antecedent to that great change is not known, nor necessary perhaps to be known altho' some knowledge of the previous institutions might explain several difficulties that occur. The very terms \&s names used of officers \& divisions, of Patties, Adi-Patties, Dessas, Negries \&cc. might indicate a Hindoo origin; but at the same time when we find the universally received Hindoo method of subdividing a province or country in lesser divisions

21 "Report of the President....", op. cit.

22 Raffles cited the passage given in the text in his Minute of June 14, 1813. Sub., pp. 257-9. I have followed the manuscript copy, which differs in one or two minor respects from the passage cited by Raffles. 
\& ultimately into villages divided into little communities whose members possess a common right of occupancy, is not practised, nor its attendant mode of marking with religious precision the limits of every village by permanent landmarks, we are apt to look to another source. These are subjects that require a particular \& tedious investigation. At present it appears that in the countries referred to, I mean particularly the provinces East of Cheribon denominated the East Coast of Java, it has been the practice from time immemorial, as they assert, to commit the management of the lands \& cultivation to the Adi-Patties or Tomagongs (denominated Regents by the Dutch) who accounting to the Sovereign for the stipulated supplies, whether in money or in kind, [were] left to assess the quantities levied on the cultivators at pleasure, whether of money or produce. This, at least, seems to have been the practice that prevailed in the provinces subject to the European Government, where, whether from indolence or any other motive, the whole of the details have been thus left to the native administrators, whose mode of assessing them on the lands and natives do not seem to have been ever much enquired into, until the situation of the Island became an object of enquiry of the late Government.

I will only add, that these lands thus estimated \& committed to the management of the Tomagongs, were by them parcelled out, \& considerable portions, or Jonks, transferred to all the officers employed, from the highest to the lowest classes, in proportion to the nature of their office, in lieu of salary. But it did not hence follow that these lands were cultivated by the persons to whom they were transferred, who appear to have resorted in most cases to an intermediate description, who made it their business, \& hired laborers \& other persons occasionally in the different branches of agricultural occupation - the reaping $\&$ taking in of the crop particularly devolving on the women. This practice of paying the officers of the Government, of the detailed management, \& even the military, in lands, is stated in different districts to have prevailed from time immemorial... But it must be confessed that notwithstanding the supreme $\&$ exclusive property of the soil recognized in the state or sovereign, undoubtedly strengthened by the tenets of the Mahomedan Law, yet a certain right \& pretension arising from occupancy $\&$ prescription appears to have been respected among the natives $\&$ even protected by some of their institutions in certain cases, as in the productions $\&$ fruits of trees planted by the lower cultivators about their dwellings. The protection of these people on that soil which their ancestors had cultivated \& inhabited, \& the consequent increase of cultivation $\&$ of produce, was looked on as the 
peculiar distinction of a good Sovereign, \& hence a law of custom, or Addat, was recognized, which seemed to protect them in the occupancy of the ground \& from being unnecessarily removed from the land occupied by their families. As the protection of the useful body of cultivators will naturally be an object not only of humane consideration with a British Administration, but of real importance in a political view, I doubt not but the future condition of these people will be an object of attention, in whatever plan is followed, \& under any possible transfer of property."

We shall return later to consider the exception allowed by Mackenzie in the general notion of proprietary rights, and its influence on Raffles' ideas. For the moment it is important to notice that Mackenzie's statement on land tenures made a deep impression on Raffles, confirming as it did the findings of Crawfurd and others. Raffles based his land rent Minute of June 14, 1813 upon Mackenzie's conclusions, and cited the above passage at length in Article 9 of the Minute.

\section{The Mackenzie Commission and the Sale of Lands.}

Mackenzie remained at Semarang until August 18, when he departed for Batavia. ${ }^{23}$ During his journey he attempted to hasten the preparation of the statistical tables in the coastal Regencies. Before he left Semarang, he arranged a method of communication which was to operate between the members of the Commission, but although the Commission continued to function until the early months of 1813 , its members never met together as a body to tonsider their findings.

When Mackenzie arrived at Batavia at the end of August, he heard that detachments of the 89th Regiment were about to leave for Madras, and he sought Raffles' permission to leave with them. ${ }^{24}$ But the postponement of the sailing orders, and Raffles' persuasive coaxing, made him decide to remain on Java until he had brought the Commission's work to a close. He was engaged fully in that task until he departed for India a year later.

23 “Report and Journal... of Lieutt. Colonel Mackenzie....", op. cit. There was a final meeting of the Commission called for August 12, at Semarang, but there was a poor attendance. "Minutes of the Committee....", op. cit., August 12, 1812.

24 "Report and Journal ... of Lieutt. Colonel Mackenzie....", op. cit. 
By the middle of August 1812, Knops had completed a report on Semarang, ${ }^{25}$ including Demak, Ungaran, Salatiga and Boyolali, and had also forwarded information regarding Pekalongan, Kendal, Kaliwungu and Ambarawa. ${ }^{28}$ During that month, he was investigating Rembang and Lasem, and intended continuing his surveys in Djuwana, Pati and Kudus. ${ }^{27}$ At the same time, Lawick van Pabst was busy in Tegal, and Rothenbühler, who was ill, was completing his report on Surabaya.

Raffles, meanwhile, had forwarded Mackenzie's report, the Minutes of the Commission, and the List of Queries circulated by it, to Bengal. ${ }^{28}$ This was meant to suggest to Minto that he had the matter of reform well in hand. He did not inform his Lordship, however, that he was contemplating a sale of lands about Semarang and Surabaya. On September 15, he gave orders to the Deputy Civil Commissioner, the Magistrate and Deputy-Accountant at Surabaya, and the Resident, the Magistrate and Deputy-Accountant at Semarang, to form a Committee, and survey the lands which had previously been investigated by the Mackenzie Commission, with a view to their disposal. ${ }^{29}$ The members of the Commission were also instructed to give their assistance in the task.

"Provisional or Abridged View of the Regency of Samarang and of its Dependencies", Mack. Coll., (Pr.), Vol. 79, No. 2. The French original of this report is in Mack. Coll., (Class), Vol. XIV, No. 25. Raffles cited the passage regarding the land tenures of Semarang in Sub., pp. 130-2. "There is not, to my knowledge, a single Javanese, who supposes that the soil is the property of the Regent; but they all seem to be sensible that it belongs to Government, usually called the Sovereign amongst them, considering the Regent as a subject, like themselves, who holds his district and authority from the Sovereign". Ibid., 130. Loc. cit.

Raffles to Minto, August 15, 1812, Bengal Civil Colonial Consultations, March 19, 1814.

28 Java Public Consultations, September 15, 1812. 


\section{THE SALE OF LANDS}

\section{The Deteriorating Finances of Java.}

The conquest of Java had been undertaken by the British Government only with the grudging support of the Directors of the E.I.C. While there may have existed some commercial reasons for the conquest of the Moluccas, there were none motivating the invasion of Java. Minto's orders were explicit. ${ }^{1} \mathrm{He}$ was to defeat the DutchFrench forces, reduce their fortifications, and depart, leaving the island to the mercy of the inhabitants. Minto's disobedience of these instructions, "because morally, impossible", 2 evoked little enthusiasm from the Directors, although his accounts of the riches of Java ${ }^{3}$ tended to smooth the ruffled sentiments of the commercial gentlemen of Leadenhall Street.

During the period of his administration of Java, Raffles was likewise forced to exaggerate the resources of the colony, in the hope that the Company would decide eventually to take permanent possession of the island. At the worst he thought it would become a crown colony. Raffles' wildly exaggerated estimates of the finances of Java in January and June of 1812 , as we have already seen, were welcomed in Bengal. The Supreme Government had suffered a severe run on its Treasury because of the Java expedition, so that the arrival of Raffles' June estimates convinced the AccountantGeneral and Minto that there no longer existed any necessity for the colonial Government to draw bills on Bengal. ${ }^{4}$ Unfortunately, Raffles' estimates did not accord with the true facts of the financial

1 Secret Committee to Minto, August 31, 1810, Deventer, M. L. van, N.G., pp. 4-5, footnote 1 .

2 Minto to the Secret Committee, December 6, 1811, Ibid., 6.

3 See, for example, Minto to the Secret Committee, October 5, 1811, Bengal Secret Letters, Vol. 13; same to same, October 18, 1811, Bengal Letters Received, Vol. 61.

4 Minute of Minto's, July 4, 1812, Java Public Consultations, November 4, 1812. 
situation, especially those relating to the continued depreciation of the paper currency.

Since a paper money had first been introduced into Java in 1782, its value had continually declined. By 1807 it was estimated that a depreciation had occurred of something like 80 to $100 \%$. Daendels had ordered another issue of paper notes on the security of the silver reserves of the Orphan Chamber, and there was a further issue in 1810 after the sale of the estates in the Oosthoek to the Chinese." At the time of the British conquest, a total of 85 lacs of Rix drs. paper was in circulation, made up of $4 \frac{1}{2}$ millions of Government paper, and 4 millions of Orphan Chamber notes, both amounts with a discount varying between 50 and $100 \%$. Lord Minto in a proclamation of September 11, 1811, officially recognized the paper at its depreciated value, establishing it at a ratio of $61 / 2$ Rix drs. paper to $1 \mathrm{Sp}$. dr. silver. ${ }^{6}$ Despite this official recognition, the paper continued its downward course during 1811 and 1812, and caused Raffles considerable anxiety. The depreciation was caused partly by the want of an export cargo, ${ }^{7}$ and partly because a large portion of the Government's disbursements had to be made in silver, ${ }^{8}$ which had the effect of undermining the official recognition of paper. By August 1812, a depreciation had occurred of from 80 to $90 \%$ on the rates established by Minto in the previous year, and by November the discount was generally more than $100 \%$. In an attempt to meet this serious situation, Raffles had suggested to the Bengal Government in the middle of August that the whole of the depreciated paper should be withdrawn, and a fresh quantity reissued guaranteed either by the Government directly, or by a Colonial Bank, for which he asked permission to establish. ${ }^{9} \mathrm{He}$ also requested that he might draw another 200,000 to $300,000 \mathrm{Sp}$. drs. in bills on the Supreme Government, in expectation of exports of

5 See p. 30 .

(i The proclamation is in Gillespie Charges, pp. 142-3, where further information on the subject of the paper currency can be found.

7 The balance of trade continued to remain unfavourable throughout 1813, Raffles to the Secret Committee, June 30, 1813, Java, Vol. 60, Part III. Raffles had lost one valuable source of revenue through the abolition of the opium monopoly in Java early in 1812. Minto to Raffles, February 28, 1812, Raffles Collection, I, No. 15; same to same, May 15, 1812, Java Public Consultations, September 17, 1812.

\& Mainly to the colonial troops. Gillespie Charges, pp. 2; 83; 215.

* Raffles to Minto, August 15, 1812, Bengal Civil Colonial Consultations, February 27, 1813. 
teak, arrack and coffee being made either to India or Europe. ${ }^{10}$ These proposals were eventually dismissed by the Supreme authorities early in the New Year, on the grounds that Raffles' earlier estimates had led them to believe that further demands on the Bengal Treasury would not be necessary. ${ }^{11}$ In the meantime, Raffles received Minto's despatch of July which prohibited the drawing of further bills on the Supreme Government. ${ }^{12}$

Immediately prior to its receipt, Raffles had to face another awkward situation when two of the Company's ships laden with British manufactures for sale in the island, arrived from Europe. The Court had instructed him to dispose of the cargoes for silver, ${ }^{13}$ but because of the scarcity of bullion he had suggested that payment should be made by a bill of credit to Bengal on the guarantee of a disposal of Java produce, including Banca tin, at Canton. ${ }^{14}$ Raffles had estimated earlier, that the export of tin from Banca would yield to the Java Government a yearly sum of 1,000,000 Sp. drs., but the value of the production of tin during the British administration never reached anything like that figure. Raffles' other commercial speculations in the China market, Japan and the Archipelago were based on equally disastrous calculations. Nevertheless, the want of an export cargo suitable for Europe, and the distress caused by the disappearance of the American ships, did not deter him from continuing to describe to the Directors at home the bountiful resources of Java. He outlined extravagant notions of shipping English woollens to China via Batavia, and through Amoi, and exaggerated the size of the Java market for the disposal of British cloths. ${ }^{15}$ In October 1812 he was given the opportunity to prove his statements, and he had hardly finished reading the Court's instructions regarding the disposal of the cargoes, when Minto's injunction prohibiting the issue of further bills of credit on Bengal arrived. In order to overcome the grave financial crisis which confronted the colonial Treasury, Raffles resolved on the somewhat drastic expedient of selling lands, with the ultimate intention of withdrawing the depreciated paper currency from circulation.

10 Loc. cit.

11 Minto to Raffles, February 27, 1813, Ibid.; Gillespie Charges, 149.

12. Java Public Consultations, November 4, 1812.

13 Court to Bengal, March 6, 1812, Despatches to Bengal, Vol. 58; also in Java Public Consultations, November 24, 1812.

14 Raffles to Ramsay, Secretary E.I.C., October 24, 1812, Java, Vol. 60, Part I.

15 Raffles to the Chairman of Directors, October 29, 1812, Java, Vol .60, Part II. 
Raffles had first suggested a partial sale of lands to Minto as early as January $1812,{ }^{16}$ but had received no reply to his suggestion. He had, however, Minto's original instructions regarding the disposal of the coffee gardens when enough capital had accumulated in the island for successful investment, and Minto's views on this subject had become fairly general knowledge in Java. During 1812, the Government had received many applications for the purchase of lands, and these had been forwarded to the Mackenzie Commission for consideration. ${ }^{17}$ Early in 1812 the members of the Commission had investigated the lands about Semarang and Surabaya, ${ }^{18}$ which Raffles thought should be sold, and in their reports later in the year had recommended wholesale disposals throughout the island, as a method of improving cultivation. Raffles had hesitated about accepting these recommendations because they appeared too revolutionary, and because he still had hopes that Mackenzie's final report would contain some less drastic expedient to meet Java's financial ills. Nevertheless when he was forced to sell lands in November, he became reconciled to the decision, according to Muntinghe, on consideration that it was "in perfect unison with the ideas occasionally delivered" by Mackenzie himself on the subject, and "not less with the views entertained and manifested by the Right Honorable the Governor General during his Lordship's stay on the Island". ${ }^{19}$ So that although the decision to sell lands was taken

16 Raffles to Minto, January 29, 1812, Java Public Consultations, February 1, 1812. Raffles later justified his sales on the grounds that the Supreme Government had raised no objection to his proposal. Gillespie Charges, 2. But in his despatch of January, Raffles had only suggested a partial sale, so that the silence of the Bengal Government on the question could hardly have been taken as approval of his decision to dispose of lands in large quantities.

17 The various applications for land are recorded in "Letter Book [of the] Commission", op. cit., and in "Letters read in Committee on the 12th August 1812", op cit.

18 See p. 25.

10 Muntinghe to Raffles, March 20, [1814], Enclosure No. 20, Gillespie Charges, pp. 31; 35. See also Mackenzie to Blagrave, May 8, 1812, "Letter Book [of the] Commission", op. cit., Letter No. 10; and Letter No. 17, Mackenzie to Assey, October 15, 1812. In his Minute of November 4, 1812, in which Raffles stated the reasons which made a sale of lands imperative, he wrote: "[T]he sale of lands to the extent required may be readily made in the Batavian Regencies, and in the Environs of the Towns of Samarang and Sourabaya - where, according to the opinion of the [Mackenzie] Commission... such [a] sale will be not only safe, but moreover beneficial to the future interest and situation of the Colony in general". Java Public Consultations, November 4, 1812. 
because of an "absolute and exigent [financial] necessity", ${ }^{20}$ Raffles thought that the sales would be "beneficial to the future interests and situation of the Colony in general". ${ }^{21}$ The reports of Lawick van Pabst, Knops and Rothenbühler, which had advocated a sale of lands as the necessary foundation for a system of free cultivation and trade in Java, had had their effect upon Raffles.

Raffles decided to dispose of large quantities of land at a special meeting of the Council held at Buitenzorg on November 4, 1812. The meeting was called to discuss the injunctions of the Supreme Government, and to consider remedies for the serious financial situation which those injunctions aggravated. It so happened that only Muntinghe and Raffles attencled the meeting, ${ }^{22}$ but despite what has been written to the contrary, Gillespie's absence from Council was nothing out of the ordinary, as he did not attend Council meetings regularly. He was, moreover, immediately informed of the decision to dispose of large parcels of land, and he eventually, though reluctantly, concurred. Cranssen agreed more readily. ${ }^{23}$ At the meeting, Raffles and Muntinghe discussed various ways of withdrawing the paper currency, and the different suggestions were set aside one by one. As Muntinghe wrote later: ${ }^{24}$

The means of withdrawing the amount in circulation might have been either to purchase it on account of Government in the Market, or to draw Bills on the Supreme Government to that amount, or to establish a Bank, by whose intercession such an operation might have been effected, or to institute a

20 Gillespie Charges, pp. 2; 81.

21 Ibid., 82.

22 Much has been made by Dutch historians of Raffles' corruption as a motive for the sales - his desire to purchase a large estate for his own profit. (De Haan, F., Priangan, I, "Personalia", pp. 287 et seq.; Klaveren, J. J. van, The Dutch Colonial System in the East Indies, (1953), pp. 92-4; and so on.) Although I do not justify the sale of lands, and think Raffles' participation in the sales a most foolish act, I cannot accept corruption as a motive for the decision to sell lands. Raffles' own defence against the Gillespie charges, from which the Dutch historians have mostly derived their material, seem to me to be thoroughly convincing so far as his personal motives were concerned.

23 Gelpke, J. H. F. Sollewijn, De Landerijen onder het Engelsche Tusschenbestuur Verkocht en het Verbod van Heerendiensten aldaar, (1889), pp. 7-8.

24 Muntinghe to Raffles, March 20, [1814], Enclosure No. 20, Gillespie Charges, 35. Some documents relating to the sale of lands under Raffles were published in Anon., Official and Secret Papers Relating to the Sale of Lands and Other Subjects During the British Administration of Java. But all of these have been extracted from the volume of Gillespie Charges. 
sale of Coffee, Spices, or other articles, which were found in the Stores of the former Government.

None of these different methods passed unnoticed, but none of them were found to be practicable or available. - To purchase in the market required cash, which was wanted, and was moreover liable to fraud and imposition. - The drawing of Bills on Bengal was a moral impossibility, under the existing orders of the Supreme Government, and so was the establishment of a Bank; an adequate Sale of Coffee or other valuable articles of trade was also impracticable, not only because the Prize Agents were in the possession of all the valuable produce found in the Stores of the former Government, but because many of those articles were literally unsaleable at the time. The only effectual means, therefore, which could be devised, was a partial sale of Lands.

Raffles saw five main advantages which would result from a withdrawal of the paper currency by means of a sale of lands. These were: ${ }^{25}$

1. That Government will be thereby enabled to sell the Farms and other Revenues for Silver only, and consequently, should a free exportation of Specie be eventually admitted, one part of it at least will be ensured for the demand of the Island. ${ }^{26}$ 2. That the support of the credit Paper circulating in the market, which has evidently been an object of the Governor General in his Proclamation of the 11th September 1811, will be thus secured - an effect which could never take place while there existed so large a quantity of circulating medium, which could not be appropriated to the mercantile concerns of individuals, or to the payment of the most important expences of Government.

3. That a Sale of Lands to the extent required may be readily made in the Batavia Regencies, and in the Environs of the Towns of Samarang and Sourabaya, where, according to the opinion of the Commission appointed to examine the tenure of landed property in Java, such [a] Sale will be not only safe, but moreover beneficial to the future interests and situation of the Colony in general.

4. That the supply of cash thus circulating, and to be brought into the Public Treasury, will, with the aid of Treasury Notes occasionally, as the state of the market may require, enable

Raffles' Minute of November 4, 1812, Java Public Consultations, November 4, 1812. Gillespie Charßes, 82; and Gelpke, J. H. F. Sollewijn, op. cit., pp. $2-3$.

26 See Java Government Gazette, December 12, 1812. 
Government to conduct its expences on the Island without granting any further Bills on Bengal; an object which they are naturally most anxious to effect, in conformity with the sentiments expressed by the Supreme Government in the letter now recorded - and

5. That the Sale of Lands is in strict accordance with the principle of relieving the necessities of this Colony by its own resources, while the Batavia Credit Paper is still retained by Government, in pledge for any future or further disposal of it which the Superior Authorities may direct.

The Government's decision to dispose of lands was made public in the Java Government Gazette three days after the Council meeting, ${ }^{27}$ and the following Committees were appointed to survey the lands in the Batavian Regencies, Krawang, Semarang and Surabaya, and to arrange them into suitable lots for sale.

For the Batavian Regencies and Krawang:

Thomas McQuoid, Resident of Buitenzorg,

P. H. van Lawick van Pabst, member of the Mackenzie

Commission,

William Offers, Resident of Krawang.

For the lands in the environs of Semarang:

R. C. Garnham, Resident of Semarang,

F. von Winckelmann, Inspector of Forests,

J. Knops, member of the Mackenzie Commission.

For the lands in the environs of Surabaya:

A. Adams, Resident of Surabaya,

F. J. Rothenbühler, member of the Mackenzie Commission,

P. A. Goldbach.

The Commissioners were instructed to estimate the extent of lands necessary to raise $200,000 \mathrm{Sp}$. drs. in the Batavian Regencies and Krawang, and to arrange lots of land for disposal at Semarang and Surabaya for similar amounts, making a total of $400,000 \mathrm{Sp}$. drs. ${ }^{2 \mathrm{~S}}$ They were told to parcel out the lands "into such portions and allotments, as appear... most likely to ensure an advantageous sale, and to meet the general wishes and interests of the pur-

27 Ibid., November 7, 1812.

28 The instructions are not clear as to the amounts to be sold in the Semarang and Surabaya environs. In his instructions to the Commissioners at Surabaya, (Gillespie Charges, Appendix O, pp. 224-5; Gelpke, J. H. F. Sollewijn, op. cit., pp. 9-10) Raffles referred to a sum of 150,000 Sp. drs. But see Gillespie Charges, Appendix G, 203. 
chasers". ${ }^{28}$ The lands were to be sold by auction at Batavia, Semarang and Surabaya on January 1, 1813, on the following conditions: ${ }^{30}$

First - The Payment to be made in Silver or Batavia Credit Paper, at the option of the purchasers, the Credit Paper being calculated at $6^{1} / 2 \mathrm{Rix}$ Dollars paper for one Spanish Dollar Silver, and this Payment may be made by the purchaser either at Batavia or on the spot at his convenience.

Secondly - The purchase money is to be paid as follows: One half on the transfer of the Land.

One half on the 1st March, 1813.

Thirdly - All feudal services to the Government, and all forced deliveries at inadequate rates are abolished on the Lands now sold, and in lieu thereof an annual quit-rent of one half per cent is to be paid to Government on the amount of the original purchase. The proprietors, however, will be bound to keep in good repair, the Public Roads and Bridges passing through the Lands, and to furnish such assistance at equitable rates as may be required for Public transport.

Fourthly - No feudal services are to be exacted on these Lands from the persons residing thereon, nor are any payments or revenues to be raised from the people except such as are derived from the produce and culture of the soil, or from the rent of Houses and Buildings, and these Revenues are to be such as are consistent with law, and with the established usage of the country.

Fifthly - The Bazars, Toll Gates, and Capitation Tax, or other taxes now existing on these Lands, are to remain exclusively in the hands of Government - and the Lands now sold, as well as others which have already been sold, are to be held subject to the general Laws and colonial Regulations of Government.

After the sales a Board was to be established at Semarang and Surabaya on the principle of the former Heemraden at Batavia, to regulate the water-courses, the irrigation of padi fields, and other matters concerning the purchasers. Restrictions were placed on Chinese proprietorship, ${ }^{31}$ but the Government declared its willingness

29 Gillespie Charges, Appendix O, 224.

30 Java Government Gazette, November 7, 1812. Gelpke, J. H. F. Sollewijn, op. cit., pp. 5-6; Norman, H. D. Levyssohn, op. cit., pp. 293-4; Gillespie Charges, Enclosure No. 20, pp. 28-9.

31 Instructions to the Commissioners for the sale of lands, November 11, 1812, Gillespie Chardes, Appendix O, 224. Raffles stated that he had made reservations in regard to the Chinese because of "the general recommendation 
to consider private offers for lands before the actual auctions took place.

The Lands Sold.

\section{(a) The Batavian Regencies and Krawang.}

The three Commissioners for the sale of lands in the Batavian Regencies had soon carved out some fine estates, many of them including the coffee plantations which ran along the Hills of Buitenzorg. Their original instructions had directed their attention to the uncultivated lands, ${ }^{32}$ but the coffee gardens were included in the lots in order to establish a clear north-south boundary between the private and the Government lands. ${ }^{33}$ The lots in the Batavian Regencies and Krawang put up for sale are listed on pages $81-2$. $^{34}$

The work of subdividing the lots caused a delay in the auctions. The date of the sale was first postponed from January 1, 1813, till January 15, and then again until January 25. The sales at Semarang did not take place until February 10, while those at Surabaya were not held until five days later. In the meantime, would-be proprietors endeavoured to secure lots by private offers to the Government, or by attempting to bribe the Commissioners. ${ }^{37}$ The first private offer came from a Dutch merchant J. B. Zimmer, who wished to purchase Lots 1 and 2 in the Krawang districts, and Lot 1 in Bandung, for a total of $160,000 \mathrm{Sp}$. drs. paper. This offer was finally accepted by the Government after Lawick van Pabst, Offers and McQuoid reported that it was higher than the price likely to be raised at a public auction. ${ }^{38}$ Zimmer was, however, refused his requests for a

of persons, whose local experience and knowledge entitle them to consideration....", Gelpke, J. H. F., Sollewijn, op. cit. 4. Raffles was undoubtedly referring to the recommendations made by the Dutch members of the Mackenzie Commission, pp. 40; 58 above.

32 Gillespie Charges, Appendix G, pp. 203; 205.

33 Ibid., pp. 31-2.

3. I have extracted the following lists from Java Public Consultations, January 26, 1813. They are fuller than those given by Gelpke, J. H. F. Sollewijn, op. cit., pp. 24-5. A similar list of the Krawang lands is printed in "Stukken betreffende den Landverkoop onder het Engelsche Tusschenbestuur", $T$ ijdschrift voor Nijverheid en Landbouw in Nederlandsch-Indië, (1884), Vol. XXVIII, pp. 181-208.

37 McQuoid reported to Raffles on January 13, 1813, (Java Public Consultations, January 15, 1813) that a Dutchman named Lintels had offered him a diamond pin and breast pin if he helped in negociating a private sale.

38 Java Public Consultations, January 5, 1813. 


\begin{tabular}{|c|c|c|c|c|c|c|c|c|c|}
\hline 范 & 1 & : స్త్స & $\underset{-i}{\tilde{I}}$ & స్త్రే & 惫 & 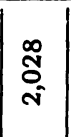 & 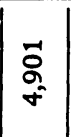 & 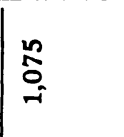 & 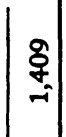 \\
\hline 弯 & 1 & 品 & 疍 & 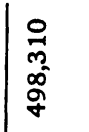 & 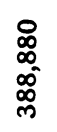 & $\mid$ & 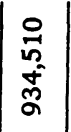 & 兽 & $\begin{array}{l}0 \\
0 \\
0 \\
0 \\
-1 \\
\end{array}$ \\
\hline 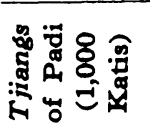 & ठ্. & : & ఖ్లి & 总 & : & స్ఞ & $\begin{array}{c}\overrightarrow{0} \\
\dot{0} \\
m \\
m\end{array}$ & $\stackrel{ొ}{0}$ & 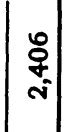 \\
\hline ठ̊. & 1 & in & N & 启 & 1 & 1 & 1 & 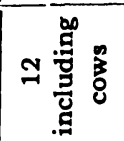 & $\curvearrowright$ \\
\hline 密 & $\approx$ & \pm & $\stackrel{\infty}{\sim}$ & it & $\stackrel{\text { N }}{\text { s. }}$ & $\ddot{8}$ & త్తి & i & $\mid \begin{array}{l}\mathbf{\infty} \\
-\rightarrow=1\end{array}$ \\
\hline 岁 $\frac{\delta}{\sigma}$ & $\stackrel{ \pm}{*}$ & $\aleph_{\Omega}^{\infty}$ & ర్థ & $\stackrel{\infty}{\stackrel{\infty}{~}}$ & $\stackrel{\square}{~}$ & 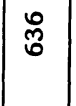 & $\underset{-i}{g}$ & $\vec{\sim}$ & 志 \\
\hline 要 & 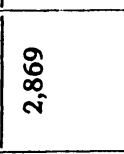 & $\begin{array}{l}F \\
\dot{q} \\
\dot{+}\end{array}$ & 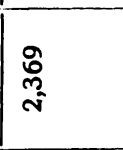 & : & $\stackrel{\text { }}{\text { : }}$ & \begin{tabular}{l}
$\stackrel{8}{g}$ \\
\hdashline
\end{tabular} & $\begin{array}{c}0 \\
0 \\
\text { in } \\
\text { in }\end{array}$ & 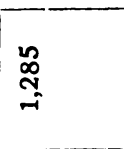 & $\left|\begin{array}{l}\hat{0} \\
0 \\
\dot{y}\end{array}\right|$ \\
\hline 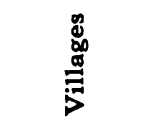 & ஜ & 8 & \& & జี & $\$$ & $\Phi$ & \pm & $\stackrel{i}{i}$ & in \\
\hline 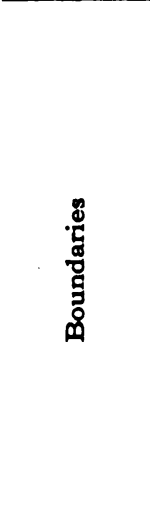 & 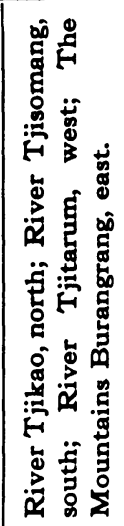 & 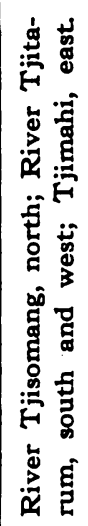 & 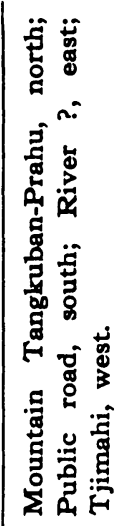 & 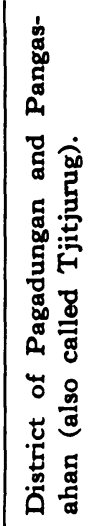 & 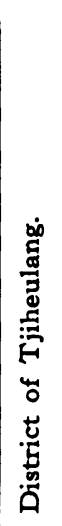 & 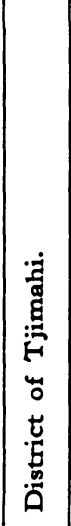 & 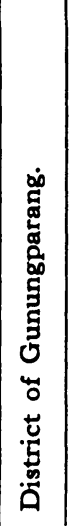 & 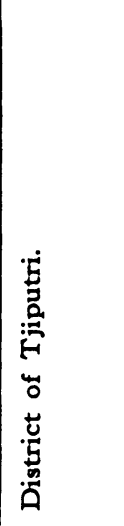 & 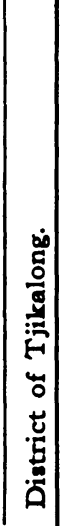 \\
\hline$\vdots$ & $\begin{array}{l}\overrightarrow{1} \\
\dot{z}\end{array}$ & $\begin{array}{l} \\
\dot{\alpha}\end{array}$ & $\mid \begin{array}{l}m \\
\dot{0}\end{array}$ & $\mid \begin{array}{l}+ \\
\dot{\delta} \\
\dot{z}\end{array}$ & $\begin{array}{l}n \\
0 \\
\dot{z}\end{array}$ & $\left|\begin{array}{l|}0 \\
\dot{0} \\
z\end{array}\right|$ & $\left|\begin{array}{l}\hat{0} \\
\dot{z}\end{array}\right|$ & \begin{tabular}{|l|}
$\infty$ \\
$\dot{0}$ \\
$\dot{z}$
\end{tabular} & $\left|\begin{array}{l}a \\
\dot{\alpha}\end{array}\right|$ \\
\hline
\end{tabular}




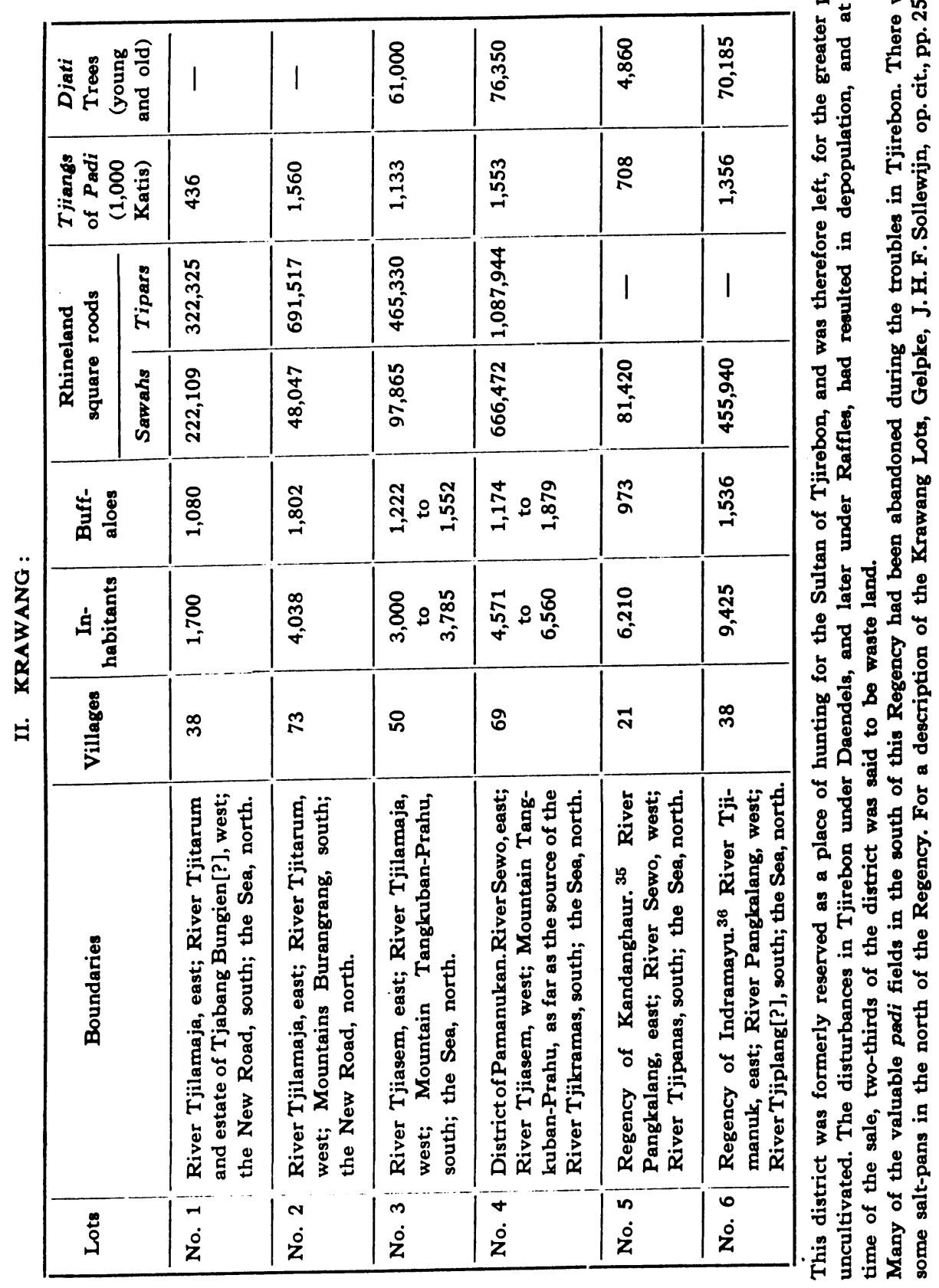


free disposal of the produce of the lands, and the profits from the bazaars, and the opium farm on his estate. ${ }^{3 \theta}$

On January 22, the Government also accepted De Wilde's offer of 40,000 Rix drs. for Lot 3 in Bandung, ${ }^{40}$ and that of Muntinghe for Lot 4 in Krawang (Pamanukan) for 30,000 Sp. drs. paper. ${ }^{41}$ On the same day that the Council agreed to these private disposals, further conditions governing the sales of lands were promulgated. The most important of these stated that the cultivation of coffee on the estates was to be left to the option of the proprietors; that the salt in the lands of Krawang was to be delivered exclusively to a farmer, as in the case of the Salt Farm at Batavia; and that the recently established capitation tax of 24 stivers p.a. on each family in the Batavian and Preanger Regencies in lieu of the salt and other taxes, was to be paid to the Government. ${ }^{42}$

Lot 9 - Tjikalong in Tjianjur - was claimed at this time by the Regent Adipati Wira Tano Datar. He said that he had bought the estate from the Dutch Government for 2,000 Rix drs., but could not produce the deed of sale. In any case, Raffles thought it best to grant him the lot in compensation for any further losses which he might sustain in the sales. ${ }^{43}$

39 Ibid. Zimmer subsequently had to surrender part of these lots because he could not meet the payments.

40 Ibid., January 22, 1813. De Wilde claimed that he had applied for the parcel during Daendels' administration, and had actually been promised it by the Marshal. (De Wilde to Mc Quoid, March 4, 1814, Gillespie Charges, Appendix $Y, 239$.) De Haan rightly questioned this, because it would have boen quite contrary to Daendels' policy. (Priangan, I, "Personalia", 287.) De Wilde repeated his efforts to secure the lot during the early months of the British administration (Ibid., 288), and in October 1812, forwarded a fresh application for the land to the Government. (Cited Ibid., 288). This application was forwarded by Raffles to the Mackenzie Commission for consideration. Mackenzie referred to it in a letter to Lawick van Pabst on October 15, 1812: "I enclose [a] copy of Mr. De Wilde's application to Government for some lands in the District of Bandong, as he is anxious to have it decided soon....", "Letter Book [of the] Commission", op. cit., Letter No. 18. When the sales were announced in November, De Wilde sent in a fresh application for the lands. De Haan, F., Priangan, I, "Personalia", pp. 288-9.

41 Java Public Consultations, January 22, 1813. Muntinghe's offer was made in a letter to Raffles dated January 15, Gillespie Charges, Appendix V, 235. He subsequently sold the lot to J. Shrapnell and Skelton, Ibid., Appendix G, 207. See Gelpke, J. H. F. Sollewijn, op. cit., 27; Norman, H. D. Levyssohn, op. cit., 295.

42 Java Public Consultations, January 22, 1813; Gelpke, J. H. F. Sollewijn, op. cit., pp. $23-4$.

43 Mc Quoid to Assey, December 22, 1812, Java Public Consultations, January 
The public auction for the lands in the Batavian and Preanger Regencies was held at Batavia on January 25, 1813, in the presence of Gillespie, Raffles, Muntinghe, Cranssen and Hope. Bidding was apparently spirited, but the size of the lots prevented any but the "capitalists" (as Raffles called them) ${ }^{44}$ from participating. Before the sale, Engelhard had asked Muntinghe to join him in the purchase of some lands, but Muntinghe was not attracted by the offer..$^{45}$ Engelhard therefore approached Raffles. The latter was forced, so he claimed later, ${ }^{46}$ to accept the proposal because a refusal might have destroyed confidence in the sales. But Raffles' participation in the sale was kept secret, so that the only confidence it could have created was in Engelhard's own mind. It was a foolish action for Raffles to have bought lands, not only because it gave the critics of his administration something concrete to lay against him, but also because it was wholly outside the traditions of British administration in India. His own justification, which has some reason in it to commend it, was that a ruling Governor of Java actually possessing lands was nothing unusual. ${ }^{47}$ At the same time, this only partly excuses an action which was foolish in the extreme, and which eventually was one of the reasons for his removal from Java. ${ }^{48}$

Raffles, Engelhard, De Wilde and McQuoid purchased between them Lots 4, 5, 6 and 7 (Tjitjurug, Tjiheulang, Tjimahi and Gunungparang) of the Bandung-Tjianjur lands for 58,000 Sp. drs. ${ }^{49}$ The total number of people on the estates was nearly 14,000 , and the annual produce amounted to more than 10,000 pikuls of

22, 1813; Gillespie Charges, Appendix Z, 240; Gelpke, J. H. F. Sollewijn, op. cit., 28.

44 Raffles' Minute of February 18, 1814, Gillespie Charges, Appendix G, 207. See also pp. 93-5, Ibid.

45 Muntinghe to Raffles, March 20, [1814], Enclosure 20, Gillespie Charges, 32.

40 Ibid., pp. 7; 131; 209.

47 Ibid., 98. In a Minute of February 28, 1814, (Ibid., Appendix G, 209) Raffles wrote: The lands bought "were a convenient acquisition to the Governor, in as much as they would afford European Vegetables, and enable him to establish a breed of Cattle, and obtain the convenience attached to a Farm, of which the Government-house at Buitenzorg had been deprived by the sale of the Lands in its immediate neighbourhood by Marshal Daendels".

48 Board's Drafts of Secret Letters to India, Vol. 5, No. 97, January 3, 1815.

49 Gillespie Charges, Appendix OO, pp. 262-5; De Haan, F., Prianßan, I, "Personalia", 289. 
coffee,,$^{50}$ and 80,000 pikuls of rice. ${ }^{51}$ It was a bargain. Raffles owned one-half of the total land, ${ }^{52}$ and McQuoid, Engelhard and De Wilde shared one-sixth each. ${ }^{53}$ The other lots in the Batavian and Preanger Regencies were sold as follows:

Bandung and Tjianjur

Lot 2. not sold.

Lot 8. sold to A. Michiels for 13,700 Sp. drs.

\section{Krawang}

Lot 3. sold to J. Shrapnell for 35,000 Sp. drs.

Lot 5. sold to Muntinghe for $31,000 \mathrm{Sp}$. drs.

Lot 6. sold to Muntinghe for $43,000 \mathrm{Sp}$. drs. ${ }^{54}$

There were thus only eight participants in the actual sale, two of them members of the Government, and one a Commissioner for the sale of lands. No wonder suspicions were aroused in Java about the partisan nature of the sales! These suspicions were doubtless fanned by the jealousy of those who could not raise large enough sums to compete with the wealthy purchasers. Raffles claimed that he had disposed of the lands in large parcels in order to attract such "capitalists" because they were the only ones who could have afforded to make the necessary investments to improve their estates.

50 Of 128 lbs. per pikul. The produce of 10,000 pikuls of coffee on Raffles' estate was a very high proportion of the total produce of the estates in Bandung and Tjianjur actually sold. The other lots produced only a total of 3,700 pikuls of coffee. Gillespie Charges, Appendix P, 227. Compare Raffles Ibid., Appendix G, 210: "The Lands consist of three lots almost entirely waste, and a fourth in a state of tolerable cultivation, and the object was to unite them, in order to render the Districts which were uncultivated assist in the transport of the produce of that which was cultivated". Some capital was apparently invested for the improvement of cultivation during 1813. (Loc. cit.)

51125 lbs. per pikul.

52 Raffles found some difficulty in raising the $27,000 \mathrm{Sp}$. drs. as his part of the purchase money, and had been forced to borrow the sum from Robinson. When he learnt of the charges which had been preferred against him by Gillespie for participating in the sale, he quickly got rid of his share to Engelhard and De Wilde at the original price. The new division of ownership of the estate was thus: De Wilde 5/12; Engelhard 5/12; and McQuoid 1/6. On the subsequent history of De Wilde and his estate, see Ottow, S. J., op. cit., pp. 169 et seq.; De Haan, F., Priangan, I, "Personalia", pp. 290 et seq.

53 Gillespie Charges, Appendix OO, pp. 262-5; Appendix T, 231.

54 Ibid., Appendix OO, pp. 262-5; Gelpke, J. H. F. Sollewijn, op. cit., 29. 
"Small Estates... would not have sold", he informed the Supreme authorities when the sales came under attack, ${ }^{55}$ "because it could not answer the purpose of wealthy men and speculators to sink their Money unless on a chance of considerable profit eventually - and thus, although there were several Bidders for each Lot separately, they fell off into the hands of a few large Capitalists, who could afford to bid highest in order to obtain a connected and extensive property.

Most of the Estates in the Western Division are of this nature, and however desirable it would have been to have sold the Lands in smaller Farms, a sale under such circumstances could not have been effected - but the Lots now sold are adjoining to each other, and it may be probably expected in time that as civilization extends, and the scope for speculation without adequate capital becomes lessened by the difficulty of borrowing Funds, many landed Estates will be separated, and Colonial landed property will become more generally divided".

\section{(b) Semarang.}

The lots offered for sale at Semarang and Surabaya were smaller because of their proximity to the towns. ${ }^{56}$ The Semarang lands are listed opposite. ${ }^{57} \mathrm{~A}$ full list of the purchasers, who included the Commissioners Knops (Gumulak) and Lawick van Pabst (Lots 1 and 2), has already been published. A few of the lots were not sold, and Lot 8 which Middelkoop had bought, was subsequently repurchased by the Government. ${ }^{58}$ The Semarang lands brought a total of 159,676 Sp. drs. ${ }^{59}$

57 I have extracted the particulars from a much fuller list in Java Public Consultations, January 26, 1813. The list has been printed, Anon., "Rapport omtrent de Partikuliere Landerijen beoosten de rivier Tjimanoek", Tijdschrift voor Nijverheid on Landbouw in Nederlandsch-Indië, (1878), Vol. XXII, between Bijlage Ia and Bijlage $\mathrm{K}$, but inaccurately. The list of purchasers of the Semarang lands is on p. 244.

Gillespie Charges, Appendix M, 222.

Ibid., Appendix MM, 261; Norman, H. D. Levyssohn, op. cit., 295. A figure of 163,160 Sp. drs. is given in Java Public Consultations, February 26, 1813, but this includes the amount Middelkoop paid for Lot 8, which was subsequently bought back from him. The total proceeds from the sale of lands in Batavia, Semarang and Surabaya was $455,443 \mathrm{Sp}$. drs., being the equivalent of 2,960,381 Rix drs. (Gillespie Charges, Appendix MM, 261). After deducting the money refunded to $Z$ immer, who could not meet the terms of his private offer, and allowing for other minor adjustments, the total amount which the Government netted from the sales was only 375,443 Sp. drs. (Ibid., 208). 


\begin{tabular}{|c|c|c|c|c|c|c|c|}
\hline Lots & Villages & Huts & $\begin{array}{c}\text { Men } \\
\text { able } \\
\text { to } \\
\text { work }\end{array}$ & $\begin{array}{c}\text { Chiefs } \\
\text { of } \\
\text { Villages }\end{array}$ & $\begin{array}{l}\text { Reli- } \\
\text { gious } \\
\text { Of- } \\
\text { ficials }\end{array}$ & $\begin{array}{c}\text { Buffa- } \\
\text { loes }\end{array}$ & Horses \\
\hline $\begin{array}{l}\text { District } \\
\text { of } \\
\text { Gumulak }\end{array}$ & 29 & 1,057 & 883 & 64 & 44 & 1,344 & 44 \\
\hline $\begin{array}{l}\text { District } \\
\text { of } \\
\text { Torbaya }\end{array}$ & $\begin{array}{c}3+53 \\
\text { kampongs }\end{array}$ & 780 & 567 & 14 & 25 & 34 & 8 \\
\hline $\begin{array}{l}\text { District } \\
\text { of } \\
\text { Kaligawe }\end{array}$ & $\begin{array}{c}15+72 \\
\text { kampongs }\end{array}$ & 1,465 & 1,303 & 33 & 13 & 327 & 17 \\
\hline Lot 1 & $\begin{array}{c}11+7 \\
\text { kampongs }\end{array}$ & 636 & 517 & 29 & 13 & 225 & 2 \\
\hline Lot 2 & 19 & 480 & 389 & 38 & 19 & 182 & - \\
\hline Lot 3 & 12 & 402 & 315 & 24 & 12 & 217 & - \\
\hline Lot 4 & 13 & 241 & 173 & 26 & 7 & 198 & - \\
\hline Lot 5 & $\begin{array}{c}20+8 \\
\text { kampongs }\end{array}$ & 1,071 & 959 & 30 & 12 & 199 & 1 \\
\hline Lot 6 & 18 & 444 & 391 & 36 & 18 & 203 & 9 \\
\hline Lot 7 & $\begin{array}{c}4+14 \\
\text { kampongs }\end{array}$ & 435 & 378 & 18 & 7 & 90 & 9 \\
\hline Lot 8 & $\begin{array}{c}8+1 \\
\text { kampongs }\end{array}$ & 217 & 188 & 14 & 3 & 141 & 1 \\
\hline Lot 9 & 6 & 159 & 126 & 12 & 4 & 145 & 1 \\
\hline Lot 10 & $\begin{array}{c}14+9 \\
\text { kampongs }\end{array}$ & 472 & 403 & 29 & 10 & 172 & - \\
\hline Lot 11 & 7 & 93 & 74 & 9 & 3 & 21 & 一 \\
\hline Lot 12 & $\begin{array}{c}4+1 \\
\text { kampongs }\end{array}$ & 223 & 198 & 7 & 3 & 36 & 12 \\
\hline Lot 13 & $\begin{array}{c}3+12 \\
\text { kampongs }\end{array}$ & 432 & 359 & 10 & 21 & 13 & 3 \\
\hline
\end{tabular}




\section{(c) Surabaya.}

Few lands were sold at Surabaya, ${ }^{60}$ and the competition was not keen. Reporting on the sale the day after the auction, Adams informed Raffles that there was "not the least competition, nor was there any bidder... except the inhabitants of Surabaya". ${ }^{61}$ The total amount raised by the sales there was only 78,912 Sp. drs. ${ }^{62}$

\section{The Financial Results of the Sale. ${ }^{63}$}

The object of the sale of lands had been the withdrawal of the depreciated paper currency from circulation, and this Raffles partly achieved ${ }^{64}$ But unwisely, he immediately issued another quantity of paper on the guarantee of the Government, ${ }^{85}$ and the result was, of course, a sharp depreciation. Actually Raffles had few alternatives at the beginning of 1813 but the reissue of a paper currency. The amount of specie in circulation had rapidly diminished during the course of 1812, and fresh supplies were wanting because the balance of trade remained unfavourable. Raffles had thought that payments for the lands would have been made in silver as well as in paper, but only paper appears to have been offered. Indeed, by recognizing Minto's original rates of $61 / 2 \mathrm{Rix}$ drs. paper to $1 \mathrm{Sp}$. dr. silver, little else could really have been expected. It has been argued in this connection that Raffles was unwise in admitting the depreciated paper money at the sales. ${ }^{66} \mathrm{He}$ should instead have accepted only specie. Raffles asserted in reply to this criticism, with much justification, that a sale conducted for silver only would have been fruitless, ${ }^{67}$ since it was the very lack of specie which had caused the depreciation in the value of paper money. He claimed, moreover, that he could not have established new rates for the paper because he was morally bound to respect Minto's earlier proclamation. ${ }^{88}$

60 For further information and details about the Surabaya lands, Java Public Consultations, January 26, 1813.

01 Adams to Assey, February 16, 1813, Ibid. A list of purchasers, who included Rothenbühler, can be found in Tijdschrift voor Nijverheid on Landbourw in N.I., Vol. XXII, pp. 245-7.

02 Java Public Consultations, February 26, 1813; Gillespie Charges, Appendix MM, 261; Norman, H. D. Levyssohn, op. cit., 295.

(63 Footnote 59, p. 86 for the total sum raised by the sale.

64 Minute by Raffles, February 18, 1814, Gillespie Charges, Appendix G, 208.

65 Minute by Raffles, March 31, 1813, Java Public Consultations, March 31, 1813. Treasury notes to the value of $250,000 \mathrm{Sp}$. drs. were first issued.

68 Gillespie Charges, 72.

67 Ibid., 91.

08 Loc. cit. Gillespie charged Raffles with the withholding of paper during the sales in order to prevent competition. (At the time of the sale a total of 
The whole trouble was, of course, that a sale of lands in those circumstances was no solution to the financial problems which faced the Java Treasury at the end of 1812. Daendels' own experience should have made that clear to Raffles. But while this criticism is valid, it is difficult to suggest any satisfactory alternative to a sale of lands. Even Minto, who was not altogether happy about the sale, was forced to admit that it had been "an able expedient in a case of great emergency", ${ }^{89}$ and both Edmonstone and Seton, the members of the Bengal Council, agreed. ${ }^{70}$

\section{The Question of Forced Services on the Private Estates.}

It is beyond the scope of this study to investigate in any detail the actual practice of the proprietors in demanding forced services from the people once they were in control of the estates. Sollewijn Gelpke in his little-known book De Landerijen onder het Engelsche Tusschenbestuur Verkocht en het Verbod van Heerendiensten aldaar (1889) has shown clearly enough that whatever Raffles' views on the question of forced services were, he was powerless to prevent the proprietors from demanding them on their estates. ${ }^{71}$ For the

3 millions of Rix drs. was in the Government Treasury, and another 2 millions in the hands of the Vendue Department, Orphan Chamber and other institutions.) Raffles' counter to this was that he wished to withdraw paper from circulation, and that to have issued it in large amounts would have been rather foolish. (Ibid., 152). There is something to be said both for Gillespie and Raffles on this question. The shortage of paper at the time of the sale would undoubtedly have had the effect of reducing competition; but at the same time to have flooded the market with paper would have produced few beneficial results.

69 Minto to Raffles, November [22], 1813, Lady Raffles, Memoir, 196. Minto at first approved the sales (Minto to Raffles, June 24, 1813, Ibid., 189) probably because he thought it was an attempt to follow his instructions. But he was surprised to learn of the extensive sales later, and politely told Raffles so.

70 Edmonstone in a Minute of June 18, 1814, (Java, Vol. 63) admitted the financial difficulties which confronted Raffles, but was not prepared to commit himself on the wisdom of the measure. He expressed, however, complete faith in Raffles' personal motives for the sales. Seton in a Minute of the same date, (Ibid.) stated that given the pressing financial situation in Java, the sale of lands was the best local measure that could have been adopted, except, perhaps, the leasing of the lands.

71 Mackenzie had advised Raffles in October 1812, after he had inspected the lands around Semarang and Surabaya, to establish strict regulations regarding the rights of the people on the estates. "I conceive", he wrote, "it would be an object of importance 86 humane consideration with Government, in the event of selling these lands, to devise such a system of regulation 86 
moment, I wish to examine briefly the protests on this controversial subject addressed by the Commissioners for the sale of lands to Raffles before the auctions actually took place, because those protests reflected the views of the Dutch members of the Mackenzie Commission, and generally repeated arguments which had been advanced in the Commission's reports. They also reflected clearly the predominant attitude of the European proprietor class in Java at the time.

As early as November 25, 1812, the Surabaya Commissioners for the sale of lands had written to Raffles objecting to the prohibition on the exaction of services stated in the conditions of sale.

[B]e it permitted us to observe, that it will be impossible to cultivate the lands to so much advantage as they might be capable of yielding, without admitting servitude on equitable terms. No Javanese will do more work than his own utmost necessity requires. If two acres of land supply his wants, he will certainly not cultivate a third, and it frequently happens that, when his crop is very abundant and he has gathered a supposed sufficiency for his use, he leaves the surplus on the field, being too lazy to bring it home. We think therefore, that some modification is highly desirable.

... If the landowner... is not permitted to levy ... [the Wang Grabag or Wang Tjatjah or Capitation] Tax, he loses the profit of the ground which he bought and paid for, because the whole extent of the Dessas, where the Javanese has his house and trees, is included in the number of acres he purchased. ${ }^{72}$

If, however, Raffles viewed the matter in another light, and thought that the tax should be levied for the benefit of the Government, then the Commissioners believed it should be collected by the proprietors for the Government "without the interference of native chiefs whose influence upon the Javanese proprietor of the land,

reservation, as may tend to secure the comfort \&s protection of the Families now resident on these lands, thus coming into the possession of private Individuals;... [and] the period or term of warning of removal, of the compensation \&5 remuneration of property in houses, trees, or other improvements of the ground occupied by families should be regulated". Mackenzie to Assey, October 15, 1812, "Letter Book [of the] Commission", op. cit., Letter No. 17.

i2 Adams, Rothenbühler and Goldbach to Raffles, November 25, 1812, Java Public Consultations, January 26, 1813; Gelpke, J. H. F. Sollewijn, op. cit., 11. 
we consider as highly prejudicial". ${ }^{73}$ The Commissioners forwarded a set of regulations incorporating these ideas, ${ }^{74}$ and asked Raffles to approve them. The main point of these regulations was that the people on the private estates were to be subject, under specified conditions, to the landowners, who were to be able to divide the lands among them as they thought fit. The European proprietors were also to have the rights "to exact private services from their male tenants". ${ }^{75}$

It was not only the Surabaya Commissioners who complained about the restrictions which were to apply to the exaction of feudal services. Garnham had asked Raffles at the end of November to remove these restrictions, and grant the proprietors the right of collection of the capitation tax. ${ }^{76}$ Raffles replied that the advertised conditions governing the sales would have to be considered as final. ${ }^{77}$ But when Lawick van Pabst and Offers both attempted to persuade him that if the proprietors were not allowed to exact feudal services, any improvement in cultivation would be impossible, ${ }^{78}$ Raffles felt it necessary to issue more defined regulations. The most important of these gave the proprietors the option of continuing the cultivation of coffee on their estates. ${ }^{79}$ McQuoid in a separate report expressed the opinion, ${ }^{80}$ which Raffles probably shared, that it was "hardly in the power of Government, publicly to convey to, or sanction in Landholders the exaction of feudal services from their tenants." $\mathrm{He}$ told Raffles that the proprietors would not be "tyrannical or oppressive" since the people were not transferred with the lands, and would flee if subjected to ill-treatment. In this pleasing fiction, Raffles, like the ostrich, buried his head. Writing in February 1814 on the conditions which had been established for the sales, he stated: ${ }^{81}$

73 Loc. cit.

74 Gelpke, J. H. F. Sollewijn, op. cit., pp. $12-3$.

75 Ibid., 13.

76 Garnham to Assey, November 28, 1812, Java Public Consultations, January 26, 1813; Gelpke, J. H. F. Sollewijn, op. cit., 11.

77 Raffles' reply was dated December 4, 1812, Java Public Consultations, January 26, 1813.

78 Gelpke, J. H. F. Sollewijn, op. cit., 17.

78 Ibid., pp. $23-4$.

80 McQuoid's report is in Java Public Consultations, January 26, 1813; and Gelpke, J. H. F. Sollewijn, op. cit., pp. 15-23. Italics mine.

81 Minute by Raffles, February 18, 1814, Gillespie Charges, Appendix G, 204. 
From these Conditions it will be evident that every practicable attention was given to the interests and welfare of the population - they were expressly retained under the protection of the Government, and it should not be forgotten that in point of fact they have been emancipated. Their feudal service is abolished, the forced deliveries and vexatious taxes... have since been altogether done away, and Government have only given up in these Sales that Revenue from the people, or in other words, that proportion of the crops, to which, as Lords of the soil, they had an indisputable claim.

It was on the latter principle - the Government's sovereign rights to the soil - that Raffles came to justify his sale of lands. It was this principle, too, which provided the theoretical basis for the land rent system, which was introduced into the North Eastern districts of Java in 1813. 


\section{THE EARLY LAND RENT SETTLEMENTS IN THE TRANSFERRED DISTRICTS AND BANTAM 1812-1813}

The enthusiasm which Raffles displayed in the years 1813 and 1814 in introducing a land rent system into Java stemmed immediately from the financial difficulties which confronted the colonial Treasury once the palliative effect of the sale of lands began to wear off. The reisssue of a paper currency in 1813 in the form of Treasury notes with a yearly interest of $6 \%{ }^{1}$ did not prevent their depreciation, and the commercial speculations at Canton, and in the islands brought little relief to a depleted exchequer. But while the grave financial crisis presented the occasion for Raffles' enthusiasm for land reform, we must remember that he was bound to attempt such a reform under the original instructions left by his patron, Lord Minto. We have seen how quickly he established the Mackenzie Commission to investigate the problem, and how anxious he was to have a cut-and-dried programme of reform placed before him. In the meantime, first in Bantam, and later in the Transferred Districts, a land rent system was being developed gradually, and it was to this that Raffles finally turned in 1813 as the means of raising an adequate revenue to cover the costs of his administration.

As has been shown above, Raffles suggested the idea of the Bantam revenue settlement to the Mackenzie Commission as an effective solution to the problem of introducing a system of free trade and cultivation into Java. But the Dutch members of the Commission took little notice of the suggestion, and recommended instead a wholesale disposal of lands, with the establishment of a European proprietor class. It requiried only the partial sales of 1813 to show Raffles that reform did not lie in that direction. More and more he became convinced that the only effective way of raising an internal revenue was by the extension of the Bantam revenue settlement

1 These had also been issued in the previous year, Java Government Gazette, August 1, 1812; and August 8, 1812. 
throughout the island. But in 1812 he was feeling his way, and it was in the middle of that year that he was confronted with the problem of introducing a European administration into the Transferred Districts. It was natural that he turned to the Bantam experiment as a guide.

\section{The Transferred Districts.}

In June 1812, the British forces under Gillespie stormed the kraton of the Sultan of Yogyakarta, Amangku Buwana II, and by a definitive treaty ${ }^{2}$ placed the hereditary prince on the throne. This was the culmination of the old Sultan's refusal to recognize his dependence upon the British Government, and his intrigues with the court of Solo to drive the Europeans from Java. ${ }^{3}$ By article 3 of the treaty signed with Amangku Buwana III, it was agreed that the Sultan would deliver "to the entire management and sovereignty of the British Government his share of the Districts of Cadoe and Pagitan, together with the Districts of Djapan, Djipan and Grobogan, with its Dependencies". By an earlier treaty with the former Sultan ratified in December $1811,{ }^{4}$ the British had restored the provinces ceded to Daendels, except Grobogan, and the harbour of Patjitan. Now the districts were reclaimed in full sovereignty.

In explaining the new treaty to Minto, Raffles stated his intention of introducing "an improved administration of the Revenue" into the Transferred Districts. ${ }^{5} \mathrm{He}$ spoke optimistically of the financial and strategical benefits which would be derived from the acquisitions, especially from the districts of Patjitan and Kedu. "The Cadoe," he wrote, "... is peculiarly important to the European Government from its local situation, approaching nearer to the Northern Coast, than any of the other Provinces of the Native Princes, and forming... an obvious separation of the Western from the Eastern Provinces of the Company. By the acquisition of Cadoe, the central Districts of the Island are also most essentially covered from the eruptions of predatory parties to which they have hitherto been exposed". ${ }^{\circ}$

2 Deventer, M. L. van, N.G., pp. 321-6.

3 Ibid., pp. XIII-XVI; Lady Raffles, Memoir, pp. 125-9; Veth, P. J., Java, II, pp. 299-307; Graaf, H. J. de, op. cit., 376.

4 Deventer, M. L. van, N.G., pp. 314-9.

5 Raffles to Minto, August 6, 1812, "Observations explanatory of the Treaty with the Sultan of Mataram", Java, Vol. 60, Part I.

6 Loc. cit. 
In the districts of Djipang, Djapan and Grobogan, there had been a decrease in the amount of cultivated land due to the harshness of native rule, and Raffles estimated their current revenues at only 57,000 Sp. drs. But he considered the districts valuable because of their djati forests, and also because he thought their revenues could be increased rapidly under a peaceful British administration. ${ }^{7}$

By a similar treaty with the Susuhunan at this time, ${ }^{8}$ his portions of Kedu and Patjitan were also ceded to the British, and the districts of Blora and Wirasaba, formerly granted to the Dutch, were taken possession of. In addition, both the Sultan and the Susuhunan placed the management of the bazaars and tollgates in the hands of the British Government in return for payments of 100,000 and $120,000 \mathrm{Sp}$. drs. per annum respectively. The British were also given the exclusive monopoly of the edible birds'-nests, the sale of opium, and the sole rights to djati in the Principalities.

Shortly after the cessation of hostilities against Yogyakarta, Raffles appointed a Committee under the Civil Commissioners to investigate the revenues of the Transferred Districts, and to establish a regulated system of collection. John Crawfurd, the Resident at Yogyakarta, superintended the main investigations in Patjitan and Kedu, and he was fully occupied in this task until the end of $1812 .{ }^{9}$

\section{Patjitan.}

Crawfurd began investigating the land tenures of Patjitan in July, and by the end of the following month thought that he had solved that particular problem. As in his investigations in the Sultan's domains, ${ }^{10}$ he found that the ground of Patjitan was "the undoubted property of the Sovereign", 11 who disposed of it arbitrarily. "Indeed," he wrote to Raffles, "such slaves to prejudice are the people, and so debased are their minds by the contemplation of despotic powers, that I am convinced it would be no easy matter to render

7 Loc. cit.

8 Deventer, M. L. van, N.G., pp. 327-31.

9 De Haan, F., "Personalia", 527.

11) See pp. 36-9.

11 Crawfurd, J., "Report upon the District of Pachitan", Mack. Coll., (Pr.), Vol. 21, No. 5. This copy of the Report is undated, but another in the Raffles Collection, II, No. 8, carries the date of August 25, 1812. On Patjitan see also "Memorandum on Patjietan", July 14, 1812, by Major D. H. Dalton, Mack. Coll., (Pr.), Vol. 21, No. 6. In A Descriptive Dictionary of the Indian Islands \& Adjacent Countries, (1856), sub "Pachitan", 317, Crawfurd stated that when he visited the district in 1812 it was "but a poor place". 
intelligible to them any other notion of right in the soil". ${ }^{12}$ Although Crawfurd understood that the Bekels were not the initial recipients of the land from the sovereign, and described them as merely "tenant[s]-at-will", ${ }^{13}$ he thought that the Bekels were the most convenient class for the Government to deal with under the new land rent system, because they were familiar with the modes of collection under the native administration.

By the agreement with the Dutch Company for the delivery of pepper and rice, the Sultan and Susuhunan had been forced to forgo the rights of collecting the taxes from Patjitan, and simply demanded those two commodities from the peasants, for eventual delivery as contingents. Crawfurd claimed that this "injudicious system" had impoverished Patjitan "by drawing the industry of the people to a forced cultivation in the success of which they could take no interest, and which was consequently unproductive, thus defeating its own object". In place of the contingents and other payments in kind, he established "a fixed money rent" payable twice a year. He called the Bekels together and explained his intentions to them.

I ... told them that they were now to enter into conditions with the British Government on behalf of themselves, and the Villages under their authority for one year, and that they were in future to be exempt from the payment of contingencies and forced services of all descriptions, to which the British Government was always averse, as knowing them burthensome and vexatious to the people, on payment of a fixed rent in money.

I further informed them that they were at liberty by this agreement to cultivate the little pepper that remained for their own benefit. ${ }^{14}$

According to Crawfurd, the Bekels "willingly acquiesced" in this proposition, and so he established a "trifling" rental, having accepted terms "nearly those proposed by the individuals themselves". He explained to Raffles that he had not made heavy demands because he thought that in this first interference in the details of native administration "it was evidently more wise and politic to leave upon the minds of the people an impression of forebearance and liberality,

12 "Report upon... Pachitan", op. cit.

13 Loc. cit. "[N]ot an individual of them", Crawfurd wrote of the Bekels of Patjitan, "is ever possessed of... influence nor of authority beyond the precincts of one or two villages". See pp. 37; 118-9.

14

Loc. cit. 
than make a trifling increase of Revenue". He advised, however, that after the first yearly settlement had expired, the land rent of Patjitan should be doubled. ${ }^{15}$

Fortunately, the complete figures of Crawfurd's first assessment of Patjitan exist, and from these we can understand the ideas behind his settlement. The lists are too massive to reproduce here, and the following summary of receipts and disbursements must suffice. ${ }^{16}$

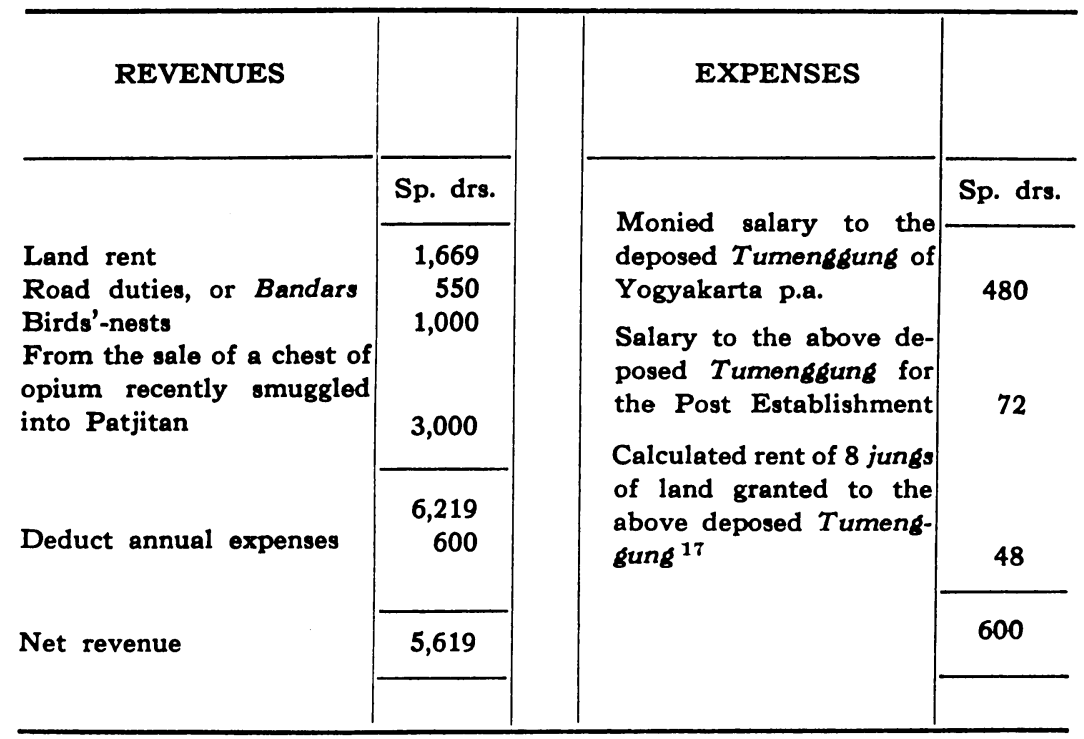

In making his land rent settlement upon the Bekels, Crawfurd was forced to dispose altogether of the services of the Tumengsung who represented Solo, but used the other Tumengsung appointed by the Sultan ${ }^{18}$ for the maintenance of good order in Patjitan. He was, however, lowered to the rank of Demang, and removed from all interference in judicial matters. He was granted a monied salary for his new duties, and to compensate him for his loss of title.

Crawfurd's settlement of Patjitan was made on conditions of lease, and resembled the Indian village settlements. This was the type of settlement which he later came to defend against Raffles'

15 Loc. cit.

16 Bengal Civil Colonial Consultations, January 16, 1813.

17 In his "Report upon... Pachitan", op. cit., Crawfurd gave the figure as 6 jungs.

18 The Tumengsungs of Patjitan occupied similar positions to those in Kedu, Eindresumé, II, 152. 
introduction of the Ryotwari system. ${ }^{19}$ But in the previous April, Crawfurd had found some similarity between the Bekels and the Zamindars in British India, ${ }^{20}$ and during his investigations in Patjitan and Kedu he became more convinced that it was only among the Bekel class that any claims to proprietary rights could be made. "Though with regard to this class of Bekals", he wrote in November $1812,{ }^{21}$ "the occupation of their office be liable to the same instability which belongs to all that relates to the soil, yet their numbers, their want of consequence of removing them, render[s] them less liable to change than their more powerful superiors, and for this reason with many of them there is a faint show of hereditary claim". In making his settlement in Patjitan, therefore, Crawfurd was probably under the impression that he had commenced a Zamindari type of settlement on a small scale. He certainly conveyed this idea to Raffles, for in October the latter informed Minto that the settlements made in Patjitan and the other Transferred Districts had been based "on the principles adopted in Bengal, as far as local circumstances would admit". ${ }^{22}$

The Supreme Government praised the Patjitan settlement, doubtless because of the expectation of large revenues.

\begin{abstract}
"The measures which you have adopted for settling the Revenue of the Districts ceded under the late Treaties with the Native Chiefs appear to us very judicious", Minto informed Raffles early in 1813, "and the assurances which you give us that a considerable Revenue is likely to be realized from those Districts, and that the tranquillity of the Island generally has been secured by your late arrangements, afforded us matter of the highest satisfaction.

We perused with much interest the report on the District of Pajetan submitted to you by the Resident, Mr. Crawford [sic]; and from this specimen of his diligence and zeal, and from the evidence which the report affords of Mr. Crawford's [sic] arrangements, which seem peculiarly to qualify him for
\end{abstract}

14 See Crawfurd, J., A Descriptive Dictionary of the Indian Islands..., sub "Raffles", 364.

201 See p. 37.

21 "Report upon the District of Cadue by Mr. Crawfurd", November 15, 1812, Mack. Coll., (Pr.), Vol. 21, No. 8. There is another copy in "J. Crawfurd, Papers on Java, Cochin China etc., 1811-1823", Add. Mss. 33, 411. Italics mine.

2:2 Raffles to Minto, October 6, 1812, Bengal Civil Colonial Consultations, January 16, 1813. 
such researches, we are persuaded that the labours of that Gentleman will be productive of great advantage to the public service".23

Kedu.

In the meantime, on September 10, 1812, Crawfurd had commenced the introduction of the land rent system into Kedu. On its assumption by the British, Raffles had described Kedu as "without exception the finest Province of the Island", and had estimated its yearly revenue at 150,000 Sp. drs. ${ }^{24}$ Crawfurd's assessment was considerably less, but he agreed about Kedu's agricultural wealth. "Towards the foot of the western hills [where sawah cultivation was practised]", Crawfurd stated in his report, ${ }^{25}$ "the fertility of the soil and the abundant supply of water, are at once so remarkable as to produce the richest scene of cultivation I ever beheld. This part it is which by the Javanese is properly denominated the Cadoe, and it is held by themselves to be by far the richest spot upon the whole island".

Commerce was, however, greatly handicapped in Kedu by the market taxes and toll-gate levies collected both by the agents of the Susuhunan and the Sultan. These taxes were collected by farms, and Crawfurd found that they had all fallen into the hands of the Chinese. He estimated that the nominal taxes were increased by half due to the costs entailed in this mode of collection. He suggested, therefore, that the arbitrary taxes, which eventually had to be borne by the cultivators, should be removed, and a fixed monied land rent substituted.

Crawfurd's object in the Kedu settlement was to create "a permanent interest in the occupation and possession of the soil", ${ }^{20}$ and as in Patjitan he thought that the lands should be leased to the Bekels. ${ }^{27}$ But in Kedu he proceeded more cautiously, and in the first settlement of the land rent granted annual leases to both the

Minto to Raffles, January 23, 1813, Bengal Civil Colonial Consultations, January 23, 1813.

24 "Observations explanatory of the Treaty with the Sultan of Mataram", op. cit.

25 "Report upon... Cadoe....", op. cit. I have taken most of my information about Kedu from this Report. See also, Crawfurd, J., A Descriptive Dictionary of the Indian Islands...., sub "Kâdu", 194.

20 Crawfurd, "Report upon... Cadoe....", op. cit.

27 The claims of the Bekels were stronger in Kedu. Eindresumé, II, 152. 
Bekels and Demangs. Among the Demang class were many Chinese, who had secured possession of their lands by making loans to the Sultan and Susuhunan. Despite their oppressions, Crawfurd felt that it was a "matter of justice and necessity" to respect the Chinese leases. However, he attempted to modify the abuses, and where the leases had expired, or where documentary proof could not be furnished, the lands were removed from their charge, and leased to the Bekels at a "fair rent". Although Crawfurd was forced to grant some leases to the Demangs, he advised Raffles not to extend these leases when they expired.

"[B]y employing the Demang", Crawfurd wrote, ${ }^{28}$ "we only employ an unnecessary native agent in the collection of rents, whose profit or salary is lost to the revenues, while the Bikal and cultivator are both oppressed by it. The Demangs ... take no share in the details of husbandry, and with such precarious tenures cannot be expected to take much interest in the improvement of the lands. Even were they to do so, with their expensive habits and the parade of idle followers which they usually support, they could not be expected to bring to its improvement the same amount of capital as the aggregate of the Bikals under them, who possess habits far more industrious and frugal.

By employing the Bikals only, and this is by far the most important point, we remove the barriers which the prejudice of ages have opposed to the administration of Justice, and which have paralized the minds \& exertions of the Javanese".

He admitted that the rents could be more easily collected by the Demangs. However, he thought that the experience of Patjitan had shown that there were no serious obstacles in the way of collections by the Bekels.

With the assistance of active native agents, Crawfurd made a statistical survey of Kedu. ${ }^{29} \mathrm{He}$ called the Demangs and Bekels together to arrange the basis of the new settlement, and after receiving reports on the former revenue and allowing a reasonable sum for the subsistence of the Demangs, calculated the remainder as the revenue of the Government. With the Bekels the task proved

28 Crawfurd, "Report upon... Cadoe ....", op. cit.

29 This was a vast compendium of information, detailing the sawahs and tegals, the population, number of cattle, number of ploughs, and so on. Unfortunately there is no copy in the India Office Library, although one may exist among the Revenue Letters in the Archives at Djakarta. 
more formidable, because in most cases the Bekels had to be considered in the settlements made with the Demangs. But where the Demangs had been removed, the Bekels were given leases directly, and the rent collected from them. Ultimately, Crawfurd wished to grant the Bekels leases for five, or even ten years, but in the first settlement leases were given for a period of one year only. Because he had been forced in the first instance to take notice of the claims of the Demangs, Crawfurd did not feel happy about the Kedu settlement. "I have not acted upon the System which in theory appeared most perfect", he told Raffles, ${ }^{30}$ "but... was guided in practice chiefly by motives of expedience".

Few details of the first assessment of the land rent of Kedu exist. All we know is that a monied rent amounting to 112,000 Sp. drs. per annum was established, and that the first three halfyearly collections were made without default. ${ }^{31}$ The reasons which Crawfurd gave for establishing a rent in money instead of one in kind are interesting. He yielded, he said, "to the earnest and invariable solicitude of the people to commute the payment in kind into one of money". 32 The only people whom a monied rent would have benefitted, however, were the Chinese, who were able to make advances upon the crops in cash. In this manner they gradually secured a firm hold over the cultivators.

\section{Djapan.}

Lieutenant $\mathbf{R}$. Hart made the first land rent settlement in Djapan and Wirasaba towards the end of 1812. Hart, however, only assessed the padi fields in Djapan (at a rental of 10,346 Sp. drs.), ${ }^{33}$ but when Jourdan arrived there early in the following year to succeed him, an attempt was made to extend the land rent to the other cultures at a lower rate. Jourdan told Raffles that unless this were done, the rent levied on rice only, would prove a discouragement to its cultivation. ${ }^{34}$ After a careful survey of the district, he found that more than 50 jungs of padi fields had

30 Crawfurd, "Report upon... Cadoe....", op. cit. See Sub., 272.

31 Sub., 44.

32 Crawfurd, "Report upon... Cadoe....", op. cit.

33 "Japan and Wirosobo", by Lieutenant H. G. Jourdan, April 28, 1813, Mack. Coll., (Pr.), Vol. 21, No. 10. The rents from the Bandar and opium farms added another $4,000 \mathrm{Sp}$. drs. to the revenue of Djapan.

is Loc. cit. 
escaped Hart's assessment, and so he added another 1,000 Sp. drs. to the total land rent. ${ }^{35}$

Hart had granted the native head of Djapan, Kono Kusumo, a yearly stipend of $250 \mathrm{Sp}$. drs., and had permitted him to retain the title of $P$ atih on condition that he derived no further profit from his situation. The Mantries and Demangs were confirmed in their positions, and the religious officials were given the enjoyment of a regulated scale of marriage fees, as well as an optional collection of tithes. When Jourdan took control of Djapan, he suggested to Raffles that the right of collecting tithes should be abolished, and that the Government should grant the "priests" a fixed salary instead.

\section{Wirasaba.}

Hart had assessed the land rent of Wirasaba in 1812 at the very small sum of $6,420 \mathrm{Sp}$. drs. ${ }^{36}$ The Bandar and opium farms produced another $4,800 \mathrm{Sp}$. drs., which made a total revenue of $11,220 \mathrm{Sp}$. drs. When Jourdan assumed control of the district early in 1813 , he did not attempt to raise this assessment, although he told Raffles that he thought it was far too low. ${ }^{37}$ The general superintendence of the district was left in charge of the Patih, a man of low birth and mean accomplishments, who had received his appointment from the former Tumenggung appointed by the Susuhunan.

Jourdan's claim that the land rent assessment of Djapan and Wirasaba was too low was probably correct, for there were only slight arrears in payment during $1813 .{ }^{38}$

\section{Djipang.}

Lieutenant G. R. Pemberton of the 3rd Battalion Bengal Volun-

35 Loc. cit.

36 Loc. cit.

37 Loc. cit. On Djapan, Wirasaba and Djipang, see "Notes made by Captain Davy... when on a short trip through the Provinces of Djapan, Djipan, and Wierasabo, to take possession of them, in September 1812", Mack. Coll., Class), XIV, 6-8.

38 Hart assessed the land rent of the two districts at 16, $766 \mathrm{Sp}$. drs. According to Jourdan's Report, the latter added only 1,000 Sp. drs. to this, to cover the sawahs overlooked in Hart's survey. He may also have added a further small sum to the assessment for the lands devoted to other cultures. The total assessment of the two districts of Djapan and Wirasaba could, therefore, be calculated at about 18,000 Sp. drs. Between May 1, 1813, and April 30, 1814 , a sum of $16,896 \mathrm{Sp}$. drs. was actually collected from these districts. Java, Vol. 59. 
teers was appointed Resident of Djipang early in 1813, at a salary of $250 \mathrm{Sp}$. drs., together with a commission of $2 \%$ on the revenue collections. ${ }^{38}$ In the previous year when Davy had first taken charge of Djipang for the Government, the farms had yielded $2,400 \mathrm{Sp}$. drs. per annum, and a yearly contribution of money, ${ }^{40}$ thread, wax, buffaloes, and fish skins was made to the Government. ${ }^{41}$ Apparently Davy did not attempt to interfere in this arrangement, or to introduce a regulated system of land rent. When Pemberton arrived in the district early in 1813, he still found Djipang divided into six divisions, each under a Tumengsung, and quite independent of each other. ${ }^{42}$

Few details of Pemberton's assessment of the land rent of Djipang exist, but from the information which we possess of his revenue settlement of Wirosari, which was completed about this time, it seems safe to conclude that he eliminated the Tumenggungs, and granted leases to the Demangs.

\section{Wirosari.}

Pemberton took charge of Wirosari from Lieutenant J. Eckford, who was not able to take up his appointment because of illness. ${ }^{43}$ Pemberton immediately began a survey of the district in preparation for the introduction of a land rent system. ${ }^{44}$ Under the native government Wirosari had furnished a yearly contribution of 95 Sp. drs. in money, buffaloes, cloth, thread, wax, salt, onions and fish skins. In place of these, Pemberton established a land rent of 4,437 Sp. drs. ${ }^{45}$ From the assessment lists which have survived, it appears that he removed the Tumenggungs, and granted leases to the Demangs, who had several villages placed under their charge.

\section{Grobogan.}

This district had been conferred on the British Government by

39 De Haan, F., "Personalia", 625.

40 The money contribution was only $36 \mathrm{Sp}$. drs.

41 "Notes made by Captain Davy... on ... Djapan, Djipan, and Wierasabo", op. cit.

42 "Report on Djiepan by Mr. Pemberton", April 1, 1813, Mack. Coll., (Pr.), Vol. 21, No. 9.

43 De Haan, F., "Personalia", 542.

14 Various statistical tables relating to Wirosari drawn up by Pemberton are in the Mack. Coll., (Misc.).

45 Loc. cit. 
the first treaty with the Sultan in December $1811,{ }^{46}$ and had been given in charge to Pangeran Noto Kusumo. ${ }^{47}$ Except that we can infer from a letter which Raffles addressed to Minto in October 1812 that a settlement of the land rent was made on the Demangs, there is little information available regarding the first assessment of Grobogan. Because a detailed settlement was being introduced into the district early in $1814,{ }^{48}$ we can also infer that the leases to the Demangs were made for one year only.

\section{Pekalongan.}

During August 1812, the Resident of Pekalongan, F. E. Hardy, laid complaints against the Regent, who was quickly removed from his situation. ${ }^{49}$ Shortly afterwards, the Government decided that a monied rent "payable to Government direct" 50 should be introduced into the district, and Hardy was appointed "to reorganize Pekal[ongan] on a new plan".51 Raffles described Hardy as "a gentleman whose qualifications and acquaintance with the native customs and habits render him particularly adopted [sic] for the undertaking, and in whose principles the utmost confidence may be placed". ${ }^{52}$ Hardy did not, alas, live up to these expectations. He had been ordered to introduce a village settlement, but from a "misconception of the leading principles of the system" ${ }^{53}$ had mixed the old system of contingents and forced deliveries with the new land rent arrangements. This resulted, according to Raffles, in "a mass of confusion". 54

Hardy had calculated that the sawahs amounted to 3,557 jungs, $^{55}$

Deventer, M. L. van, N.G., pp. 314-9.

Under article 7 of the treaty, Ibid., 318.

Sub., 48.

Raffles to the Secret Committee, June 30, 1813, Java, Vol. 60, Part III; Sub., 37.

Raffles to the Secret Committee, Ibid.

De Haan, F., "Personalia", 561.

Loc. cit.

Sub., 37.

Ibid., 38.

"Paccalongang, 1812. Extract of Answer to the points of enquiry proposed by the Committee", by F. E. Hardy, Mack. Coll., (Pr.), Vol. 7, No. 2. See also "Statistic Table of the Population, Cattle 8 Produce in the District of Paccalongang", April 27, 1812, Ibid., No. 1. Rothenbühler estimated the sawahs of Pekalongan in 1798 at 3,693 jungs, "Extracten uit eene Missive van den Resident van Pekalongan, F. J. von Rothenbühler...., gericht aan Mr. Sebastiaan Cornelis Nederburgh .... (1798)", Eindresumé, II, Bijlage II, 134. 
but he did not grant leases for them either to the Bekels as instructed, or to the cultivators themselves. This confused settlement had been made for one year, and Raffles was forced to honour it. ${ }^{58}$ But Hardy was removed from his post, and on May 18, 1813, J. C. Lawrence was appointed to succeed him. ${ }^{57}$ It was not until the following month that Lawrence actually took control of Pekalongan, ${ }^{58}$ with instructions to collect information in preparation for a new assessment of the land rent when Hardy's settlement expired. A small number of Dutchmen were formed as a Commission to assist him in this task. However, before we discuss Lawrence's settlement of the land rent in Pekalongan, it is necessary that we examine the progress of Yule's settlement in Bantam. ${ }^{58}$

\section{Bantam.}

Through the reports of the Mackenzie Commission, of Crawfurd and of Horsfield, ${ }^{80}$ Raffles had become convinced by the beginning of 1813 of the Government's sovereign rights to the ground. It was upon that principle that he had justified the sale of lands, and it was upon the same concept that the land rent system was based. From the principle of sovereignty flowed the notion of "hiring", of "leasing" and of "renting" the ground. ${ }^{61}$ It provided, moreover, the theoretical justification for the removal of the top layers of the native society. In the settlements of the land rent in the Transferred Districts, Raffles had seen how easily the Tumenggungs could be set aside, and lands leased to the Bekels and Demangs. As his ideas on the land rent question developed during 1813, he decided that it was upon the first group, the Bekels and Lurahs, that he would base his settlement. But, as we have already seen, Raffles had no such ideas in the middle of 1812 when he ordered Yule to effect a land revenue settlement in Bantam. Yule had merely been instructed to compensate the Regents either by grants of land in property or lease, and to distribute the remainder of the lands according to some plan that Yule himself was to devise.

56 Sub., 38.

57 De Haan, F., "Personalia", 595.

58 Ibid., pp. 561, 595.

59 See pp. 164-7 for a discussion of the Pekalongan settlement.

60 "Queries addressed to Dr. Horsfield by Colonel Mackenzie with the Answers On the Culture \&s Division of Lands in Java, June 1812", Mack. Coll., (Pr.), Vol. 13, No. 11.

61 Norman, H. D. Levyssohn, op. cit., 189, footnote 1. 
During 1812, Yule seems to have been fully engaged in making a survey of the Lowlands of Bantam, ${ }^{62}$ and investigating the land tenures preparatory to a final settlement of the land rents. On the question of tenures, he reported to Raffles in November 1812: ${ }^{63}$

It seems allowed that all property in the soil rests exclusively in the hands of the Sovereign power - but in consequence of its having been long customary to confer grants of land upon the different branches of the Royal Family and other chiefs \& favourites about Court, a very small proportion of the Country is now left without some claim[an]t or other.

The [pusakas] ${ }^{64}$ granted to the relations of the Sultan were considered as real property, \& sometimes descended to the heirs of the Family, \& at others were alienated from it by private sale.

To effect a transfer of this nature, the previous sanction of the Sultan was necessary, after which the parties waited upon the High priest, or Manchaboomee, who made the necessary enquiries, and delivered the title deeds to the purchaser, in which was specified the situation, extent, boundaries $\&$ price of the lands sold. A register of sales was kept by the priest the purchaser paying the fees, and it rarely occurred that lands sold in this manner, were ever resumed by the Crown without some adequate compensation being given to the purchaser.

[Pusakas] given to chiefs for services performed, were resumable at pleasure, and always reverted to the Crown, on the demise of the chief to whom they had been granted; in all other respects the same privileges were annexed to them as to the former. Previous to 1810, the [pusaka] lands are said to have paid no revenue to the Sultan either in money or kind - the proprietors being only bound to attend the Sultan with their dependants on all occasions, whether called for the purposes of war, for the protection of property, or for the construction of public works.

At the above period, the Dutch assumed the entire management of the Low Countries, $\&$ it was ordered that $1 / 5$ of the produce of paddy $\&$ cotton should be collected on account of

"Table of the Districts of Coast Lands Bantam - not including the Sultan's Dominions", Mack. Coll., (Misc.).

(i3 "Statistic Memoir on Bantam by Major Yule", Mack. Coll., (Misc.), The Memoir is undated, but in the "List of Papers illustrative of the Proceedings \& Progress of the Commission instituted by Order of Government of the 21st January 1812 for the Affairs \& State of Java down to the 15th July 1813", Mack. Coll., (Pr.), Vol. 35, No. 22, it is dated November 1812. Raffles cited the passage in Sub., pp. 123-6, but I have followed the manuscript copy.

(i4 On Yule's references to pusakas, Eindresumé, II, Bijlage A, pp. 11-2. 
Government from all lands whatever - the same as had formerly been collected by the Sultan from the crown lands only.

All other crops, including sugar cane, sweet potatoes, [coconuts] \& other fruit trees, seeree leaves \&c. \&c. are said to have paid no revenue either to the Sultan or to the holders of [pusakas] having been left at the disposal of the cultivators. It is allowed, however, that the cultivators were always in the habit of making presents of every article in its season. The holders of [pusaka] lands were very seldom occupants - they generally remained about Court, and on the approach of the paddy harvest deputed agents to collect their share of the crop, but what proportion this share used to bear to the whole produce does not seem to be well defined. It is by one stated at $1 / 5$, by another at $1 / 10$, and by some (which I suspect to be nearest the truth) as much as the cultivator could afford to pay, the agents of the proprietors being the judges of the quantity.

The proprietors of [pusakas] have also a claim to the services of cultivators. A certain number of them [are] always in attendance at the houses of their chiefs, and on journeys they are employed in carrying their persons \& baggage.

The proprietors of [pusakas] do not let their lands for specific periods; the cultivators are liable to be turned out at pleasure, and the people ejected have no claims to compensation for improvements made while in possession, such as water-courses, plantations of fruit-trees made by themselves, or their parents. On the other hand, the cultivators may throw up their lands when ever they think fit to do so.

Lands not [pusaka] used to pay the same proportion of the produce to the Sultan as the others did to [the] proprietors, but the cultivators of the royal domains laboured under greater disadvantages than the others. Every chief or favourite about Court had authority to employ them in the most menial offices, and chiefs possessing [pusakas] often spared their own people, and employed others. The Sultan always had a right to enforce the culture of any article which he thought proper to direct, and in such cases a price was fixed upon the produce, which was generally very inadequate.

Yule, who was familiar with the Bengal revenue settlement, seems to have been naturally disposed to a Zamindari type of settlement in Bantam. Some sort of provisional arrangement was made during the latter half of 1812 for the collection of a land rent, ${ }^{6,5}$ and early

(15 In a letter to Assey, dated February 28, 1813, (Java Public Consultations, March 12, 1813,) Yule referred to "the last collection of Land rent" in Bantam, clearly indicating that a collection was made during 1812 . But it 
in 1813, apparently with encouragement from Raffles, he began renting lands in large parcels to the rural nobility. This was effected after he had granted 50 jungs of land, as well as the pusakas formerly in their possession, to the members of the family of the late Sultan Majifir Mohamed Ali Udin.. ${ }^{60}$ But as the land rent settlement had withdrawn from them the gratuitous services of the people, these lands had become neglected. ${ }^{67}$ The old Sultan's family had, therefore, pleaded with Yule to give them regular salaries instead of lands. Yule advised Raffles to agree to this, and to grant to one of the Regents, the Pangeran Sura Mangala, who was likely to suffer under the new revenue system, a yearly sum of $5,000 \mathrm{Sp}$. drs. He also thought that compensation should be given to the son of the exiled Pangeran Ahmat. ${ }^{68}$

Yule's first systematic assessment of the land rent in the Lowlands of Bantam made in February 1813, is on page 109 . $^{\text {(i8 }}$

In entering into a contract with the farmers, the Government relinquished all claims to feudal service from the people, and proposed to transfer the lands in "entire property" to the renters. ${ }^{71}$ The latter, in their turn, agreed to keep the roads and bridges in a good state of repair, and to make labour available when the Government demanded it. This labour, was, of course, to be paid for by the Government at a "reasonable rate". The farmers also were to pay rent to the Government on the following terms:

Trukahan . . . . . . . . . . 8 Sp. drs. per jung. Parangaran . . . . . . . . . 4 Sp. drs. per jung. Gaga, Tegal, Dukuh, or any other land not of the description of the first two $3 \mathrm{Sp}$. drs. per jung.

Rents were to be paid half yearly, in June and December, but lands

was certainly a haphazard arrangement, because it was not until early in 1813 that anything like a systematic assessment was possible.

66 Loc. cit.

67 Loc. cit.

(i8 Loc. cit. On Pangeran Ahmat, p. 34.

i: I have compiled this table from two others, one in Java Public Consultations, March 12, 1813, and the other published by Deventer, M. L. van, N.G., 15. There are some slight differences between the manuscript table and Van Deventer's, and I have followed the former in all such cases. But Van Deventer's table has a fuller list of the names of the farmers .

71 Deventer, M. L. van, N.G., pp. 16-7 has printed, rather inaccurately, a copy of this contract. I have followed the manuscript copy, Java Public Consultations, March 12, 1813. 


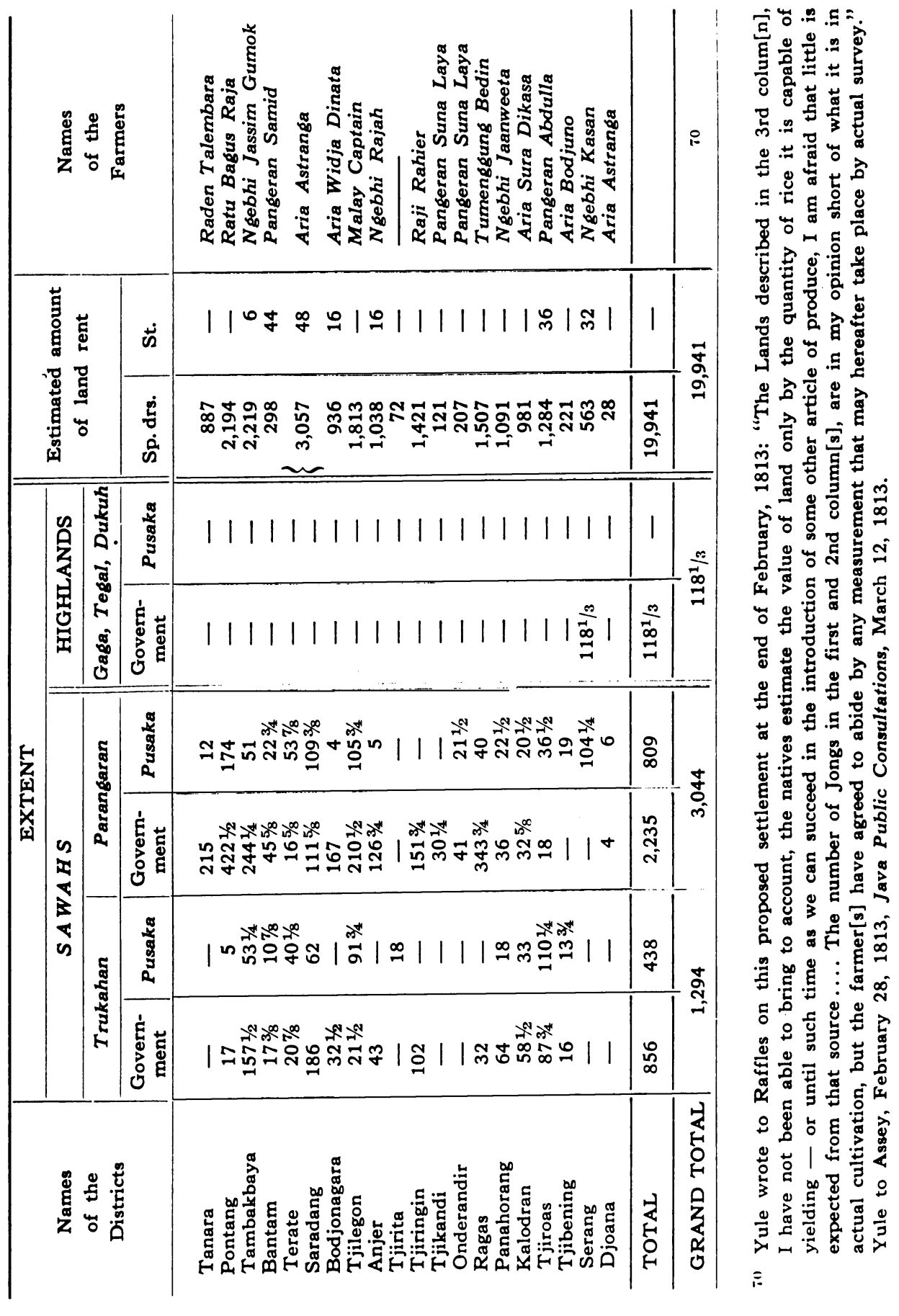


that were not able to be brought into cultivation because of the lack of labour, or from the nature of the soil, were not to be assessed. Remissions of rent were also to be granted for failures of crops where these were not the fault of the cultivators. The contract concluded:

It being the intention of Government to extend as far as possible to the lower classes the benefit of this arrangement, the Renters of the districts shall bind themselves, either to cultivate the grounds at their own expense, or to sublet them at a moderate $\&$ fixed rent to the cultivators themselves, and on no account to other chiefs for the purpose of renting them out at an advance rate. ${ }^{72}$

Nothing shows quite so clearly as this clause, the strange mixture of ideas which Raffles had on the land rent system at this time. Although the contract was drawn up by Yule, it was approved by Raffles in Council on March 5, 1813, ${ }^{73}$ and may, therefore, be taken as fairly representing his views on the subject. The whole spirit of the contract suggested a Zamindari settlement, as it was made on the Pangerangs, Tumenggungs, Arias and $N$ gebhis, and others of high rank. ${ }^{74}$ Raffles' approval of it seems strange when we recall his instructions of the previous April, that the Regents were to be given grants of land, and the remainder distributed. It was doubtless his failure to specify the class upon whom these surplus lands should be settled, that made Yule base his settlement on persons of the Regent class. This was the natural course for Yule to follow because of his familiarity with conditions in Bengal. Certainly his letters to Raffles on the subject of the land rent imply Raffles' attachment to the Zamindari principle. ${ }^{75}$

Another condition in the contract with the renters of the Bantam Lowlands was that "no taxes or services of any kind" were to be exacted from the people. This was merely paying lip-service to an ideal, for it was quite clear from the earlier clauses of the contract, that the renters were to have full rights to demand the labour of the people on their lands. Otherwise cultivation would have been impeded.

72 Loc. cit.

73 Raffles' reply to Yule appears as a marginal note of March 5, 1813, to Yule's letter of February 28, 1813, Java Public Consultations, March 12, 1813.

74 Deventer, M. L. van, N.G., pp. 147; LXXVIII.

$7 \pi$ Wright, H. R. C., "Muntinghe's Advice to Raffles...,", op. cit., p. 228. 
When Raffles' approved Yule's settlement on March 5, he also sanctioned the monied salaries proposed for the family of the Sultan Majifir Mohamed Ali Udin. But he reserved discussion on the subject of the compensation due to Pangeran Sura Mangala, until he himself visited Bantam in person. ${ }^{76}$ Raffles, in fact, left Batavia for Bantam only a few days later. He arrived at Serang on March 18. There he began negociations with the Sultan for the cession of the Bantam Highlands. After some initial hesitation, the Sultan agreed to the cession on condition that he was paid an annual salary of $10,000 \mathrm{Sp}$. drs. He was also to be given $3,000 \mathrm{Sp}$. drs. to pay off his current debts. ${ }^{77} \mathrm{~A}$ week later, Raffles instructed Yule to put the deed of cession into effect. On the subject of the land rent, he wrote: ${ }^{78}$

The establishment of a Land Rent has already been approved in the Lowlands, and it would be advisable that the same system should be adopted throughout the whole of the Country. Considering, however, that all the advantages of the new system cannot be perfectly understood by the native inhabitants at its first introduction, \& that the present reduced state of the country so lately restored to tranquillity, can[not] admit of a fair rent being immediately paid for the lands, it is thought advisable that the leases of the Farms, at such rates as may now be established, might be for three years. Some objection may arise [from] this arrangement, of which the Lieutenant Governor is not exactly aware, and he is therefore desirous of receiving your opinion on the subject. If leases for one year would be equally satisfactory to the Renters, that period of time would enable a more perfect knowledge of the value of the lands to be acquired, and would, therefore, be preferable, but it is not impossible that the adoption of so short a period might shake the confidence of the inhabitants in this arrangement now to be concluded, that consideration may render it objectionable.

A month later, Yule reported his failure to lease the Highlands on similar conditions to those of the Lowlands. "I have not been able to find chiefs willing to rent any of the High Districts on condition

76 Raffles' marginal reply to Yule, March 5, 1813, op. cit.

77 The various documents concerned with cession of the Highlands of Bantam were recorded in Java Public Consultations, April 21, 1815. See also, Eindresumé, II, Bijlage A, 16.

78 Assey to Yule, March 26, 1813, Bengal Civil Colonial Consultations, June 12, 1813. 
of residing upon them," he wrote, ${ }^{79}$ "and I am afraid that I shall be obliged to descend to the lower orders and let out the lands without any intermediate rank between the Government and the peasantry." Another difficulty was that advances had already been made by the people in the Highlands to the Sultan before the cession. Yule told Raffles that it would be necessary, therefore, to suspend the establishment of "a fixed monied rent" in the Highlands until the beginning of 1814 , and to receive the balance due from the Highlands either in money or kind. ${ }^{80}$ Raffles replied promptly. "It is the wish of the Government", he stated, "that the lands should be let as closely to the cultivator as possible, where the nature of society does not render it necessary to place the chiefs in these situations of Renters". ${ }^{11}$ The reply was dated June 7, and shows clearly the shift of Raffles' ideas. He now turned his attention to introducing the land rent system into the other districts of Java.

79 Yule to Assey, May 28, 1813, Java Public Consultations, June 7, 1813.

so Loc. cit.

S1 Raffles' reply to Yule appears as a marginal reply on Yule's letter of May 28, 1813, Ibid. 


\section{CHAPTER VI \\ MINUTES AND REPORTS ON THE LAND RENT SYSTEM 1813}

The successful establishment of the land rent system in the Transferred Districts and Bantam had shown Raffles that the system could be extended to the districts along the North East Coast of Java. In a despatch to the Secret Committee at the end of June 1813, he claimed that for some time he had had the idea of introducing a monied rent into the whole of Java. His opinion about the wisdom of the idea had been confirmed by the successful working of the system in the Transferred Districts. ${ }^{1}$

The result of ... [that] measure has fully answered the utmost advantages that were anticipated. By being relieved from the oppression of feudal service, and able to calculate on realizing to themselves the produce of their labour, the population of these Districts have extended and increased their agricultural pursuits; no instance has been known to occur of dissatisfaction among them, the internal police and tranquillity of the country have been easily maintained, and no arrears have been experienced in the Revenue, the amount of which in the approaching resettlement for a term of three years is reported to be likely to increase. ${ }^{2}$

Raffles has been criticized by Dutch historians for introducing his land rent system into Java in haste. But this criticism has

1 Compare Raffles' statement in October 1814: "The operation of the system of the Landrevenue in the districts of Bantam was calculated to encourage the execution of that system in the other parts of the Island, and it was on that favorable experience that we were principally induced to extend the operation of the same principles to the other districts of Java", Raffles to Moira, October 6, 1814, cited by Deventer, M. L. van, N.G., LXXVII. Another copy of the despatch, Raffles to Nugent, is in Java, Vol. 70. In his Minute of June 14,1813, Raffles stated that he had had the idea of introducing the system of land rent throughout Java as early as the fall of Yogyakarta, a year earlier. Sub., 276. See also Sub., pp. $271-2$.

$\simeq$ Raffles to the Secret Committee, June 30, 1813, Java, Vol. 60, Part III. 
obscured a more important question - why, in fact, did he delay so long? For with the exception of Bantam and the Transferred Districts, it was not until the middle of 1813 , almost two years after Raffles had assumed control of the colony, that the system of land rent was introduced into Java as part of a coördinated plan of reform. Financial difficulties would have justified such a reform some months earlier, but Raffles did not begin to play his rôle of land reformer until the latter half of 1813 . What were the reasons for this delay?

In the first place, Minto had left positive instructions that any major reform of the land system of Java had to be undertaken only after mature deliberation. Because of this, although he had attempted to hasten the work of the Mackenzie Commission, Raffles had to await the Commission's final report before attempting reform. Secondly, there was considerable doubt during 1812 and 1813 about the future of the colony. Travers' Journal is full of the rumours that were current in the island about the colony's future. Everyone expected the arrival of Maitland as Governor, and the transfer of Java to the British Crown. Raffles stated in his Minute of June 14,1813 that the introduction of the land rent system had "been delayed for the last six months, in the expectation of information from Europe," and that he had introduced it in the middle of 1813 only because a further delay would have resulted in its postponement for ever. ${ }^{3}$ The third reason which made Raffles hesitate about extending the system throughout the island, was that he was expecting word from Bengal approving the measures which he had taken in Bantam. As early as May 1, 1812, he had forwarded the instructions which he had given to Yule for the revenue settlement of Bantam, and during the remainder of 1812 he waited for the Supreme Government's approval. The enclosures in Raffles' despatch, however, never arrived, ${ }^{4}$ so that he was waiting in vain. Five months later, in October, he had again reported to Minto on the introduction of a land rent system in Patjitan and Kedu, and this time he received a prompt and enthusiastic reply. ${ }^{5}$ Minto's despatch was written early in the New Year, and it was undoubtedly the arrival of this despatch that prompted Raffles to extend the system throughout Java. On

3 Sub., 276.

4 Bengal Civil Colonial Consultations, January 8, 1814.

5 See p. 98. 
May 28, 1813, he presented his first long Minute on the subject to the Java Council.

\section{Raffles' Minute of May 28, 1813."}

The introduction of the land rent system into the Eastern Districts of Java at this time was part of a general plan of reform in the administration of the island. One part of the plan was for a reduction in the Civil Establishments, which was expected to produce a financial saving, and the other was to revolutionize the collection of revenues from the Javanese, and increase the area of land under cultivation. As we have seen from the financial estimates for the year 1812/13, Raffles had calculated upon the continuation of the collection of recognition money, contingents and forced deliveries from the Regents. ${ }^{7}$ But in most cases these estimates proved to be visionary. In May 1813, the Accountant-General Bauer reported that serious arrears in payment had occurred in Demak, Djapara and Kudus, ${ }^{8}$ and he had earlier informed Raffles that the greater number of the Regents had not paid their recognition money for the year 1811 , let alone for 1812 and $1813 .^{\circ}$ The new land rent system was introduced in order to overcome these irregularities.

In his Minute of May 28, Raffles contended that the old system had benefitted no one. It had oppressed the Javanese by the exaction of feudal services, while the forced deliveries at inadequate rates had destroyed their incentive to increase cultivation. The new "enlightened" system would produce "industry, knowledge and happiness" by the abolition of deliveries and services. Instead, an annual rent would be exacted, payable in cash, or where necessary, in kind.

It is obvious that the first consequence of this System will be an amelioration in the condition and happiness of the people by gradually removing them from the vassalage and slavery in which they at present exist, and by teaching them to acquire an idea of personal property with which they are as yet unacquainted. That it will procure to Government a fixed and certain Revenue which tho' less in amount than the estimated value of the contingent $[s]$ now delivered, would in reality be

" Java Public Consultations, May 28, 1813.

7 See p. 42.

8 Bauer to Assey, May 4, 1813, Java Public Consultations, May 14, 1813.

- Same to Raffles, October 10, 181[2], Ibid., April 9, 1813. 
more available, and consequently more valuable - that it will thereby enable Government to calculate on actual resources and that it will remove the causes and opportunities of inferior irregularity and oppression by effectually preventing the employment of the labour or property of the people without an adequate compensation $\&$ payment. ${ }^{10}$

Raffles did not enter into any details about the collection of rents, although he stated that the pattern of the Bantam settlement would be extended "by degrees throughout the Island". The position of the Regents in the settlement was not discussed. But two weeks later, he drew up another Minute, and in this he stated his intention of dispensing with them altogether in the collection of the land rent.

\section{Raffles' Minute of June 14, 1813.11}

Raffles thought that the revenue of the Government had suffered in the past because of the "number of intermediate hands" through whom it was collected. ${ }^{12}$ He decided, therefore, that the Government would undertake the immediate superintendence of the lands and collect the rents "without the intervention of the Regents". ${ }^{13} \mathrm{He}$ considered the Government had the right to remove the Regents from the revenue administration because of its sovereign rights to the ground in Java. This sovereignty established the "justice and right of interference". ${ }^{14}$ Raffles cited from Mackenzie's report in support of this contention. The Regents and Demangs were to be employed in police duties, and granted salaries. In addition the Regents were to receive compensation in lands for the loss sustained in their emoluments, and some of the Demangs would, of necessity, also be granted leases. But as a general principle, Raffles thought that the lands should be let "as near [to] the actual cultivator as possible," "is generally upon the Bekels and Lurahs.

[I]n every instance where the Bakal, or head man of the peasantry, is found able to rent a small lot, parcel, or ground, he should have a preference; unless such preference would, from local circumstances and inquiry, be found to clash mater-

10 Minute of May 28, 1813, op. cit. Italics mine.

11 Sub., pp. 253 et seq.

12 Ibid. 253.

13 Ibid., 261.

14 Ibid., 256.

15 Ibid., 267. 
ially with the interests of a Native Chief, whom it is politically advisable to provide for on the spot. ${ }^{16}$

Raffles realized that he would have to proceed cautiously in introducing the new system. The Regents would probably resent losing their status and wealth, although their influence over the people would probably not cease immediately. ${ }^{17}$ The introduction of the land rent system would, therefore, depend upon the European officers, who were to be allowed some freedom in interpreting their instructions. ${ }^{18}$ Where lands could not be let in small parcels to the Bekels, larger leases were to be granted to priyayis of higher rank, but only as a temporary measure - until the people had from "their actual possession of the land, acquired some knowledge of the right of property". ${ }^{18}$ To avoid the evils of perpetual settlement, leases were to be granted for periods not exceeding three years. Rents were to be collected in money, for Raffles thought that the land rent system would produce large amounts of specie for his Treasury. ${ }^{20}$ But in some cases rice was to be accepted as payment.

In concluding his Minute, Raffles referred to the recommendations made by the Dutch members of the Land Tenure Commission that lands should be sold or leased to Europeans. ${ }^{21} \mathrm{He}$ said that he had not accepted these proposals because he conceived "the admission of Europeans to rent lands in the interior, would be too great a breach of the habits and customs of the people at the first introduction of a change". ${ }^{22}$ Leases to the Chinese were also thought unadvisable, because of their extortion of the population. ${ }^{23}$

On the question of the coffee cultivation, Raffles decided that the gardens in the Eastern Districts would be leased on the same conditions as the other lands, but that the exclusive cultivation for the Government would be continued in the Batavian Regencies and in the Priangan. In order to encourage the free cultivation of coffee

18 Ibid., pp. $267-8$.

17 Ibid., 267.

18 Ibid., pp. $267-8$.

19 Ibid., 268.

20 "It appears to me beyond a doubt", he wrote, "that the introduction of a money rent will bring forward a large proportion of coin, which, at present, lies unemployed....", Ibid., 266.

21 Ibid., 270. Raffles did not refer specifically to the Commissioners, but there is no doubt that he had their proposals in mind.

22 Ibid., 270.

23 Loc. cit. 
on the rented lands, the Government agreed to purchase it at the rate of $3 \mathrm{Sp}$. drs. per pikul, the price paid in the Batavian Regencies. ${ }^{24}$ Altogether, Raffles expected that the land rent in the Eastern Districts would yield an annual sum of 2,500,000 Sp. drs. ${ }^{25}$

\section{Crawfurd's Report on Land Tenures.}

Raffles' decision to base his land rent settlement on the Bekels and Lurahs was undoubtedly influenced by a long report sent to him by Crawfurd in May 1813. In this report, entitled "Remarks on the nature and Condition of landed tenures under the Native Government of Java, with some suggestions for the improvement of the Land Revenue in the territories of the European power",20 Crawfurd reiterated his contention that proprietary rights in the soil were "unquestionably vested in the Sovereign," 27 but examined in more detail his argument that the Bekels possessed certain hereditary rights to the ground. In general, Crawfurd had modified his earlier opinion.

The tenure of the Bakal is hardly less insecure than that of the cultivator: - like him, he may be removed at the pleasure of his immediate superiors. The nature of this, however, in some respects, contributes to check a very arbitrary exercise of this authority. From the advantages acquired by actual possession and the capital thus accumulated, the Bakal, generally speaking, becomes the fittest and ablest person to pay the superior the full rent of the lands: - it is, therefore, the advantage of the latter not to remove him, and thus the interest of his superior gives to his situation, at least, a certain degree of stability. This security, however, is far from approaching to any degree of certainty.

Nevertheless, so far as the Javanese cultivator was concerned, the Bekel was regarded as "the actual land-holder", and it was, there-

24 Ibid., 274. On the arrangements for the so-called Blandongs, Ibid., 275.

25 Ibid., 276.

26 Copies of this report appear in several places. One is in "Papers relating to Java, circa 1815", Add. Mss., 30,353; another in Java, Vol. 69; and another in Mack., Coll. (Pr.), Vol. 21, No. 7, which copy carries a marginal date of May 17, 1813. Raffles cited from the report, Sub., pp. 82-98.

27 See also Crawfurd, J., History of the Indian Archipelago, (1820), III, pp. 45 et seq.; Crawfurd, J., A Descriptive Dictionary of the Indian Islands...., sub "Tenure of Land", pp. 429-30. 
fore, advisable for the Government to deal with the Bekels in any land settlement.

Crawfurd thought that a permanent interest in the soil should be established in Java, but not as in Bengal by conferring inalienable proprietary rights on one class, at least not immediately. Lands should be leased to the Bekels in the first instance, for three, four or five years. After that, a more permanent arrangement could be made. He thought it would be of little use granting leases to the Demangs as that would result in intermediate tenantry and be prejudicial to cultivation. In this connection he cited Colebrooke, who had described the evils caused in Bengal by the Zamindars subletting their lands to middlemen. ${ }^{28}$ Crawfurd argued that any interference on the part of officers of the Government in the private concerns of the lessors and the cultivators would be impracticable, and even if practicable, would be "injudicious". The landholders were to be free to demand what rents they liked, but a clause was to be written into their contracts stipulating that they had to lease lands directly to the cultivators. The revenues of the Government should "in every instance be a fixed money rent". With security, Crawfurd thought that these rents could be increased gradually.

\section{Muntinghe raises objections.}

It was not until the end of July that Muntinghe submitted any detailed objections to Raffles' plan. ${ }^{29}$ Dismissing the question of the benefits which the land rent system was expected to confer upon the Javanese as a matter of secondary importance, ${ }^{30}$ Muntinghe concentrated his criticism on the proposals for eliminating the Regents. He thought that the compensation proposed by Raffles would be adequate to cover their economic losses, but would not satisfy them for their loss of power and authority.

[A]s it is not uncommon to see persons, in the highest state of civilization, more attached to vanity, to empty titles, and

28 Colebrooke, H. T., Remarks on the Husbandry and Internal Commerce of Bengal, (1806), 64. "Wherever the system of an intermediate tenantry subsists, the peasant is indigent, the husbandry ill managed". It seems likely that Colebrooke's views influenced Raffles in this matter. He referred to "Mr. Colebrooke's excellent account of its [Bengal's] husbandry" in $H$. of J., I, 148.

29 Minute by Muntinghe, July 28, 1813, Sub., pp. 279 et seq.

30 Ibid., 280. Compare the view of the 1803 Commission, Deventer, S. van, L.S., I, pp. 13; 88. 
prerogatives, than to their real and more substantial interests, it seems hardly possible to expect, that the half-civilized race of Javanese Regents will submit, without some degree of discontent and dissatisfaction, to such a material reduction of their personal pride and consequence. ${ }^{31}$

He advised that the land rent system should be introduced cautiously, so that the people might become accustomed to its beneficial effects. ${ }^{32}$

In fact, Muntinghe, because of his considerable knowledge of native society, ${ }^{33}$ thought that Raffles' plans would remain on paper. If the Regents were to be continued in police duties, and this would be necessary to avoid discontent, whom, he asked, would control the power of police with regard to the exaction of feudal services? Who would prevent the people from continuing to show the same respect to their chiefs as formerly? Who would prevent them from bestowing upon their chiefs the same services and contributions? "The system of feudal services may ... be abolished with regard to Government," he wrote, ${ }^{34}$ "but it seems difficult to prevent its continuation with regard to the Native Chieftains." In any case, it would be necessary to grant leases to the Demangs and Bekels, and they would exact the same services as formerly. ${ }^{35}$ Muntinghe also questioned Raffles' expectations of the financial benefits of the new system. He thought there would be considerable payments in rice if lands were leased exclusively to the peasants, because they would prefer to cultivate that commodity. As an article of commerce, this would prove very unprofitable to the Government. ${ }^{36}$

\section{Raffles aware of objections.}

Raffles himself had been aware of these objections. A month before Muntinghe had submitted his Minute, he had written to the members of the Secret Committee informing them of the proposed reform, ${ }^{37}$ and of the objections which he thought might be raised against it. There was the risk attending the introduction of a change

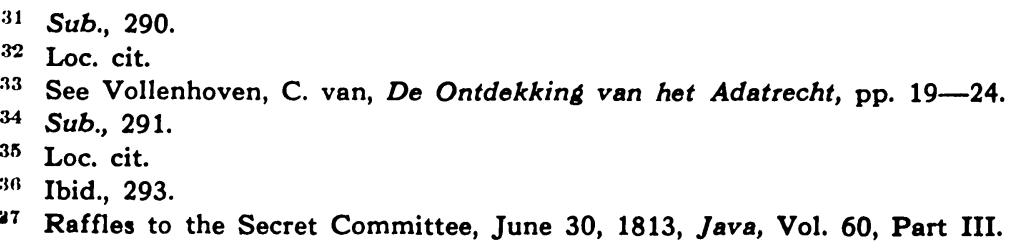


in the long established customs of the people; the danger of creating discontent among the chiefs; and finally, there was the question of the national character - whether the Javanese who had few immediate wants, and had long been subjected to "feudal" bondage, would benefit by a change of system. To the first objection, Raffles pointed to the facility with which the land rent system had already been introduced into the Transferred Districts. In any case, he continued, the risk was off-set by the "absolute necessity" that existed for establishing a more fixed and reliable revenue. $\mathrm{He}$ thought moreover that the compensation granted to the Regents would be adequate, and would prevent them from being discontented. Their police duties would enable them to preserve their outward rank, and the Government was prepared to make substantial sacrifices in the first settlement in order to secure their good-will. So far as the indolence of the Javanese was concerned, he contended that the new system by abolishing forced services, contributions and deliveries, and establishing rights to the soil, would produce "an independent body of landholders" interested in increasing their wealth. This would lead to an extension of cultivation and general prosperity. ${ }^{38}$ Raffles informed the Secret Committee of his intention of introducing the land rent system "to such [an] extent, and in such [a] gradual manner as may appear secure and advisable with reference to the peculiar situation of the Chief in each District respectively". ${ }^{38}$ Although he intended to proceed in this way, he stated that he was still eagerly awaiting the final report of the Land Tenure Commission. Unfortunately this report was never completed.

Mackenzie leaves Java, and the Land Tenure Commission ends its work.

The members of the Mackenzie Commission were diverted from their investigations into the land tenures of Java, first in September, and again in November 1812, when Raffles appointed them to act as Commissioners for the sale of lands. Rothenbühler, Knops and Lawick van Pabst had accepted the second appointment with some reluctance, because of the interruption it caused in their investigations. ${ }^{40}$ They need not have worried, because by the beginning of

38 Loc. cit.

39 Loc. cit.

40 Knops to Mackenzie, November 28, 1812, Mack. Coll., (Pr.), Vol. 74, No. 53; and same to same, January 19, 1813, Ibid., No. 55. 
1813, Raffles had decided that the useful work of the Mackenzie Commission was finished. On January 22, he told the Java Council of his intention of dissolving it at the end of the following month. ${ }^{41}$ Three days later, the Commissioners were informed of the decision, and asked to arrange their materials for the compilation of a final report by February 28. ${ }^{42}$ The Dutchmen appear to have taken little notice of this directive, but continued their routine work. Knops and Lawick van Pabst were busy in Tuban at the end of January, ${ }^{43}$ and wished to investigate the Oosthoek because Rothenbühler's illness had prevented him from going there. ${ }^{44}$ During February, Mackenzie began to grow uneasy when he did not receive information from the Commissioners, and on February 24 he addressed a circular letter to them asking for the results of their investigations. ${ }^{45} \mathrm{Knops}$ and Lawick van Pabst did not reply until the latter half of March, when they urged the necessity of extending the investigation to Gresik, Madura and its adjacent islands. ${ }^{46}$ Mackenzie informed Raffles that his instructions had not been obeyed.

I have no account whatever nor have I been apprized under what arrangements of the Committee these members consider themselves authorized to proceed at this period to the investigations of the further Eastern Districts without some previous sanction that I have not been apprized of. I consider according to the late orders that it was the intention of Government that the members closing their enquiries on the 1 st March, should transmit the Reports of their Divisions separately; $\&$ in consequence I directed them to be communicated to me both as the regular channel for transmission to Government \& also to enable me to make up the Report required from myself; as it will readily occur that without a communication of the materials resulting from this Plan of Enquiry my means of reporting must be very limited $\&$ indeed of little utility. ${ }^{47}$

41 Java Public Consultations, January 22, 1813.

42 See Circular letter from Mackenzie to Rothenbühler, Knops and Lawick van Pabst, February 24, 1813, "Letter Book [of the] Commission", op. cit., Letter No. 21.

43 Knops to Mackenzie, January 19, 1813, Mack. Coll., (Pr.), Vol. 74, No. 55. 4.4 Loc. cit.

45 Circular letter from Mackenzie to Rothenbühler, Knops and Lawick van Pabst, February 24, 1813, op. cit.

46 See Mackenzie to Assey, March 24, 1813, "Letter Book [of the] Commission", op. cit., Letter No. 23.

47 Loc. cit. 
Raffles apparently gave permission for the Commission to continue for a short time, for reports on the Oosthoek prepared by Knops were eventually forwarded to Mackenzie. ${ }^{48}$ The Commission drew to a close sometime late in May, or early in the following month. ${ }^{48}$ During June, Mackenzie was busy preparing his final report, ${ }^{50}$ but in the middle of July, before it was anywhere nearly completed, he asked for permission to proceed to India. ${ }^{51} \mathrm{He}$ told Raffles that he would finish it there.

Mackenzie left Java on July 18. Previous to his departure, he forwarded the various materials relating to the Commission's work to the Revenue Department, ${ }^{52}$ and sent some statistical information directly to Raffles. ${ }^{53}$ When he arrived at Calcutta, Minto readily consented to arrange extended leave of absence for him, so that he could remain there and complete his report. ${ }^{54}$ During the closing months of 1813 he was at Serampore, and on December 14 he forwarded a copy of his revised "Journal" 55 to the Supreme Government, with the request for further time to complete the report. ${ }^{56}$ This was granted. ${ }^{57}$ But how long Mackenzie remained at Calcutta at work on the report is not clear. In March 1814, the Supreme Government was still awaiting it, ${ }^{58}$ and from various dates on the Mackenzie manuscripts it seems that he continued collecting

48 "Notices 85 Remarks Descriptive 8 Statistic in Some of the Districts of the East Point of Java written in 1812-1813", Mack. Coll., (Misc.). There are eight reports in all, some of them highly interesting.

44 Sub., 276.

50 Mackenzie to Raffles, June 16,1813, "Letter Book [of the] Commission", op. cit., Letter No. 25.

51 Mackenzie to Assey, July 13, 1813, Ibid., Letter No. 26.

52 "List of Papers illustrative of the Proceedings \& Progress of the Commission....", op. cit.

53 In a letter to Assey dated July 15, 1813, ("Letter Book [of the] Commission", op. cit., Letter No. 27) Mackenzie enclosed two statistical tables for Raffles. One of them was published by Raffles, $H$. of J., I, opposite p. 62. Muntinghe in his Minute of July 28, 1813, (Sub., 292) referred to "the valuable information which has lately been collected by Colonel M'Kenzie, and delivered by him to Government, with regard to the statistics of Java."

54 Minto to Abercromby, August 21, 1813, Bengal Civil Colonial Consultations, August 21, 1813.

55 "Report and Journal ... of Lieutt. Colonel Mackenzie....", op. cit.

56 Mackenzie to Tucker, December 14, 1813, Bengal Civil Colonial Consultations, April 30, 1814.

57 Consultations, Ibid.

58 Secretary Supreme Government to Assey, March 19, 1814, Java Public Consultations, July 13, 1814. 
material for it, particularly from Dutch printed sources, as late as 1815. Possibly the news of the restoration of Java to the Netherlands resulted in its abandonment. But even after that date, Mackenzie appears to have planned writing something of a more general nature on Java. The publication of Raffles' History of Java in 1817 scotched that idea. ${ }^{59}$

What influence Mackenzie had on Raffles' ideas on the land rent question, especially with regard to the introduction of the Ryotwari settlement, will be discussed later. ${ }^{60}$ For the moment let us consider briefly the work of the Land Tenure Commission as a whole.

Most of the limitations of the Commission stemmed directly from the magnitude of the task entrusted to it. It was a task of staggering proportions, and one which could have been adequately handled only with the resources and complex machinery of a modern colonial government. Since the 1860's and 1870's when the first scientific investigation of land tenures was made in Java, ${ }^{61}$ until the time of Van Vollenhoven and his pupils, ${ }^{62}$ the great difficulties besetting any investigation into Javanese Adatrecht have come to be realized. Yet the herculean task of investigating the land tenures of Java in 1812-13 was entrusted to four men, who were not only given little assistance in the way of writers and translators to facilitate their work, but were constantly interrupted in their investigations by Raffles' continual demands for one thing or another. In British India, the authorities had learned from sad experience that such an investigation was full of pitfalls, and required much time and diligence to effect. Minto had warned Raffles against precipitous reform before a thorough investigation of the land tenures of the island had been made. But while Raffles fostered the notion that careful investigations were going on, and did not rush blindly into reform, he appears to have done very little to assist the labours of the Mackenzie Commission.

The most formidable obstacle which the Commissioners faced was the difficulty of language. With the exception of Rothenbühler none of them spoke Javanese, and so direct questioning of the people

\footnotetext{
See De Haan, F., "Personalia", 604.

See pp. 149-50.

Eindresumé, 3 vols., (1876-96).

(i2 Vollenhoven, C. van, Het Adatrecht van Nederlandsch-Indië, 3 vols. See Haar, B. ter, Adat Law in Indonesia, (1948), Chapter XV, "Adat Law Literature", pp. 234 et seq.
} 
was impossible. Mackenzie himself was well aware of the difficulty. He wrote in his report of August $1812:^{0^{3}}$

The forms established from long custom in these countries I found... precluded such immediate information as would have been desirable to myself, in the progress of a journey which could not be conveniently delayed $\&$ seldom admitted of more than one day at any Regency. As the utmost submission, awe $\&$ deference in speaking or replying is observed by the natives to the Tomagongs, Regents \& Addi Patties, \& the same profound respect is observed even to the inferior officers in their several gradations, whatever questions were necessary on the subject of cultivation or indeed of any other, however trivial, was necessarily addressed thro' the chief \& thro' him put round till it came to the proper person, perhaps the lowest cultivator, the answer coming in the same circuitous mode 86 with all the inconvenience of rendering thro' three different languages, Javanese, Malay \& Dutch into English, it may be imagined with how little effect any Enquiry could be managed in this way, $\&$ that much of the spirit $\&$ energy of the original communication must be lost.

Mackenzie had had trouble in securing information from the Regents at Batavia and Tjirebon. When he complained of this to Knops, who had himself overcome many difficulties by dint of hard work, the latter warned him not to place too much reliance upon the evidence of the Regents in any case. ${ }^{i+4}$ It was wonderful, he wrote, how the accounts of the Regents differed from actual fact. In Boyolali he had found 400 jungs of sawahs and some hundreds of jungs of gagas more than were in the lists given to him by the Regents. „Judge then by that", he told Mackenzie, "on the lists that the Regents give you." ${ }^{55}$ Knops complained that he was always working against those "who do not wish to understand you." much of the information that the Regents supplied had to be accepted, otherwise the Commission would have had to continue its investigations for years.

Another difficulty which hindered the work of the Mackenzie Commission, and one which explains why the meetings were finally abandoned, was the insufficient knowledge of English possessed by

03 "Report of the President....", op. cit.

64 Knops to Mackenzie, November 2, 1812, Mack. Coll., (Pr.), Vol. 74, No. 50.

(65 Same to same, November 9, 1812, Ibid., No. 52.

(6) Loc. cit. 
the Dutch members. Communication between the Commissioners, especially by way of the President, was cumbersome as everything had to be translated. ${ }^{67}$

There was also the difficulty of transport. So long as the Commissioners journeyed through the coastal Regencies reasonable progress was possible. But in the hinterland, the tracks were difficult, and impassable in the wet season. Thus there was a tendency to confine investigations to the desas and the kampongs which were easily accessible.

Despite all these difficulties one cannot help being impressed by the activities of the Commissioners. Although their findings on land tenures were often astray, they produced a mass of useful information on the conditions in Java at the time.

67 In order to overcome the difficulty, Mackenzie invited Christiani to attend the meetings of the Commission, because he had a good command of English. But the need of Javanese, and English-Dutch translators was never satisfied. In despair, Mackenzie used his own private Dutch translator J. Caspertz for the Commission's work, and his English-French-Dutch translator, Lucius Rawdon Burke. Mackenzie to Blagrave, June 10, 1812, "Letter Book [of the] Commission", op. cit., Letter No. 12. 


\section{CHAPTER VII}

\section{THE VILLAGE LAND RENT SETTLEMENTS OF 1813}

While Raffles had promptly informed the Directors of the proposed introduction of the land rent system throughout Java, ${ }^{1}$ he did not report his intentions to Minto until July 11. He forwarded the documents relating to the settlement then being introduced into Pekalongan, together with his Minute of June 14. The land rent system, he told his patron with some exaggeration, was "in a state of progress and gradual advancement through[out] the country".' Raffles did not, in fact, begin the introduction of the system into the coastal districts of Java until a few days later. By a proclamation dated July 19, it was introduced into Tjirebon."

\section{Tjirebon.}

Daendels had attempted to introduce a land revenue system into Tjirebon in $1808 .^{4}$ Under his administration, the districts had been in a state of continual unrest, and the British had inherited a difficult situation there. Following the advice of the Dutch Resident, Raffles had effected a peaceful settlement of Tjirebon in April 1812 by removing some of the obnoxious restraints placed upon the Sultans by Daendels. He excused them from the debts which they had already contracted with the Government, and granted them an annual allowance of 5,000 Rix drs. silver. ${ }^{5}$ In order to remove further grievances, a survey of the padi fields was ordered, so that new regulations could be established for the future deliveries of rice to the Government. ${ }^{6}$ Lawrence was appointed to succeed the Dutchman

1 Raffles to the Secret Committee, June 30, 1813, Java, Vol. 60, Part III.

2 Raffles to Minto, July 11, 1813, Bengal Civil Colonial Consultations, December 18, 1813.

3 The proclamation is recorded in Java Public Consultations, April 21, 1815.

4 Deventer, S. van, L.S., I, pp. 38-44.

5 Java Public Consultations, April 10, 1812.

6 Loc. cit. 
M. Waterloo as Resident in May, ${ }^{7}$ and by a judicious policy won support for the British administration. In the following month, after the apprehension of the notorious bandit Bagus Rangien [?], Raffles predicted "a large contingent or revenue" from Tjirebon. ${ }^{8}$

The contingents and forced deliveries, however, were soon to cease. After a "course of confidential communications" ${ }^{\theta}$ with the new Resident of Tjirebon, Major W. Raban, early in July 1813, Raffles deemed that the time was opportune for the introduction of the land rent system. He set out for Tjirebon, and with the help of Raban and Crawfurd secured the Sultans' compliance with his wishes. Under the new arrangements they were to be relieved of the payment of contingents, forced deliveries and services, and the Government was to take the collection of the revenue into its own hands. The Sultans were given possession of their private lands, and their salaries of 5,000 Rix drs. were continued. Their ranks and dignities were also to be respected. ${ }^{10}$ On July 19, the following proclamation was issued outlining the intentions of the Government. ${ }^{11}$

The system heretofore existing in Cheribon having been found equally oppressive to the people and ruinous to the resources of the country, it has been resolved to introduce an amended system of administration throughout.

The Capitation Tax is abolished from this date, and all persons are expressly prohibited from levying Contributions or Taxes upon the native inhabitants that are not expressly defined and authorized by the publications of Government.

Instead of the Contingent heretofore required, which has been found to exceed the immediate means of the country, the lands throughout will be administered by Government and let out to the native inhabitants of Cheribon for a fixed rent per annum, calculated according to the produce.

Every facility will be given to agriculture and commerce, and it may be expected that the country of Cheribon will again become rich and happy, when every man is allowed to enjoy in security the fruits of his industry.

7 Raffles to Minto, July 16, 1812, Bengal Civil Colonial Consultations, December 5, 1812.

8 Loc. cit.

* "Extract Proceedings of the Government of Java in the Separate and Revenue Department dated the 20th July, 1813", recorded in Java Public Consultations, April 21, 1815.

10 Loc. cit.

11 Loc. cit. 
Whenever the Government may require the produce of the land for public purposes, or the services of the inhabitants, they will invariably pay for the same at fair and equitable rates, and as soon as the lands are let and the new system generally introduced, all forced deliveries of produce 86 all feudal services will be abolished.

The Sultans of Cheribon convinced of the state to which the country has been reduced under the former system, and of the advantages which it will derive under the new arrangement, require and call upon all the inhabitants of Cheribon to enter fully and cordially into the arrangements now directed, by which the immediate administration of the lands will be taken into the hands of Government.

On taking into the hands of Government the immediate administration of the lands, and the collection of the revenues, according to the actual value and produce, it is declared that all chiefs and persons heretofore deriving a revenue under the former system, and who from their character, rank and services are entitled to consideration, will receive a liberal provision, and they will on no account be injured in their rank or emoluments.

All persons are required to conduct themselves peaceably, and the Tumongongs of the different districts are held responsible for any exactions that may be made from the people, or for any disturbance that may arise.

The Chinese will not be permitted to rent lands, or to interfere in the interior of the country, and the principle of the new arrangement is to secure to the native inhabitants the quiet and happy possession of their property with the peculiar privileges, laws, and usages of the country.

Raban continued in his post as Resident, and together with Crawfurd, the Resident at Yogyakarta, constituted a Commission to let the lands on the following principles: ${ }^{12}$

i. the cultivators to be secured in possession of the lands on condition of paying a rent equivalent to the amount of produce and service they gave previously,

ii. the lands to be let in farms of not less than what might be attached to a village, and not more than 100 jungs, except where compensation to a native chief required more,

iii. an adequate compensation to be made to the native chiefs throughout the Regency,

iv. the lands to be let for money, but payment in kind (rice) to be accepted,

v. the lands to be let for no longer than three years, preferably for one year only.

12 Sub., pp. 26-7. 
Less than a month after he had made these arrangements, Raffles informed Minto that he was about to proceed to the Eastern Districts to introduce the land rent system there. ${ }^{13} \mathrm{He}$ left Batavia on August 26, and on his journey through Tjirebon found the Sultans and people "perfectly satisfied and contented with the arrangements made". ${ }^{14}$ The compensation actually paid to the Sultans and chiefs in money and lands during the first settlement of the land rent of Tjirebon, was as follows: ${ }^{15}$

\begin{tabular}{|l|c|c|c|c|c|c|c|}
\hline \multicolumn{1}{|c|}{ Chiefs } & $\begin{array}{c}\text { Quantity } \\
\text { of } \\
\text { sawahs }\end{array}$ & $\begin{array}{c}\text { Assessed value } \\
\text { of Lands per } \\
\text { annum }\end{array}$ & $\begin{array}{c}\text { Money } \\
\text { Grants }\end{array}$ & $\begin{array}{c}\text { Total value of } \\
\text { Land \& Money } \\
\text { Grants }\end{array}$ \\
\hline Jungs & J. Rs. & Sts. & J. Rs. & Sts. & J. Rs. & Sts. \\
\hline Sultan Sepuh & 400 & 4,155 & 24 & 8,000 & - & 12,155 & 24 \\
\hline Sultan Anom & 400 & 6,426 & 6 & 8,000 & - & 14,426 & 6 \\
\hline \begin{tabular}{l} 
Sultan Tjirebon \\
\hline $\begin{array}{l}\text { Pangeran Raja } \\
\text { Kertaningrat }\end{array}$
\end{tabular} & 128 & 1,597 & 6 & 8,000 & - & 9,597 & 6 \\
\hline $\begin{array}{l}\text { Tumengsung of } \\
\text { Bengawan }\end{array}$ & $121 / 2$ & 132 & - & - & - & 132 & - \\
\hline $\begin{array}{l}\text { Demang of the } \\
\text { Blandongs }\end{array}$ & 35 & 770 & - & 2,112 & - & 2,882 & - \\
\hline $\begin{array}{l}\text { Tumengsung of } \\
\text { Radjagaluh }\end{array}$ & 35 & 1,102 & 6 & 660 & - & 1,762 & 6 \\
\hline $\begin{array}{l}\text { Tumeng8ung of } \\
\text { Sindangkasih }\end{array}$ & 35 & 1,128 & 18 & 712 & 24 & 1,841 & 12 \\
\hline $\begin{array}{l}\text { Tumeng8ung of } \\
\text { Pandjalu }\end{array}$ & 35 & 565 & 12 & 369 & 18 & 935 & -6 \\
\hline
\end{tabular}

13 Raffles to Minto, August 24, 1813, Bengal Civil Colonial Consultations, December 11, 1813.

14 Minute by Raffles, September 17, 1813, Java Public Consultations, September 17, 1813. The Minute has been published by Deventer, M. L. van, $N . G .$, pp. $18-24$, but with some inaccuracies.

15 Report on Tjirebon by Bauer and Addison, July 14, 1814, Raffles Collection, V, No. 4 (i). 


\begin{tabular}{|c|c|c|c|c|c|c|c|}
\hline \multirow[t]{2}{*}{ Chiefs } & \multirow{2}{*}{$\begin{array}{c}\begin{array}{c}\text { Quantity } \\
\text { of } \\
\text { sawahs }\end{array} \\
\text { Jungs }\end{array}$} & \multicolumn{2}{|c|}{$\begin{array}{l}\text { Assessed value } \\
\text { of Lands per } \\
\text { annum }\end{array}$} & \multicolumn{2}{|c|}{$\begin{array}{l}\text { Money } \\
\text { Grants }\end{array}$} & \multicolumn{2}{|c|}{$\begin{array}{l}\text { Total value of } \\
\text { Land \& Money } \\
\text { Grants }\end{array}$} \\
\hline & & J. Rs. & Sts. & J. Rs. & Sts. & J. Rs. & Sts. \\
\hline $\begin{array}{l}\text { Tumengsung of } \\
\text { Telaga }\end{array}$ & 35 & 680 & 14 & 660 & - & 1,340 & 14 \\
\hline $\begin{array}{l}\text { Pangeran of } \\
\text { Tjiamis }\end{array}$ & 15 & 256 & 15 & 264 & - & 520 & 15 \\
\hline $\begin{array}{l}\text { Tumengsung of } \\
\text { Kuningan }\end{array}$ & 35 & 499 & 12 & 1,267 & 6 & 1,766 & 18 \\
\hline $\begin{array}{l}\text { Tumengsung of } \\
\text { Tjikaso [?] }\end{array}$ & 35 & 805 & 6 & 1,003 & 6 & 1,808 & 12 \\
\hline $\begin{array}{l}\text { Tumeng8ung of } \\
\text { Linggadjati }\end{array}$ & 35 & 752 & 12 & 660 & - & 1,412 & 12 \\
\hline $\begin{array}{l}\text { Tumenssung of } \\
\text { Losari \& Gebang }\end{array}$ & 35 & 308 & - & 660 & - & 968 & - \\
\hline $\begin{array}{l}\text { Tumengsung of } \\
\text { Tjirebon }\end{array}$ & 35 & 382 & 24 & 660 & - & 1,042 & 24 \\
\hline TOTAL & $1,3061 / 2$ & 19,608 & 11 & 33,292 & 24 & 52,901 & 5 \\
\hline
\end{tabular}

Tegal, Brebes and Pemalang.

At Tegal, Raffles charged the Resident, Major J. P. Keasberry, who had some knowledge of native customs, ${ }^{16}$ to introduce the land rent system into the Regency, and also into Brebes and Pemalang. ${ }^{17}$ Keasberry's instructions were similar to those issued to Crawfurd, ${ }^{18}$ and specified a yearly village settlement. The Regents of Tegal, Brebes and Pemalang were granted salaries, as compensation for former emoluments sacrificed through the introduction of the new system. ${ }^{19}$ In addition, lands were granted to them and to the lesser chiefs as follows: ${ }^{20}$

16 De Haan, F., "Personalia", 590.

17 Deventer, M. L. van, N.G., 23.

18 Sub., pp. 26-7.

14 Deventer, M. L. van, N.G., 22.

20) Report on Tegal by Bauer and Addison, July 16, 1814, Raffles Collection, V, No. 4 (ii). 


\begin{tabular}{|c|c|c|c|c|c|c|c|}
\hline \multirow[t]{2}{*}{ Chiefs } & \multirow{2}{*}{$\begin{array}{c}\begin{array}{c}\text { Quantity } \\
\text { of } \\
\text { sawahs }\end{array} \\
\text { Jungs }\end{array}$} & \multicolumn{2}{|c|}{$\begin{array}{l}\text { Assessed value } \\
\text { of Lands per } \\
\text { annum }\end{array}$} & \multicolumn{2}{|c|}{$\begin{array}{l}\text { Money } \\
\text { Grants }\end{array}$} & \multicolumn{2}{|c|}{$\begin{array}{c}\text { Total value of } \\
\text { Land \& Money } \\
\text { Grants }\end{array}$} \\
\hline & & J. Rs. & Sts. & J. Rs. & Sts. & J. Rs. & Sts. \\
\hline Regent of Tegal & 250 & \multirow[b]{2}{*}{10,337} & \multirow[b]{2}{*}{24} & \multirow[b]{2}{*}{7,920} & \multirow[b]{2}{*}{ - } & \multirow[b]{2}{*}{18,257} & \multirow[b]{2}{*}{24} \\
\hline $\begin{array}{l}\text { Ex-Regent of } \\
\text { Tegal }\end{array}$ & 25 & & & & & & \\
\hline Patih of Tegal & $331 / 2$ & 1,205 & 18 & - & - & 1,205 & 18 \\
\hline Djaksa of Tegal & 30 & 1,302 & 12 & 一 & - & 1,302 & 12 \\
\hline "Priest" of Tegal & $241 / 2$ & 1,080 & 6 & - & 一 & 1,080 & 6 \\
\hline Regent of Brebes & 175 & \multirow[b]{2}{*}{4,461} & \multirow[b]{2}{*}{18} & \multirow[b]{2}{*}{5,280} & \multirow[b]{2}{*}{ 一 } & \multirow[b]{2}{*}{9,741} & \multirow[b]{2}{*}{18} \\
\hline $\begin{array}{l}\text { Ex-Regent of } \\
\text { Brebes }\end{array}$ & 8 & & & & & & \\
\hline Patih of Brebes & $331 / 2$ & 732 & 18 & 一 & - & 732 & 18 \\
\hline "Priest" of Brebes & $241 / 2$ & 554 & 12 & 一 & - & 554 & 12 \\
\hline $\begin{array}{l}\text { Regent of } \\
\text { Pemalang }\end{array}$ & 150 & 4,243 & 24 & 4,620 & - & 8,863 & 24 \\
\hline Patih of Pemalang & $331 / 2$ & 1,245 & 6 & - & - & 1,245 & 6 \\
\hline $\begin{array}{l}\text { "Priest" of } \\
\text { Pemalang }\end{array}$ & $241 / 2$ & 433 & 12 & - & - & 433 & 12 \\
\hline TOTAL & 812 & 25,597 & - & 17,820 & 一 & 43,417 & 一 \\
\hline
\end{tabular}

Semarang, Kendal and Demak.

Lieutenant-Colonel J. Eales, who took charge of the Residency of Semarang on September 1, 1813, had been given authority by Raffles to introduce the land rent system into Semarang, Kendal, Demak, Djapara, Djuwana, Pati and Kudus. ${ }^{21}$ His instructions, however, merely referred to Semarang. ${ }^{22}$ An annual settlement similar to those ordered for Tjirebon and Tegal was recommended. The leases were to be granted to the village headmen at a rental reckoned at about two-fifths of the gross annual produce of rice.

21 Deventer, M. L. van, N.G., 23.

22 Raffles to Eales, August 31, 1813, Bengal Civil Colonial Consultations, January 15, 1814. 
When the land rent was introduced, all internal taxes, contributions and forced services were to be abolished. The first yearly settlement, Eales was told, was only preparatory to a permanent assessment that would be made later. Compensation to the Regents and other chiefs was to be granted in money and lands as follows: ${ }^{23}$

\begin{tabular}{|c|c|c|c|c|c|}
\hline \multirow[t]{2}{*}{ Chiefs } & \multirow{2}{*}{$\begin{array}{c}\begin{array}{c}\text { Quantity } \\
\text { of } \\
\text { sawahs }\end{array} \\
\text { Jungs }\end{array}$} & \multicolumn{2}{|c|}{$\begin{array}{c}\text { Assessed value } \\
\text { of Lands per } \\
\text { annum }\end{array}$} & \multicolumn{2}{|c|}{$\begin{array}{l}\text { Money } \\
\text { Grants }\end{array}$} \\
\hline & & J. Rs. & Sts. & J. Rs. & Sts. \\
\hline Regent of Semarang & 300 & - & - & 11,000 & - \\
\hline Patih of Semarang & 15 & - & 一 & 一 & - \\
\hline Djaksa of Semarang & \multicolumn{5}{|c|}{ in proportion to his present income } \\
\hline Pangulu of 'Semarang & 40 & - & - & - & - \\
\hline $\begin{array}{l}\text { Brother-in-Law of the } \\
\text { Regent of Semarang }\end{array}$ & 40 & \multicolumn{4}{|c|}{ (half uncultivated) } \\
\hline Regent of Kendal \& Kaliwungu & 200 & - & 一 & 5,500 & - \\
\hline Patih of Kendal & 10 & - & 一 & - & - \\
\hline Patih of Kaliwungu & 10 & - & - & - & - \\
\hline Family of Regent of Kendal & 20 & - & - & - & - \\
\hline "Priests" of Kendal & 15 & 一 & - & - & - \\
\hline "Priests" of Kaliwungu & 10 & - & 一 & - & - \\
\hline Regent of Demak & 200 & - & - & 5,500 & 一 \\
\hline Patih of Demak & 10 & - & 一 & 一 & 一 \\
\hline Family of Regent of Demak & 20 & - & 一 & - & - \\
\hline Ex-Regent of Demak & 200 & \multicolumn{4}{|c|}{ (half uncultivated) } \\
\hline Ex-(Second)Regent of Demak & 60 & \multicolumn{4}{|c|}{ (half uncultivated) } \\
\hline $\begin{array}{l}\text { Family of Ex-(Second)Regent } \\
\text { of Demak }\end{array}$ & 20 & \multicolumn{4}{|c|}{ (half uncultivated) } \\
\hline Mosque of Demak & 40 & - & - & 一 & $i-$ \\
\hline
\end{tabular}

23 A list of the lands and salaries actually paid to the Regents etc. of Semarang, 
Raffles instructed Eales to collect any outstanding amounts of contingents and recognition money. However, as it would be difficult arranging about arrears for 1813 , one-half of the contingents and recognition money was to be collected, and the land rent system introduced immediately. Eales was authorized to purchase rice for the Government at a price which would encourage the Javanese to sell it. As the coffee and pepper gardens were to be no longer subject to forced deliveries, he was instructed to rent them out in common with the other lands. Raffles wrote: ${ }^{24}$

It has been estimated by the Regent of Tegal that the rent which Coffee lands are capable of yielding, may, generally speaking, be estimated at the rate of 1 Spanish Dollar per 1,000 trees, on condition that Government will ensure a market at the rate of 3 Spanish Dollars for 125 Dutch lbs., leaving the cultivators ... at liberty to dispose of the Coffee at any better market which may offer, and without paying duty on exportation.

The coffee gardens best suited for sawah, however, were to be let as waste lands with an exemption of rent for three years, while the pepper gardens were to be let as they stood. The Government agreed to purchase pepper at the old rate of $3 \mathrm{Sp}$. drs. a pikul of 125 Dutch lbs.

Raffles exhorted Eales to be judicious in introducing the new system, and not to hesitate to apply to the Government in case of any difficulty. He was to keep a regular register of the lands as they were rented out, "numbering and describing each Farm, according to its population, produce, and situation". ${ }^{25} \mathrm{He}$ was to master every detail of the internal administration of the districts entrusted to him. Pemberton, who had had experience of the land rent system in Djipang, was appointed his assistant. ${ }^{20}$

\section{Djapara, Djuwana, Pati and Kudus.}

The work of introducing the land rent system into these districts apparently proved too arduous a task for Eales, for in October Raffles asked McQuoid to assist him with the assessment of Djapara,

Kendal and Demak does not exist in European sources. I have followed the lists in Raffles' Minute of September 17, 1813, Deventer, M. L. van, N.G.. pp. 20-2, and in Eales' instructions, Ibid.

24 Raffles to Eales, August 31, 1813, op. cit.

25 Loc. cit.

26 De Haan, F., "Personalia", pp. 541; 625. 
Djuwana and its dependent districts. ${ }^{27}$ The following compensation in money and lands was ordered to be paid to the Regents and other native chiefs.

\begin{tabular}{|c|c|c|c|c|c|}
\hline \multirow[t]{2}{*}{ Chiefs } & \multirow{2}{*}{$\begin{array}{c}\begin{array}{c}\text { Quantity } \\
\text { of } \\
\text { sawahs }\end{array} \\
\text { Jungs }\end{array}$} & \multicolumn{2}{|c|}{$\begin{array}{l}\text { Assessed value } \\
\text { of Lands per } \\
\text { annum }\end{array}$} & \multicolumn{2}{|c|}{$\begin{array}{l}\text { Money } \\
\text { Grants }\end{array}$} \\
\hline & & J.Rs. & Sts. & J. Rs. & Sts. \\
\hline Regent of Djapara & 400 & - & 一 & 8,800 & - \\
\hline Ex-Regent of Djapara & 40 & (half unc & Itivate & & \\
\hline $\begin{array}{l}\text { The tombs of the Regent's } \\
\text { ancestors to be secured to his } \\
\text { family, together with }\end{array}$ & 100 & - & - & - & - \\
\hline Regent of Djuwana & 150 & - & - & 4,400 & - \\
\hline $\begin{array}{l}\text { The tombs of the Regent's } \\
\text { ancestors to be secured to his } \\
\text { family }\end{array}$ & - & - & - & - & - \\
\hline Regent of Pati & 300 & - & - & 8,800 & - \\
\hline $\begin{array}{l}\text { The tombs of the Regent's } \\
\text { ancestors to be secured to his } \\
\text { family }\end{array}$ & - & 一 & - & 一 & 一 \\
\hline Regent of Kudus & 200 & - & - & 6,600 & 一 \\
\hline $\begin{array}{l}\text { The tombs of the Regent's } \\
\text { ancestors to be secured to his } \\
\text { family }\end{array}$ & - & - & - & - & 一 \\
\hline
\end{tabular}

The form of contract issued by Raffles for the first land rent settlements in the Eastern Districts was as follows: ${ }^{28}$

The Nawala of the British Government is hereby entrusted to ... the Village of ... to confer upon him the lease of the lands of the said Village, consisting of ... Jongs of Sawah, ... Jongs Tipar or Tagal, and... Jongs of Coffee Lands for the

27 Ibid., 606.

28 The idea of issuing the contract in the form of a Nawolo (see Deventer, S. van, L.S., I, 190, footnote + ) was probably suggested to Raffles by Crawfurd, who had forwarded to him copies of original Nawolos granted by the Sultan. The copy of the above contract is taken from Bengal Civil Colonial Consultations, January 15, 1814. 
period of one year, commencing in Malaut last, and ending in Malaut ensuing, subject to the terms and conditions therein specified, that is to say, the said... shall pay to the British Government for the rent of the said lands the annual sum ... of Spanish Dollars, payable in two half yearly instalments, viz. at the festival of Oumosa... Spanish Dollars, and at the festival of Malaut... Spanish Dollars, one third in silver and two thirds in copper money (at the current rate of the day with silver). The said ... engages that he will secure the Cultivators of the Village, who are possessed of lands, in the full enjoyment of their property, according to the customs of the Country, and in obedience to such regulations as the British Government may be pleased to enact for their future security, that he will not interfere in the collection of the Zakat, nor receive any part thereof for his own benefit, and that he will henceforward desist from levying a Capitation Tax, or any species of contribution whatever. Moreover, he hereby promises to discharge zealously, and faithfully, the duties of Police which he will be instructed to perform under the new arrangement. In failure of one or any of these stipulations, he shall be considered to have forfeited the benefits of the present Lease. The British Government on its side, and in consideration of the rent herein stipulated, hereby exonerate and discharge the said ... and the Inhabitants of the Village of ... from the further payments of the Gantang, Capitation Tax, working in the Coffee Gardens..., and all gratuitous services whatever (except the repair of Roads and Bridges) leaving one and all of them free to follow their own pursuits at pleasure, and engaging that should their personal services and produce be at any time indispensibly necessary, the same will not be required without the payment of a liberal equivalent, at least to the ordinary, and market rate of produce and labour.

Done at...

this day of ...

Javanese year.

Surabaya, Gresik, Sidayu, Lamongan, Bangil and Pasuruan.

By a similar set of instructions to those issued to Eales, LieutenantColonel A. Adams was authorized on September 5 to introduce the land rent system into the above districts. ${ }^{29}$ Two days later, however, Raffles appointed H. G. Jourdan to the post of Resident of Pasuruan with orders to assist Adams with the land rent settle-

De Haan, F., "Personalia", 484. The official appointment dated from September 17. 
ment there. ${ }^{30}$ Jourdan, as we have seen, had already gained experience in revenue affairs in Djapan and Wirasaba. These two districts were now incorporated in the Residency of Surabaya.

After conferring with the Regents and chiefs, Raffles gave orders for compensation to be paid to them proportionate to the losses which they were expected to suffer under the new system. During the first settlement the amounts actually granted to them are on page $138 .^{31}$

\section{Besuki, Probolinggo, Panarukan, Puger and Banjuwangi.}

Early in 1812, Raffles had recognized Daendels' sales of the Probolinggo-Besuki lands. He had done so against the advice of Goldbach and other Dutchmen, who had warned him that the oppressions of the Chinese proprietors would cause trouble in that part of the island. This was soon to prove true. In May 1813, more than 2,000 people in Probolinggo gave their support to a religious fanatic from Ampel, who had declared that his mission was to introduce Mohammedanism throughout the Oosthoek, and to take charge of Probolinggo. ${ }^{32}$ The rebels were finally defeated by a small British force, but not before they had burned and plundered many Chinese properties and killed the proprietor Han Kiko. The two British military officers at Probolinggo agreed that the cause of the disturbances was basically the oppression of the Chinese proprietors. ${ }^{33}$

When he heard of the rebellion, Raffles immediately despatched Crawfurd to the Oosthoek to investigate the causes of the revolt. ${ }^{34}$ Crawfurd arrived at Probolinggo on June 3. On the following day he wrote to Raffles: ${ }^{35}$ September 6, 1814, Raffles Collection, V, No. 4 (xi), with the exception of those for Surabaya, Bangil and Pasuruan. In the case of the latter districts, I have used the estimates made by Raffles in his Minute of September 17, 1813, Deventer, M. L. van, N.G., pp. 20-2.

32 The best account of the actual rising was given by Vos, the Bailieu of Probolinggo, Java Military Consultations, June 7, 1813. See also Java Government Gazette, June 5, 1813; June 12, 1813.

March 19, 1814.

Crawfurd to Raffles, June 4, 1813, Ibid. 


\begin{tabular}{|c|c|c|c|c|c|c|c|}
\hline \multirow[t]{2}{*}{ Chiefs } & \multirow{2}{*}{$\mid \begin{array}{c}\begin{array}{c}\text { Quantity } \\
\text { of } \\
\text { sawahs }\end{array} \\
\text { Jungs }\end{array}$} & \multicolumn{2}{|c|}{$\begin{array}{c}\text { Assessed value } \\
\text { of Lands per } \\
\text { annum }\end{array}$} & \multicolumn{2}{|c|}{$\begin{array}{l}\text { Money } \\
\text { Grants }\end{array}$} & \multicolumn{2}{|c|}{$\begin{array}{c}\text { Total value of } \\
\text { Land \& Money } \\
\text { Grants }\end{array}$} \\
\hline & & J. Rs. & Sts. & J. Rs. & Sts. & J. Rs. & Sts. \\
\hline Bupati of Gresik & $400 \%$ & 8,000 & - & 11,000 & - & 19,000 & - \\
\hline Patih of Gresik & $201 / 2$ & 410 & - & - & - & 410 & 一 \\
\hline Patih of Gresik & 16 & 320 & - & - & - & 320 & - \\
\hline Djaksa of Gresik & $47 / 8$ & 97 & 15 & - & - & 97 & 15 \\
\hline Pangulu of Gresik & 2 & 40 & - & - & - & 40 & 一 \\
\hline Bupati of Sidayu & 150 & 7,500 & 一 & 8,800 & - & 16,300 & 一 \\
\hline Patih of Sidayu & 22 & 960 & 一 & - & - & 960 & 一 \\
\hline Pangulu of Sidayu & 2 & 40 & - & - & - & 40 & - \\
\hline $\begin{array}{l}\text { Bupati of } \\
\text { Lamongan }\end{array}$ & 400 & 8,000 & - & 8,800 & - & 16,800 & - \\
\hline Patih of Lamongan & 16 & 320 & - & - & - & 320 & - \\
\hline $\begin{array}{l}\text { Djaksa of } \\
\quad \text { Lamongan }\end{array}$ & $21 / 2$ & 50 & - & - & 一 & 50 & - \\
\hline $\begin{array}{l}\text { Pangulu of } \\
\text { Lamongan }\end{array}$ & 2 & 40 & - & - & - & 40 & - \\
\hline $\begin{array}{l}\text { Sahid Ali Jafir } \\
\text { (Pension for } \\
\text { services) }\end{array}$ & $98 \%$ & 2,000 & - & - & - & 2,000 & - \\
\hline Regent of Surabaya & 200 & - & - & 15,400 & 一 & - & - \\
\hline Patih of Surabaya & 25 & - & - & 一 & 一 & - & - \\
\hline D jaksa of Surabaya & 5 & - & - & - & - & 一 & - \\
\hline Regent of Bangil & $\begin{array}{c}\text { adequate } \\
\text { to yield } \\
\mathbf{4 , 4 0 0} \\
\text { J.Rs. p.a. }\end{array}$ & - & - & 6,600 & - & - & - \\
\hline $\begin{array}{l}\text { Regent of } \\
\text { Pasuruan }\end{array}$ & $\begin{array}{c}\text { adequate } \\
\text { to yield } \\
4,400 \\
\text { J.Rs. p.a. }\end{array}$ & - & - & 6,600 & - & 一 & - \\
\hline
\end{tabular}


The cry against the oppression and maladministration of the Chinese proprietors is ... so loud and so uniform, that it seems beyond the reach of doubt [that] the late insurrection has had its origin in the discontent which these oppressions have produced. The interests of religion on this, as on many former occasions, were made a rallying point.

He said it was a monstrous prerogative for the Chinese to have had the right of levying taxes on the people. This right had been abused, not so much by the landholder himself - "a man of respectable character" - but by his Chinese retainers, who had treated the people harshly. An excessive capitrtion tax, and rent for the use of the ground, had been levied, and produce had been purchased from the peasants at arbitrary rates. Crawfurd said that he would make liberal use of the powers entrusted to him to effect a settlement on "the general principles of an improved administration" which he knew Raffles intended to introduce throughout the island. ${ }^{36}$ Crawfurd's reference was to the land rent system.

No sooner had the disturbances in Probolinggo been settled, than Han Tjan Pit, the Chinese landholder of Besuki and Panarukan, declared that he could no longer meet the purchase instalments for his estate. He petitioned the Government to resume his lands. ${ }^{37}$ This offer was readily seized upon by Raffles, and on June 13 he issued fresh instructions to Crawfurd to negociate for the repurchase of the whole of the Chinese estates in the Oosthoek. ${ }^{38}$ However, Raffles cautioned him about his intention of introducing the land rent system into the districts. It was "premature", Raffles wrote, ${ }^{39}$ "to commence on any settlement or any establishment of a land revenue on account of Government" at that moment. Shortly afterwards, Crawfurd came to a hasty agreement with Han Tjan Pit for the repurchase of his estates, and handed over the charge of the districts to Lieutenant W. Cotes.

Crawfurd left precise instructions for Cotes' guidance..$^{40} \mathrm{He}$ was to continue collecting the rents from the estates as the Chinese had done, except that the capitation tax was to be abolished. Cotes was to receive the principal part of the rents in kind, as formerly, at the

38

38

40

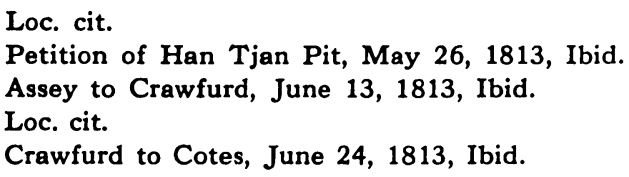


general rate of 10 hamats [amet's] per jung. This was to be received "from the Patingi of each village without entering into any detail with the Individual Cultivator". ${ }^{41}$ Crawfurd thought the above rate might prove to be too high in some cases, and too low in others. He suggested, therefore, that Cotes should begin an investigation of the lands, and prepare statistical tables detailing the rents of each village. Crawfurd continued: ${ }^{42}$

The Demangs may, if you find it convenient, be made answerable for the collection of the grain in their respective districts, or the whole produce, if practicable, may be brought into the stores at Probolingo.

In any case, grain was to be sold by public auction, or occasionally to wholesale merchants for export. Every possible care was to be exercised to keep the sale as near as possible to the market prices, so that the cultivators would not be affected. On no occasion was Cotes to hoard rice in the hope of selling it at a higher price later. In order to give every facility for the collection of the rent in kind, Crawfurd ordered that all export duties at Probolinggo were to be removed from July 1. But as the great proportion of the padi of Besuki and Panarukan had already been collected by the Chinese proprietor for 1813 , it would be advisable to allow him to finish the collection for the year. Otherwise the collection would become confused. Crawfurd continued: ${ }^{43}$

Although it becomes indispensably requisite that the rent of the sawahs should be paid in kind, that principle must be dispensed with as far as concerns the whole produce of the tagal, the variety of which would render any interference in its details extremely troublesome, if not impracticable.

The Grabang ${ }^{44}$ having been remitted, it will not prove in any respect burthensome to the people to require a money rent for the tagal. The amount of this may generally be calculated at 12 Spanish Dollars per jung. That sum must be received from the Patingis, but like the amount of rent demanded in kind from the sawahs, there will be a necessity for adapting the rent to the circumstances of the land, and, therefore, you will find it necessary to open a column for a money rent for the tagals apposite to each village, and decide upon the amount

41 Loc. cit.

42 Loc. cit.

43 Loc. cit.

44 Capitation tax. 
to be assessed in some respects by the report you may receive of the quality of the soil, but chiefly by the nature of the crops which such lands now yield.

The marriage tax was to be abolished, but a fee was to be charged on each marriage to constitute a fund for the maintenance of the Pangulus and Djaksas of the district. ${ }^{45}$ In a private letter, Crawfurd informed Cotes that he thought it would be advisable to give the people the option of paying rents either in money or kind. ${ }^{46}$

On July 13, the members of the Java Council agreed with Raffles that the Chinese estates should be resumed by the Government, but postponed consideration of the means of financing the purchase. ${ }^{47}$ Early in the following month, Raffles instructed David Hopkins "to arrange and carry into effect the agreement entered into by $\mathrm{Mr}$. Crawfurd with the landholder of Bysookie and Panarookan, and also to adjust the amount to be refunded to the family of the late proprietor of Probolingo".48 Hopkins was also appointed one of the Commissioners for introducing the land rent into the Eastern Districts, and told to effect such a settlement in the former Chinese districts of the Oosthoek. ${ }^{49}$

In September, Hopkins concluded an agreement with Han Tjan Pit for the repurchase of Besuki and Panarukan, by which he was to receive $400,000 \mathrm{Sp}$. drs. at an interest of $6 \%$. The first instalment was to be paid on September 15, 1814. In addition, he was to be granted monetary compensation for the improvements made on his estate, and given a quantity of rentfree land at Surabaya for his maintenance during his lifetime. ${ }^{50}$ Hopkins also came to an arrangement for the repurchase of Probolinggo with the family of the late Chinese proprietor. Hopkins advised Raffles to grant pensions of $50 \mathrm{Sp}$. drs. to each of the late landholder's six children so long as they lived, and an allowance when they married. The Government should also purchase a sugar mill at Pasuruan with 30 jungs of land for their upkeep, and should

45 Crawfurd to Cotes, June 24, 1813, op. cit.

46 Same to same, June 24, 1813, Bengal Civil Colonial Consultations, March 19, 1814.

47 Java Public Consultations, July 13, 1813.

48 Assey to Hopkins, August 8, 1813, Java Separate Department Proceedings, August 9, 1813; De Haan, F., "Personalia", 581.

48 Loc. cit.

50 Hopkins to Raffles, September 12, 1813, Java Public Consultations, September 28, 1813. 
pay off all the debts incurred by the late proprietor. Altogether, Hopkins estimated that the Government would have to pay 93,974 Sp. drs. for the repurchase of the Probolinggo estate. ${ }^{51}$ These terms were agreed to by Raffles on November $16,{ }^{52}$ and the British Government immediately took full control of the districts.

In the meantime, Hopkins had turned his attention to the introduction of the land rent system into the districts east of Bangil. As Jourdan had been told to introduce the new system into Pasuruan, Hopkins' instructions clashed with Raffles' previous orders. ${ }^{53}$ Hopkins' instructions were issued early in September, ${ }^{54}$ and charged him with the introduction of a more detailed settlement of the land rent in the former Chinese districts than had been ordered elsewhere. Raffles wrote: ${ }^{55}$

It has not been deemed advisable on the first introduction of these arrangements, to enter generally into such a detailed system of management, as would include an immediate consideration of the rights and interests of each individual cultivator; and in the instructions given in the other districts, it has been directed that the lands be, in the first instance, rented to the chief local authority in each village or community, whether recognized under the designation of Petingi, Bakal, Lurah, or other title. But as the state of society and cultivation, in the districts lately held by the Chinese, may admit of an exception, and a more detailed settlement than elsewhere, you are authorized to introduce the same, to such an extent as may appear safe and practicable, with a due attention to the prejudices of the people and the tranquillity of the country.

The heads of villages or communities being thus considered, leases are to be granted in the Javanese language.

In fixing the amount of rent, you will ascertain, as far as practicable, the extent of all existing burthens, imposts, and services whatever, and endeavour to determine the amount these have hitherto borne to the produce of the soil; which amount, after an equitable and liberal allowance for any oppression hitherto felt, is to form the basis of the rental, to be demanded as the dues of Government.

51 Same to same, September 19, 1813, Java Public Consultations, November 24, 1813.

52 Robinson to Hopkins, November 16, 1813, Ibid.

53 De Haan, F., "Personalia", 581. Hopkins' instructions clearly referred to Pasuruan, (Sub., 30) but in his Minute of September 17, 1813, (Deventer, M. L. van, N.G., 23) Pasuruan was placed under Adams' jurisdiction.

51 Sub., pp. $28-32$.

55 Ibid., 29. 
Compensation to the Regent of Pasuruan was mentioned, ${ }^{56}$ but this Regency was soon removed from Hopkins' charge. The grants of money and lands to the Regents of Puger, Probolinggo and Banjuwangi were to be regulated later according to their existing emoluments. $^{57}$

Raffles reports on the introduction of the land rent system throughout Java.

After personally issuing to the various European officers the instructions for the settlement of the land rent, and conferring with the Regents about the amounts of compensation which were to be paid to them, Raffles returned to Batavia in the middle of September. On the 17th, he presented a Minute on the subject to the Council in which he outlined the arrangements made in the Eastern Districts, ${ }^{58}$ and four days later he informed the Directors of the introduction of the new system of revenue throughout the island. $\mathrm{He}$ said it had already been effected in Tjirebon, Pekalongan, Kedu and the other Transferred Districts, and was "in progress" throughout the remainder of the Company's domains, except in the Batavian and Preanger Regencies. Raffles explained that as a part of the new system, the export duties on colonial produce were to be removed, and that he was contemplating the abolition of the tollgates. The loss of these farms, he said, would be amply compensated by the increased yield from the land rent. ${ }^{59}$

On October 5, he informed the Bengal Government of his measures, ${ }^{\theta 0}$ and ten days later issued a proclamation in which he outlined the principles of the intended change. The proclamation was to serve as official confirmation of the instructions already issued by Raffles to the Residents. ${ }^{61}$

1. The undue influence and authority of the Native Chiefs have been restricted: but Government avail themselves of their

Ibid., 30.

Hopkin's instructions referred only to the Regents of Puger and Banjuwangi, but Raffles' Minute of September 17, 1813, op. cit., included the Regent of Probolinggo among those who were to receive compensation.

58 Deventer, M. L. van, N.G., pp. 18-24.

59 Raffles to the Secret Committee, September 21, 1813, Java Separate Department Proceedings, September 23, 1813.

10 Raffles to Minto, October 5, 1813, Bengal Civil Colonial Consultations, February 15, 1814.

"Sub., 32. 
services in the important department of the Native Police, which will be arranged upon fixed principles, adapted to the habits and original institutions of the people. A competent provision in lands and in money has been allotted to such Chiefs, and it therefore naturally becomes both their duty and their interest, to encourage industry and to protect the inhabitants.

2. The Government lands will be let generally to the Heads of Villages, who will be held responsible for the proper management of such portions of the country as may be placed under their superintendence and authority. They will re-let these lands to the Cultivators, under certain restrictions, at such a rate as shall not be found oppressive; and all Tenants under Government will be protected in their just rights, so long as they shall continue to perform their correspondent engagements faithfully: for it is intended to promote extensive industry and consequent improvement, by giving the people an interest in the soil, and by instituting amongst them an acknowledged claim to the possession of the lands, that they may be thus induced to labour for their own profit and advantage.

3. The system of vassalage and forced deliveries has been abolished generally throughout the Island: but in the Batavian and Preanger Regencies such a modification of the former arrangements has been carried into execution, as it was found practicable, under existing circumstances, to introduce; and provisionally the Blandong system will be continued to a certain extent in the central Forest Districts.

4. To encourage the cultivation of so important an article of export as Coffee may become, when the trade of Europe and America may be thrown open to free competition, Government have stipulated to receive any surplus quantity of that commodity from the Cultivators, at a reasonable and fixed rate, when a higher price for it cannot be obtained in the Market.

5. To extend free trade and commerce, and to promote a spirit of enterprise and speculation amongst the inhabitants, the Bhoom Farms have been abolished, the duties upon the principal articles of export have been taken off, and it is intended to modify and amend the Custom-house Regulations before the 1st of January next. The toll-gates and transport duties of the interior have been diminished as much as possible, and in the gradual progression of improvement, they will be finally abolished. ${ }^{62}$

Only two weeks after this proclamation had been promulgated,

Ibid., pp. 174-5; Java Government Gazette, October 16, 1813. 
Raffles announced his intention of departing again for the Eastern Districts. He claimed that the journey was necessary, in order to complete the land rent settlements in those districts. He left Batavia on November 2 in the company of his wife. It is an intriguing question why Raffles departed for the Eastern Districts in such haste, and so soon after he had returned from there. If we can answer that question correctly, we may also have the answer to the more important question - why, only four months after he had given orders for the village settlement of the land rent did he revoke them, and order instead the introduction of the individual, or Ryotwari, system of revenue collection? 


\section{RAFFLES' CONVERSION TO THE RYOTWARI SYSTEM}

In his Minute of June 14, 1813, Raffles had stated that lands were to be leased "as near the actual cultivator as possible", and that generally this was to be achieved by renting lands to the Bekels, Lurahs and other village chiefs. ${ }^{1}$ Muntinghe understood that his intention was to lease lands as far as was possible "to the lowest class of inhabitants, and to the actual occupiers and cultivators of the ground". 2 As we have seen, Raffles had actually given instructions, both to Yule in Bantam, and Hopkins in the former Chinese districts of the Oosthoek, which suggested a detailed settlement of the land revenue. ${ }^{3}$ There is, therefore, much to be said in support of Raffles' later contention that he had always aimed at a detailed settlement of the land rent throughout Java. ${ }^{4}$

On the basis of this evidence, Dr. Wright has described as "unjust" the arguments of Dutch historians that between October 1813, and February 1814, Raffles introduced the detailed system because he had heard that the Ryotwari system was in favour with the home authorities. ${ }^{5}$ But Wright's argument has obscured the incontrovertible fact that between October 15 when the proclamation ordering village settlements was promulgated, and February 11, 1814, when the land rent Minute was penned, Raffles' ideas on the question of the revenue settlements changed considerably. One cannot read the following passage from a letter which he wrote in October, without realizing not only that Raffles at that time thought that the village settlements would continue for a considerable period, but that he considered the village chiefs in quite a different light from that in which he saw them four months later.

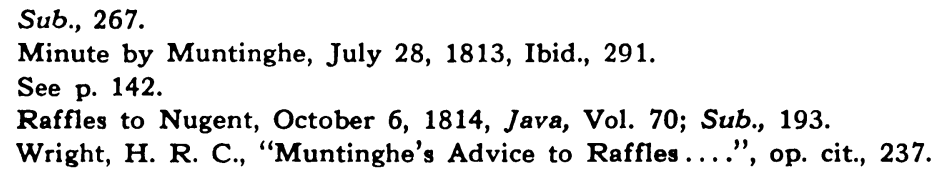


In the first instance, the lands are let, generally speaking, to the heads of villages, as this description of people appear to me to be the resident superintending farmers of the estate. In so extensive a population, there will naturally require some deviations in different districts: - but the plan of village rents will generally prevail. After the experience of one year, - leases for three years will be granted; and, at the conclusion of that period, the leases may either be made for seven, or for ten years, or the lands granted to the actual possessors in perpetuity. ${ }^{6}$

In order to deny any fundamental change in Raffles' ideas between October and February, Dr. Wright contended that Raffles remained purposely evasive on the question of detailed settlement, until Minto, the supporter of the Zamindari system, left India. ${ }^{7}$ But this is a most unsatisfactory explanation. Of all things which Raffles might have done, he would not consciously have alienated his patron, whose support he not only required while Minto was in Bengal, but also expected it in the councils at home.

The explanations most commonly offered to account for the change in Raffles' ideas between October and February are firstly, that he became aware after October of the tyrannical nature of the village headmen; ${ }^{8}$ or secondly, that shortly after giving instructions for the introduction of the village settlements he heard of the Ryotwari system in the districts under the Madras Presidency; ${ }^{\boldsymbol{\theta}}$ and so determined to proceed with that type of settlement in Java. The first of these explanations is unsatisfactory because of the time factor involved. Raffles' conversion to the Ryotwari system occurred, in fact, during the six weeks after October 15 , for it was at the end of November that he gave instructions to Lawrence to introduce that type of settlement into Kedu. ${ }^{10}$ Thus there was hardly time for the village chiefs to have shown any oppressive characteristics in the new settlement. When Raffles referred to these chiefs as tyrants

(3 Raffles to Elton Hammond, October 1813, Lady Raffles, Memoir, 194. Italics mine.

7 Wright, H. R. C., “Muntinghe's Advice to Raffles ....”, op cit., 245.

8 Schoutendorp, J., Schets van de Geschiedenis der Landrente op Java, (1874), 12. See the opinion of the Minister of Colonies in 1863, Deventer, S. van, L.S., I, pp. 203-4, footnote *); Encyclopaedie van Nederlandsch-Indië, (second edit.), I, 235 sub. "Belastingen".

y Norman, H. D. Levyssohn, op. cit., 215, footnote 1; Day, C., op. cit., 178; Klerck, E. S. de, II, 54.

10 See pp. 167-9. 
in February 1814, ${ }^{11}$ he was not talking from experience, but from a theoretical standpoint based upon the discovery of new facts regarding their status in the native society. The second argument, that Raffles heard of the introduction of the Ryotwari system in British India sometime after he had made his plans for village settlements, has much to be said in its favour. We must endeavour to trace the source from which Raffles learned of this system.

Before October 1813, although Raffles referred to a "detailed" system of revenue collection, he never used the word Ryotwari. He was, therefore, surprised to learn that a system of land revenue so like that suggested for Bantam and the Oosthoek was in operation in India. He wrote to Minto on February 13, 1814: ${ }^{12}$

The principles of the ryotwar settlement had suggested themselves, without my knowing that they had been adopted elsewhere; and although I may not easily gain credit for the original design, the promoters and supporters of that settlement will, no doubt, find a strong argument in its favour, from the circumstances of its having been so early and so easily adopted in a foreign and distant colony.

Clive Day called Raffles' candour into question when he found a so-called "inconsistency" between this statement, and that made by Raffles in the Minute of February 11, 1814, written two days earlier. ${ }^{13}$ In this Minute Raffles referred to the Ryotwari settlement "as it is termed in Western India, where is is understood to have been advantageously introduced". ${ }^{14}$ But the inconsistency is resolved if we read Raffles' letter to Minto as simply informing his Lordship of the fact that he had favoured the principle of a "detailed" settlement before he had heard of the word Ryotwari, or of its application to a similar type of settlement in British India. Raffles mentioned in the same letter to Minto that he had just received a copy of the Fifth Report. But Raffles' letter is not to be read as if it was simply the arrival of that Report which had made him aware of the similarity of the system he had ordered to be introduced into the Oosthoek districts, to that in the Madras Presidency, but rather that he had heard of the Ryotwari settlement sometime after October, and at that time he was surprised to learn of the similarity between the

11 Sub., 115.

12 Lady Raffles, Memoir, 224.

13 Day, C., op. cit., 178, footnote 1.

14 Revenue Instructions, February 11, 1814, Sub., 194. 
two systems. It is a delicate point, but it resolves Raffles' supposed inconsistency. From whom then did Raffles learn of the Ryotwari settlement after October 15, 1813? According to him not from the Fifth Report. ${ }^{15}$ The answer, I think, is to be found in David Hopkins' Report on the Oosthoek districts of Java. But before we discuss this question further, it is well that we consider the influence of Mackenzie, Muntinghe and Dirk van Hogendorp upon the development of Raffles' ideas on the land rent system in Java.

\section{Mackenzie's Influence on Raffles.}

It had been argued that it was Mackenzie, the Surveyor-General on the Madras Establishment, who suggested the idea of the Ryotwari settlement to Raffles. ${ }^{16}$ On Mackenzie's departure from Java, Raffles certainly praised him for his labours on the Land Tenure Commission. ${ }^{17}$ But nowhere did Raffles refer to his indebtedness to the Surveyor-General for his ideas on the land rent system. Indeed, Mackenzie's enquiries, and the statistical information which he supplied, merely "justified the opinion, that the Native Inhabitants of Java are susceptible of the improvements which a more enlightened administration in British India has dictated, and the Revenues of the Colony are of sufficient importance and consideration to bear every expence, charge and trouble attending their collection under such an improved system". ${ }^{18}$ Mackenzie's activities, in other words, provided the justification for the introduction of a programme of reform which Raffles had found elsewhere. ${ }^{19}$ Moreover, it is quite certain that Mackenzie knew much less about revenue matters in British India than has generally been allowed. In his Report of August 1812, he had mentioned the work of Read in the Báramahal, and that of Munro in the Kánara and the Ceded Districts, ${ }^{20}$ but he had not stated any of the principles which had guided their settlements. Indeed, Mackenzie added this very informative footnote to his remarks: ${ }^{21}$

15 Raffles to Minto, February 13, 1814, Lady Raffles, Memoir, 224.

16 Dodwell, H. H., op. cit., II, 596.

17 Java Government Gazette, July 17, 1813.

18 Loc. cit.

19 Sub., pp. 5-6; Proclamation of October 15, 1813, Ibid., 173.

20 See p. 23.

21 The footnote does not appear in the copy of the Report in Mack. Coll., (Pr.), Vol. 35, No. 20, but is in the copy recorded in Bengal Civil Colonial Consultations, March 19, 1814. 
The very limited knowledge of the writer of the Revenue System of India being chiefly derived from these sources, and from private communication of friends on the Madras Establishment, will excuse his mentioning here some of the authorities only with which he is acquainted, tho' he believes these are founded on the System recommended by the Court of Directors and in consequence of the general principles adopted by the British Legislature particularly since $1782 \ldots$

It seems fairly certain that Mackenzie never used the word Ryotwari in any of his discussions with Raffles, and that the latter only heard of the term after Mackenzie had left Java. If this seems strange, what is decidedly more puzzling is the fact that although Mackenzie was familiar with Dirk van Hogendorp's ideas, he never mentioned them to Raffles.

\section{Dirk van Hogendorp and Raffles.}

Most historians who have written on the subject of Raffles' land rent system have pointed out the great similarity between Van Hogendorp's ideas and those of Raffles. ${ }^{22}$ Little effort, however, has been made to trace the exact influence of Van Hogendorp's proposals upon him. In the History of Java written in 1817, Raffles admitted that the principles of the land rent system had been previously suggested by Van Hogendorp, but he claimed that the Berigt had come into his possession "subsequently to the introduction of the new system by the British government". ${ }^{23}$ In a Minute of August 4, $1815,{ }^{24}$ Raffles explained how he first heard of Van Hogendorp's proposals, and pointed out the "extraordinary coincidence" between their views. ${ }^{25} \mathrm{He}$ cited a passage from the Berigt, ${ }^{26}$ which he said had been shown to him by Muntinghe only a week previously. Raffles continued: ${ }^{27}$

Had I an idea that such a plan was ever proposed for this Island, and such advantages pointed out, I should have con-

Colenbrander, H. T., Koloniale Geschiedenis, (1925), II, 320; Stapel, F. W., Geschiedenis van Nederlandsch-Indië, (1930), 228; Day, C., op. cit., 170; Burger, D. H., op. cit., 59.

$23 H$. of J., I, 155, footnote.

24 Java, Vol. 61, Part I.

25 Loc. cit.

28 Berigt ...., op. cit., pp. 35-6; 46-8.

27 Minute by Raffles, August 4, 1815, op. cit. 
sidered it due to the author to have acknowledged the fact, and borne testimony to the accuracy of judgement displayed. As it is, I can only now bring it forward in corroboration of the System which we introduced without this previous knowledge; and further to shew that the general views and information which induced me to persevere in effecting the change were neither hastily formed, nor without foundation.

But as Dr. Wright has shown, ${ }^{28}$ Raffles had first heard of Dirk van Hogendorp's name as early as 1810 , when he was at Malacca. It is doubtful, however, that at that time he was familiar with Van Hogendorp's proposals for a reform of the colonial system.

What Raffles saw at Malacca was a list of figures entitled "A Calculation of what the Island of Java, if well Governed with freedom of Cultivation, Commerce and Navigation is Capable of Producing - by Mr. D. van Hogendorp, Director of Surabaya written in $1810^{\prime \prime} \cdot{ }^{29}$ [sic]. When he forwarded the document to Minto, Raffles added this note: ${ }^{30}$

The revenue that is now raised in Java would not be a fair criterion to judge by - a more just estimate of the resources of this important country might perhaps be formed on the Statement of Mr. Hogendorp, which I have annexed with the view of exhibiting a general idea of what Java under a liberal policy has been supposed to be equal to in the hands of the Dutch.

The table of figures was, in fact, Van Hogendorp's Calculative Berekening. ${ }^{31}$ The only statement in it which referred remotely to the subject of land rent, or more properly tax, was the estimate made that such a tax would produce $f \mathbf{8 , 0 0 0 , 0 0 0}$ a year if introduced. It is difficult to see how Raffles could have derived any ideas on the subject of colonial reform from that bare statement. ${ }^{32}$ Nevertheless

28 Wright, H. R. C., "Muntinghe's Advice to Raffles....", op. cit., 237.

28 Java, Vol. 13.

30 Raffles to Edmonstone, February 10, 1811, Ibid.

31 "Calculative Berekening van de Inkoomsten en Voordeelen, die het Eiland Java, onder een Goed Bestuur, zoude kunnen opleveren....", Stukken raakende de tegenwoordigen toestand der Batassche Bezittingen in OostIndië...., (1801), between pp. 399-403.

32 At the bottom of the figures, Raffles wrote: "The above statement by Mr. Hogendorp is extracted from his Memoir, which was sent out to Java to be replied to by the Councillors of India. Their replies tho' sufficient to prevent the plan proposed from being adopted, by no means confute the 
it was Van Hogendorp's ideas which Muntinghe began to ply him with shortly after the conquest of Java, although Van Hogendorp's name was never mentioned in these discussions. Sillem has stated that Muntinghe's reluctance to refer to Van Hogendorp by name was because the latter was considered to be too much of a revolutionary. ${ }^{33}$ But a more important and immediate reason was that Muntinghe had a personal dislike of the man.

Muntinghe had had various conversations with Mackenzie in connection with the work of the Land Tenure Commission, and it was during these discussions that Muntinghe mentioned Van Hogendorp's proposals regarding the land rent. Mackenzie immediately ordered a translation of the Berigt, ${ }^{34}$ and on April 28, 1813, had asked Muntinghe to give him a written statement regarding Van Hogendorp's proposals. ${ }^{35}$ Muntinghe's reply showed quite clearly his dislike of him. The Berigt, he told Mackenzie, had created some interest for a short time after its publication, "but as soon as the inconsistency of the whole was fully detected, it lost all its credit". All Van Hogendorp's efforts to cover these inaccuracies "were in vain, 8 he lost his character with the public entirely". However, by party spirit, and "by personal interest, he obtained some influence with a few in the administration, but their endeavours to protect him $\&$ to obtain his appointment as Governor General of the Indian Possessions, were constantly resisted by the majority, $\&$ made them but the more averse to any change of system". Ironically enough, Muntinghe had the greatest respect for Nederburgh. He thought Gijsbert Karel

verity of the statements. They contain, however, much useful information respecting Java, political and commercial, the most important points of which are in the course of translation". Raffles was referring to "Kort vertoog' van den Gouv.-Gen. Siberg, omtrent het 'Berigt' van D. van Hogendorp"; "Consideration van den Directeur-Gen. A. H. Wiese...."; "Consideratien van den raad extraordinair van Indië... van IJsseldijk op het werk van... Dirk van Hogendorp....", Jonge, J. K. J. de, De Opkomst van het Ned. Gezag in Oost-Indië, (1888), XIII, pp. 39 et seq. Whether these were ever translated for Raffles is uncertain.

Sillem, J. A., op. cit., pp. 361-2.

34 There is a note in Mackenzic's handwriting to a "Memoir" written by Muntinghe, July 16, 1813, Mack. Coll., (Pr.), Vol. 13, No. 17 (c) which reads: This work [the Berigt] was translated in $1812-13$, \& a copy sent in to Government [in] February 1815".

"Memorandum of Queries addressed to Mr. Muntinghe", Ibid., No. 17 (b). The fifth query related to Van Hogendorp. 
much more preferable than his upstart brother. ${ }^{36}$

While Muntinghe's dislike of Van Hogendorp explains satisfactorily why he never mentioned, until a late date, his name to Raffles, it is strange that Mackenzie did not refer to Van Hogendorp in his conversations with the Lieutenant-Governor. The most likely explanation is that after he had ordered the translation of the Berigt in 1812, Mackenzie did not have the leisure to study Van Hogendorp's proposals in detail until he had reached Bengal towards the end of 1813. Mackenzie's statement that he forwarded a copy of this translation to Raffles in 1815 goes a long way to support Raffles' contention that he had never seen a copy of the Berigt until after the land rent system had been introduced. One difficulty, however, is that the translation which Mackenzie forwarded to Raffles was different from that which Raffles cited in the History of Java. ${ }^{37}$ There were, in other words, two translations of the Berigt made during Raffles' administration of Java, and of the second there is no trace.

Van Hogendorp had regarded a detailed settlement with each cultivator as desirable, ${ }^{38}$ but it is doubtful that he understood the exact difference between the Ryotwari and Zamindari systems. Whenever he endeavoured to show the practicability of his proposals, he always cited the successful working of the revenue system in Bengal. ${ }^{38}$ That this system gave a certain security of tenure there is no doubt, but that it resembled his proposals for establishing ownership of the ground among the ordinary Javanese, ${ }^{40}$ must be doubted. It would be tempting to argue that shortly after October 15, 1813, Raffles learned of Van Hogendorp's proposals for a settlement

Muntinghe, H. W., "Memoir", op. cit. Muntinghe stated that Gijsbert Karel "bore... quite a different character [from Dirk], \& stood in point of respectability, talents, wealth 8 independence at least on a level with $\mathrm{Mr}$. Nederburgh". Sillem, J. A., op. cit., 362, was almost certainly wrong when he ascribed Muntinghe's remark (cited on that page) as applicable to Dirk. Muntinghe was referring to G. K. van Hogendorp.

37 . of J., I, pp. xlii; $155-6 ; 225-7$, etc. What Raffles' cited as the title of Van Hogendorp's work (p. xlii) was not, in fact, the title of the Berigt, but one of the internal headings, p. 1.

38 Berigt...., op. cit. 38.

39 Ibid., 37; "Schets of Proeve....", op. cit., Eindresumé, II, Bijlage LL, 155. See Platteel, P. J., op. cit., pp. 37-8.

40 "Schets of Proeve....", op. cit. 155. 
with the individual cultivators, and so modified his village settlements. Unfortunately all the evidence is opposed to this suggestion.

\section{The Influence of Muntinghe on Raffles' Ideas.}

It was through Muntinghe that Raffles derived most of his ideas on the land rent question in Java. In his Minute of February 11, 1814, Raffles stated that Muntinghe had been "the link" ${ }^{41}$ which connected the liberal principles of the former Dutch administration, with those of his own. "It was Mr. Muntinghe," Raffles wrote, ${ }^{42}$ "who first pointed out to me the gross errors, and the still grosser corruptions, of the former Government; and it was from a confidence in his opinion, and a reliance on his unerring judgment, that I first conceived it practicable to work the change which has been wrought". When Muntinghe retired from the Java Council, Raffles was more lavish in his praise. ${ }^{43}$

[O]n the introduction of the new system of Land Rent throughout Java, the extensive local information of Mr. Muntinghe, his complete knowledge of the principles of general justice, and his intimate acquaintance with the native character and institutions were called into full exertion, and tended always to lessen, and frequently to remove the many obstacles, which could not but arise to the completion of so important a revolution in the internal administration of this Island.

While Muntinghe was undoubtedly the person who supplied Raffles with the ideas which Van Hogendorp had made so popular in the Berigt, he seems to have been more cautious than Van Hogendorp, who had advocated parcelling out the lands to the Javanese. ${ }^{44}$ Muntinghe was troubled during 1813 by Raffles' plans for suddenly removing the Regents from effective control over their districts, and in his Minute of July 28, had attempted to restrain Raffles' enthusiasm. It was doubtless Muntinghe who gave the strongest support in Council to Crawfurd's arguments that the land rent settlement should be based on the Bekels, Lurahs and other village chiefs. Let us now return to consider the question of Raffles' change of ideas on the subject of revenue settlements after October 1813.

1 Sub., 78. See Vlekke, B. H. M., op. cit., 245, note 19.

12 Sub., 78.

4:3 Java Government Gazette, August 6, 1814.

44 Berigt..., op. cit., 38. 
Crawfurd's reports on Kedu and Patjitan, and later his comprehensive exposition of land tenures in the Principalities, had a considerable influence on Raffles He had accepted Crawfurd's argument that the land rent system should be based upon the Bekels and village headmen, not only because of their familiarity with revenue matters under the native administration, but also because they were supposed to have held slightly more secure positions than others in the native hierarchy. ${ }^{45}$ Although Raffles had given orders to Yule in Bantam and Hopkins in the Oosthoek for the introduction of the detailed settlement of the land rent, he felt that this action had been justified only because the local chiefs had been removed, either by native usurpations, or by the Chinese. Raffles' proclamation of October 15, 1813, had been based upon the two principles enunciated by Crawfurd. The first was that the proprietary rights to the ground in Java were vested in the Sovereign (Government), ${ }^{46}$ and the second was that the Bekels were to be considered as the lessors in the settlement, because they had better claims than any others. In October, Raffles described the village chiefs as "resident superintending farmers", 47 and had thought that leases should be granted to them for long periods. However, shortly after he had issued the proclamation, he received a report which seriously challenged the latter principle, and in Raffles' eyes the whole justice of the settlement.

The report came from Hopkins, and related to conditions of land tenure in the former Chinese districts of the Oosthoek. ${ }^{48}$ Hopkins informed Raffles that he had found the tenures "very different from what it is reported to be in other parts of Java". ${ }^{49}$ The people east of Surabaya, he stated, had the right of electing every year their Petinggis, ${ }^{50}$ from which it was evident that "a certain right of soil actually belongs to the present occupier, either as he is the immediate clearer of the lands, or the heir or successor of that person". ${ }^{51}$ The former Chinese proprietors had left the people in

15 See p. 98.

46 Norman, H. D. Levyssohn, op. cit., 190.

47 Raffles to Elton Hammond, October 1813, Lady Raffles, Memoir, 194.

48 Sub., pp. $99-104 ; 146-51$.

49 Ibid., 100.

50 Loc. cit.

51 Ibid., 103. 
the private possession of their lands, a circumstance which Hopkins thought rendered " a personal settlement with each individual indispensable". ${ }^{52} \mathrm{He}$ argued against farming villages to individuals, and allowing them to make their own terms with the cultivators, because this would not improve the lot of the ordinary people. The only way of securing their relief, as well as achieving the greatest financial advantages for the Government, was "by making the rigotwar [sic] settlement, authorised in these districts, general through[out] the Island". ${ }^{53}$

The exact date of Hopkins' report is not known. But Hopkins had taken charge of the districts east of Bangil from Cotes on September $17,1813,{ }^{54}$ so that it was written some time after that date, and after he had received his instructions to introduce a detailed settlement of the land rent into the Oosthoek districts. Hopkins was one of the few officials in Java who possessed any exact knowledge of the revenue systems of British India, ${ }^{55}$ and there seems no doubt that when Raffles' instructions referred to the "detailed" settlement, Hopkins immediately read it as meaning Ryotwari. As soon as Hopkins discovered what he thought constituted individual proprietary rights in the Oosthoek, he was quick to point out to Raffles the apparent similarity between the tenures there, and those in Western India. ${ }^{56}$ It is almost certain that it was when reading Hopkins' report that Raffles first learned of the term Ryotwari. ${ }^{57}$

Hopkins' discoveries placed Raffles in a dilemma. The right of election seemed to him to imply certain individual rights to the soil,

54 De Haan, F., "Personalia", pp. 522; 581.

55 Ibid., 581. Raffles spoke of "the experience which this gentleman possesses in the revenue arrangements of Bengal".

56 Sub., 102.

57 One is struck by the similarity of the various references made by Raffles to the Ryotwari system at this period. In his instructions to Lawrence at the end of November, 1813, he referred to "the principles of the ryotwar settlement, which is understood to have been advantageously introduced in Western India;" (Ibid., 45.) and in the Revenue Instructions of February 1814, he talked of "the tiang-palit (or as it is termed in Western India, where it is understood to have been advantageously introduced, the ryotwar settlement)...".' (Ibid., 194.) The vagueness of the references, implied by the words "where it is understood", support the contention that Raffles did not learn of the term Ryotwari from any authoritative source. Raffles referred to his indebtedness to Hopkins in several places in the Substance, pp. $162 ; 77-8$. 
which had been denied in the village settlements. Moreover, Hopkins' advice regarding the extension of the detailed settlement to the other districts of Java, made a strong appeal to Raffles, who favoured the idea of a strong paternal government dealing directly with the people. The objection to the introduction of such a system previously had been the necessity of recognizing the rights of the village chiefs in the land rent settlement. But if the right to elect these chiefs were found to be vested in the common Javanese, Raffles could no longer see any objection to the introduction of the detailed system. It is possible that Hopkins' report reminded Raffles of the references to this right of election contained in Rothenbühler's two reports. ${ }^{58}$ In any case, he immediately circulated instructions to the Residents to investigate the matter. ${ }^{58}$ McQuoid saw the point of Raffles' query, particularly when he found the existence of elective rights in Djapara and Djuwana. ${ }^{.0}$

The right exercised by the inhabitants of a village to elect their own chiefs, and the jealous tenacity with which they appear to have preserved this right, it must be acknowledged, casts a shade of doubt over the opinion I have ventured to give, on the subject of landed tenures; for we can hardly reconcile to ourselves, that any community, possessing a privilege so valuable, as that of selecting the immediate chief whom they chuse to obey,... should not have also possessed a more defined and absolute claim upon the soil that gave them birth, than it would appear they now have.

McQuoid understood that this gave Raffles the necessary justification for proceeding with the introduction of the Ryotwari system throughout the island. ${ }^{61}$ The importance of the principle of election in relation to the detailed settlement was stated by Raffles himself. "I have been thus particular in defining the mode in which the head of a village is appointed," he wrote, ${ }^{62}$ "because, on this point has

See p. 66.

This is obvious enough, when one considers the similarity of the subject matter of the various reports cited by Raffles in the Substance. They all deal with the question of the right of election. As they were written between September 1813, and the following February, it would be too much to expect that all the Residents made this discovery at the same time. Obviously their attention had been drawn to the fact by Raffles. (See Sub., 162.)

Ibid., 107.

Ibid., 108.

Ibid., 113. 
appeared to hinge the principles on which our future regulations must be established."

Raffles became thoroughly disturbed when he began to receive confirmation of the right of election from all parts of Java. Particularly worrying was the report sent in by Crawfurd, who was then introducing the village land rent settlement into Tjirebon. That dour Scotsman, who had always defended the thesis that the Sovereign possessed full proprietary rights to the ground in Java, now informed Raffles that in $T$ jirebon he had found ${ }^{63}$

1st. That the right of private property in the soil is generally acknowledged, and tolerably well understood.

2d. That throughout the greater part of the country, the claim of the Sovereign to the proprietary right in the soil is unknown to the institutions of the country.

$3 \mathrm{~d}$. That the heads of villages, or Chutars, are generally officers of revenue and police, elected by the community. They superintend, or are at least always appointed, with a reference to their consent and approbation.

4th. That these have no claim, either official or hereditary, to the property of the soil, nor can they in any place be considered as tenants of it, like the Lurahs and Bakals of the Javanese districts.

5th. That the cultivators of the soil are generally the proprietors.

6th. That all cultivators, however, are not proprietors, though the latter be very numerous.

7 th. That the community may be divided with propriety into four classes, as follows: - native superintendants of districts, called Bopatis or Tumangungs; heads of villages and Chutars; cultivators who are proprietors; and cultivators who are either tenants or labourers.

8 th. That the claim of the Sovereign to a portion of the produce of the soil is clearly established and recognized.

It was apparently Hopkins' report which made Raffles decide to re-visit the Eastern Districts of Java during November and December 1813, for he wished to investigate in person the new problem regarding individual rights to the ground. This argument is not based upon an arbitrary dating of Hopkins' report. There is much other evidence to show that it was the discovery of the right possessed by the ordinary Javanese to elect his village headman,

63 Ibid., pp. 110-11. 
and the ramifications of that discovery, which caused Raffles to change his ideas on the question of the land rent system after October 15, 1813. This contention is supported by a careful reading of Raffles' Substance of a Minute, which was written in February 1814.

In the third section of the Substance, Raffles entered into a somewhat involved discussion about land tenures in Java, which he said justified the necessity of introducing the detailed settlement of the land rent. ${ }^{64}$ Despite the many long citations from reports, Raffles' argument is clear enough. He wished to show that the Bekels, Lurahs and other village chiefs, who had been granted leases in August and September, possessed no special rights which deserved consideration in a future settlement. That, in fact, the granting of leases to them constituted, in principle, an injustice to the cultivators, as they themselves possessed the right of electing those chiefs. In order to achieve some sort of consistency in his argument, Raffles had to reverse his earlier contention, that the land tenures in the Principalities were a guide to the state of tenures in the rest of the island. Raffles had written in June, 1813: ${ }^{65}$

On this point [the condition of the land tenures in Java generally] we may assume for a criterion, on which to form a [judgement], the state of landed tenure in the territories of the Native Princes; because it is there that the Javanese laws and customs, in the present modification, since the Mahomedan religion was introduced, must be found to exist in the greatest perfection.

Six months later, he completely reserved this opinion. It was in the coastal districts, those furthest removed from the corrupting influences of the Courts, that the ancient institutions of the country were best preserved. ${ }^{66}$ Raffles had been forced into this conclusion, because he had to deny the applicability of Crawfurd's findings regarding land tenures in the Principalities to the coastal districts of Java. For Crawfurd had found slight hereditary claims among the Bekel class in the districts under native control, ${ }^{67}$ and it was

(i4 Ibid., 169.

(i5 Minute by Raffles, June 14, 1813, Ibid., 255.

(i) Ibid., pp. 98; 81. Van Vollenhoven missed the significance of this change in Raffles' ideas, De Ontdekking van het Adatrecht, 29.

ii See p. 98. 
precisely this point which Raffles now wished to deny. Raffles argued that in the light of the recent discoveries in the coastal districts, it would be unjust to apply conclusions reached from in vestigations in the Transferred Districts and the Principalities indiscriminately. He wrote: ${ }^{88}$

From Mr. Crawfurd's report on the settlement of Cheribon, it is obvious, that however applicable his former observations might have been to the Native Provinces, the Bakal system, which he was desirous to establish, was by no means capable of general application throughout the country; for notwithstanding he strongly recommends, in his Report on the Cadoe, ${ }^{6 \theta}$ that the Bakals, or village chiefs, should, as the occupants, be considered and established as the permanent landholders, it will be found from the Reports above quoted, and also from his own observation on the tenure in Cheribon, that the heads of villages are very differently appointed and constituted, from the manner represented by him to have effect in the provinces of the Native Princes.

Not that Raffles agreed altogether with Crawfurd's findings in Tjirebon. He disagreed particularly with his contention that the Sovereign there possessed no proprietary rights to the soil. ${ }^{70}$ Raffles had to have the principle of sovereign rights to the ground unimpaired, in order to justify the whole of his land rent system. But he was very willing to admit certain occupancy rights among the cultivators, so long as they did not challenge seriously the principle of sovereignty possessed by the Government. The recognition of individual rights to the ground removed the necessity of using any intermediate agency in the land rent settlements. ${ }^{71}$ The village chiefs were not in fact landlords at all, but the representatives of the people. To have regarded them in any other way would have been an injustice to the cultivators. As Raffles stated in his instructions to Lawrence at the end of November 1813: ${ }^{72}$

[T]o establish the Bakal as the hereditary landholder, and to allow him to sub-let the land of a village at pleasure, would be to grant him an authority and independence, which never

\footnotetext{
Sub., pp. 109-10.

See pp. 99-101.

Sub., pp. $110-11$.

Ibid., pp. 6-7.

Ibid., 113; 45.
} 
could have been expected, and to arm him with power prejudicial to the happiness of the people, and repugnant to the object which Government had in view, towards the amelioration and improvement of the mass of the population.

One cannot compare this statement with the proclamation of October 1813, without realizing the great development which had taken place in Raffles' ideas during the short space of six weeks. Earlier the trend of his ideas had suggested a detailed settlement where this had been possible, but in October he had considered the village chiefs as necessary agents in the establishment of the new system in the coastal districts. By the following February, however, the discoveries relating to land tenures necessitated their removal as renters of the lands. ${ }^{73}$

The nature of landed tenure throughout the Island is now thoroughly understood. Generally speaking, no proprietary right in the soil is vested in any, between the actual cultivator and the sovereign; the intermediate classes, who may have at any time enjoyed the revenues of villages or districts, being deemed merely the executive officers of Government, who received those revenues only from the gift of their lord, and who depended on his will alone for their tenure. Of this actual proprietary right, there can be no doubt that it originally [was] vested solely in the sovereign; but it is equally certain, that the first clearers of the land entitled themselves, as their just reward, to such a real property in the ground they thus in a manner created, that whilst a due tribute of a certain share of its produce for being well governed was paid to the sovereign power, which, in return, was equally bound not to disturb them or their heirs in its possession. The disposal of this Government share was, therefore, all that could justly depend on the will of the ruling authority; and consequently, the numerous gift[s] of lands, made at various periods by the several sovereigns, have in no way affected the rights of the actual cultivators. All that Government could alienate, was merely its own revenue or share of the produce. This subject has come under full discussion; and the above result, as regarding this Island, has been quite satisfactorily established.

The continuance, therefore, of the village system becomes only a matter of consideration, on the grounds, whether it is more beneficial than any other to Government, or most likely to be conducive to the general prosperity and welfare of the mass of population?

Revenue Instructions, February 11, 1814, Ibid., pp. 193-4. Italics mine. 
No doubt, however, remains on the minds of Government on this question. The agency of intermediate renters is considered as quite unnecessary to be adopted in future. It is deemed, that such a plan of settlement will leave the interests of the bulk of the people entirely at the mercy of a numerous set of chiefs, who, however well they may have hitherto conducted themselves, would certainly, in such case, possess an ability of injury and oppression, against which the ruling power would have left itself no adequate means of prevention or redress, and which cannot therefore be permitted, consistently with the principles of good government.

Let us now consider the course of Raffles' journey through the Eastern Districts of Java during the closing months of 1813, and the progress which had been made in the introduction of the village land rent settlements. 


\section{THE LAND RENT ASSESSMENTS OF 1813}

\section{Tiirebon.}

Although Crawfurd discovered individual proprietary rights in Tjirebon, he still wished to establish a village settlement of the land rent in the Residency. Raffles praised Crawfurd's settlement in his Minute of the following February, ${ }^{1}$ although by then he was a firm opponent of the system. Crawfurd completed his work in Tjirebon in December, and departed for Yogyakarta.

Raffles had visited Tjirebon on November 6 . He found that Crawfurd had commenced a yearly settlement on the village chiefs, ${ }^{2}$ at a gross assessment of 218,736 J.Rs. ${ }^{3}$ After deducting a sum of $34,270 \mathrm{~J}$. Rs., which was the estimated value of the lands assigned to the chiefs, ${ }^{4}$ the net land rent was calculated at $184,466 \mathrm{~J}$. Rs. $^{5}$ This was expected to yield a surplus revenue for the Residency of a little more than 150,000 J. Rs. ${ }^{\theta}$ This sum alone, Raffles reported to Nightingall, ${ }^{7}$ was equal to the gross amount of all receipts in any former year. He later claimed that the Resident, Lieutenant-Colonel Raban, had experienced no difficulty in raising the total amount of the rent in cash. ${ }^{8}$

\section{Tegal, Brebes and Pemalang.}

Raffles spent three days in Tjirebon, from whence he proceeded to Tegal. A village settlement had also been made there by Major

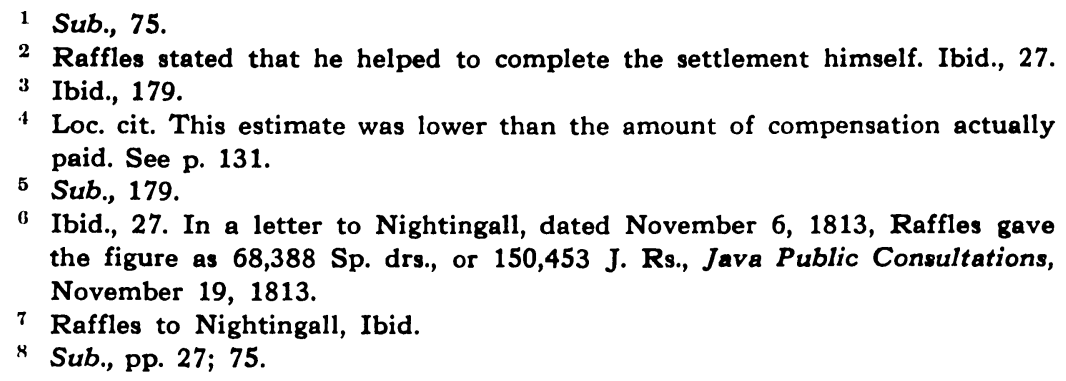

4 Loc. cit. This estimate was lower than the amount of compensation actually paid. See p. 131.

5 Sub., 179.

a Ibid., 27. In a letter to Nightingall, dated November 6, 1813, Raffles gave the figure as 68,388 Sp. drs., or 150,453 J. Rs., Java Public Consultations, November 19, 1813.

7 Raffles to Nightingall, Ibid.

× Sub., pp. 27; 75. 
Keasberry, and his assistant W. Davies. ${ }^{9}$ Raffles stated three months later that the condition of the native population in Tegal was not far enough improved to begin a detailed settlement. ${ }^{10}$ But the truth of the matter was that as the village settlement had already been completed, Raffles could have done little to upset it. Nevertheless, he made some provision for a future detailed settlement by writing into the leases given to the Petinggis a stipulation that they should secure to the Javanese the full enjoyment of their property according to the established custom. ${ }^{11}$ The first assessment of the land rent at Tegal was $180,489 \mathrm{~J}$. Rs. per annum. ${ }^{12}$ After allowing a deduction of $21,111 \mathrm{~J} . \mathrm{Rs}$. for rents of the lands granted to the chiefs as compensation, ${ }^{13}$ a net land rent of $159,378 \mathrm{~J}$. Rs. was expected..$^{14}$ It was thought that this would produce a surplus of $130,845 \mathrm{~J}$. Rs. over disbursements. ${ }^{15}$ The land rent of Tegal was to be paid onethird in silver, and two-thirds in copper. ${ }^{16}$

\section{Pekalongan, Ulujami and Batang.}

The first land rent settlement of Pekalongan made by Hardy was something of a fiasco. In June 1813, Lawrence was appointed to succeed him with instructions to prepare for a fresh assessment when Hardy's village settlement expired. No sooner had Lawrence taken charge of Pekalongan than the Chinese proprietor of Ulujami, Tan Tjan Kong, died. Raffles ordered the immediate resumption of the district by the Government. ${ }^{17}$ This decision was prompted by the fear of a similar rising to that in Probolinggo. When Lawrence took charge of Ulujami in June, he was instructed to introduce the land rent system there.

* De Haan, F., "Personalia", pp. 590; 532; Sub., pp. 75-6.

10 Sub., 33.

11 Loc. cit.

12 Ibid., 179. The figure given Ibid., 33, included the tenement tax. In a letter to Nightingall on November 13,1813, Raffles stated that the land rent of Tegal had been fixed at $82,268 \mathrm{Sp}$. drs., Java Public Consultations, November 19,1813 . This was a slightly higher figure than that given in the text above.

13 Sub., 179. This estimate was lower than the later calculation of the rent of these lands. See p. 132.

14 Sub., 179.

15 Ibid., 33. In his letter to Nightingall, November 13, 1813, op. cit., Raffles gave the slightly higher figure of $63,495 \mathrm{Sp}$. drs.

16 Raffles to Nightingall, November 13,1813 , op. cit.

17 Sub., 34. 
The first settlement of Ulujami was made by granting leases to the Bekels for a period of three years. ${ }^{18}$ Rents were to be paid in money, but an option was to be given to the cultivators to make a portion of their payments in rice at the average market price. ${ }^{19}$ Raffles stated later that he had been forced to grant longer leases in Ulujami than he had desired, because he had wished to restore confidence among the population following the oppressive administration of the Chinese. ${ }^{20}$ In order to secure uniformity in the whole of the Pekalongan Residency, the triennial village leases were extended throughout. ${ }^{21}$ Lawrence found some difficulty, probably because of Hardy's earlier faulty settlement, in issuing all of these leases at the same time, and was forced to grant them at different periods. ${ }^{22}$ The Government, however, reserved the right of reassessing the lands at the end of the first year..$^{23}$

Raffles stated that Ulujami was "the first district in which the new revenual system was introduced", ${ }^{24}$ but this is to be read as "first" after his land rent Minute of June 1813, as Lawrence's settlement of Ulujami was made in July and August of that year. ${ }^{25}$ De Salis stated in September 1816 that a detailed settlement had been effected in Ulujami, while the village system continued in the other districts of Pekalongan. ${ }^{26}$ But Raffles never listed Ulujami among the districts where the Ryotwari system had been introduced, and Bauer and Addison, who visited Ulujami in August of 1814, referred to the village system being in operation there. ${ }^{27}$ However, the village chiefs of Ulujami had been required to write on the back of their leases the names of the cultivators, the amounts of lands they held, and the

18

18

20

21

22

Ibid., 34. One can infer from De Salis' "Verslag over den waren aard der Britsche Administratie in de Residentiën Pekalongan en Kadoe", (Deventer, M. L. van, N.G., 91) that the last lease was granted on September 31, 1813.

23 Sub.; pp. 38-9.

24 Ibid., 35.

$\mathbf{2 5}$ . In a despatch to Minto dated July 11, 1813, Raffles reported that the land rent system was then being introduced into Pekalongan, Bengal Civil Colonial Consultations, December 18, 1813.

20 Salis, A. M. T. de, "Verslag over... Pekalongan en Kadoe", op. cit., 92.

27 Bauer and Addison, Report on Pekalongan, August 9, 1814, Ratfles Collection, V, No. 4 (iii). 
rent each of them had to pay. This information was kept at the Resident's Office for easy reference, and the Government did not hesitate to interfere in the disputes which arose between the cultivators and the renters. ${ }^{28}$ There were, therefore, certain features in the Ulujami arrangements which resembled the later detailed settlements.

The first land rent assessment of Ulujami is not known, although Raffles stated in 1814 that its net revenue was equal to four times the amount which had been yielded under the Chinese administration. ${ }^{2 \theta}$ From this we may infer that the net revenue was somewhere between 18,000 and $20,000 \mathrm{Sp}$. drs., since the annual rent which had been paid by the Chinese was between 4,612 Sp. drs. and 4,980 Sp. drs.

The land rent assessment of the Pekalongan Residency as a whole, was established at $260,338 \mathrm{~J}$. Rs. ${ }^{30}$ which was more than double the former contingent and recognition money. ${ }^{31}$ This was expected to produce a net surplus revenue for the Residency of $121,734 \mathrm{Sp}$. drs., $(267,814$ J. Rs.), which was nearly double the amount af the gross revenue of any previous year. ${ }^{32}$ Raffles informed Nightingall in November 1813, that the coffee gardens and forests had been let as waste land, and were not to be assessed for rent for a period of three years. ${ }^{33}$ Lawrence had already begun clearing the forest of Kadawang in order to put it into cultivation on this principle of exemption.

On the completion of the Ulujami settlement, Raffles ordered that a similar settlement be made in Batang, ${ }^{34}$ and Wiradesa. ${ }^{35}$

Lawrence granted lands and money to the Tumenggungs and other chiefs in the Pekalongan settlement as follows: ${ }^{36}$ 


\begin{tabular}{|c|c|c|c|c|c|c|c|}
\hline \multirow[t]{2}{*}{ Chiefs } & \multirow{2}{*}{$\begin{array}{c}\begin{array}{c}\text { Quantity } \\
\text { of } \\
\text { Sawahs }\end{array} \\
\text { Jungs }\end{array}$} & \multicolumn{2}{|c|}{$\begin{array}{l}\text { Assessed value } \\
\text { of land per } \\
\text { annum }\end{array}$} & \multicolumn{2}{|c|}{$\begin{array}{l}\text { Money } \\
\text { grants }\end{array}$} & \multicolumn{2}{|c|}{$\begin{array}{c}\text { Total value } \\
\text { of land and } \\
\text { money grants } \\
\text { p.a. }\end{array}$} \\
\hline & & J. Rs. & Sts. & J. Rs. & Sts. & J. Rs. & Sts. \\
\hline $\begin{array}{l}\text { Tumengsung of } \\
\text { Pekalongan and } \\
\text { Wiradesa }\end{array}$ & $154 \% 8$ & 4,771 & 24 & 2,640 & - & 7,411 & 24 \\
\hline $\begin{array}{l}\text { Head Pangulu } \\
\text { and "Priests" of } \\
\text { Pekalongan and } \\
\text { Wiradesa }\end{array}$ & $501 / 8$ & 1,267 & 6 & - & - & 1,267 & 6 \\
\hline $\begin{array}{l}\text { Head Djaksa of } \\
\text { Pekalongan and } \\
\text { Wiradesa }\end{array}$ & $51 / 4$ & 184 & 24 & - & - & 184 & 24 \\
\hline $\begin{array}{l}\text { Late Tumens\&ung } \\
\text { of Wiradesa }\end{array}$ & $18^{15} / 18$ & 666 & 18 & - & - & 666 & 18 \\
\hline Patih Dalem & 16 & 211 & 6 & - & - & 211 & 6 \\
\hline $\begin{array}{l}\text { Brother to the } \\
\text { late Adipati of } \\
\text { Pekalongan }\end{array}$ & 4 & 105 & 18 & - & 一 & 105 & 18 \\
\hline Former Patih & 1 & 20 & 27 & 一 & - & 20 & 27 \\
\hline $\begin{array}{l}\text { Former Raden of } \\
\text { Batang }\end{array}$ & $11 \%$ & 367 & 13 & - & - & 367 & 12 \\
\hline $\begin{array}{l}\text { Tumengsung of } \\
\text { Batang }\end{array}$ & $1531 / 2$ & 4,847 & 21 & 2,640 & - & 7,487 & 21 \\
\hline $\begin{array}{l}\text { Pangulu and } \\
\text { "Priests" of Batang }\end{array}$ & 30 & 811 & 24 & - & - & 811 & 24 \\
\hline TOTAL & $444^{13} / 16$ & 13,255 & - & 5,280 & - & 18,535 & - \\
\hline
\end{tabular}

\section{Kedu.}

Raffles left Pekalongan on November 22 for Semarang. On the 28th he departed from Semarang in the company of his family for Serondol, and on the 29th, accompanied by Robinson, Skelton, Taylor and Eckford entered Kedu on a two day visit. He was met by Lawrence, and his assistant Heyland. ${ }^{37}$

37 Java Government Gazette, December 11, 1813. 
Crawfurd had made the first land rent settlement of Kedu in September 1812.38 Early in the New Year Lawrence was appointed to succeed him as Resident. ${ }^{39}$ But in May he was given the additional charge of Pekalongan, ${ }^{40}$ with instructions to introduce the land rent system there. From the beginning of June until the end of August, Lawrence was fully occupied in Ulujami and Pekalongan, and it was only in September that he was able to turn his attention once again to Kedu. Towards the end of that month, he addressed a letter to the Java Council in which he stated that he was about to begin the land rent settlement of $\mathrm{Kedu}{ }^{41}$ This referred to the necessity of extending the annual leases granted by Crawfurd in the previous year. However, Lawrence received no instructions until Raffles entered Kedu at the end of November. During the discussions, Lawrence impressed on the Lieutenant-Governor that the earlier assessment was not high enough when compared with the resources of the district. He thought that a more regular assessment was essential. ${ }^{42}$ After a few hasty enquiries, Raffles gave him instructions to begin the introduction of a detailed settlement of the land rent. These instructions showed clearly the influence of the discovery relating to the election of village headmen in the coastal districts. They also contained the first reference made by Raffles to the term Ryotwari.

It has been a question with Government, how far either the Bakals or Demángs ought to be considered in the light of landholders, as suggested by Mr. Crawfurd in his Report on the Cadoe; and on a due consideration of the rights and pretensions of all classes, it has been considered, that there does not exist any proprietary right in the soil between the actual cultivator and the Sovereign, to establish the Bakal as the hereditary landholder. To allow him to sub-let the land of a village at pleasure, would be to grant him an authority and independence which never could have been expected, and to arm him with power prejudicial to the happiness of the people, and repugnant to the objects which Government have in view, in effecting the amelioration and improvement of the mass of the population.

38 See pp. 99-101.

39 De Haan, F., "Personalia", pp. 527; 595.

40 Ibid., 595.

41 Java Public Consultations, September 28, 1813. Lawrence's letter was not recorded in full.

42 Sub., 44. 
You will, in consequence, proceed to effect such a detailed settlement of the revenue, as will include a consideration of the interests of every individual claimant of land in each village, and adopt, as far as local circumstances may admit, the principles of the ryotwar settlement, which is understood to have been advantageously introduced in Western India. The modifications in this settlement are, of course, left to your discretion and judgment.

Under this system, the Bakals, or heads of villages, may be entrusted with the police, and the collection of the land rent of each village; but instead of leases being granted to them, as first suggested, they should receive a commission according to the form enclosed: and, as far as it may be found practicable, a short certificate should be given to each landholder in the village, defining the extent of his property, and the amount of the rent he has to pay annually. ${ }^{43}$

Lawrence set about his task with a will. By the end of December he was able to report to Raffles on the facility with which the new settlement had been made in one district of Kedu, and of his hopes of it being rapidly extended to the other parts of the Residency. ${ }^{44} \mathrm{He}$ informed his superior that on the basis of the assessment of the first district, the detailed settlement of the whole of Kedu would produce an augmentation of revenue of something like $70 \%$, after allowing for compensation to the chiefs. ${ }^{45}$ The gross assessment of Kedu was stated to be $419,760 \mathrm{~J}$. Rs. in February, $1814 .^{46}$ This was in excess of Lawrence's earlier estimate. In Kedu, the charges of the Native Establishment, and the compensation granted to chiefs, were all paid in cash, so that there were no deductions made from the gross rental. ${ }^{47}$

\section{Grobogan, Djipang and Wirosari.}

A detailed settlement was also ordered to be introduced into Grobogan, Djipang and Wirosari, but this was still proceeding slowly in the early months of $1814 .^{48}$ The total assessment was 150,000 J. Rs. ${ }^{48}$

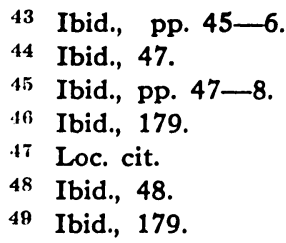


A similar settlement appears to have been ordered for Patjitan, although there is little material available on the subject. In August 1814 , the assessment of the district was stated to be 3,148 J. Rs., ${ }^{50}$ which was slightly less than that established by Crawfurd. ${ }^{51}$

\section{Semarang, Kendal and Demak.}

Raffles returned to Semarang after his visit to Kedu. The Resident, Lieutenant-Colonel Eales, had found many difficulties confronting him in the introduction of the land rent system, and Raffles spent a great part of December there attempting to bring some sort of order into the "mixed" settlement. Because of the Military Establishment at Semarang, heavy demands were made on the Javanese for public service, and this factor, together with difficulty of securing accurate information on the extent and nature of cultivation, ${ }^{52}$ forced Raffles to continue many of the farms operating in the town and its environs. The "rice market", "wax candles", "slaughtering cattle", "Chinese tobacco", wayang, and "vegetable shop" farms were all continued, as well as the capitation tax upon the Chinese. ${ }^{53}$ In an apologetic tone, Raffles informed Nightingall and the Java Council of the fact. ${ }^{54}$

The conditions of the above farms appear to me in many instances, frivolous and vexatious, but some of them, such as the vegetables shops, \&rc., are so intimately connected with the Police of the Town and Environs, and the general supply of necessaries, while the others bear exclusively on the Chinese population, who are not otherwise taxed, that some caution may become necessary in abolishing at once taxes and regulations, which, no doubt, originally were made with reference to the habits of the people, and which long usage may have rendered less oppressive and vexatious, than they would at first appear.

50 Report on Yogyakarta by Bauer and Addison, August 6, 1814, Raffles Collection, V, No. 4 (vi).

51 See p. 97.

52 Sub., 39. This is hard to understand as he was in possession of Knops' detailed report on Semarang. "Provisional or Abridged View of the Regency of Samarang and of its Dependancies", 1812, Mack. Coll., (Pr.), Vol. 79, No. 2; Mack. Coll., (Class), XIV, No. 25.

53 Raffles to Nightingall, November 27, 1813, Java Public Consultations, December 15, 1813. The farms were sold by public auction on December 27, 1813.

54 Loc. cit. 
The farms, he thought, would have to be revised eventually when the regulations for the Batavian Police and farms were completed ${ }^{55}$ But in the meantime, they could "be considered as a land rent payable under a different denomination, since these imposts bear principally upon agriculture and industry". ${ }^{56}$

In making the land rent settlement within the Semarang Residency, lands were leased to the heads of villages for one year, ${ }^{57}$ at a gross rental of $150,235 \mathrm{Sp}$. drs., or $330,517 \mathrm{~J} . \mathrm{Rs}^{58}$ The revenue farms were rented out at the slightly lower figure of $114,943 \mathrm{Sp}$. drs. $^{58}$ The land rent of Demak and Kendal, which was incorporated in the above assessment, amounted to $37,027 \mathrm{Sp}$. drs. and 23,527 Sp. drs. respectively. ${ }^{80}$ These sums, together with the $89,681 \mathrm{Sp}$. drs. established for Semarang, ${ }^{61}$ made up the gross rent of $150,235 \mathrm{Sp}$. drs. Of this, $10,000 \mathrm{Sp}$. drs., or $22,000 \mathrm{~J}$. Rs. were granted to the three Regents in compensation, ${ }^{62}$ and another 3,000 Sp. drs. were deducted as the equivalent of the rents on the lands granted to the other chiefs in the Residency. ${ }^{63} 2 \%$ of the total rent went to Eales as a commission on collections.

Raffles did not leave Semarang until December 28, when he proceeded to Djapara. He had no sooner arrived there, than news reached him of Hopkins' death at Probolinggo. Raffles hastened to the Oosthoek in order to superintend the introduction of the detailed land settlement.

\section{Pasuruan.}

Hopkins had been appointed a Commissioner for introducing the land rent system into the districts east of Bangil, but due to a con-

55 Loc. cit. Raffles hoped that the farming system would be abolished in 1815 , Sub., 39.

56 Loc. cit.

57 Loc. cit.

58 "Estimate of the probable Receipts and Disbursements of the Residency of Samarang for the year 1814", Java Public Consultations, January 17, 1814.

Compare Sub., 179. There was an augmentation of the total territorial revenue between December and February, Ibid., 40.

54 Raffles to Nightingall, December 27, 1813, Java Public Consultations, January 17, 1814.

(in "Estimate of the probable Receipts... of Samarang....", op. cit.

(i) Loc. cit.

$1: 2$ See p. 133.

63 "Estimate of the probable Receipts... of Samarang....", op. cit. Compare Sub., 179. 
fusion of orders, Pasuruan had been placed under the control of Jourdan. The latter was supposed to assist Adams at Surabaya, as well as listen to the advice of Hopkins on the subject of land rent. ${ }^{6.4}$ Raffles' instructions to Hopkins had recommended a detailed settlement of the rent in Besuki and Probolinggo, and these were also meant to apply to Pasuruan. ${ }^{65}$ When Raffles arrived in the Oosthoek early in 1814, he found that Jourdan had completed the settlement in Pasuruan, and that Hopkins' assistants were putting the finishing touches to the settlements in Probolinggo, Besuki and Banjuwangi.

In Pasuruan, Jourdan had based his assessment upon the different quality of the sawahs. He divided them into three classes, and from the best demanded one-half of the produce; from the middling two-fifths; and from the inferior one-third. ${ }^{66} \mathrm{He}$ calculated the amount of padi produced from a jung of the best sawah at between 40 and 50 hamats [amèt's]; 30 to 35 hamats from a jung of average quality sawah; and 15 to 20 hamats from inferior sawah. As the average holding of each cultivator was about one quarter of a jung, the cultivators of the best sawahs had to pay a yearly rental of $6,5 \mathrm{r} / 2$ or 5 hamats of padi; those of the middling quality sawahs from 4 to $31 / 2$ hamats; and those of the poor sawahs from 3 to 2 hamats. The value of each hamat was about $8 \mathrm{~J}$. Rs., and the cultivator was given the option of paying his rent in money or in kind. But in order to pave the way for the introduction of a money rent, it was stipulated that each cultivator had to pay the equivalent of at least 1 hamat from each quarter of a jung in cash. Jourdan thought that this was an infinitely fair arrangement. "There is little reason to fear, that this regulation will prove a source of annoyance", he informed Raffles, ${ }^{67}$ "as the collection is to be made every three months, and the demand from each individual will not exceed two Rupees per quarter." On the tegals, the rent was less. ${ }^{68}$

In Malang and Ontang [?], Jourdan was forced to establish only "a

64 De Haan, F., "Personalia", pp. 581; 589. Raffles (Sub., pp. 77-8) stated that Jourdan had been under Hopkins' orders.

(i5 Sub., 30.

66 I take these facts from Jourdan's Report, Sub., pp. 138 et seq.

G.7 Ibid., 140.

$n 8$ Loc. cit. As a general rule the tegals of the Oosthoek districts were assessed at one- third of the produce in maize when of the first quality; one-quarter if of middling quality; and one-fifth when of the poorest quality. Ibid., 138. 
moderate money assessment", ${ }^{6 \theta}$ because the expense of transporting the produce from these inland districts would have been too great, and would have reduced the amount of rent available. This "moderate" assessment was, in fact, $16 \mathrm{~J}$. Rs. per annum for each quarter jung of land..$^{70}$ Jourdan would have placed it even higher, but for the opposition from the people. ${ }^{71}$ The native people who did not possess either sawahs or tegals were required to pay a rent for the ground upon which their huts stood. This was not so much designed to add to the revenue of the Government, as to provide an incentive, for cultivation lest the people began quitting their lands. ${ }^{72}$

The total land rent of Pasuruan, Malang and Ontang was established at 530,000 J. Rs., with a tenement tax of $20,000 \mathrm{~J}$. Rs. $^{73}$

\section{Besuki, Probolinggo, Panarukan, Puger and Banjuwangi.}

After Hopkins' death, his two assistants Roxburgh and Davis continued in their positions as Collectors of the land rent in the Oosthoek districts, the former with particular jurisdiction in Besuki, and the latter in Banjuwangi. ${ }^{74}$ When he arrived at Probolinggo early in January 1814, Raffles found that they had prepared statistical tables for the introduction of the Ryotwari system. These tables gave the names of the cultivators, the amount of lands, and a calculation of the amount of rent which each cultivator was to pay, either in money or in kind. ${ }^{75}$ Hopkins thought that most of the first year's rent would be paid in kind, ${ }^{76}$ but hoped that shortly afterwards the collections would be made in cash, at an increase of $10 \% .{ }^{77}$ The first assessment of the land rent in Probolinggo, Besuki Panarukan, Puger and Lumadjang was $560,000 \mathrm{~J}$. Rs. There was also a tenement tax of $24,000 \mathrm{~J}$. Rs. ${ }^{78}$ The assessment of Banjuwangi

B8 Ibid., pp. $140-1$.

70 Ibid., 141.

71 Loc. cit.

72 Ibid., 142.

73 "Estimate of Receipts and Disbursements of the Districts East of Sourabaya ....", Java Public Consultations, January 17, 1814. Compare Jourdan's figures (Sub., 138) which suggest a lower assessment. The figure in the text accords with Raffles' estimate, Ibid., 179.

74 Sub., pp. 145-6; De Haan, F., "Personalia", pp. 635; 532-3. Davis had been appointed Resident of Banjuwangi in September 1813.

i5 Sub., 146.

76 Ibid., 147.

77 Ibid., 151.

is "Estimate of Receipts and Disbursements of the Districts East of Sourabaya....", op. cit. 
was 52,000 J. Rs. for the land rent, and another 6,000 J. Rs. for the tenement tax. ${ }^{78}$ This resulted in a total assessment of the land rent of the districts east of Surabaya of $1,192,000 \mathrm{~J}$. Rs., and a gross revenue of $1,236,000 \mathrm{~J} . \mathrm{Rs}^{80}{ }^{8}$ The disbursements were calculated at only $175,060 \mathrm{~J}$. Rs., or $14 \%$ of the total revenue, ${ }^{81}$ so that there was an estimated surplus revenue of one million J. Rs. ${ }^{82}$

\section{Surabaya and Gresik.}

Although Adams had found that the Petinggis held elective offices, ${ }^{83}$ he used the discovery to support a different conclusion from that of Raffles. Adams thought that a land rent settled on the village chiefs was "the one most suited to this division of the country, not only as it is what the people are accustomed to... but as the one in which, until a more complete knowledge of the history of the country is obtained than now exists ... is least likely to neglect those who have the best claim to preference" ${ }^{84}$ Raffles questioned this, ${ }^{85}$ but he agreed to such a settlement at Surabaya, because of the local difficulties. ${ }^{86}$ The farming system was continued, and the profits from this, and the land rent, were expected to yield an increase in the territorial revenue of $567,178 \mathrm{~J}$. Rs. ${ }^{87}$ The gross assessment of the land rent was established at $605,404 \mathrm{~J}$. Rs. After allowing a deduction of $72,302 \mathrm{~J}$. Rs. as compensation for the chiefs, ${ }^{88}$ a net land rent of $533,102 \mathrm{~J}$. Rs. was anticipated. ${ }^{89}$

\section{Rembang, Lasem and Tuban.}

Raffles did not include Rembang, Lasem and Tuban in the arrangements which had been made in August and September 1813. In his Minute of September 17 he simply stated that these districts would, together with Blora, form a central Blandongs district. ${ }^{90}$

79 Loc. cit.

80 Raffles to Nightingall, January 10, 1814, Java Public Consultations, January 17, 1814. Compare Sub., 179.

81 Raffles to Nightingall, Ibid.

82 Sub., 43.

\$3 Ibid., pp. $117-8$.

84 Ibid., pp. $118-9$.

85 Ibid., 42.

80 Loc. cit.

87 Loc. cit.

\&8 Compare p. 138.

89 Sub., 179.

H1) Deventer, M. L. van, N.G., 23. 
However, instructions were issued to Hopkins shortly afterwards to introduce a detailed settlement there. ${ }^{91}$ The settlement was far enough advanced by January for Raffles to include Rembang, Lasem and Tuban among the districts where the detailed system had already been introduced. He wrote to Nightingall on January $10:{ }^{22}$

[Besuki, Probolinggo, Pasuruan and Banjuwangi] are the only Districts which have as yet been settled according to the detailed system by which an arrangement is made with each cultivator in the village, but a similar settlement is now in progress in the Cadoe and the other Districts lately ceded to Government, and [in] Rembang, Lassum and Touban, and I have reason to calculate on the most favourable results to the Public Revenue, at the same time that the rights and interests of each individual will be more effectually protected.

By the middle of the following month, Raffles thought that Davidson's ${ }^{83}$ settlement of the districts would produce a total revenue of $256,092 \mathrm{~J}$. Rs., or an increase of $150,000 \mathrm{~J}$. Rs. on its previous revenue. ${ }^{94}$ The net land rent was estimated at 228,868 J. Rs. ${ }^{95}$

Djapara, Djuwana, Pati and Kudus.

Raffles had been called away from Djapara at the end of December because of Hopkins' sudden death at Probolinggo. In the meantime, McQuoid had made a settlement on the village chiefs for one year. ${ }^{9 h}$ The assessment of the land rent for the Djapara-Djuwana districts was as follows: ${ }^{87}$

$$
\begin{aligned}
& \text { Djapara . . . . . . . } 19,825 \text { Sp. drs. }(43,615 \text { J. Rs.) } \\
& \text { Djuwana . . . . . . } 21,789 \text { Sp. drs. (47,935 J. Rs.) } \\
& \text { Kudus . . . . . . . 14,724 Sp. drs. (32,392 J. Rs.) } \\
& \text { Pati . . . . . . . 48,039 Sp. drs. }(105,685 \text { J. Rs.) }
\end{aligned}
$$

91 Sub., 41.

92 Raffles to Nightingall, January 10, 1814. Java Public Consultations, January $17,1814$.

93 De Haan, F., "Personalia", 531.

84 Sub., 42.

95 Ibid., 179.

96 Ibid., 40.

97 "Estimate of Receipts and Disbursements of the Residency of Japara... for the year 1814", Java Public Consultations, February 3, 1814. 
There was also a tenement tax which amounted to $14,000 \mathrm{Sp}$. drs. The total land revenue was thus $118,379 \mathrm{Sp}$. drs., or $260,433 \mathrm{~J} . \mathrm{Rs}^{98}$ From this, 16,336 Sp. drs., or $35,939 \mathrm{~J}$. Rs. had to be deducted as the amount of compensation paid to the Regents and chiefs. ${ }^{98}$ McQuoid's estimate of the total net revenue of the Djapara Resi dency was, therefore, too high. ${ }^{100}$ However, he saw other than financial benefits in the new revenue system. He told Raffles that the "advantages of still greater importance, and more highly to be prized by every enlightened, liberal, and just Government, are the genuine attendants on this system of revenue, since it may be truly said to carry in its train, directly to the cultivator of the soil, the inestimable blessings of emancipation from thraldom and exactions of those bloodsuckers who formerly beset him in all directions, a freedom to exert his best energies for his own individual benefit, an adequate payment for labour, whether given for public or private purposes, and the greatest possible stimulus to industry, [and] security of property"..101

With such high flown phrases ringing in his ears, Raffles returned to Batavia. He arrived there on January 28 , and began a feverish preparation of his despatches for Europe and Bengal. By February 11, he had written his long land rent Minute, and completed the revenue and judicial regulations for the introduction of the new system. ${ }^{112}$ Truly a remarkable effort.

98 Loc. cit. Compare Sub., 179.

48 "Estimate of Receipts... of Japara....", op. cit. See p. 135, and compare Sub., 179.

100 Sub., 40.

101 Ibid., pp. 40-1.

102 All printed in Sub. 


\section{IDEAS AND REACTIONS}

\section{Raffles' Revenue Instructions.}

It is unnecessary here to examine in any great detail Raffles' revenue instructions of February $11,1814 .{ }^{1}$ Levyssohn Norman, who was most critical of the land rent system in general, has given a good summary of them, and they have been translated into Dutch. ${ }^{2}$ The instructions were based upon the principle that the Government would act "directly with each individual cultivator", and would stand forth as "the sole Collector and enjoyer of its own revenues". 3 In theory, the revenue administration was to be separated from the judicial branches of Government by the appointment of Collectors. These officers were to supervise the working of the land rent system, and relieve the Residents from any additional burdens which the new system might impose. ${ }^{4}$ In practice, the Residents continued to control the collection and administration of the land rent. Very few Collectors were ever appointed. ${ }^{5}$

Raffles' instructions stated that the land rent was to be collected by the heads of the villages. ${ }^{b}$ There was thus only a theoretical distinction between the village and the Ryotwari systems. In the case of the former, lands were leased or rented to the village headmen, who collected the rent from the cultivators. In the detailed settlement, the village chiefs continued to collect the rent, but they did so not by any right of lease, but on the orders of the Government. ${ }^{7}$ Raffles thought that the new system possessed all the advant-

1 Sub., pp. 181 et seq.

2 Deventer, S. van, L.S., I, pp. 102 et seq.; Anon., Extract-Vertalind cener Memorie, van Thomas Stamford Raffles... den 11 Februarij 1814, (1828).

3 Sub., 194.

4 Ibid., 181.

5 The names of few Collectors appear in the Java Almanac for the years 1814 and 1815. See Norman, H. D. Levyssohn, op. cit., 193.

( Sub., 184.

7 Notice, however, Raffles' curious use of the word "lease", Ibid., 197. A copy of the certificates issued to the village headmen under the detailed settlement is printed Ibid., pp. $212-3$. 
ages of the village settlement, with none of its evils. ${ }^{s}$ The village headmen were to be paid either in cash, or by exempting them from the payment of rent on their own lands.

In order that the detailed system might function properly, the "minutest details" ${ }^{9}$ regarding the lands and their produce were necessary. The Collectors were to gather this information from the "head inhabitants" of the villages in their divisions, or by conducting an investigation themselves. ${ }^{10} \mathrm{~A}$ detailed survey of Java would thereby result. ${ }^{11}$ On the basis of this information a regular and just settlement of the land rent was to be made, not upon the village chiefs, but upon the individual cultivators. ${ }^{12}$ The rents were to be calculated as follows: ${ }^{13}$

$\begin{array}{lcc} & \begin{array}{c}\text { Sawahs } \\ \text { produce }\end{array} & \begin{array}{c}\text { Tegals } \\ \text { produce }\end{array} \\ \text { Best quality } & 1 / 2 & 2 / 5 \\ \text { Middling quality } & 2 / 5 & 1 / 3 \\ \text { Poor quality } & 1 / 3 & 1 / 4\end{array}$

In estimating the produce of the various lands, the average of former years was to be taken as the criterion. ${ }^{14}$ The produce of the sawahs was to be calculated in rice, and that of the tegals in maize. The above rates were to be the maximum amounts demanded, but Raffles thought that these would probably not be realized immediately. ${ }^{15}$ The cultivators, despite the fact that few of them could read or write, were to be given written statements of the amount of lands they held, and the rent that was to be demanded of them. ${ }^{16}$ This was supposed to protect them against the extortions and malpractices of the village chiefs. ${ }^{17}$ Rents were to be paid either in kind or in money. Raffles stated that the option had been left to the cultivators because of the scarcity of specie in the island.$^{18}$ But this option was only to apply to the cultivators of the sawahs, who could,

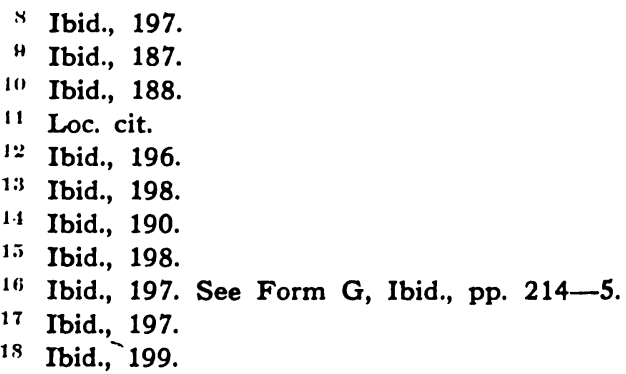


if they wished, deliver rice in payment of their rents. The farmers who produced maize from tegals were not so fortunate. They had to find money for their crop in order to pay the Government its dues. ${ }^{19}$ Thus while admitting the great shortage of specie in the island, Raffles nevertheless demanded it from the very cultivators who could ill afford to risk speculations on their crops.

Levyssohn Norman criticized the instructions which Raffles issued for the introduction of the detailed settlement of the land rent in Java, mainly on the grounds that they did not contain one administrative provision for the working of such a sweeping reform. ${ }^{20}$ There were, in fact, too many provisions for the working of the system, provisions which could only, and perhaps doubtfully, have been applied with the administrative machinery of a modern colonial Government. Not only was this machinery lacking in Raffles' time, but he did not have a dozen civil servants who he could have appointed to the posts of Collectors of the land rent. The detailed system remained a village system in fact.

\section{Bengal's reaction to Raffles' Reforms.}

While Raffles was engaged in writing his Minute, he received a private letter from his patron, Lord Minto, who was then preparing for his departure to England. Minto had written before he had received Raffles' Minute of September, or the documents relating to the introduction of the village settlements along the North East coast. ${ }^{21} \mathrm{He}$ was, however, in possession of Raffles' June Minute. In his farewell letter, ${ }^{22}$ Minto reluctantly approved the sale of lands, although he thought that it was too important a measure for a provisional Government to have undertaken without reference. He continued

[A]lthough my views, as you know, lead to the transfer of public territory to the management of individual industry,

20 Norman, H. D. Levyssohn, op. cit., 192.

21 In a Minute recorded on June 18, 1814, (Java, Vol. 63) Edmonstone stated that Raffles' despatch of October 5, 1813, (Bengal Civil Colonial Consultations, February 15, 1814) which contained the Minute of September 17, 1813 , as well as the instructions issued to the Residents at this time, did not reach Bengal until December 10, 1813. There was a further delay in circulating it among the members of the Council. 
and the creation of a genuine landed interest, with all its immediate benefits and ameliorating tendencies, in the room of the deplorable system of vassalage and dependence under which land is now held in Java; yet I have felt that this change could not be brought about suddenly, partly from the very nature of all extensive changes, partly from the circumstances of the colony, which contains at present neither capital nor capitalists enough to afford a comparison between the value in the market, of land and money, either fair or at all approaching to be fair. I should have inclined, therefore, to small and partial sales of land, if alienation in perpetuity should have been thought advisable at all, proportioned in some degree to the disposable quantity of money in the hands of individuals. But the general course to be recommended I conceive to be short leases, followed by longer, and ultimately by perpetuities.

Minto went on to warn Raffles against the adoption of a permanent settlement. He said this might later be annulled by the authorities in London.

Raffles replied confidently two days after he had put the finishing touches to his Minute of February 11. He told Minto of his surprise when he learned from a copy of the Fifth Report, which had just fallen into his hands, that he had hit upon the principles of the Ryotwari settlement by accident. "I have throughout", he continued, "considered myself as the agent acting under your Lordship's instructions; and I can assure you that my ambition will be gratified by an assurance that I have not failed in acting up to your original design". ${ }^{23}$ This statement alone makes nonsense of Wright's contention that Raffles was acting secretively in not making known his intentions before Minto left Bengal. ${ }^{24}$ His despatch of October 5, 1813 , contained full information on the settlements which were then in progress, and we must admit a fair degree of duplicity in Raffles' character if we question the sincerity of the above passage. The truth of the matter seems to be that although he had visited Bengal, Raffles knew little of the details of the revenue systems of British India, nor of the conflicts between the Madras and Bengal Governments concerning them. He believed that the Ryotwari settlement was quite compatible with Minto's original instructions which had never been amplified. Indeed, Minto may well have left them vague because of other considerations.

23 Raffles to Minto, February 13, 1814, Ibid., 224.

24 Wright, H. R. C., "Muntinghe's Advice to Raffles....", op cit., 245. 
The Bengal Government under Minto's Governor-Generalship strongly supported a permanent Zamindari system of revenue collection, at a time when the Madras settlements were receiving praise at home. But if, as it has been argued, Minto wished to extend the Zamindari system to Java, he did not consider that the Regents would necessarily act as Zamindars. One cannot read his instructions to Raffles which recommended "a fundamental change in the whole system of landed property and tenure" ${ }^{25}$ without realizing that he meant that the Regents should be dispensed with in the collection of revenue. Raffles' own instructions to the Mackenzie Commission, which undoubtedly reflected Minto's views, specifically raised the question of the removal of the Regents from effective control over the lands. Thus, although a settlement with a Zamindari flavour was hinted at, it is clear that the Zamindars were to be found lower down in the native hierarchy. ${ }^{26}$ One of the strangest features of the whole problem was that Minto did not tell his colleagues on the Bengal Council about the instructions which he had left for Raffles, until he was on the point of leaving Calcutta for London. ${ }^{27}$ Yet he had placed before them the other documents which related to the establishment of the Java Government when he had returned to India at the end of 1811. Minto also withheld the instructions from the Directors of the Company. ${ }^{28}$ The most likely explanation to account for this secrecy was that Minto realized that in advocating the removal of the Regents, he would have aroused opposition, particularly in the Council. Although he supported the Bengal system of revenue collection, Minto was by no means uncritical of the Zamindars. "The zemindars, or gentlemen of landed property", he wrote to his wife in $1809,{ }^{28}$ "have very commonly no other idea of an estate than as a field to plunder in, nor of the influence which property gives, than as a power to extort and pillage amongst the people subject to them". In Java he was not prepared to allow the continuation of such exploitation by the Regents, and so suggested their removal.

When Raffles' reforms were reviewed by the Supreme Govern-

Minute by Minto, August 3, 1813, Bengal Civil Colonial Consultations, August 16, 1813.

28

29

Minto to Raffles, February 26, 1812, Raffles Collection, I, No. 14.

Minto, Countess of, Lord Minto in India, (1880), 187. 
ment early in 1814, the general objections expressed against them were firstly, that the land rent system had been introduced too suddenly, and secondly, that the Regents had been set aside without due consideration of their rank and dignity. The members of the Supreme Government thought that it would have been better if the Regents had been utilized in the collection of revenue. They considered that the reforms had been too sweeping, particularly when "the nature of Tenures, [and] the rights of Individuals in the soil" was so imperfect. ${ }^{30}$ But when Muntinghe had rallied to Raffles' defence concerning the wisdom of dispensing with the services of the Regents in the revenue administration, ${ }^{31}$ and Minto's instructions were reconsidered, the hostility of the Supreme Government to the reforms began to wane. In June, Edmonstone admitted that it would have been impossible for Raffles to have carried out the reforms intended by Minto "without a diminution of the authority of the Regents". ${ }^{32}$ But at this time, and for some months afterwards, the Supreme Government was under the impression that the village system of revenue collection was in operation in Java. This suggests that Raffles' Minute of February did not receive the careful perusal that it deserved.

\section{Raffles defends the new System.}

On October 6, Raffles informed Bengal of the misconception which had arisen concerning his intentions. ${ }^{33}$

The village mode of settlement we have ever decidedly pronounced not to be in our opinion the most advantageous, and we have always represented our having resorted to it in many districts entirely as an intermediate step, as a measure in some places thought necessary for that gradual process of introduction which on so many accounts appeared most advisable. But we did always state that it was not to be considered as an ultimate measure, but merely as a link which expediency recommended to be placed between the feudal system before existing, and the detailed settlement which it was from the

30 Tucker to Assey, January 15, 1814, Java, Vol. 69. The despatch is printed in Deventer, M. L. van, N.G., pp. 27-O.

31 Muntinghe to Raffles, March 20, [1814], Enclosure No.20, Gillespie Charges, pp. $39-40$.

32 Minute by N. B. Edmonstone, June 18, 1814, Java, Vol. 63. Italics mine.

33 Raffles to Nugent, October 6, 1814, Java, Vol. 70. 
very commencement our most determined wish to introduce at as early a period as practicable.

He regretted that the Supreme Government had not subjected his proposals to more constructive criticism "because we are of opinion that it is still in its every part open to revision, and it was particularly to retain it so, and in the anxious hope that the Government of Bengal would have thoroughly canvassed the principles of the plan, and the measures which have been pursued in the course of carrying it into execution, ... that we determined on making that Settlement only for the period of one year". ${ }^{34}$

Raffles often claimed that his proposals for the detailed settlement of the land rent, contained in his Minute of February 11, were open to revision. ${ }^{35} \mathrm{He}$ seems to have been sincere in believing this. In any case there was ample time for the Indian authorities to have expressed their disapproval of the extension of the detailed system throughout the coastal districts of Java, before that system was actually introduced. For what is not always realized is that there was a lapse of at least a year after Raffles had completed his Minute of February 1814, before the Ryotwari settlements were completed, and it was not until May 1815 that any regular assessment took place. But while admitting his willingness to consider criticism of the detailed system, Raffles believed that the principles enunciated in February would require few modifications. He had met the criticism of the Supreme Government concerning the hasty introduction of the land rent system when little was known about the land tenures of the island, by stating that he intended to continue research into the matter. But, he continued," "we remain ... of opinion ... that our general outline of the nature of these Tenures as given in our former despatches, and the principles assumed respecting them as the basis of our settlements, will not be found to have been either prematurely or erroneously drawn. The leading features of Javanese proprietary rights were, we think, sufficiently ascertained, and as to the minor modifications of it found to exist in some places, we have taken particular care to have them paid the most scrupulous attention to, wherever they have been satisfactorily ascertained".

34 Loc. cit.

35 Loc. cit.; Sub., 171; Gillespie Charges, 164.

36 Raffles to Nugent, October 6, 1814, op. cit. 
The present study is not concerned with the working of the land rent system during Raffles' administration, but with his ideas during the years 1811-14. Although it would be wrong to suggest that after 1814 those ideas remained static, it is nevertheless true that by then he had arrived at fairly firm and consistent principles which he wished to apply. The year 1814, therefore, forms a convenient dividing line in the history of the land rent system under the British administration. During that year, to be sure, there were occasions when Raffles paused to consider the exaggerated claims which he had advanced in favour of the new revenue system, but they were rare. However, in July he had written to Bauer, the Accountant-General, who had been appointed to investigate the working of the system in the Eastern Districts: ${ }^{38}$

The principles of an entire new System of Political Economy have been introduced throughout Java since the establishment of the British Government. These principles are, I believe, generally known, and they require no sooner to be known than to be approved of; abstractly their results may be calculated upon from the immutable principles of human nature, and eventual success cannot be doubted. But in bringing them into practice, and giving them a fair trial, much must depend upon details, and from a want of attention to them in the first instance the best Systems in the world might fail. I took myself personally to establish and indeed, practically to apply these principles, and the Residents have done much in completing the detail, but several of them have unfortunately been removed and transferred from one station to another, and at all events, the finishing stroke of the details becomes necessary. This important object I confide in a great measure to your talents, judgement and integrity, and I have full confidence in the accomplishment of all I can wish.

In the course of arranging these details, you will necessarily. obtain much information regarding the real state of the country. In the estimates I have made of the advantages of the new System over that which has been exploded, I may perhaps from being the founder of the new System, and perhaps from National feeling have been led to judge too favourably of what

The land rent system was not introduced into the Priangan Regencies or into the Blandongs. See Day, C., op. cit., pp. 189-90; Norman, H. D. Levyssohn, op. cit., pp. $161-4$.

Raffles to Bauer, July 1, 1814, Raffles Collection, V, No. 3. Italics mine. 
But it is an exaggeration to argue, as one Dutch historian has done, ${ }^{39}$ that the reason why Raffles did not extend the land rent system to the Priangan was because he "lacked faith in his own system".

Writing after he had left Java, Raffles declared that he had been on the point of introducing free cultivation into the Batavian and Priangan Regencies, but that the cession of Java to the Dutch had prevented him. ${ }^{40}$ There is, perhaps, some truth in this statement. In February 1814 he had announced his intention of making a detailed settlement in the Regencies. "The introduction of the detailed system of management in the Batavian Regencies", he wrote, ${ }^{41}$ "seems alone capable of affording the means of ascertaining the actual amount of territorial revenue, foregone in favour of the coffee delivery; and on this account, as well as to define the rights and duties of individuals, and to afford that spur to industry and exertion, so long wanting on this Island, I consider such a measure in these districts indispensable". And yet Raffles hesitated about its introduction until it was too late. Why?

Part of the answer to this question is to be found in the charges which Gillespie directed against his administration. Raffles had stated that he intended to introduce free cultivation into the Priangan in February 1814. At the end of that month he learnt of the Gillespie-Blagrave charges. They placed Raffles in a dilemma. On the one hand, he wished to extend the principles of free trade throughout the Company's domains in Java; on the other, he had to defend himself against Gillespie's charge that the sale of coffee gardens in the Batavian-Priangan Regencies had placed a valuable export commodity in the hands of private individuals, and so had destroyed the Government's monopoly of the product. ${ }^{42}$ Raffles' obvious defence was to deny that the monopoly had been affected either by the sales of lands, or by the introduction of free cultivation in the coffee gardens in the Eastern Districts of the island. The Government's object, he stated, ${ }^{43}$ had been "to maintain such extent

\footnotetext{
Klaveren, J. J. van, op. cit., 92.

$H$. of J., I, 130.

Sub., pp. 67-8.

Gillespie Charges, 49.

Ibid., 78.
} 
of Monopoly as would secure the utmost quantity of Coffee which could be demanded, without continuing that extensive cultivation and produce of the article, the purchase of which was unprofitable, and beyond the reach of the Public Finances". He denied that the private sales in the Priangan and Batavian Regencies had in the least affected the Government's monopoly of coffee. ${ }^{44}$ Thus because of the pressure of events, Raffles had to postpone admitting the principles of free cultivation into the Regencies. He was apparently supported in this position by McQuoid, who was opposed to the abolition of forced cultivation on the coffee gardens. Crawfurd wrote to Baud in 1858: ${ }^{45}$

He [Raffles] abolished the coffee monopoly, preserving it in the Preangan Regencies very inconsistently. I remonstrated with him on the subject, but the Resident of the Preangan Regencies at that time, a Mr. Macquoid, carried it against me. The reservation of this part of the monopoly was a subject of regret afterwards to Raffles himself as he often told me.

Even when he was defending himself against the Gillespie charges, Raffles was inclined to be embarrassed by the exception allowed in the Priangan to the general principles of free trade and cultivation. He attempted to rationalize it by pointing out the difference between the Sundanese and the Javanese. ${ }^{46}$

Raffles, of course, set high hopes on a large peace-time disposal of coffee ${ }^{47}$ both in the European and American markets. But there is no evidence to suggest that he continued the system of forced cultivation in the Priangan because he thought that production would have declined under a system of free cultivation. In 1817 he stated his belief that the amount of coffee produced under the latter system would not have been less than under the former. ${ }^{48}$ This opinion, of course, was expressed after he had surrendered his position as Lieutenant-Governor of Java. But it was quite consistent with his views after 1814. That it was unrealistic in ignoring the aversion of the Sundanese to the coffee cultivation must, however, be admitted.

Ibid., pp. $78-9$.

Crawfurd to Baud, January 9, 1858, Baud Collection, (Rijksarchief), No. 889.

Gillespie Charges, 159.

See Norman, H. D. Levyssohn, op. cit., 241. See p. 144 above.

H. of J., I, 130. 
There was another factor which gives support to Raffles' contention that it was the cession of Java to the Dutch which prevented him from extending the benefits of the revenue system to the Priangan and Batavian Regencies. This was that his attention had been fully occupied after August 1814 with the introduction of the detailed settlements into the Eastern Districts of Java. It was not until the middle of the following year that any regular assessments were made, and not until August of that year was it possible for him to turn his attention to the Priangan. By then, of course, the news of the restoration of the island to the Dutch had been received, and Raffles knew that his time as Lieutenant-Governor was limited. Should he have commenced a hasty introduction of the detailed system into the Priangan at that date? The Dutch can be thankful that he did not. 


\section{BIBLIOGRAPHY}

\section{Manuscript Sources}

\section{(a) INDIA OFFICE LIBRARY, LONDON.}

Bengal Civil Colonial Consultations, Range 167, Vols. 33-61.

Bencal Letters Received, Vols. 61, 66.

Bengal Political Letters Received, Vol. 10.

Bengal Secret Letters, Vol. 13.

Board's Drafts of Secret Letters to India, Vol. 5.

Correspondence between Court of Directors \& Board of Commissioners for India, Vol. 3.

Despatches to Bengal, Vol. 58.

Java Factory Records, Vols. 13-71.

Vols. 15-29 are cited as Java Public Consultations.

Vols. 30-36 " , "Java Military Consultations.

Vols. 37-39 " " "Java Separate Department Proceodings.

Vols. 43-71 ", "Java.

Mackenzie Collections: (The titles of the various documents are cited fully in the footnotes).

(i) Private - Vols. 7, Nos. 1, 2; 13, Nos. 6, 7, 8, 9, 10, 11, 12, 17 (b), 17 (c); 14, Nos. 15 (b), 16 (iv); 21 , Nos. 4, 5, 6, 7, 8, 9, 10; 24, Nos. 1, 2, 3; 26, Nos. 3, 4; 35, Nos. $1,2,3,4,6,13,18,19,20,21,22$; 38, No. 2 ; 56 ; 74 , Nos. $42,50,52,53,55 ; 79$, No. 2 .

(ii) Class - Vol. XIV, Nos. 6-8, 25.

(iii) Miscellaneous - cited fully in footnotes.

Raffles Collection: (Eur. Mss. (Minor Collections), 232 et seq.).

Vols. I, Nos. 14, 15; II, No. 8; III, No. 21; V, Nos. 3, 4(i), 4 (ii), 4 (iii), 4 (vi), 4 (xi).

\section{(b) BRITISH MUSEUM, LONDON.}

"Papers relating to Java, circa 1815", Add. Mss., 30, 353.

"J. Crawfurd, Papers on Java, Cochin China etc., 1811-1823", Add. Mss., 33, 411.

(c) ALGEMEEN RIJKSARCHIEF, THE HAGUE.

Baud Collection, Nos. 889; $1,002$.

\section{(d) PRIVATE.}

The Journal of T. O. Travers - in manuscript. The Journal is in the possession of Mr. M. T. L. Travers of Dublin, Ireland. I have read a typewritten transcript in the possession of the late C. E. Wurtzburg. 


\section{Printed Sources}

(i) Bibliographical:

An Annotated Bibliography on Land Tenure in the British and British Protocted Territories in South East Asia and the Pacific, (H.M.S.O., London, 1952), Colonial Research Studies, No. 6.

Blagden, C. O., Catalogue of Manuscripts in European Languages bolonging to the Library of the India Office. The Mackenzie Collections, (Oxford University Press, 1916), Vol. 1, Part I.

Kaye, G. B., and Johnston, E. H., Catalogue of Manuscripts in European Languases, India Office Library. Minor Collections and Miscollanoous Manuscripts, (H.M.S.O., London, 1937), Vol. II, Part II.

(ii) Official:

Java Government Gazette, (Batavia), February 29, 1812-1816.

Proclamations, Regulations, Advertisements, and Orders, printed and published in the Island of Java, by the British Government, under its Authority, (Batavia, 1813, 1816), 2 vols, September 1811-September 1815.

Selection of Papers from the Records at East-India House, relating to the Revenue, Police, and Civil and Criminal Justice, under the Company's Governments in India, (London, 1820), Vol. I.

The Java Annual Directory and Almanac, for 1814 and 1815, (Batavia, 1814, 1815).

(iii) Books :

[Addison, G. A.,] Original Familiar Correspondence between Residents in India including Sketches of Java etc. etc., (Edinburgh, 1846).

Anon., Extract-Vertaling oener Memorie, van Thomas Stamford Raffles... don 11 Februarij 1814....., (Amsterdam, 1828).

Anon., Official and Secret Papers Relating to the Sale of Lands and Other Subjects During the British Administration of Java, (The Hague, 1883, privately printed).

Arbuthnot, Sir A., Major-General Sir Thomas Munro: Seloctions from his Minutes and other Official Writings, (London, 1881), 2 vols.

Ascoli, F. D., Early Revenue History of Bengal and the Fifth Report, 1812, (Oxford University Press, 1917).

[Assey, C.,] Review of the Administration, Value, and State of the Colony of Java with its Dependencies, As it was, - As it is, - and as it may be, (London, 1816).

Baden-Powell, B. H., The Land-Systems of British India, (Oxford University Press, 1892), 3 vols.

- A Short Account of the Land Revenue and its Administration in British India; with a Sketch of the Land Tenures, (Oxford University Press, 1907).

Bergsma, W. B., Eindresumé Onderzoek naar de Rechten van den Inlander op den Grond op Java en Madoera, (Batavia, 1876-96), 3 vols.

Boeke, J. H., The Evolution of the Netherlands Indies Economy, (New York, 1946).

Boulger, D. C., The Life of Sir Stamford Raffles, (London, 1899), Second edition. 
Boys, H. S., Some Notes on Java and its Administration by the Dutch, (Allahabad, 1892).

Bradshaw, J., Sir Thomas Munro and the British Settlement of the Madras Presidency, (Oxford University Press, 1894).

Burger, D. H., De Ontsluiting van Java's Binnenland voor het Wereld Verkoor, (Wageningen, 1939).

Campbell, D. M., Java: Past \& Present, (London, 1915), 2 vols.

Colebrooke, H. T., Remarks on the Husbandry and Internal Commerce of Bengal, (London, 1806), second edition.

Colenbrander, H. T., Koloniale Geschiedenis, ('s-Gravenhage, 1925-6), 3 vols.

Coupland, Sir R., Raffles of Singapore, (London, 1946). Earlier editions were published by the Oxford University Press, $1926 \& 1934$.

Crawfurd, J., History of the Indian Archipelago, (Edinburgh, 1820), 3 vols.

-, A Descriptive Dictionary of the Indian Islands \& Adjacont Countrier. (London, 1856).

Daendels, H. W., Staat der Nederlandsche Oostindische Bezittingen, onder het Bestuur van den Gouverneur-Generaal Herman Willem Daendels, Ridder, Luitenant-Generaal, \&c. in de jaren 1808-1811, ('s-Gravenhage, 1814), 1 vol. + 3 Bijlagen.

Day, C., The Policy and Administration of the Dutch in Java, (New York, 1904).

Deventer M. L. van, Het Nederlandsch Gezag over Java en Onderhoorighoden sedert 1811, ('s-Gravenhage, 1891), Vol. 1. (Volume II was never published).

- Daendels-Raffles, $A$ Dissertation on the Two Celebrated Governors of Java, (London, 1894), Translated by G. G. Batten.

Doventer, S. van, Bijdragen tot de kennis van het Landelijk Stelsel op Java, (Zalt-Bommel, 1865-6), 3 vols.

Dictionary of National Biography, (London, 1893), Vol. XXXV.

Dodwell, H. H., edit. The Cambridge History of India, (Cambridge University Press, 1929), Vol. V.

Egerton, H. E., Sir Stamford Raffles: England in the Far East, (London, 1900). Emerson, R., Malayasia: A Study in Direct and Indirect Rule, (New York, 1937).

Encyclopaodie van Nederlandsch-Indië, ('s-Gravenhage and Leiden, 1895-1905), 4 vols.

Second edition, ('s-Gravenhage and Leiden, 1917-1939), 4 vols. + 4 supplementary vols.

Unless indicated, all references in the text are to the first edition.

Feldmann, N. J., De Overheidsmiddelen van Indonesië in verband met de Dualistische Economie, (Leiden, 1949).

Firminger, W. K., The Fifth Report from the Select Committee of the House of Commons on the Affairs of the East India Company, (Calcutta, 1917-8), 3 vols.

Furnivall, J. S., Studies in the Economic and Social Development of the Notherlands East Indies: An Introductory Survey, 1815-1930, Part I, (Rangoon, 1933).

-, Notherlands India: A Study of Plural Economy, (Cambridge University Press, 1944).

Gelpke, J. H. F. Sollewijn, De Landerijen onder het Engelsche Tusschenbestuur Verkocht en het Verbod van Heerendiensten aldaar, (1889, privately printed). , Gegevens voor een nieuwe Landrente-Regeling - Eindresumé der ondorzoekingen bevolen bij Gouvts.besluit van 23 Oct. 1879, No. 3, (Batavia, 1885).

Gillospie Charges (see List of Abbreviations). 
Gleig, G. R., The Life of Major-General Sir Thomas Munro...., (London, 1830), 3 vols.

Gonggrijp, G., Schets eener Economische Geschiedenis van Noderlandsch-Indië, (Haarlem, 1928).

Gopal, S., The Permanent Settlement in Bengal and its Results, (London, 1949).

Graaf, H. J. de, Geschiedenis van Indonesië, ('s-Gravenhage/Bandung, 1949).

De Haan, F., Priangan, De Preanger-Regentschappen onder het Nodorlandsch Bestuur tot 1811, (Batavia, 1910-12), 4 vols.

Haar, B. ter, Adat Law in Indonesia, (New York, 1948), translated by Hoebel, E. A. \& Schiller, A. A.

Hahn, E., Raffles of Singapore: A Biography, (London, 1948).

Harington, J. H., An Elementary Analysis of the Laws and Regulations enacted by the Governor General in Council, at Fort William in Bengal, (Calcutta, 1814-15), Vol. II.

Hogendorp, D. van, Berigt van den tegenwoordigen toestand der Bataafsche Bezittingen in Oost-Indiën en den Handel op Dezelve, (Delft, 1799).

- "Schets of Proeve, over den tegenwoordigen staat van Java, en ontwerp tot verbetering van dies bestier", (1799 ?), Eindresumé, II, Bijlage LL, pp. $152-6$.

- Stukken raakende de tegenwoordigen toestand der Bataafsche Bezittingen in Oost-Indië en den Handel op dezelve, (Delft and Den Haagse, 1801).

Jonge, J. K. J. de, De Opkomst van het Nederlandsch Gezag in Oost-Indië, ('s-Gravenhage, 1888), Vol. XIII.

Kat Angelino, A. D. A. de, Colonial Policy, (New York, 1931), 2 vols.

Kaye, J. W., The Administration of the East India Company: A History of Indian Progress, (London, 1853).

Keith, A. B., Speeches \& Documents on Indian Policy 1750-1921, (Oxford University Press, 1922), Vol. 1.

Kemp, P. H. van der, Java's Landelijk Stelsel 1817-1819, ('s-Gravenhage, 1916).

Klaveren, J. J. van, The Dutch Colonial System in the East Indies, (The Hague, 1953).

Klerck, E. S. de, History of the Netherlands East Indies, (Rotterdam, 1938), 2 vols.

Mackenzie, W. C., Colonel Colin Mackenzie, First Surveyor-General of India, (Edinburgh and London, 1952).

Mijer, P., Verzameling van Instructien, Ordonnancien en Reglementen voor do Regering van Noderlandsch Indie, (Batavia, 1848).

Minto, Countess of, Life and Letters of Sir Gilbert Elliot, First Earl of Minto from 1751 to 1806, (London, 1874), 3 vols.

Minto, Countess of, Lord Minto in India, Life and Letters of Gilbert Elliot, First Earl of Minto from 1807 to 1814, (London, 1880).

Money, J. B., Java; or, How to Manage a Colony, (London, 1861), 2 vols.

Muir, R., The Making of British India 1756-1858, (Manchester University Press, 1923).

Norman, H. D. Levyssohn, De Britsche Heerschappij over Java en Onderhooricheden, (1811-1816), ('s-Gravenhage, 1857).

Ottow, S. J., De Oorsprong der Conservatieve Richting, (Utrecht, 1937).

Paske-Smith, M., Report on Japan to the Secret Committee of the English East India Company, 1812-1816, (Kobe, Japan, 1929).

Philips, C. H., The East India Company 1784-1834, (Manchester University Press, 1940). 
Platteel, P. J., De Grondslagen der Constitutie van Nedorlandsch-Indië, (Utrecht, 1936).

Raffles, T. S., Substance of Minute recorded by the Honourable Thomas Raffles, Lieutenant-Governor of Java and its Dependencies, on the 11th Fobruary 1814; on the Introduction of an Improved System of Internal Management and the Establishment of a Land Rental on the Island of Java ...., (London, 1814).

, History of Java, (London, 1817), 2 vols.

- Statement of the Services of Sir Stamford Raffles, (London, 1824).

Raffles, Lady Sophia, Memoir of the Life and Public Services of Sir Thomas Stamford Raffles, F. R. S. \&sc., (London, 1830).

Ramsbotham, R. B., Studies in the Land Revenue History of Bengal 1769-1787, (Oxford University Press, 1926).

Ruthnaswamy, M., Some Influences that made the British Administrative System in India, (London, 1939).

Schoute, D., Occidental Therapeutics in the Netherlands East Indies during throe Centuries of Netherlands Settlement 1600-1900, (Batavia, 1937).

Schoutendorp, J., Schets van de Geschiedenis der Landrente op Java, (Amsterdam, 1874).

Schrieke, B., edit. The Effects of Western Influence on Native Civilizations in the Malay Archipelago, (Batavia, 1929).

Seton-Karr, W. S., The Marquess Cornwallis, (Oxford University Press, 1890).

Sillem, J. A., Dirk van Hogendorp, (1761-1822), (Amsterdam, 1890).

Smith, Adam, An Inquiry into the Nature and Causes of the Wealth of Nations, (London, 1778, second edition), 2 vols.

Stapel, F. W., Geschiedenis van Nederlandsch-Indië, (Amsterdam, 1930).

- edit., Geschiedenis van Nederlandsch Indië, (Amsterdam, 1938-40), Vol. V.

Teng Sioe Tjhan, De Landrente-Belasting, (Rotterdam, 1933).

Veth, P. J., Java, Geographisch, Ethnologisch, Historisch, (Haarlem, 1896-1907).

Vlekke, B. H. M., Nusantara, A History of the East Indian Archipelago, (Cambridge, Mass., 1945).

Vollenhoven, C. van, Het Adatrocht van Nederlandsch-Indië, (Leiden, 19181933).

- De Ontdekking van het Adatrecht, (Leiden 1928).

Ward, W. R., The English Land Tax in the Eightoenth Century, (Oxford University Press, 1953).

Welderen Rengers, D. W., van, The Failure of a Liberal Colonial Policy Notherlands East Indies, 1816-1830, (The Hague, 1947).

(iv) Articles \&c.:

Anon., "Private Lands", Indonesian Affairs, (August-September 1951), Vol. I, No. 8, pp. 26-9; 32-3.

Anon., "Rapport omtrent de Partikuliere Landerijen beoosten de rivier Tjimanoek", Tijdschrift voor Nijverheid en Landbouw in Noderlandsch-Indië, (Batavia, 1878), Vol. XXII, pp. 237-708.

Anon., "Stukken betreffende den Landverkoop onder het Engelsche Tusschenbestuur", Tijdschrift voor Nijverheid en Landbouw in Nederlandsch-Indië, (Batavia, 1884), Vol. XXVIII, pp. 181-208.

Anon., "Verslag Raffles Herdenking", Tijdschrift voor Indische Taal-, Land-en Volkenkunde, (Batavia, 1930), Vol. LXX, pp. 53-79. 
Bastin, J., "The Rivalry between Dirk van Hogendorp and S. C. Nederburgh", Indonesië, ('s-Gravenhage, July 1953), Vol. 7, No. 1, pp. 80-5.

- "The Chinese Estates in East Java during the British Administration", to be published in Indonesië, ('s-Gravenhage, 1954).

Dodwell, H. H., "The Straits Settlements, 1815-1863", Cambridge History of the British Empire, (Cambridge University Press, 1940), Vol. II, Chapter XVI.

Du Perron, E. - De Roos, "Correspondentie van Dirk van Hogendorp met zijn broeder Gijsbert Karel", Bijd. T.L.V., ('s-Gravenhage, 1943), Vol. 102, pp. $125-273$.

De Haan, F., "Personalia der periode van het Engelsch bestuur over Java 1811-1816", Bijd. T.L.V., ('s-Gravenhage, 1935), Vol. 92, pp. 477-681.

Hageman, J., "De Engelschen op Java", Tijdschrift voor Indische Taal-, Landon Volkonkunde, (Batavia, 1857), Vol. VI, pp. 290-458.

Ketjen, E., "Levensbericht van F. J. Rothenbühler", Verhandelingen van hot Bataviaasch Genootschap van Kunsten en Wetenschappen, (Batavia, 's Hage, 1881), Vol. XLI, pp. 71-3.

Philips, C. H., "The Secret Committee of the East India Company, 1784-1858", Bullotin of the School of Oriental Studies, (London, 1940).

Rothenbühler, F. J., "Extracten uit eene Missive van den Resident van Pekalongan, F. J. von Rothenkbühler [sic], over den staat en toestand van het comptoir Pekalongan, gericht aan Mr. Sebastiaan Cornelis Nederburgh, Commissaris-Generaal over geheel Nederlandsch-Indië en Cabo De Goede Hoop (1798)", Eindresumé, II, Bijlage II, pp. 134-146.

, "Rapport van den staat en gesteldheid van het Landschap Sourabaija; met de daarin gevonden wordende Negorijen en Dorpen, item velden, bevolking enz., enz., zoodanig als het een en ander bevonden is bij de daarvan gedanen opneem", Verhandelingen van het Bataviaasch Genootschap van Kunsten en Wetenschappen, (Batavia, 's Hage, 1881), Vol. XLI, pp. 1-70.

Wright, H: R. C., "Muntinghe's Advice to Raffles on the Land Question in Java", Bijd. T.L.V., ('s-Gravenhage, 1952), Vol. 108, pp. 220-247.

"Improvement in the East Indies", The Cambridge Journal, (Cambridge, August, 1953), Vol. VI, No. 11, pp. 688-94. 